Portland State University

PDXScholar

\title{
Silicic Volcanism at the Northern and Western Extent of the Columbia River Basalt Rhyolite Flare-up: Rhyolites of Buchanan Volcanic Complex and Dooley Mountain Volcanic Complex, Oregon
}

Adam M. Large

Portland State University

Follow this and additional works at: https://pdxscholar.library.pdx.edu/open_access_etds

Part of the Geology Commons, and the Volcanology Commons Let us know how access to this document benefits you.

\section{Recommended Citation}

Large, Adam M., "Silicic Volcanism at the Northern and Western Extent of the Columbia River Basalt Rhyolite Flare-up: Rhyolites of Buchanan Volcanic Complex and Dooley Mountain Volcanic Complex, Oregon" (2016). Dissertations and Theses. Paper 3122.

https://doi.org/10.15760/etd.3118

This Thesis is brought to you for free and open access. It has been accepted for inclusion in Dissertations and Theses by an authorized administrator of PDXScholar. Please contact us if we can make this document more accessible: pdxscholar@pdx.edu. 
Silicic Volcanism at the Northern and Western Extent of the Columbia River Basalt Rhyolite Flare-up:

Rhyolites of Buchanan Volcanic Complex and Dooley Mountain Volcanic Complex, Oregon

by

Adam M. Large

A thesis submitted in partial fulfillment of the requirements for the degree of

Master of Science

in Geology

Thesis Committee:

Martin J. Streck, Chair

Michael L. Cummings

Robert B. Perkins

Portland State University

2016 


\begin{abstract}
Two mid-Miocene (16.5-15 Ma) rhyolite volcanic centers in eastern Oregon, the Buchanan rhyolite complex and Dooley Mountain rhyolite complex, were investigated to characterize eruptive units through field and laboratory analysis. Results of petrographic and geochemical analysis add to field observations to differentiate and discriminate the eruptive units. Additionally, new geochemical data are used to correlate stratigraphically younger and older basalt and ash-flow tuff units with regional eruptive units to constrain the eruptive periods with modern Ar-Ar age dates.
\end{abstract}

Previous work at the Buchanan rhyolite complex was limited to regional mapping (Piper et al., 1939; Greene et al., 1972) and brief mention of the possibility of multiple eruptive units (Walker, 1979). Observed stratigraphic relationships and geochemical analysis were used to identify eight distinct eruptive units and create a geologic map of their distribution. Slight differences in trace element enrichment are seen in mantle normalized values of $\mathrm{Ba}, \mathrm{Sr}, \mathrm{P}$, Ti and $\mathrm{Nd}-\mathrm{Zr}-\mathrm{Hf}$ and are used to differentiate eruptive units. New geochemical analyses are used to correlate the overlying Buchanan ash-flow tuff (Brown and McLean, 1980) and two underlying mafic units to the Wildcat Creek ash-flow tuff ( 15.9 Ma, Hooper et al., 2002) and flows of the Upper Steens Basalt ( 16.57 Ma, Brueseke et al., 2007), respectively, bracketing the eruptive age of the Buchanan rhyolite complex to between 16.5 and 15.9 Ma (Brueseke et al., 2007; Hooper et al., 2002). 
The Dooley Mountain rhyolite complex was thoroughly mapped by the U.S. Geological Survey (Evans, 1992) and geochemically differentiated in a previous Portland State University M.S. thesis (Whitson, 1988); however, discrepancies between published interpretations and field observations necessitated modern geochemical data and revisions to geologic interpretations. Field and laboratory studies indicate that the Dooley Mountain rhyolite complex consists of multiple eruptive units that were effusive domes and flows with associated explosive eruptions subordinate in volume. At least four geochemically distinct eruptive units are described with variations in $\mathrm{Ba}, \mathrm{Sr}, \mathrm{Zr}$ and $\mathrm{Nb}$. Picture Gorge Basalt flows and Dinner Creek Tuff units found within the study area both overly and underlie the Dooley Mountain rhyolite complex. These stratigraphic relationships are consistent with the one existing Ar-Ar age date 15.59 $\pm 0.04 \mathrm{Ma}$ (Hess, 2014) for the Dooley rhyolite complex, bracketing the eruptive period between $\sim 16.0$ and 15.2 Ma (Streck et al., 2015; Barry et al., 2013).

The findings of this study indicate that the Buchanan rhyolite complex and the Dooley Mountain rhyolite complex are the westernmost and northernmost rhyolite complexes among the earliest (16-16.5 Ma) mid-Miocene rhyolites associated with initiation of Yellowstone hot spot related volcanism. 


\section{Acknowledgements}

I would like to thank my advisor, Dr. Martin Streck, for encouraging me to turn my love of rocks into a deeper understanding of the world around me; my committee members Dr. Michael Cummings and Dr. Robert Perkins for always providing challenges and giving students the tools to overcome them; and the entirety of the faculty and staff in the Portland State University geology department for all the assistance to students in pursuit of greater knowledge.

Without the support of my friends at PSU, working in the lab, in the field and at the computer would have been much less enjoyable; thank you Emily Hess, Bob Janzen, Courtney Savoie, Justin Sunnarborg, Phil Marcy and Erik Shafer.

Thank you to the landowners who graciously let me onto their lands to break their rocks and into their homes for a break from the heat; nobody knows where the outcrops are better than those that see them every day.

Finally, the utmost admiration, appreciation and love for my wife, Laura, whose patience and understanding allowed for many weeks in the field and months at the computer to complete this thesis. 


\section{Table of Contents}

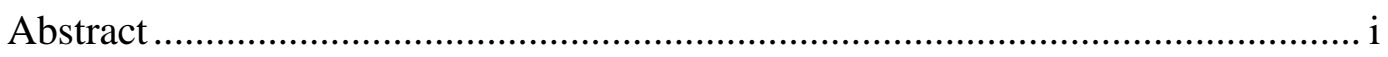

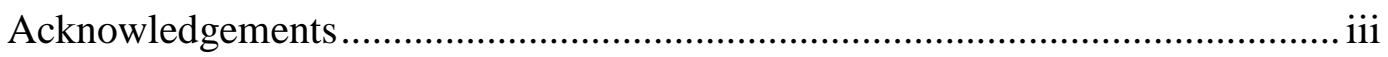

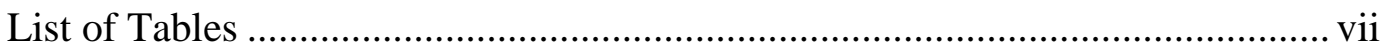

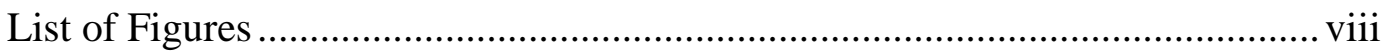

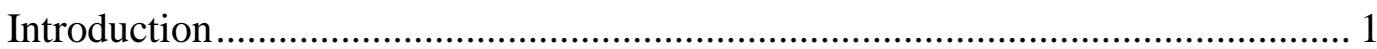

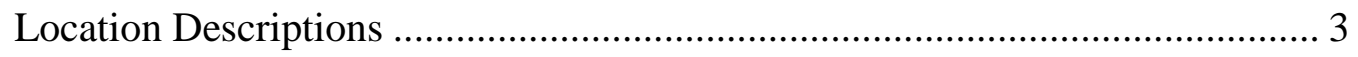

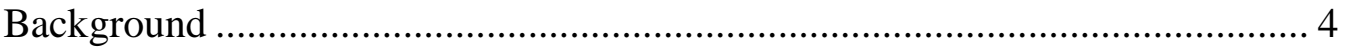

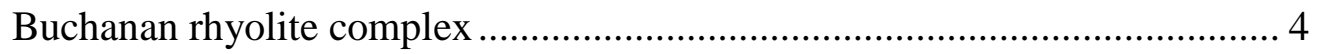

Dooley Mountain rhyolite complex.......................................................... 6

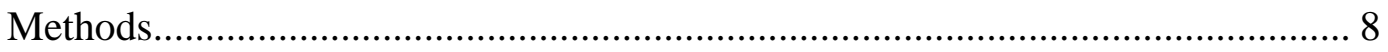

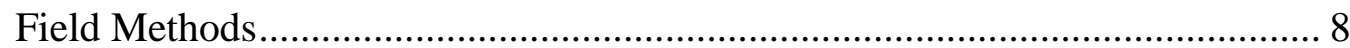

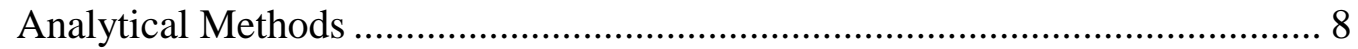

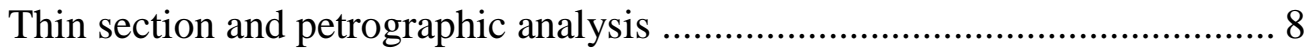

Scanning Electron Microscopy .......................................................... 9

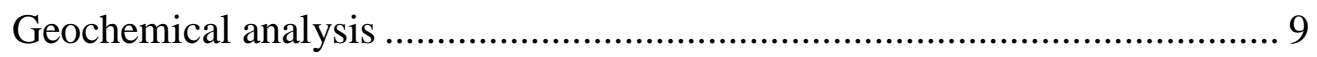

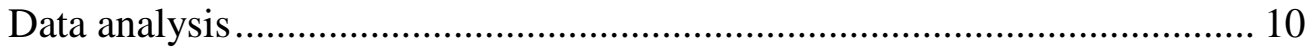

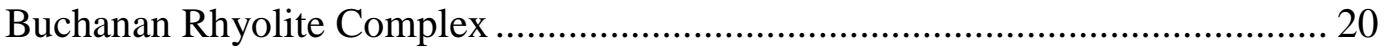

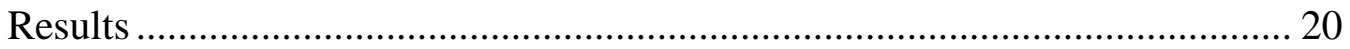


Geography and stratigraphy of units

Lithologic and petrographic characteristics of units...................................... 24

Major and trace element geochemistry...................................................... 57

Defining stratigraphic units with trace element trends .................................. 77

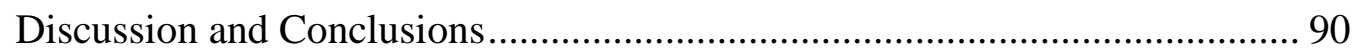

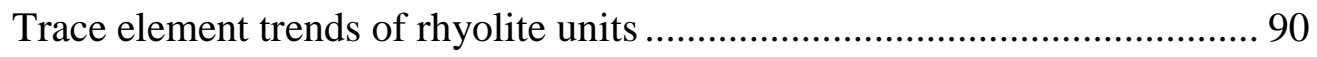

Trace element trends of basalt units ............................................................ 92

Trace element trends of Buchanan ash-flow tuff........................................... 96

Geologic map of Buchanan rhyolite complex .............................................. 98

Geologic timeline of Buchanan rhyolite complex .......................................... 99

Dooley Mountain Rhyolite Complex ................................................................. 100

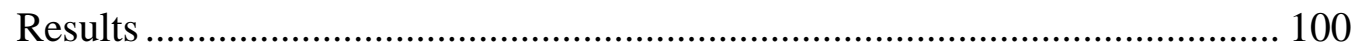

Lithologic and petrographic characteristics of units.................................... 100

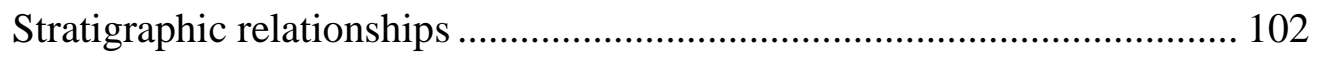

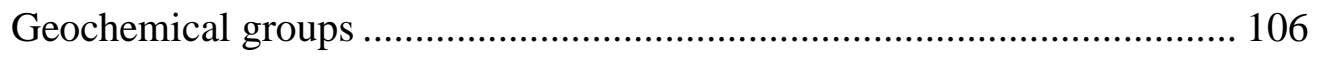

Discussion and Conclusions........................................................................ 118

Geologic descriptions and interpretations .................................................. 118

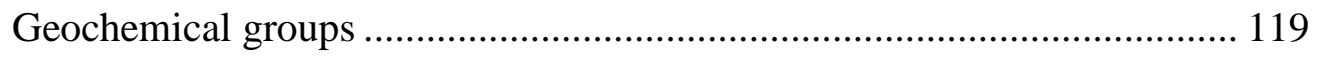

Geologic timeline of the Dooley Mountain rhyolite complex...................... 125 
References.

Appendix B-1 : Hand Sample Data.

Appendix B-2 : Petrographic Data.

Appendix B-3 : Geochemical Data

B-3a : XRF results 166

B-3b : ICP-MS results 170

B-3c : Multi-element diagrams. 174 


\section{List of Tables}

Table 1: Comparison of major elements for vitric and devitrified samples. ................... 12

Table 2: Comparison of major elements for devitrified, lower and higher $\mathrm{SiO}_{2}$ samples. 12

Table 3: Feldspar composition for unit 1A calculated from data obtained by SEM. ....... 26

Table 4: Feldspar composition for unit 1B calculated from data obtained by SEM........ 29

Table 5: Feldspar composition for unit 3B calculated from data obtained by SEM........ 38

Table 6: Feldspar composition for unit 3C calculated from data obtained by SEM........ 41

Table 7: Feldspar composition for unit 3D calculated from data obtained by SEM. ...... 44

Table 8: Feldspar composition for unit 3E calculated from data obtained by SEM........ 47

Table 9: Feldspar composition for unit 4C calculated from data obtained by SEM........ 54

Table 10: Geochemical ranges for $\mathrm{TiO}_{2}, \mathrm{FeO}^{*}(\mathrm{wt} \%)$, select trace elements (ppm) and

ratios for eruptive units at Buchanan rhyolite complex......................................... 77

Table 11: Geochemical ranges for $\mathrm{TiO} 2(\mathrm{wt} \%)$ and select trace elements (ppm) for rhyolite groups at Dooley Mountain rhyolite complex.......................................... 107

Table 12: Correlation of geochemical groups with units mapped by Evans (1992)...... 121 


\section{List of Figures}

Figure 1: Location of mid-Miocene rhyolite centers in relationship to Columbia River

Basalt, Steens Basalt and Strawberry volcanics. ......................................................... 2

Figure 2: Multi-element diagrams comparing vitric and devitrified samples................... 13

Figure 3: Multi-element diagrams of ratio values for devitrified-vitric pairs................... 14

Figure 4: Multi-element diagrams comparing lower $\mathrm{SiO}_{2}$ and higher $\mathrm{SiO}_{2}$ samples...... 16 Figure 5: Multi-element diagrams of ratio values for $\left(\right.$ Higher $\left.\mathrm{SiO}_{2}\right) /\left(\right.$ Lower $\left.\mathrm{SiO}_{2}\right)$ for

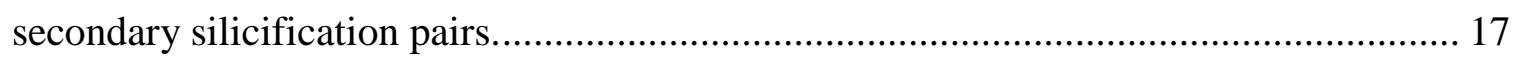

Figure 6: Multi-element diagram of ratio values for $\left(\right.$ Higher $\left.\mathrm{SiO}_{2}\right) /\left(\right.$ Lower $\left.\mathrm{SiO}_{2}\right)$ for secondary silicification within one eruptive unit....................................................... 18

Figure 7: Location map for hand samples collected at Buchanan rhyolite complex........ 20

Figure 8: Overview map of geographically separated rhyolite exposures........................ 21

Figure 9: Photograph of road cut exposure of Unit 1A. ............................................... 24

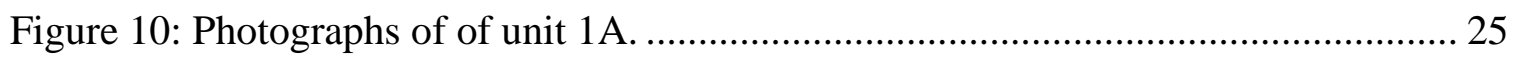

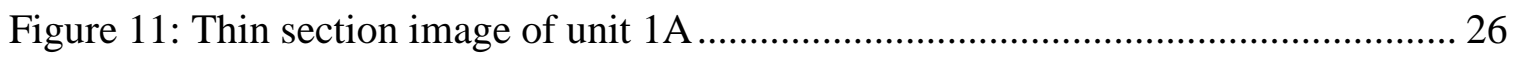

Figure 12: Feldspar ternary plot based on SEM data for Unit 1A ................................... 27

Figure 13: Photograph of unit 1B basal breccia...................................................... 28

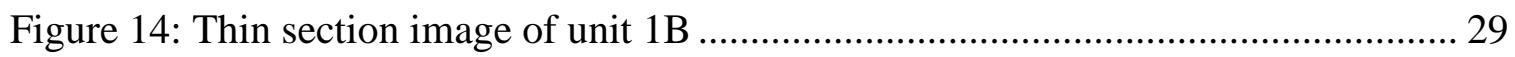

Figure 15: Feldspar ternary plot based on SEM data for Unit 1B ................................... 30

Figure 16: Photograph of excavated pit in unit 2A on Laton Point. ................................ 31

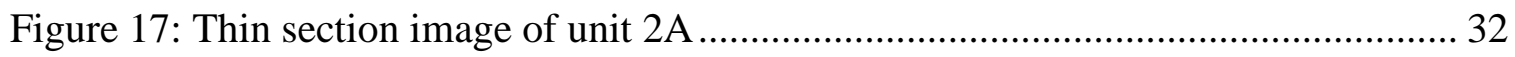

Figure 18: Photograph of unit 2B pyroclastic unit...................................................... 33 


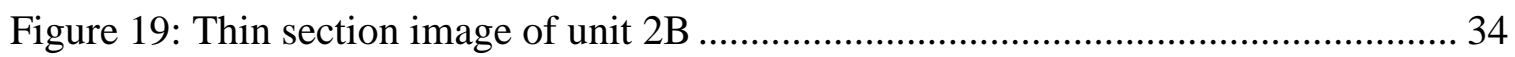

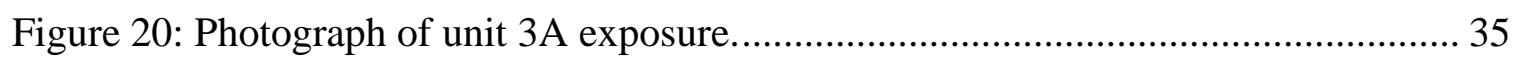

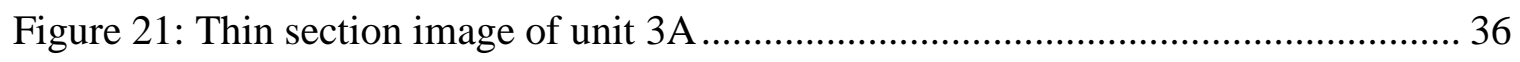

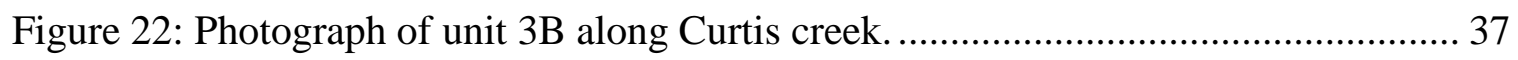

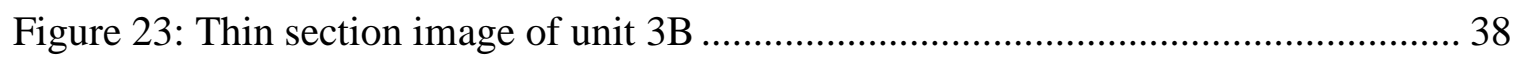

Figure 24: Feldspar ternary plot based on SEM data for Unit 3B ............................... 39

Figure 25: Photograph of unit 3C along Curtis creek ......................................... 40

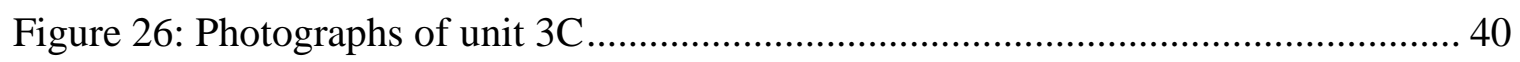

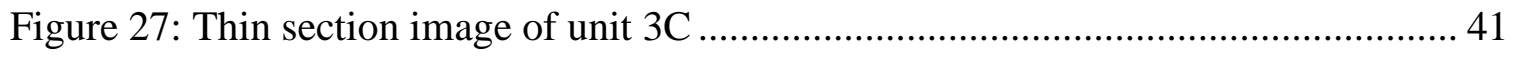

Figure 28: Feldspar ternary plot based on SEM data for Unit 3C .............................. 42

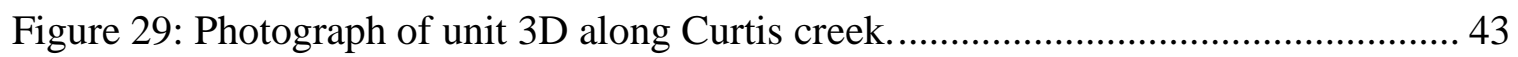

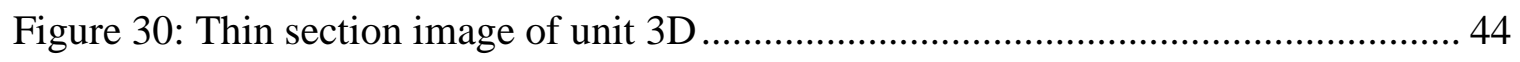

Figure 31: Feldspar ternary plot based on SEM data for Unit 3D ............................. 45

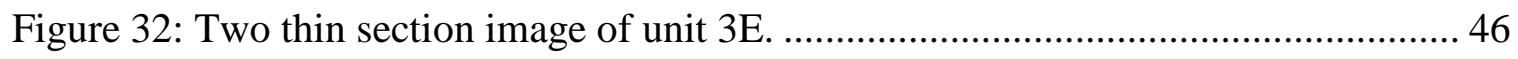

Figure 33: Feldspar ternary plot based on SEM data for Unit 3E .............................. 47

Figure 34: Photograph of unit 3F incipiently welded exposure ................................. 48

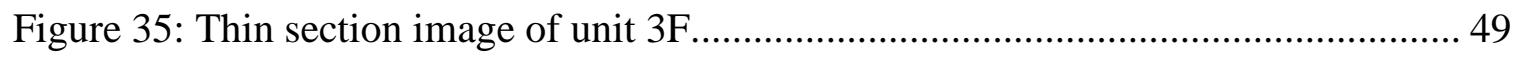

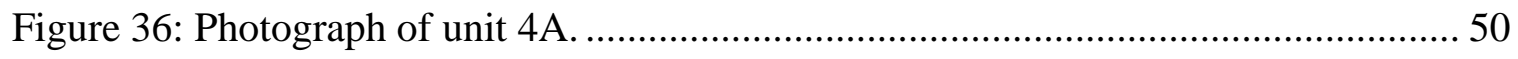

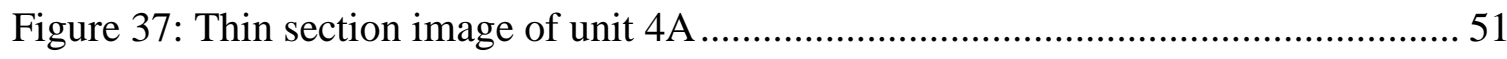

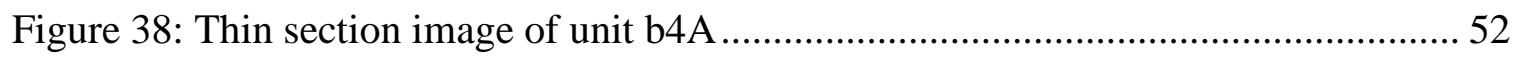

Figure 39: Photograph of unit 4C on top of ridge ............................................... 53

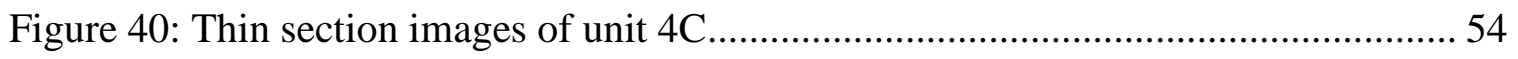


Figure 41: Feldspar ternary plot based on SEM data for Unit 4C 55

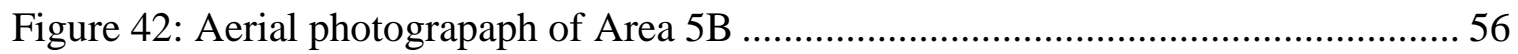

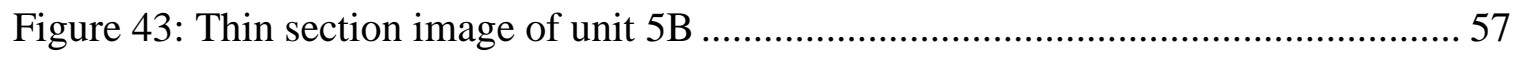

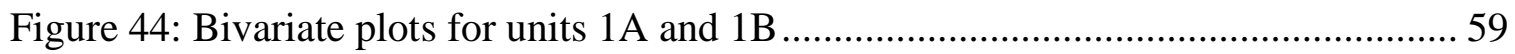

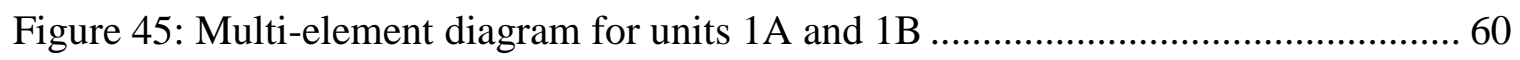

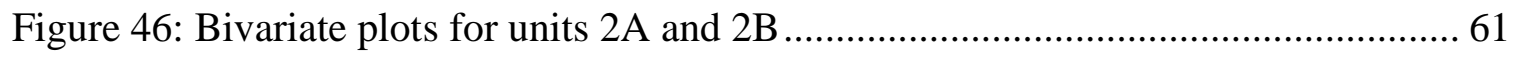

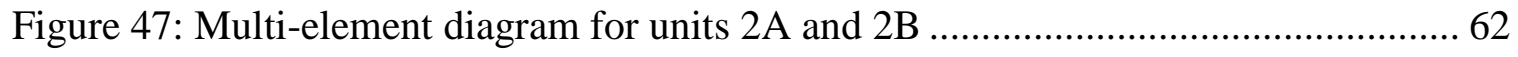

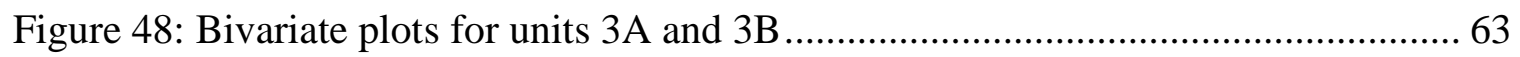

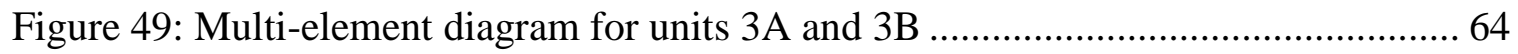

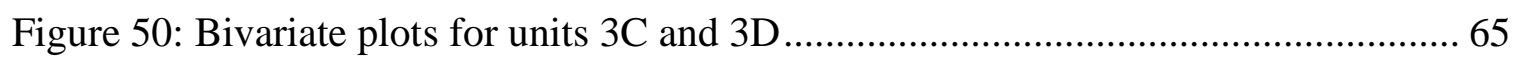

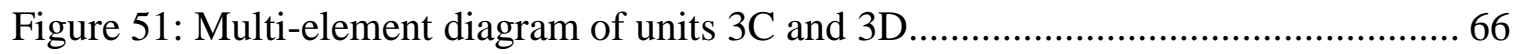

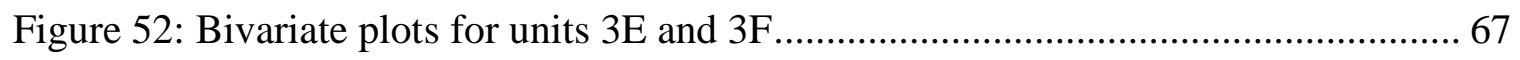

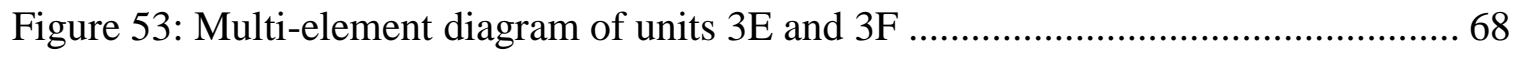

Figure 54: Multi-element diagram of all average values of area 3 units. ....................... 69

Figure 55: Part of multi-element diagram displaying average values of area 3 units...... 69

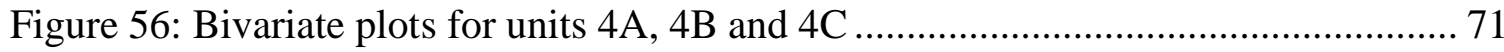

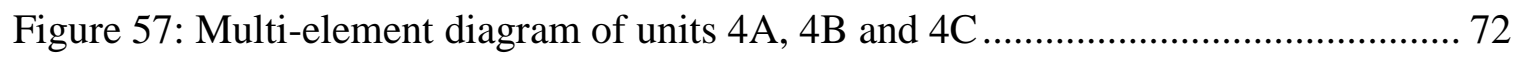

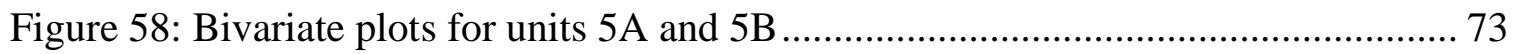

Figure 59: Multi-element diagram of units 5A, and 5B....................................... 74

Figure 60: Bivariate plots for units b3A, b4A and b4B and MS-13-SWB ..................... 75

Figure 61: Multi-element diagram of units b3A, b4A, b4B and MS-13-SWB. .............. 76

Figure 62: Multi-element diagram of Rhyolite unit R1 ....................................... 78 
Figure 63: Multi-element diagram of basaltic andesite unit Ba1 79

Figure 64: Multi-element diagram of Rhyolite unit R2 ......................................... 80

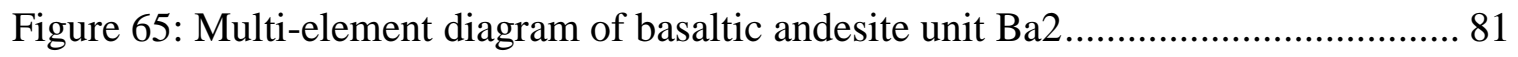

Figure 66: Multi-element diagram of Rhyolite unit R3 ........................................... 82

Figure 67: Multi-element diagram of Rhyolite unit R4 ........................................ 83

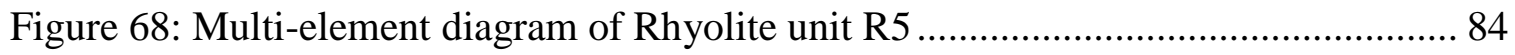

Figure 69: Multi-element diagram of Rhyolite unit R6 .......................................... 85

Figure 70: Multi-element diagram of Rhyolite unit R7 ......................................... 86

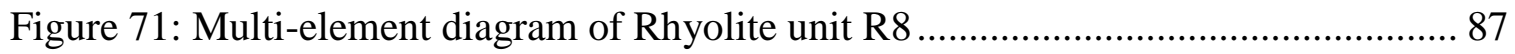

Figure 72: Multi-element diagram of Rhyolite unit RT ....................................... 88

Figure 73: Multi-element diagram of basaltic andesite unit BaU ................................ 89

Figure 74: Multi-element diagram of average Buchanan rhyolite complex rhyolite........ 90

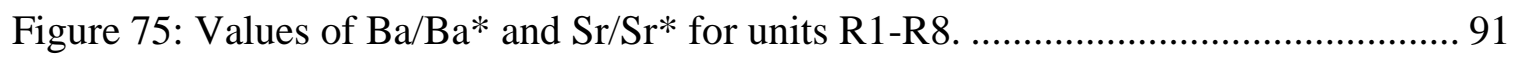

Figure 76: Multi-element diagram of mafic units $\mathrm{Ba} 1, \mathrm{Ba} 2$ and $\mathrm{BaU}$............................ 93

Figure 77: Multi-element diagram of mafic units Ba1 and Ba2 compared to average

values of Grande Ronde Basalt and Upper Steens Basalt.......................................... 94

Figure 78: Plot of $\mathrm{Na} 2 \mathrm{O}+\mathrm{K} 2 \mathrm{O}$ vs SiO2 modified from Camp (2002) . ....................... 95

Figure 79: Plot ot K2O vs. TiO2/P2O5 after Brueseke et al. (2007)............................ 95

Figure 80: Multi-element diagram of samples within unit RT overlain on unpublished

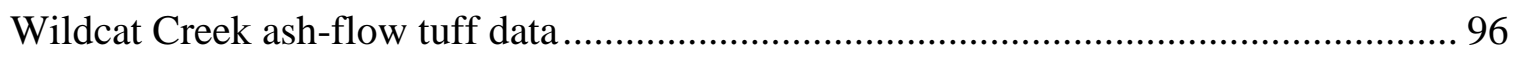

Figure 81: Geologic map of Buchanan rhyolite complex......................................... 98 
Figure 82: Location map for hand samples collected at Dooley Mountain rhyolite complex. Map modified from Evan (1992). ......................................................... 100

Figure 83: Photograph of sharp contact between brecciated aphyric unit overlying

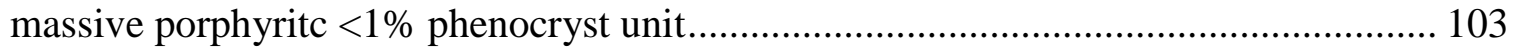

Figure 84: Photograph of cross cutting relationship of tuff dike through a massive rhyolite unit 104

Figure 85: Photograph of vitrophyric breccia overlying lapilli and ash fall and breccia 105 Figure 86: Photograph of massive rhyolite cliffs ................................................... 105

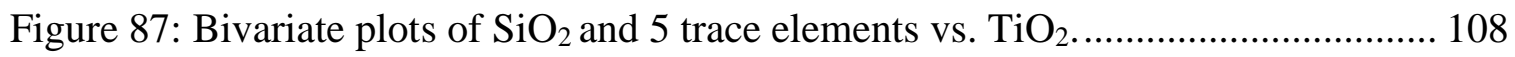
Figure 88: Multi-element diagram of average geochemical group R1 ....................... 109 Figure 89: Multi-element diagram of average geochemical group R2 ….................... 110 Figure 90: Multi-element diagram of average geochemical group R3 ….................... 111 Figure 91: Multi-element diagram of average geochemical group R4 ........................ 112 Figure 92: Bivariate plots of tuff units T1, T2 and T3, compared to Dinner Creek Tuff

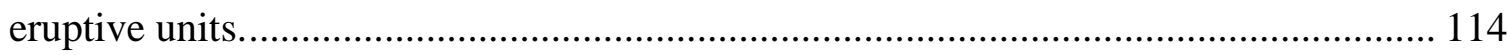
Figure 93:Multi-element diagram of average geochemical group $\mathrm{T} 1$......................... 115 Figure 94: Multi-element diagram of average geochemical group T2 ….................... 115 Figure 95: Multi-element diagram of average geochemical group T3 ........................ 116 Figure 96: Plot of Ba vs. Ta and multi-element diagram of basalt units B1-B3 in comparison to average of Imnaha basalts, Picture Gorge basalts and Grande Ronde basalts 
Figure 97: Geologic map showing locations of samples used for geochemical analysis

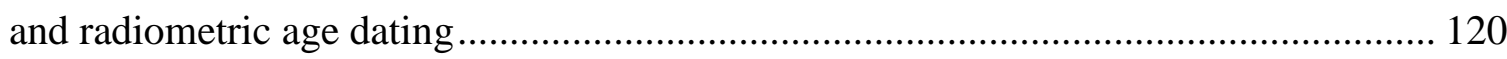

Figure 98: Correlation of geochemical groups with stratigraphy from Evans (1992)... 122 Figure 99: Geologic map showing extent of eruptive units determined by geochemical

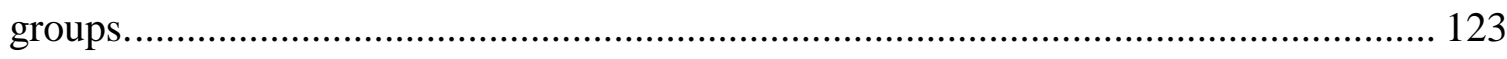

Figure 100: Geologic cross sections with eruptive units determined by geochemical analysis. 


\section{Introduction}

During the mid-Miocene, initiation of volcanism likely related to the Yellowstone hotpot resulted in the eruption of the Columbia River Basalt Group (CRBG) flood basalts, and widespread eruptions of rhyolite ash flows and lava flows in eastern Oregon, southwest Idaho and northwest Nevada (Cummings et al., 2000; Hooper et al., 2002; Brueseke et al., 2008; Shervais and Hanan, 2008; Coble and Mahood, 2012). Coble and Mahood (2012) estimate that between 16.7 and $15.0 \mathrm{Ma}, \sim 234,000 \mathrm{~km}^{3}$ of flood basalts (Steens and Columbia River basalt) and at least $\sim 3900 \mathrm{~km}^{3}$ of silicic magma were emplaced across the region (Fig. 1).

It is generally accepted that some of the earliest (16.7-16.5 Ma) rhyolite volcanism occurred near the Oregon-Idaho-Nevada border and continued in a northeastyounging trend along the Snake River Plain-Yellowstone trend (Brueseke et al., 2008; Pierce and Morgan, 2009; Coble and Mahood, 2012). However, it is not clear if there was a northward progression of rhyolite volcanism in eastern Oregon originating at these early volcanic centers or rather there was widespread coeval rhyolite volcanism across the region. Coble and Mahood (2012) describe a "rapid northward shift of the locus of mafic intrusion" that "resulted in more dispersed silicic volcanism." However, Streck et al. (2015) present age data that propose that the initiation of silicic volcanism was more widespread without a north-south trend. 


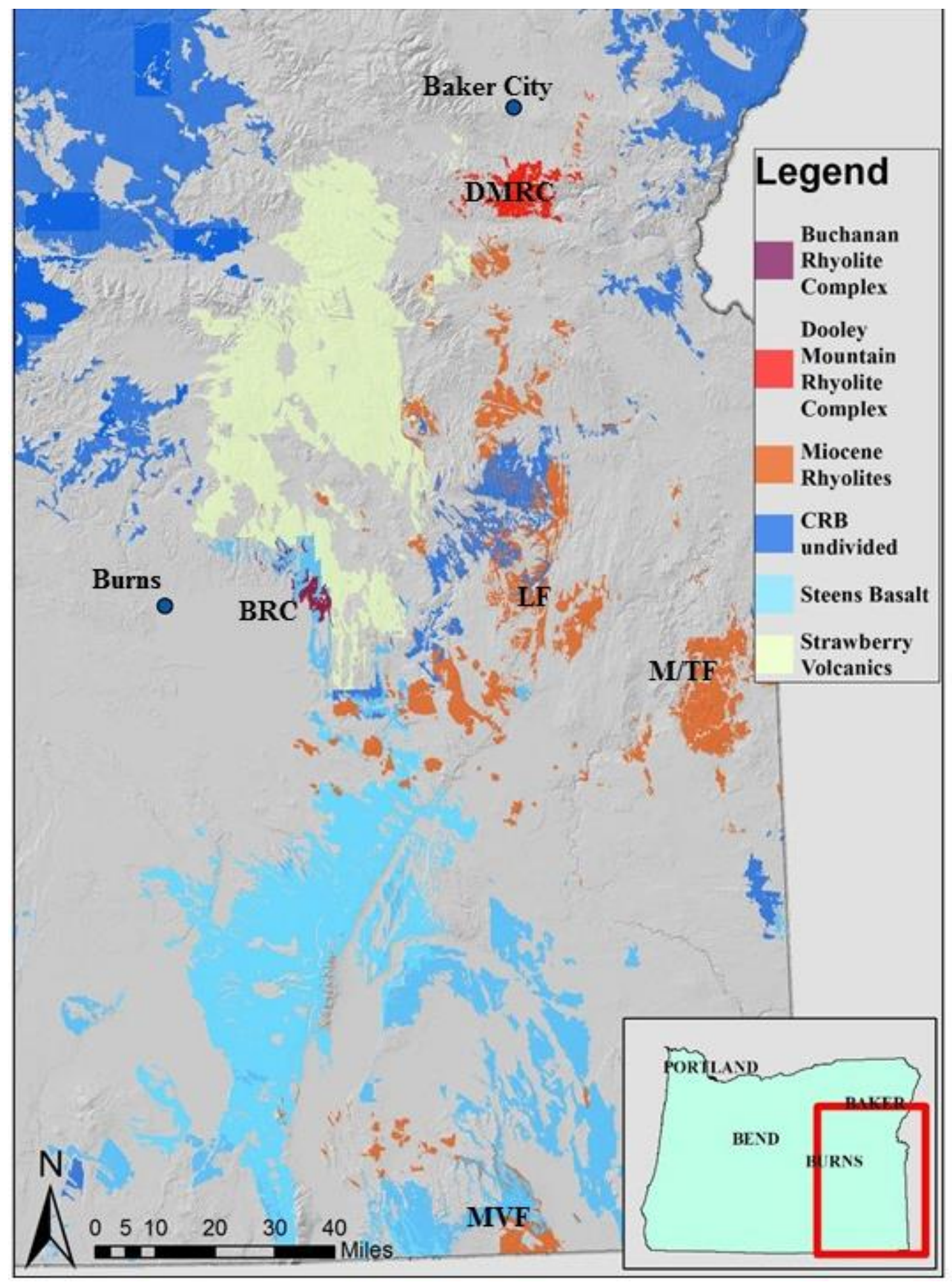

Figure 1: Location of mid-Miocene rhyolite centers in relationship to Columbia River Basalt, Steens Basalt and Strawberry volcanics. DMRC-Dooley Mountain rhyolite complex; BRC-Buchanan rhyolite complex; LF-Littlefield Rhyolite; M/TF-Mahogany Mountain/Three Fingers caldera; MVF-McDermitt volcanic field. GIS data from Oregon Geospatial Enterprise Office: http://www.oregon.gov/GEO/Pages/index.aspx 
This study intends to provide additional data regarding the timing, duration and characteristics of silicic volcanism at more distal locations in the region by focusing on two rhyolite volcanic complexes, one located at the western periphery and the other at the northern, and their stratigraphic relationships with surrounding volcanic units. To accomplish these ends we undertook field and laboratory studies.

The field component included identifying the volcanic stratigraphy within the study area, determining the extent of rhyolite eruptive units and collecting samples for laboratory analysis. In the laboratory, 48 thin sections were analyzed with petrographic microscope, whole-rock X-ray fluorescence (XRF) and inductively coupled plasma-mass spectrometry (ISP-MS) geochemical data were acquired for 71 samples (including four analyses from Hess (2014) and four unpublished analyses from Dr. Martin Streck), and phenocrysts in seven samples were analyzed with scanning electron microscope. These data allowed me to identify the characteristics of the Buchanan and Dooley Mountain volcanic complexes and put them into temporal context of rhyolite volcanism associated with the impingement of the Yellowstone hotspot.

\section{Location Descriptions}

This study focuses on two mid-Miocene rhyolite eruptive complexes. One is located in northeast Oregon and referred to by Gilluly (1937) as the "Dooley Rhyolite Breccia", Evans (1992) as the "Dooley Volcanics" and Hess (2014) as the "Dooley Mountain rhyolite". The other is located in central eastern Oregon and referred to by Piper, Robinson and Park (1939) as "older siliceous extrusive rocks", Walker (1979) as "intrusive and extrusive silicic rocks", Fiebelkorn et al. (1982) as "Buchanan dome" and 
Hess (2014) as the "Buchanan dome complex". In this study they will be referred to as the Dooley Mountain rhyolite complex and the Buchanan rhyolite complex, respectively.

Buchanan rhyolite complex is located in Harney County, Oregon, approximately 38 km east of Burns, Oregon (Fig. 1) along U.S. Route 20 (US 20) and Crane-Buchanan road south of Buchanan for approximately $13 \mathrm{~km}$. Exposures studied here are located predominantly in the Mahon Creek and Stinkingwater Pass quadrangle and to a lesser extent the Buchanan and Carson Point quadrangle. Access to the exposures from CraneBuchanan road is restricted, but possible with permission, due to private property. The Stinkingwater access road and tertiary jeep trails provide greater access across public lands to the interior of the study area.

Dooley Mountain rhyolite complex is located in Baker County, Oregon, approximately $18 \mathrm{~km}$ south of Baker City, Oregon (Fig. 1) along Oregon Route 245 (OR 245). Exposures studied here are located predominantly in the Dooley Mountain quadrangle and to a lesser extent the Brannan Gulch quadrangle. Highway 245 provides excellent access to exposures and has many road cuts along this steep and winding highway. USFS roads provide access to public lands throughout the quadrangle.

\section{Background}

\section{Buchanan rhyolite complex}

Previous work at the Buchanan rhyolite complex has been limited in scope.

Regional mapping without differentiation of eruptive units was done by the U.S. Geological Survey during water resource investigations at 1:125,000 (Piper et al., 1939), 
regional geologic mapping at 1:500,000 (Greene et al., 1972), and adapted by the State of Oregon Department of Geology and Mineral Industries from the previous two (Piper et al., 1939; Greene et al., 1972) at 1:62,500 by Brown and McLean (1980) to examine the geothermal resource potential of the Harney Basin.

Piper et al. (1939) described the units as "older siliceous extrusive rocks" to differentiate them from the younger Danforth formation and indicate that they are the only identified unit older than the Steens Basalt within the area. Walker (1979) revised the previous interpretation to include intrusive rocks and, with the aid of a K-Ar age date (14.74 $\pm 0.50 \mathrm{Ma})$ from McKee et al. (1976), determined they were "considerable younger than the Steens Basalt." Fiebelkorn et al. (1982) recalculated the previous age to 15.1 $\pm 0.50 \mathrm{Ma}$. As part of a study by Hess (2014) an Ar-Ar age date was determined on a sample collected near the location given by McKee et al. (1976) and was determined to be $16.13 \pm 0.11 \mathrm{Ma}$.

Geologic descriptions by Piper et al. (1939) and Walker (1979) are generalized and inclusive of many unrelated silicic units in the vicinity of Harney Basin. Whole rock geochemical data of the silicic units prior to this study are limited to two samples from Hess (2014).

This study focuses on identifying and differentiating eruptive units based on petrography and geochemical signatures, refine mapping of the Buchanan rhyolite complex and determining relative age dates by correlating stratigraphically younger and 
older volcanic units (e.g. local basalt and ash-flow tuff units) to better understand the timing and duration of eruptive activity.

\section{Dooley Mountain rhyolite complex}

Previous work at the Dooley Mountain rhyolite complex has included numerous mapping projects and a master's thesis focused on the geochemical stratigraphy. The area that encompasses the Dooley Mountain 7 1/2-minute quadrangle has been mapped 1:125,000 by Gilluly (1937), 1:250,000 by Brooks et al. (1976), 1:500,000 by Walker (1977) and 1:24,000 by Evans (1992). The mapping by Gilluly and Evans were products of mineral resource evaluation in the region, but do provide details about the units that provide questions that from the basis of this study.

Gilluly (1937) named the complex the Dooley rhyolite breccia and described it as "[consisting] of rhyolitic and subordinate andesitic breccias and flows." The mapping of the quadrangle put the Dooley rhyolite breccia overlying Columbia River basalts and fluvial deposits; however, a disclaimer was made that two possibilities exist to explain this:

First, that the Dooley rhyolite breccia is in part contemporaneous with the Columbia River lava of this quadrangle; second, that rhyolitic rocks of two ages, one earlier than the Columbia River lava, the other younger than the lava or contemporaneous with it, have been erroneously mapped as a single formation. The second of these possibilities seems much more likely, but the problem must be solved in the field. 
Additionally, Gilluly acknowledges that "[t]he stratigraphy of the formation is obscure, owing both to original complexities and to poor exposures brought about by the ready disintegration of the rocks composing it."

Evans (1992) renamed the complex the Dooley Volcanics to encompass the "wide range of lithology present in the unit." Evans determined there are 13 units and 16 subunits principally described as tuff (only two units and 3 sub units are described as rhyolite flows and domes) differentiated by degree of welding "and, thus, resistant to weathering." Stratigraphy was determined on a ridge-by-ridge basis matching the lithology, rock type and thickness of units.

Master's thesis research by Whitson (1988) focused on determining geochemically based stratigraphic relationships principally with neutron activation analysis (NAA) and select XRF data. He concluded, through the use of a cluster analysis scheme, that there are nine subgroups within four main groups of rhyolitic samples. The interpretive geologic map accompanying the thesis does not differentiate these groups except in cross section.

This study addresses issues brought up by the previously mentioned authors by differentiating eruptive units based on petrography and geochemical signatures, use the data to propose a revision to the mapping of the Dooley mountain quadrangle and correlate stratigraphically younger and older volcanic units (e.g. local basalt and ash-flow tuff units) to better understand the timing and duration of eruptive activity. 


\section{Methods}

\section{Field Methods}

Field mapping was conducted to identify distinct rhyolite units through stratigraphic relationships and lithologic differences. Particular attention was made to define the areal extent of exposed flows, domes, local pyroclastic units and underlying basalt flows.

Access to exposures at Buchanan rhyolite complex required private landowner permission, particularly along Crane-Buchanan road. Exposures located on public land often required crossing private land holdings, but can be hiked to from the Stinkingwater access road and several jeep trails.

Exposures at Dooley Mountain rhyolite complex are easily accessed along OR 245 and the extensive network of U.S. Forest service access roads.

Samples of rock with minimal weathering or alteration characteristics were collected for further petrographic and geochemical analysis in the laboratory. Sample coordinates were recorded with GPS. Dooley Mountain rhyolite complex hand sample descriptions and locations can be found in Appendix B-2.

\section{Analytical Methods}

\section{Thin section and petrographic analysis}

Forty eight hand samples total from both locations were selected for thin section preparation and analysis. Petrographic characteristics of samples were determined using 
plane- and cross-polarized transmitted light. Phenocryst phase, size and abundance were used to differentiate samples. Descriptions of thin sections can be found in Appendix A-1 for samples from Buchanan rhyolite complex and Appendix B-2 for Dooley Mountain rhyolite complex.

\section{Scanning Electron Microscopy}

Qualitative and quantitative data were obtained with a Zeiss Sigma VP scanning electron microscope at Portland State University through high-resolution backscatter images and spot analysis using Energy-dispersive x-ray spectroscopy (EDS). The following SEM parameters were used during analysis:

- Backscatter detector (BSD) in compositional mode

- High accelerating voltage: $15-20 \mathrm{kV}$

- Large aperture: $60 \mu \mathrm{m}$ (high current mode)

- Analytical working distance: $8.5 \mathrm{~mm}$

Spectra were obtained from the selected phenocrysts via the EDS using the same settings. Spectrums were measured at multiple points within single phenocrysts and averaged to determine the average phenocrysts composition.

\section{Geochemical analysis}

Major and trace element analysis was performed at GeoAnalytical Lab at Washington State University using XRF and ICP-MS according to the methods of Johnson et al. (1999). Analytical uncertainties were estimated using select repeat analysis of samples of this study (Appendix A-2c) and compare well with uncertainties as given in 
Johnson et al., (1999) and on the website of the Geoanalytical Lab

(http://cahnrs.wsu.edu/soe/facilities/geolab/technotes/) that states for ICP-MS analysis an analytical precision at 5\% (RSD) for Rare Earth Elements and 10\% for the remaining trace.

XRF and ICP-MS analysis results for Buchanan rhyolite complex and Dooley Mountain rhyolite complex can be found in Appendix A-2 and B-3, respectively.

\section{Data analysis}

\section{Effects of devitrification and silicification on geochemistry}

High $\mathrm{SiO}_{2}$ values (75 to $77.4 \mathrm{wt} \%$ are considered "high-silica rhyolite" (Hildreth, 1981), 12 samples from Buchanan rhyolite complex and 5 samples from Dooley Mountain rhyolite complex have $\mathrm{SiO}_{2}$ values above the upper threshold of $77.4 \mathrm{wt} \%$ ) in $\mathrm{XRF}$ analysis results indicate alteration from the original geochemical make-up. The effects of two post-emplacement processes, devitrification during cooling and silicification from external sources (e.g. hydrothermal alteration), were examined to determine which element abundances have been altered the most and which elements are useful for discriminating eruptive units.

Devitrified and vitric sample pairs collected in close proximity, from the same eruptive units, are compared to determine the effects of devitrification on the geochemical makeup of the rocks. Two pairs of samples are used to compare geochemical trends in the effect of devitrification (Table 1). The sample pair $\mathrm{B} 121 \mathrm{~B} / \mathrm{B} 121 \mathrm{~A}$ (vitric/devitrified) has $\mathrm{SiO}_{2}$ values that indicate that the differences are 
likely only from devitrification. Sample pair B147/B148 (vitric/devitrified) has $\mathrm{SiO}_{2}$ values that indicate secondary silicification also altered the geochemistry, in addition to devitrification.

Noticeable variations in major elements as a result of devitrification are seen in Table 1. Similar trends between the two sample pairs include an increase in $\mathrm{SiO}_{2}$, and $\mathrm{P}_{2} \mathrm{O}_{5}$, and decreased values of $\mathrm{FeO}^{*}, \mathrm{MnO}$ and $\mathrm{MgO}$. The sample pair B147/B148 shows greater effects of alteration than sample pair B121B/121A due to secondary silicification which is further examined in Table 2, below. 
Table 1: Comparison of major elements for vitric and devitrified samples. Positive values for \% difference indicate an increase in major element oxide abundance from vitric to devitrified samples, negative values indicate a decrease.

\begin{tabular}{lcccccc}
\hline \hline & Vitric & Devitrified & \% Difference & Vitric & Devitrified & \% Difference \\
Sample & B121B & B121A & & B147 & B148 & \\
\hline $\mathrm{SiO} 2$ & 75.71 & 76.16 & 1 & 77.04 & 82.03 & 6 \\
$\mathrm{TiO} 2$ & 0.19 & 0.20 & 4 & 0.12 & 0.15 & 23 \\
$\mathrm{Al2O} 3$ & 13.17 & 13.18 & 0 & 12.57 & 9.71 & -23 \\
$\mathrm{FeO} *$ & 1.33 & 1.00 & -25 & 1.01 & 0.91 & -11 \\
$\mathrm{MnO}$ & 0.04 & 0.01 & -70 & 0.03 & 0.01 & -82 \\
$\mathrm{MgO}$ & 0.20 & 0.10 & -51 & 0.11 & 0.05 & -56 \\
$\mathrm{CaO}$ & 1.06 & 1.07 & 1 & 0.74 & 1.01 & 37 \\
$\mathrm{Na} 2 \mathrm{O}$ & 3.78 & 3.65 & -4 & 3.53 & 2.58 & -27 \\
$\mathrm{~K} 2 \mathrm{O}$ & 4.49 & 4.60 & 2 & 4.82 & 3.53 & -27 \\
$\mathrm{P} 2 \mathrm{O} 5$ & 0.02 & 0.03 & 37 & 0.01 & 0.03 & 132 \\
\hline
\end{tabular}

Table 2: Comparison of major elements for devitrified, lower and higher $\mathrm{SiO}_{2}$ samples. Positive values for $\%$ difference indicate an increase in major element oxide abundance from vitric to devitrified samples, negative values indicate a decrease .

\begin{tabular}{lcccccc}
\hline \hline & $\begin{array}{c}\text { Lower } \mathrm{SiO} 2 \\
\text { Sample }\end{array}$ & $\begin{array}{c}\text { Higher } \mathrm{SiO} 2 \\
\text { B025B }\end{array}$ & \% Difference & $\begin{array}{c}\text { Lower SiO2 } \\
\text { B156 }\end{array}$ & $\begin{array}{c}\text { Higher SiO2 } \\
\text { B155 }\end{array}$ & \% Difference \\
$\mathrm{SiO} 2$ & 72.31 & 77.56 & 7 & 73.19 & 78.22 & 7 \\
$\mathrm{TiO} 2$ & 0.38 & 0.19 & -50 & 0.30 & 0.23 & -24 \\
$\mathrm{~A} 2 \mathrm{O} 3$ & 14.44 & 12.37 & -14 & 13.63 & 11.76 & -14 \\
$\mathrm{FeO} *$ & 2.29 & 0.82 & -64 & 2.57 & 1.17 & -55 \\
$\mathrm{MnO}$ & 0.05 & 0.01 & -75 & 0.03 & 0.01 & -61 \\
$\mathrm{MgO}$ & 0.38 & 0.06 & -83 & 0.18 & 0.02 & -91 \\
$\mathrm{CaO}$ & 1.75 & 1.02 & -41 & 0.94 & 0.78 & -17 \\
$\mathrm{Na} 2 \mathrm{O}$ & 3.63 & 3.83 & 5 & 3.90 & 3.30 & -15 \\
$\mathrm{~K} 2 \mathrm{O}$ & 4.71 & 4.10 & -13 & 5.22 & 4.48 & -14 \\
$\mathrm{P} 2 \mathrm{O} 5$ & 0.08 & 0.03 & -56 & 0.05 & 0.03 & -46 \\
\hline
\end{tabular}

The effects of secondary silicification on major element oxides are much more evident than the effects of devitrification alone. $\mathrm{SiO}_{2}$ is the only oxide that is considerably increased. $\mathrm{FeO}^{*}, \mathrm{MnO}, \mathrm{MgO}$ and $\mathrm{P}_{2} \mathrm{O}_{5}$ values decrease by more than $50 \%$ and $\mathrm{Al}_{2} \mathrm{O}_{3}$ decreases $\sim 2-3 \mathrm{wt} \%$. All other major oxides have variable decreases or 
increases. The variability of major oxide wt $\%$ make their usefulness in differentiating eruptive units questionable, however, multi-element diagrams of mantle normalized trace element abundances preserve the geochemical signature of these eruptive units.

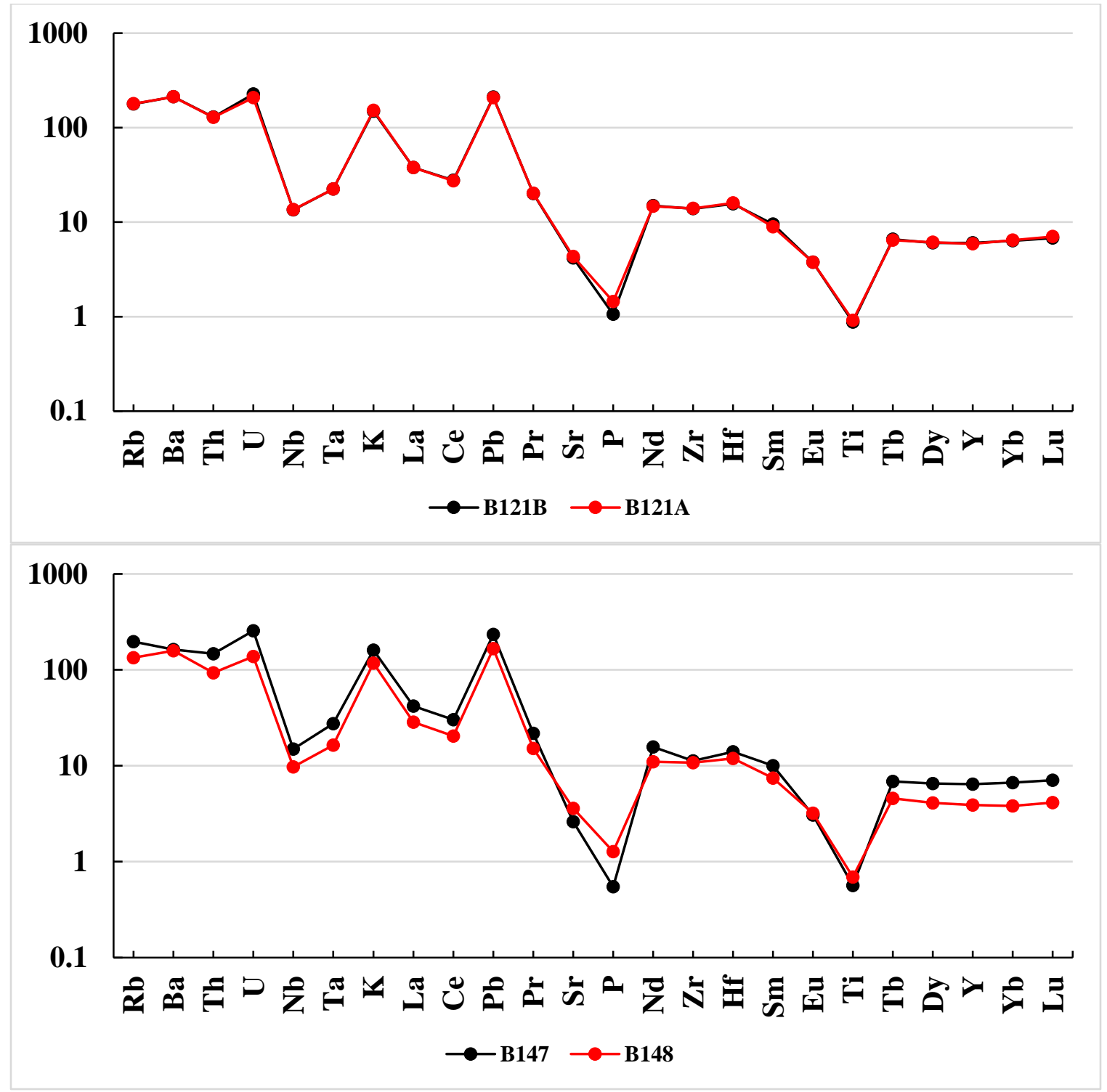

Figure 2: Multi-element diagrams comparing vitric (black) and devitrified (red) samples. Sample pairs are those found in Table 1, above. Concentrations normalized to mantle values of Sun and McDonough (1989)

Figure 2 shows that the trace element trends of eruptive units are well preserved when comparing vitric and devitrified samples. Comparison of B121B and B121A 
(Figure 2, top) shows little alteration of trace element abundances from devitrification processes alone. Comparison of B147 and B148 (Figure 2, bottom) show that the trends are similar, however the effects of secondary silicification have depleted the majority of trace element abundances.
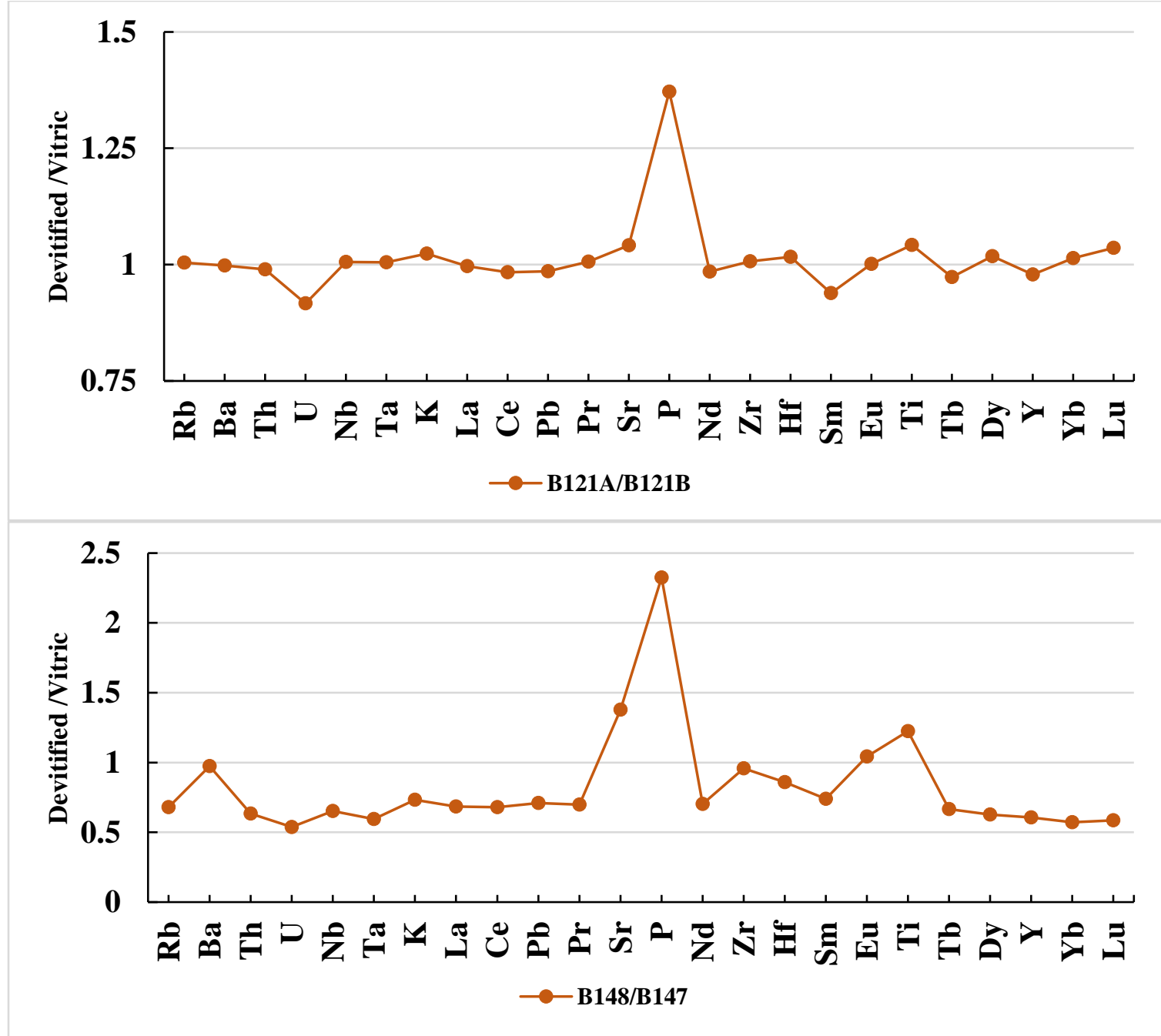

Figure 3: Multi-element diagrams of ratio values for (ppm devitrified sample) / (ppm vitric sample) for devitrified-vitric pairs. Sample pairs are those found in Table 1, above. 
Figure 3 shows the change in trace element abundances due to devitrification. Devitrification alone (Figure 3, top) shows that there are slight changes $(<10 \%)$ in abundances of all elements other than $\mathrm{P}$, which is enriched in the devitrified sample The same enrichment in P is seen in the sample pair B148/B147 (Figure 3, bottom), however the effects of secondary silicification are also seen in the depletion of the majority of trace elements. Similarities between the two include relatively unchanged $\mathrm{Ba}, \mathrm{Zr}$ and $\mathrm{Eu}$ and slight increases in $\mathrm{Sr}$ and $\mathrm{Ti}$.

Trace element trends of eruptive units are also well preserved when samples have undergone secondary silicification as seen in Figure 4, below. Similar to the trace element plot of B147 and B148 (Figure 2, bottom), there is a slight depletion of many trace elements due to secondary silicification. 


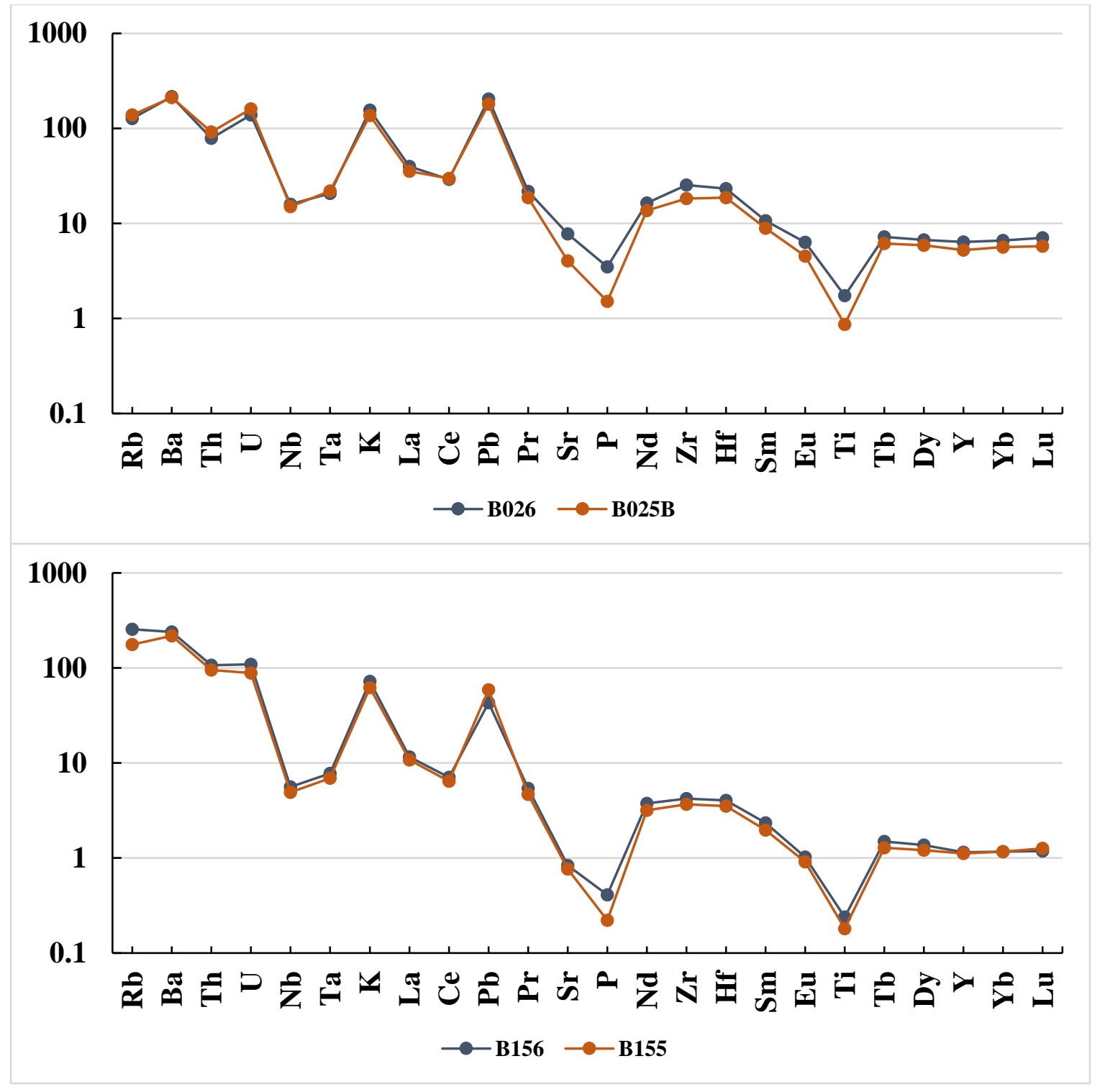

Figure 4: Multi-element diagrams comparing lower $\mathrm{SiO}_{2}$ (dark gray) and higher $\mathrm{SiO}_{2}$ (orange) samples. Sample pairs are those found in Table 2 above. Concentrations normalized to mantle values of Sun and McDonough (1989)

When comparing the change in trace element abundances due to secondary silicification (Figure 5) similarities are difficult to identify. The predominant similarity is the slight depletion of the majority of trace elements in both multi-element diagrams. Similarities in depletion of individual elements are only seen in $\mathrm{P}$ and $\mathrm{Ti}$, both being relatively more depleted than neighboring elements. 

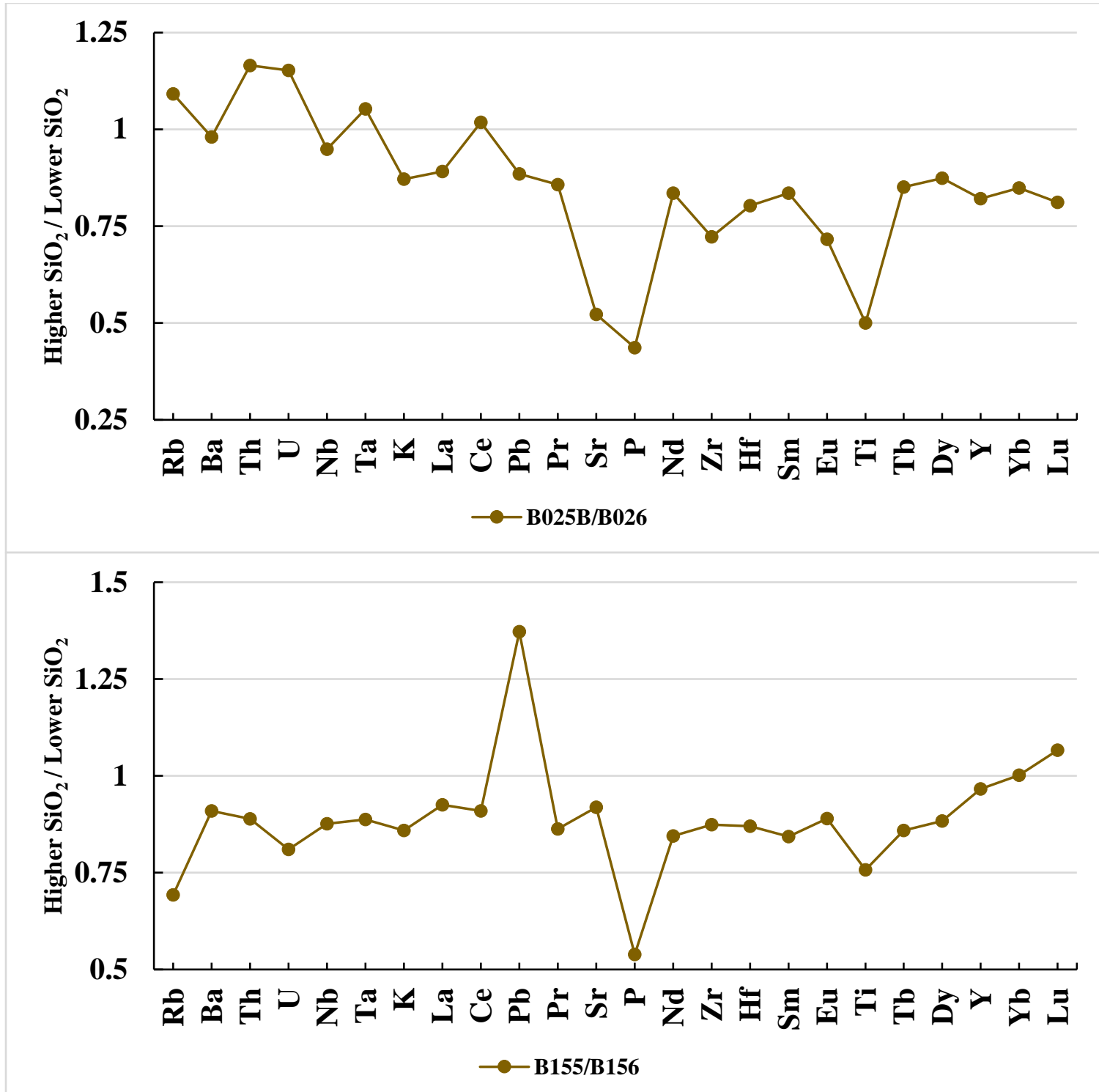

Figure 5: Multi-element diagrams of ratio values for $\left(\right.$ Higher $\left.\mathrm{SiO}_{2}\right) /\left(\right.$ Lower $\left.\mathrm{SiO}_{2}\right)$ for secondary silicification pairs. Sample pairs are those found in Table 2, above.

Although there are not many similarities in the depletion trends due to secondary silicification between eruptive units, crude trends can be identified within samples from the same eruptive unit as in Figure 6 and are unique for each eruptive unit. 


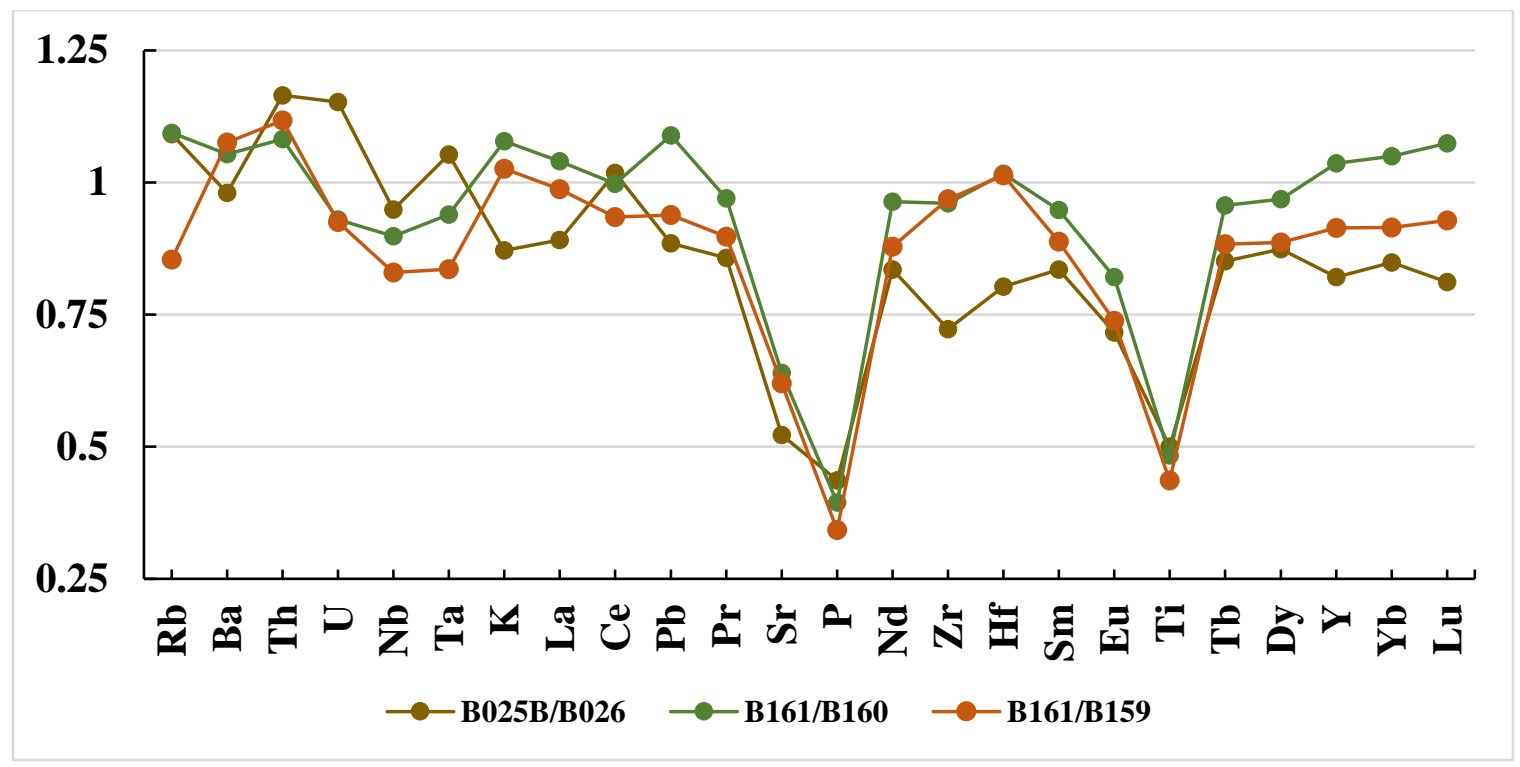

Figure 6: Multi-element diagram of ratio values for $\left(\mathrm{Higher} \mathrm{SiO}_{2}\right) /\left(\right.$ Lower $\left.\mathrm{SiO}_{2}\right)$ for secondary silicification within one eruptive unit.

The effects of devitrification and secondary silcification can be seen in both major and trace element abundances. Alteration of major element abundances make using them unreliable for differentiating eruptive units; however, because alteration trends in trace element abundances can be identified within each eruptive unit, trace elements are predominantly used to differentiate the geochemical signatures of eruptive units.

In order to account for the likelihood that chemical alteration had either enriched or depleted element abundances in the analytical results data were initially grouped and compared based on stratigraphic and petrographic correlations. Bivariate plots of select oxide weight percent ( $\mathrm{wt} \%$ ), trace element concentration and element ratios, as well as multi-element diagrams are used to differentiate and identify geochemical trends of eruptive units. Samples that were known to be stratigraphically correlative with a group of samples but had drastically different analytic results are omitted from the presented 
data. Three samples (B153, B165 and B168) were omitted but the geochemical analysis result can be found in Appendix A-2. 


\title{
Buchanan Rhyolite Complex
}

\author{
Results
}

\section{Geography and stratigraphy of units}

Over 175 hand samples from the Buchanan rhyolite complex were collected in the field. Approximate locations of all hand samples shown in Figure 7.

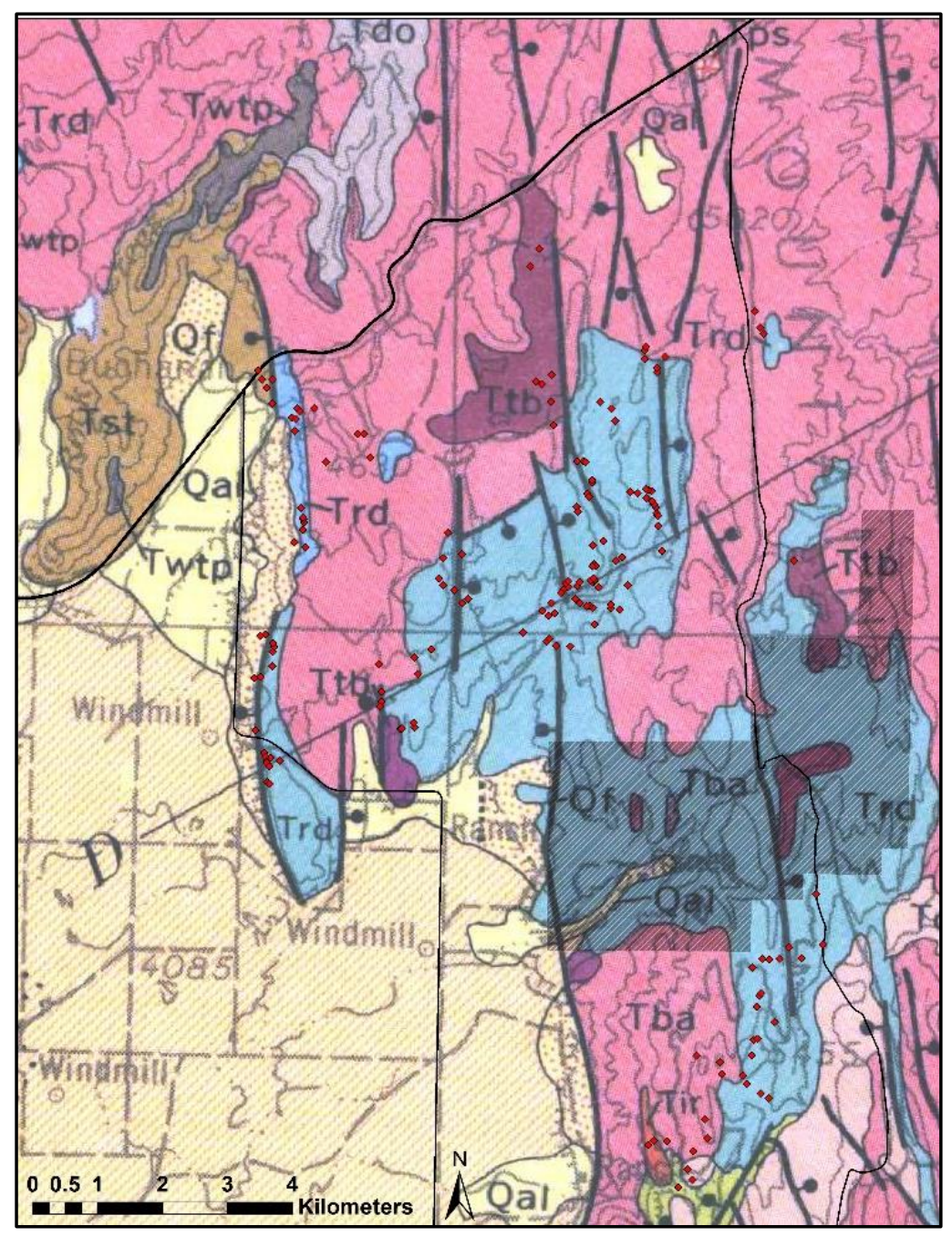

Figure 7: Location map for hand samples collected at Buchanan rhyolite complex. Map modified from Greene et al. (1972). Units identified by Green et al. (1972) that were sampled: Tba - basalt and andesite; Ttb - Ash-flow tuff near Buchanan; Trd - Rhyodacite. 
Correlating stratigraphic relationships in the field is obscured by younger basalt flows and lack of full access to units due to private property; therefore, the stratigraphy of five geographically separated areas are described initially. Latitude and longitude are given for locations where stratigraphic relationships were best observed.

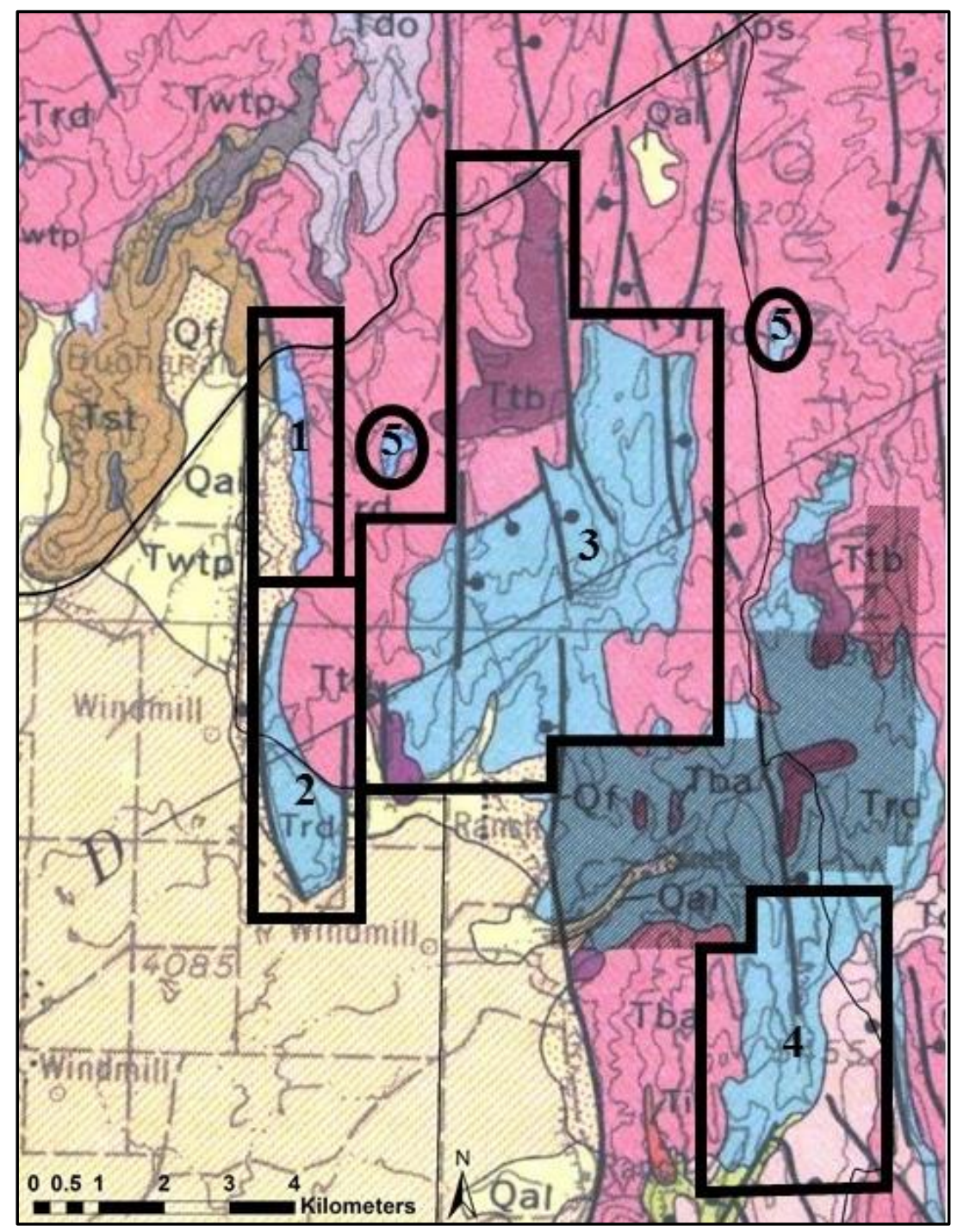

Figure 8: Overview map of geographically separated rhyolite exposures. Areas outlined with thick black border. Area 5 consists of two independent dome structures. Hashed area north of Area 4 represents private property that was not accessible. Map modified from Green et al (1972) 


\section{Area 1}

Two distinct stratigraphic units are exposed in area 1. Unit 1A is exposed along US 20 (Figure 9) in road cut (latitude $43.645^{\circ}$, longitude -118.626), forms approximately $0.75 \mathrm{~km}$ of cliffs to the east of Crane-Buchanan road south of US 20 and is inferred to be covered with colluvium from Unit 1B for approximately 2 additional km along CraneBuchanan road. Unit 1B basal breccia (Figure 13) overlies Unit 1A at latitude 43.638, longitude -118.619 , and is exposed as rim rock east of Crane-Buchanan road for approximately $2 \mathrm{~km}$.

\section{Area 2}

Two distinct stratigraphic units are exposed in area 2. Unit 2A in exposed along Crane-Buchanan road as cliff (latitude 43.602, longitude -118.626) and outcrops from approximately $3 \mathrm{~km}$ south of US 20 to the southern end of Laton Point. Unit 2B overlies 2A, exposed in outcrop (latitude 43.606, longitude -18.622) from approximately $3 \mathrm{~km}$ south of US 20 along Crane-Buchanan road and in a pit dug on the top of Laton point (Figure 16).

\section{Area 3}

Five stratigraphically distinct rhyolite units (3A-3E), one rhyolitic tuff (3F) and one mafic unit, are exposed in area 3. Unit 3A is exposed at and around latitude 43.597, longitude -118.595. Mafic unit b3A is exposed in a small outcrop at latitude 43.616, longitude -118.650 along Curtis Creek. Unit 3B is well exposed northwest of Unit 3A at latitude 43.614, longitude -118.565 along Curtis Creek. Unit 3C overlies unit 3B at latitude 43.616, longitude -118.561 and Unit 3A at latitude 43.611, longitude -118.568. 
Unit 3D overlies Unit 3C at latitude 43.619, longitude -118.561 and was best exposed in outcrop at latitude 43.626, longitude -118.549. Unit 3E overlies Unit 3D at latitude 43.628, longitude -118.551. Tuff of Buchanan, unit 3F, overlies Unit 3B at latitude 43.645, longitude -118.570 and form the ridge continuing north approximately $3 \mathrm{~km}$ to Hwy 20.

\section{Area 4}

Three distinct rhyolite flow units and two distinct basaltic andesite units are exposed in Area 4. Rhyolite unit 4A is exposed at and around latitude 43.565, longitude 118.520. Rhyolite unit 4B is found between two basaltic andesite flows, b4A at latitude 43.565, longitude -118.528 and b4B at latitude 43.563, longitude -118.529 and overlies unit 4A. Unit 4C, at latitude 43.558, longitude -118.529 , forms the ridge and hills that continue south-southwest for approximately $1 \mathrm{~km}$. Previous mapping by Greene et al. (1972) indicate that rhyolite flows in Area 4 are exposed continuously to Area 3; however, lack of permission to access private property hindered confirmation and correlation at this time, yet acquired chemical and mineralogical data are instructive in discussing unit correlations between both areas (see below).

\section{Area 5}

Two geographically independent dome-like exposures, 5A and 5B, are located in the Northwest and Northeast of the mapped area, respectively. Unit 5A is located at latitude 43.633 , longitude -118.605 approximately $1.5 \mathrm{~km}$ south-southeast of the Buchanan Springs rest area along Hwy 20. Unit 5B is located at latitude 43.651, 
longitude -118.530, approximately $4.5 \mathrm{~km}$ south of Hwy 20 along Stinkingwater access road near Steer Ridge Reservoir.

\section{Lithologic and petrographic characteristics of units}

Macroscopic (outcrop and hand sample characteristics) and microscopic (mineral phase abundance, physical attributes, chemical composition (as determined by SEM)) characteristics of units are presented to aid in unit identification both in the field and with microscopy. Units are referred to with the nomenclature established based on geography and stratigraphy.

\section{Area 1}

\section{Unit 1A}

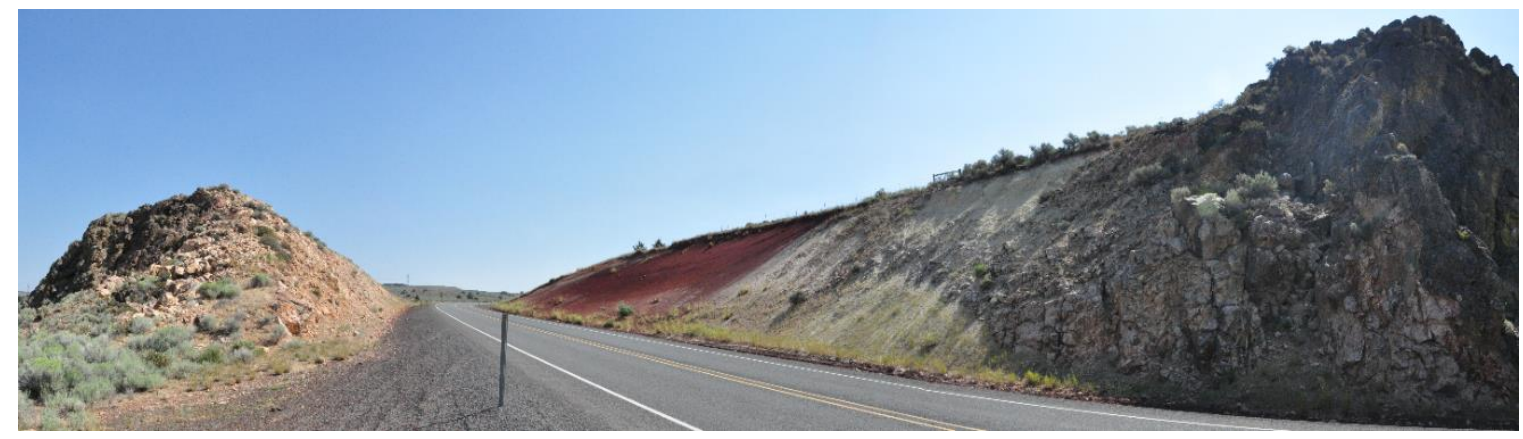

Figure 9: Photograph of road cut exposure of Unit 1A. View facing northeast along US 20.

Macroscopic characteristics: Exposed in road cut $\sim 15 \mathrm{~m}$ tall near the intersection of US 20 and Crane-Buchanan road and $\sim 40 \mathrm{~m}$ tall cliffs to the south for $\sim 900 \mathrm{~m}$. Contact alteration during the emplacement of overlying basalt is evident along the road cut exposure (Figure 9 and 10).

Hand samples are porphyritic with color ranging from white to medium gray. Phenocrysts include rounded quartz 1-2 $\mathrm{mm}$ and euhedral feldspar up to $3 \mathrm{~mm}$. 
Phenocryst abundance is approximately $10 \%$. Samples collected toward the top of the unit have pervasive secondary silicification in the form of amorphous silica within fractures.

Microscopic characteristics: Phenocryst abundance is $\sim 10 \%$ consisting of $\sim 7 \%$ alkali feldspar and 3\% quartz. Additional petrographic characteristics are noted in Appendix A-1, samples B005(p) and B005.
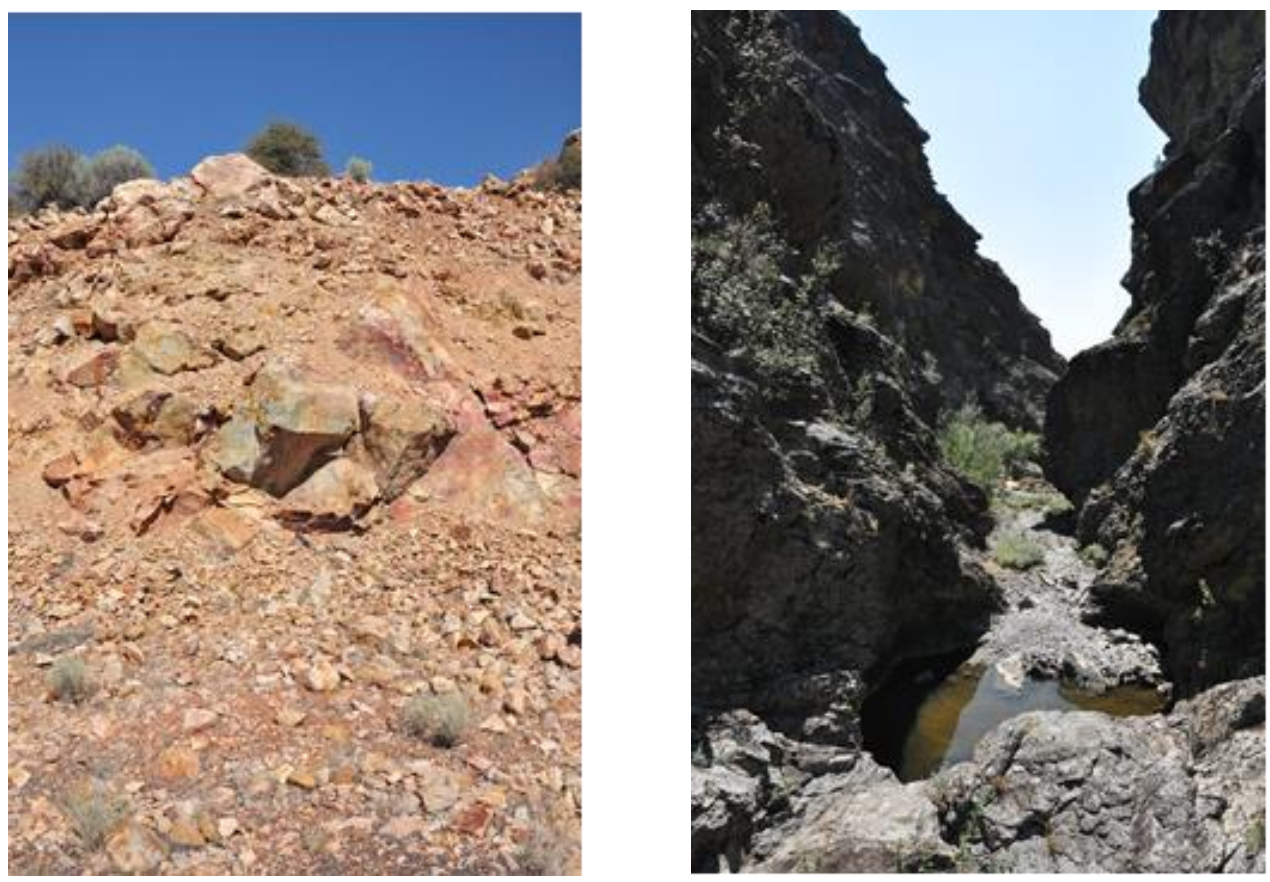

Figure 10: Photographs of of unit 1A. (Left) Road cut outcrop showing contact alteration from overlying basalt. View facing north on highway 20. (Right) Stream cut slot canyon through unit 1A, view facing southwest. 


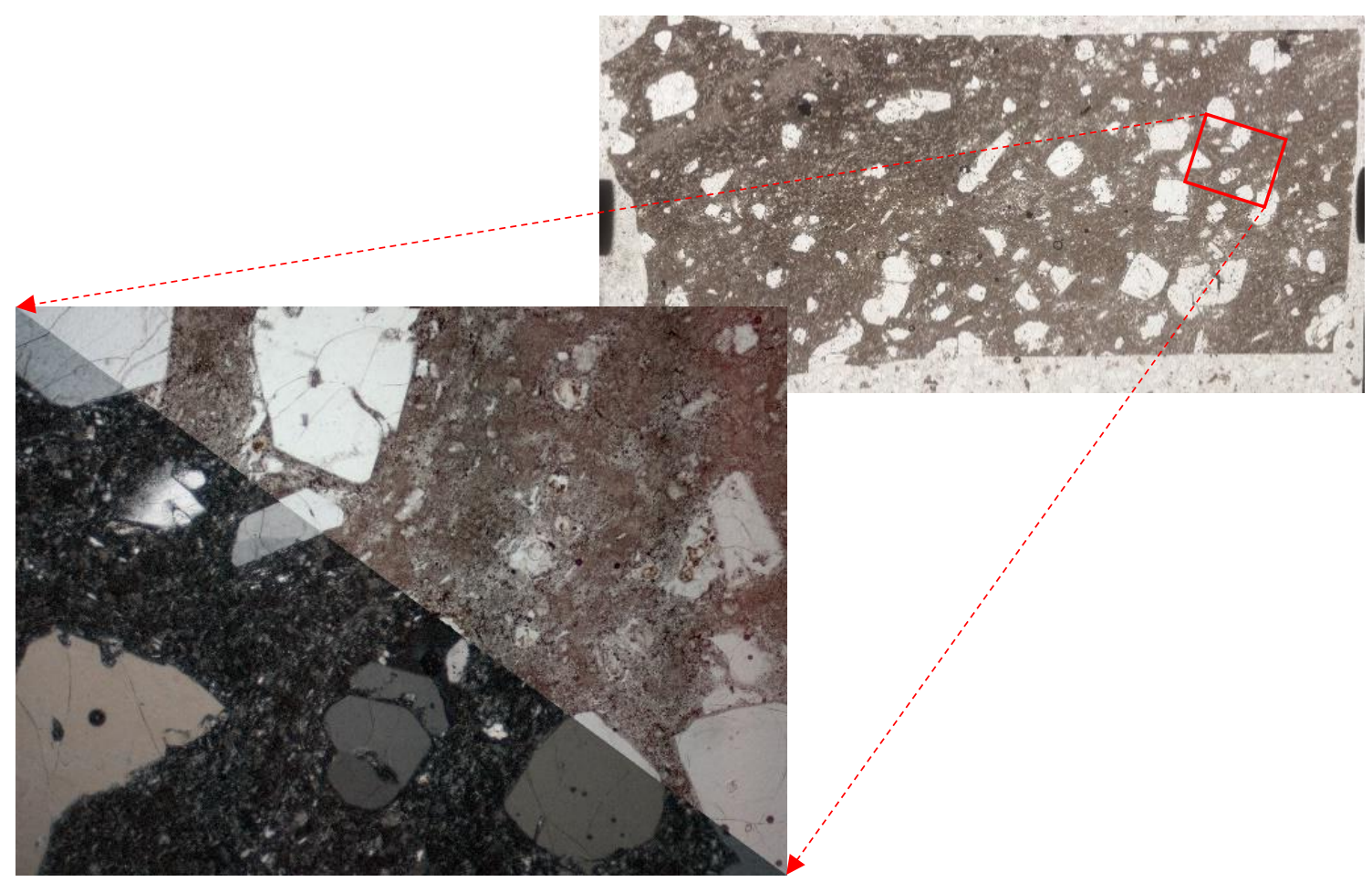

Figure 11: Thin section image of unit 1A (upper right) with highlighted area shown in image under transmitted and cross-polarized light (lower left).

SEM analysis indicates that the alkali feldspar is sanidine (Figure 12). A mineral inclusion in a quartz phenocryst was also analyzed by SEM and was determined to be An 40 plagioclase (Table 3 and Figure 12).

Table 3: Feldspar composition for unit 1A calculated from data obtained by SEM.

\begin{tabular}{|c|c|c|c|c|c|c|c|}
\hline $\begin{array}{l}\text { B005 feldspar } \\
\text { population, } n=8\end{array}$ & Or & $A b$ & An & $\begin{array}{l}\text { B005 feldspar } \\
\text { inclusion, } n=1\end{array}$ & Or & $A b$ & An \\
\hline Mean & 49 & 51 & 0 & Mean & 9 & 51 & 40 \\
\hline Minimum & 48 & 49 & 0 & Minimum & 9 & 51 & 40 \\
\hline Maximum & 51 & 52 & 0 & Maximum & 9 & 51 & 40 \\
\hline $\begin{array}{l}\text { Standard } \\
\text { Deviation }\end{array}$ & 0.97 & 0.97 & 0.00 & $\begin{array}{l}\text { Standard } \\
\text { Deviation }\end{array}$ & 0.00 & 0.00 & 0.00 \\
\hline
\end{tabular}




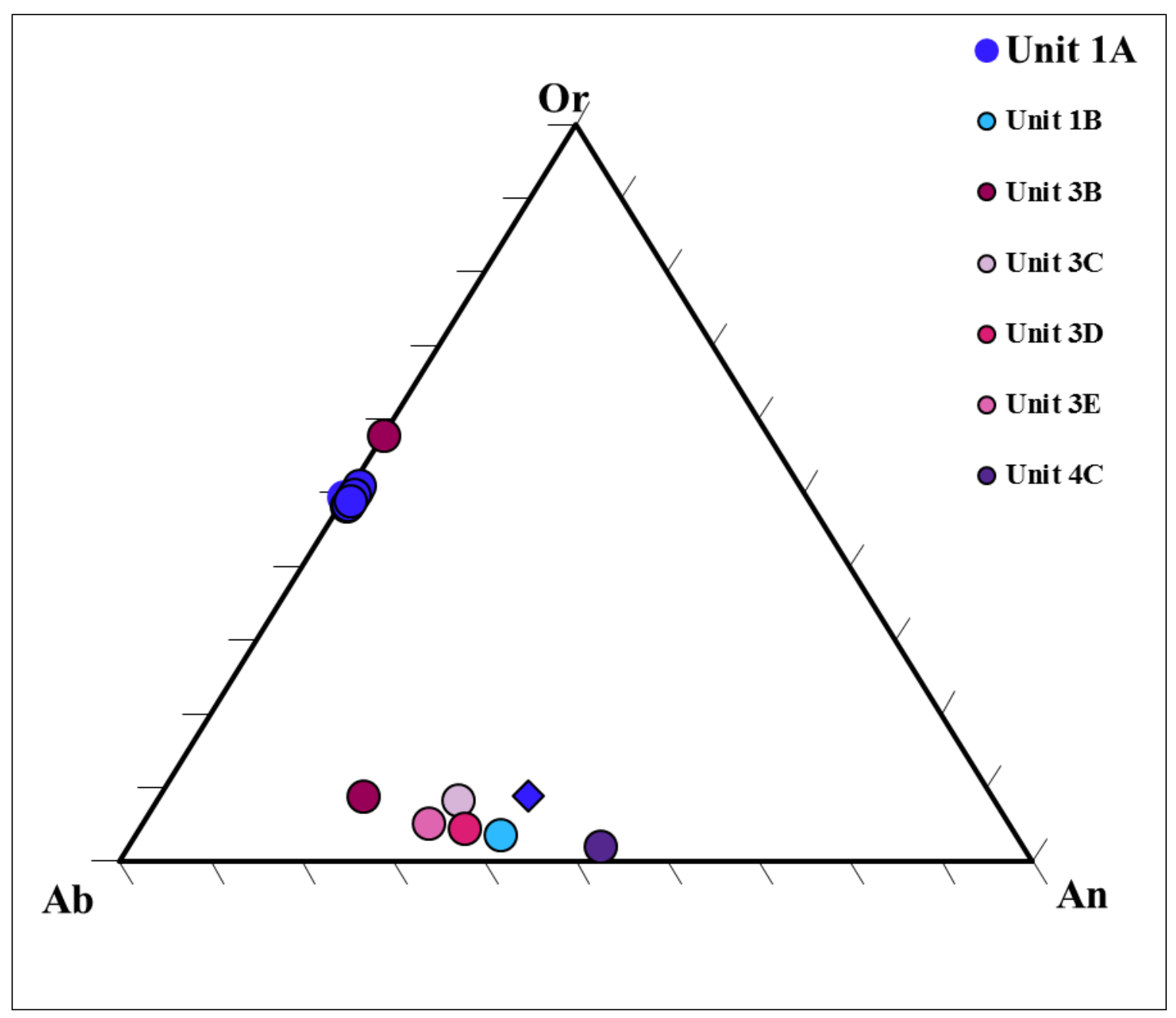

Figure 12: Feldspar ternary plot based on SEM data showing all analysis results for Unit 1A (dark blue) and averages for all other rhyolite units analyzed. Dark blue diamond is analysis results for a feldspar inclusion within a quartz phenocryst in Unit $1 \mathrm{~A}$.

\section{Unit 1B}

Macroscopic characteristics: Exposed overlying unit 1A as cap rock cliffs for approximately $2 \mathrm{~km}$ along Crane-Buchanan road. Basal breccia is exposed at latitude 43.639, longitude -118.619. Hand samples are porphyritic with color ranging from medium gray to dark gray with some pale pink in the basal breccia (Figure 13). Phenocrysts include euhedral feldspar up to $3 \mathrm{~mm}$ and altered pyroxene $\sim 1 \mathrm{~mm}$ (Figure 14). Phenocryst abundance is approximately $15 \%$. Samples collected toward the top of 
the unit have pervasive secondary silicification in the form of amorphous silica within fractures.

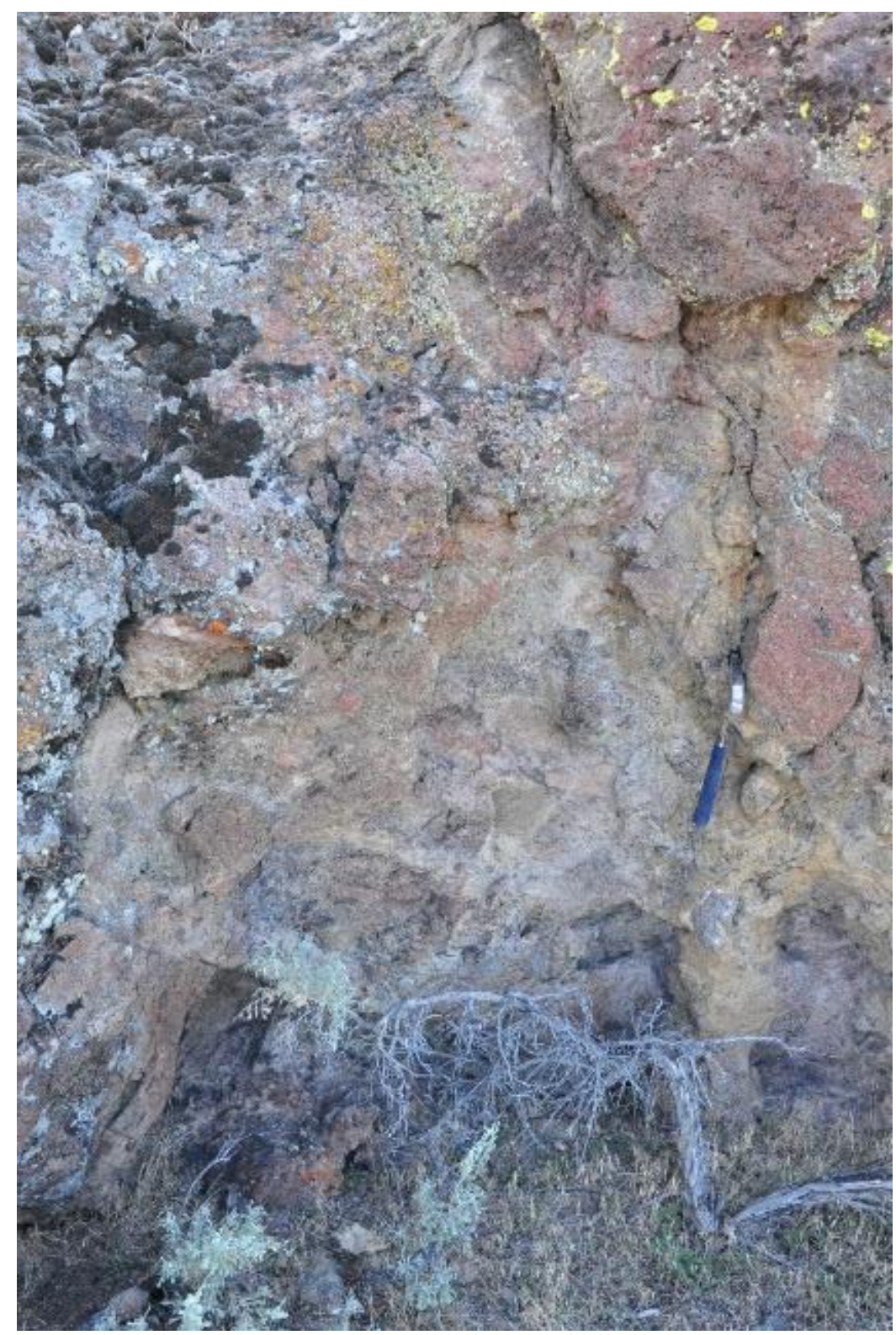

Figure 13: Photograph of unit 1B basal breccia (hammer for scale) 
Microscopic characteristics: Phenocryst abundance is $~ 15 \%$ consisting of $\sim 14 \%$ plagioclase feldspar and 1\% clinopyroxene (Figure 14). Additional petrographic characteristics are noted in Appendix A-1 for samples B010(p) and B010.

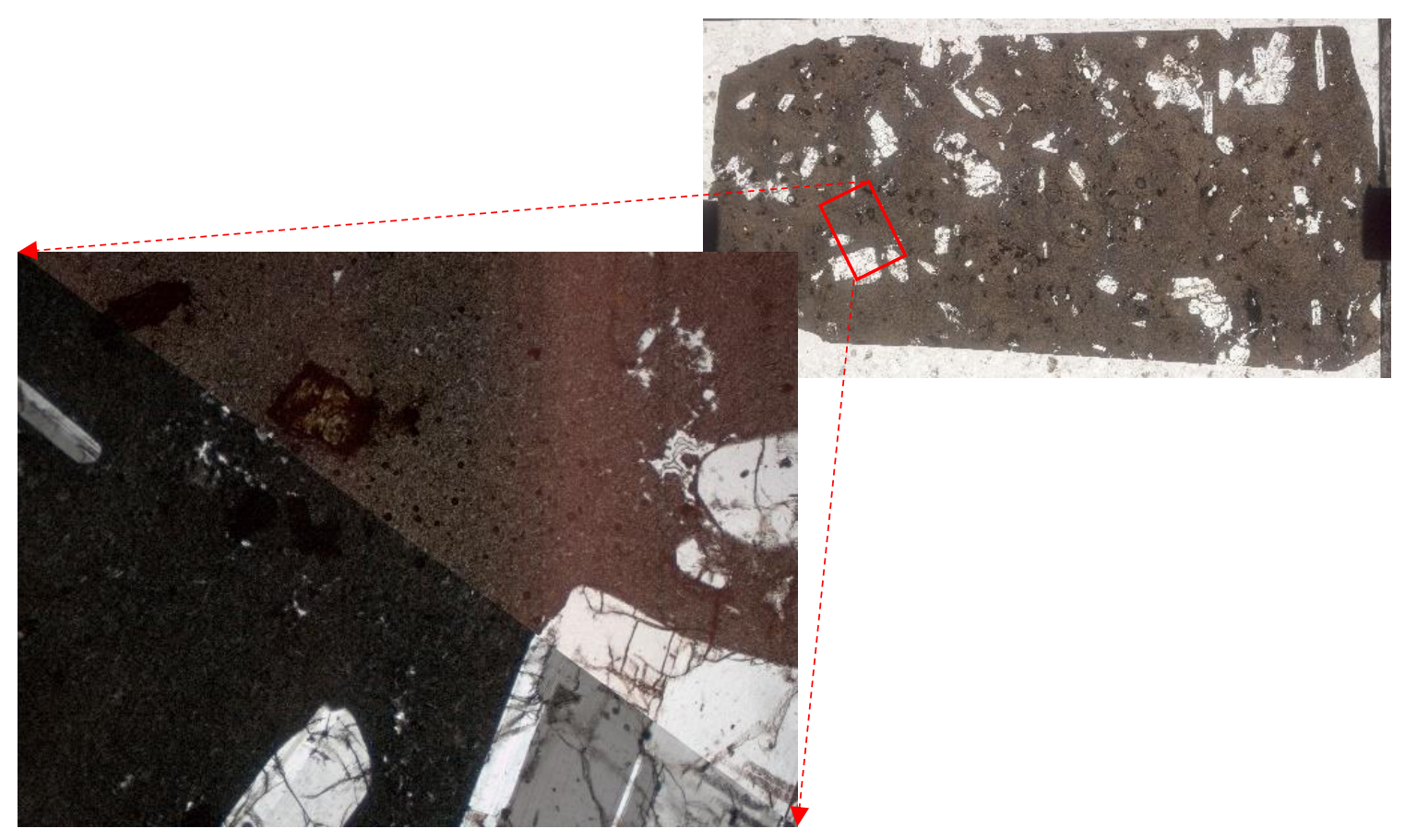

Figure 14: Thin section image of unit 1B (upper right) with highlighted area shown in image under transmitted and cross-polarized light (lower left).

SEM results indicate that the feldspar are $\mathrm{An}_{40}$ plagioclase (Table 4 and Figure $15)$.

Table 4: Feldspar composition for unit 1B calculated from data obtained by SEM.

\begin{tabular}{cccc}
\hline $\begin{array}{c}\text { B010 feldspar } \\
\text { population, } \mathrm{n}=8\end{array}$ & Or & $\mathrm{Ab}$ & $\mathrm{An}$ \\
\hline \hline Mean & 4 & 56 & 40 \\
Minimum & 3 & 53 & 35 \\
Maximum & 4 & 61 & 44 \\
Standard & & & \\
Deviation & 0.49 & 2.28 & 2.72 \\
\hline
\end{tabular}




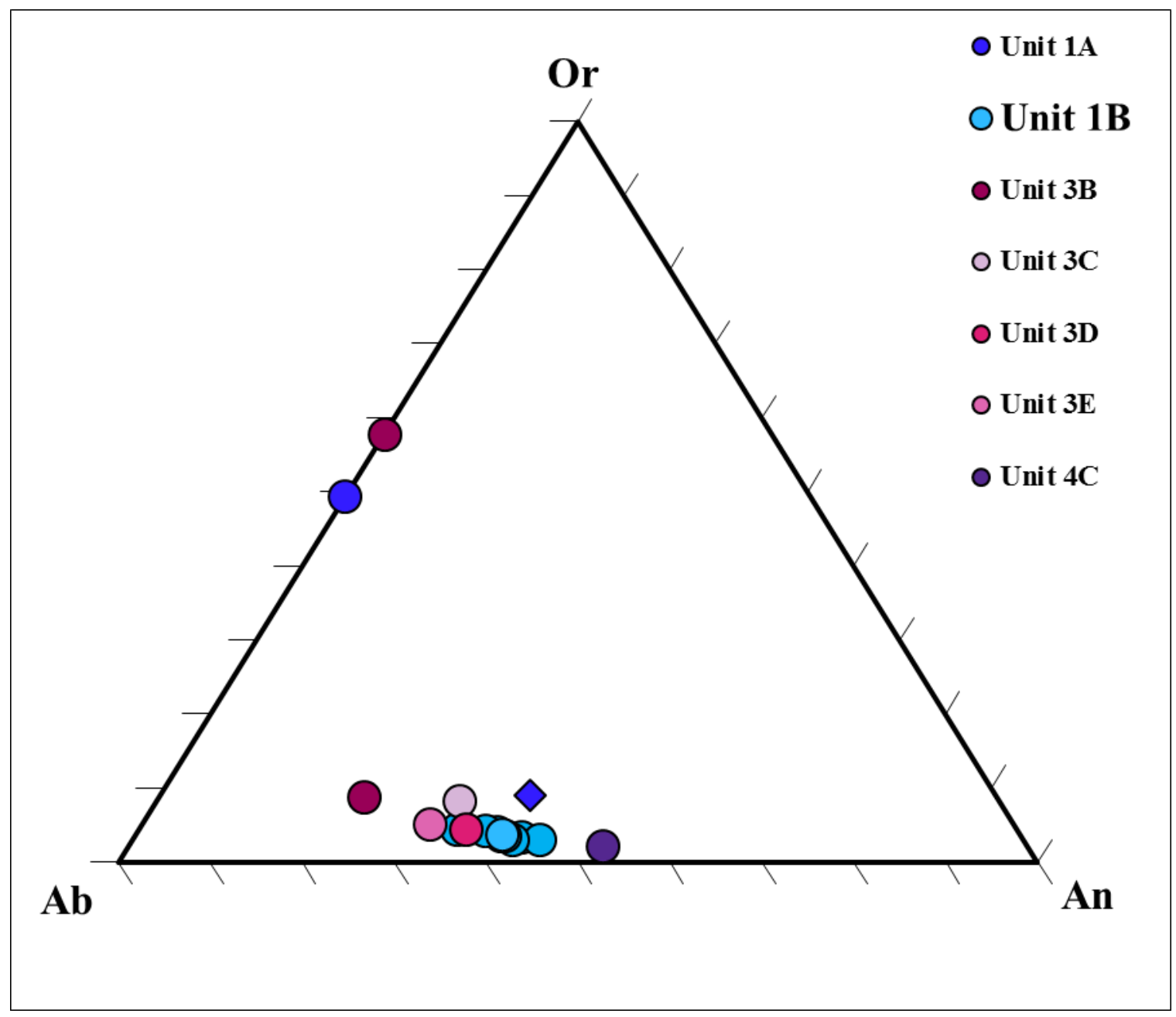

Figure 15: Feldspar ternary plot based on SEM data showing all analysis results for Unit 1B (light blue) and averages for all other rhyolite units analyzed.

\section{Area 2:}

\section{Unit 2A}

Macroscopic characteristics: Exposed as $\sim 10$ m cliffs. Lithologies range from vitric to devitrified. The transition zone between vitric and fully devitrified has large spherulites that have been infilled and replaced with secondary silica forming thundereggs. Numerous excavation pits are dug to access the thundereggs exposing the devitrification transition of this unit. 


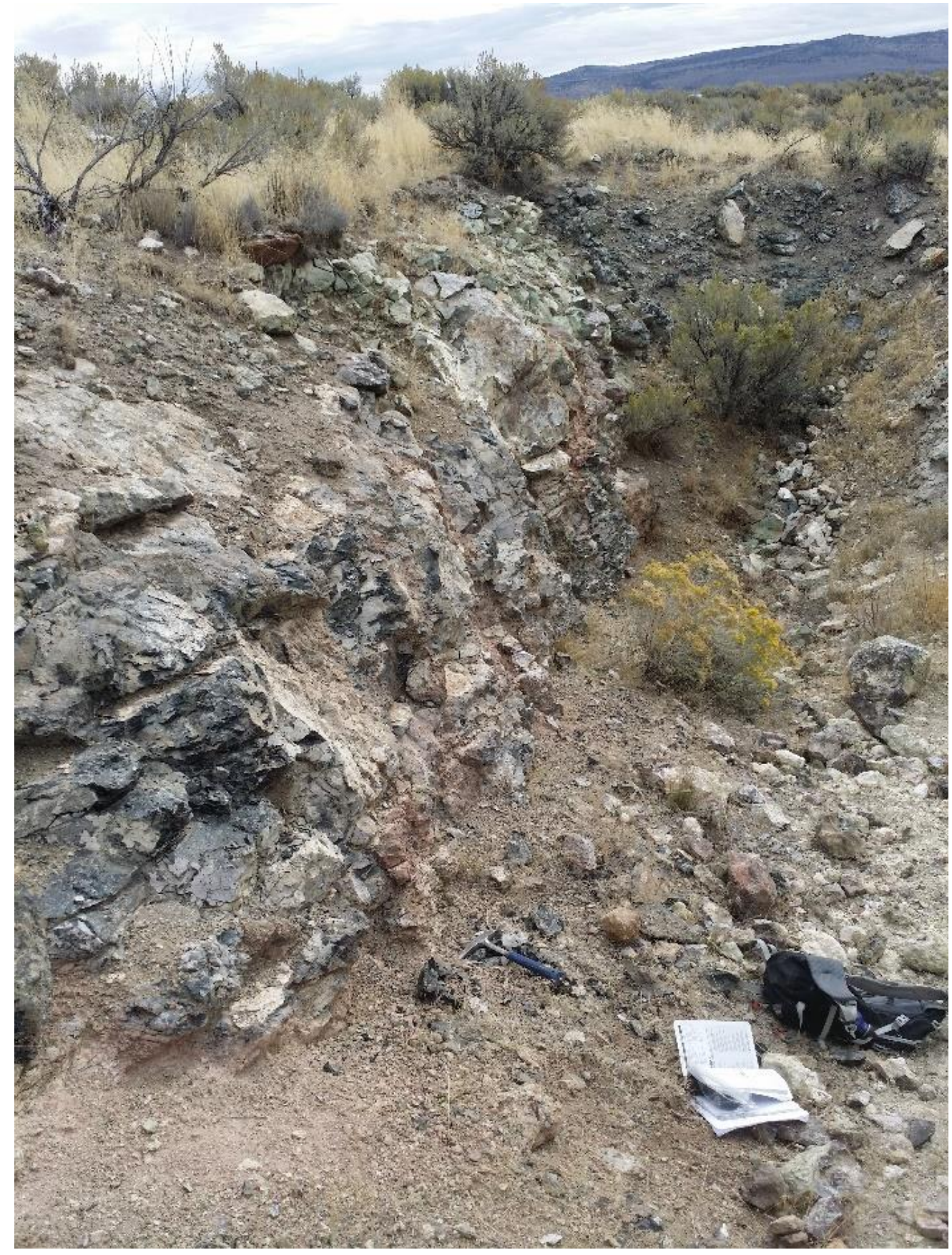

Figure 16: Photograph of excavated pit in unit 2A on Laton Point.

Hand samples are porphyritic with devitrified sample color ranging from

moderate pink to dusky red, vitric samples are medium dark gray. Flow banding is

present in the majority of samples. Phenocrysts include euhedral blocky feldspar up to 3 
$\mathrm{mm}$ and lathes up to $10 \mathrm{~mm}$ long. Phenocryst abundance is variable between $\sim 1 \%$ and $10 \%$ and no apparent within-flow zoning of phenocryst abundance.

Microscopic characteristics: Phenocryst abundance is variable between $1 \%$ and 10\%. Phenocrysts are plagioclase feldspar. Additional petrographic characteristics are noted in Appendix A-1 for sample B175.

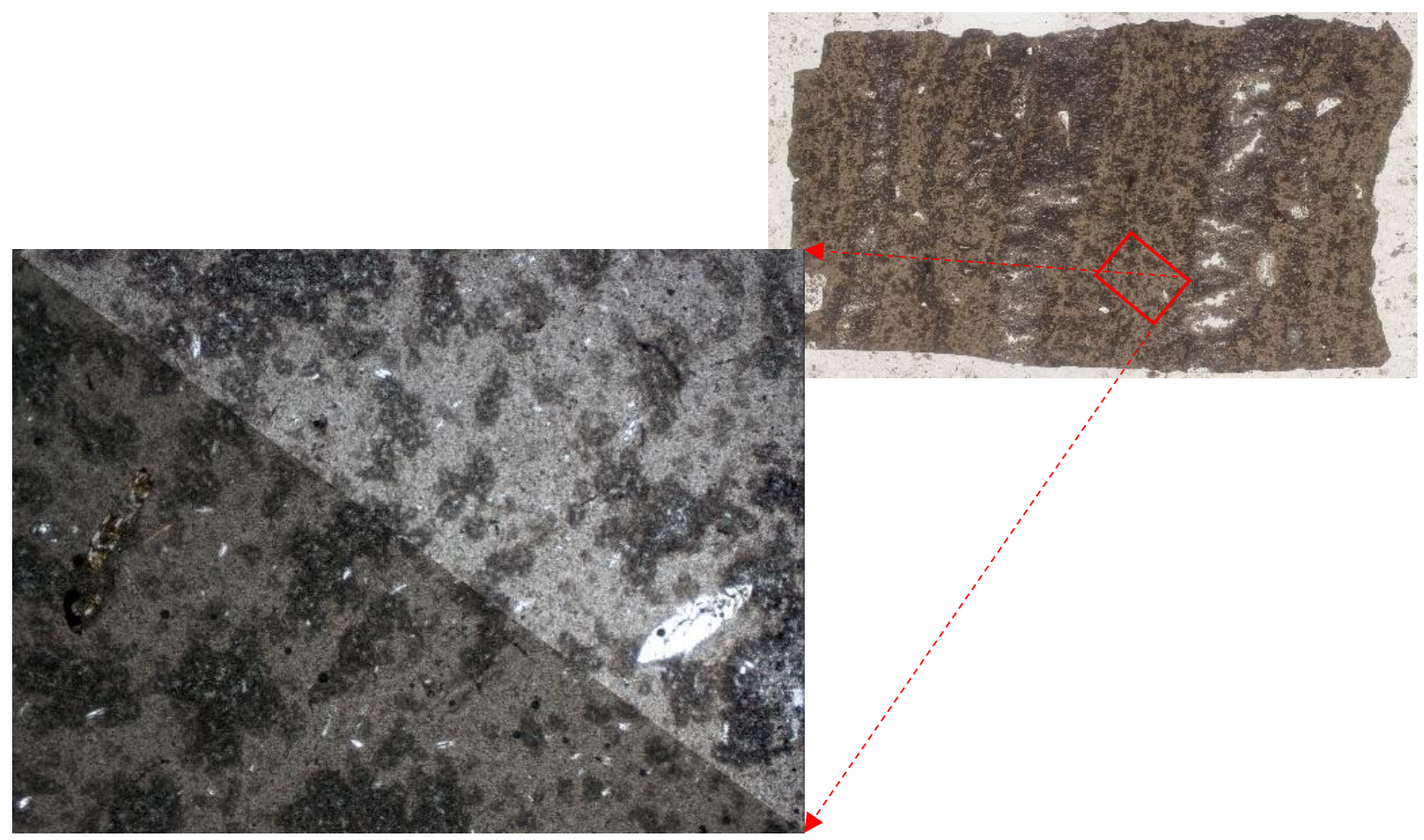

Figure 17: Thin section image of unit 2A (upper right) with highlighted area shown in image under transmitted and cross-polarized light (lower left). The portion of the sample prepared for thin section has a low phenocryst compared to other handsamples from this unit.

\section{Unit 2B}

Macroscopic characteristics: Exposed overlying unit 2A as whitish bedrock outcrops up to $2 \mathrm{~m}$ tall. Unit $2 \mathrm{~B}$ is a pyroclastic fall deposit composed of lapilli and ash sized, rarely block sized, mostly juvenile particles best observed in excavation pits on Laton Point (Figure 18). Northernmost exposures contain more and larger lithic fragments of what looks like clasts derived from unit 2A (dusky red color). Some lithic 
clasts are up to $0.5 \mathrm{~m}$ near latitude 43.606 , longitude -118.622 (inferred as possibly near eruption source) and quickly grade to smaller clasts further from this point.

Hand samples collected near a potential eruption source contain numerous angular lithic fragments of unit $2 \mathrm{~A}$ in matrix support of fine-grained angular white fragments. Color ranges from yellowish gray to greenish gray where more silicified near the potential eruption source. Phenocrysts in white pyroclasts and ash and lapilli fall are euhedral feldspar up to $1 \mathrm{~mm}$. Phenocryst abundance is approximately $2 \%$.
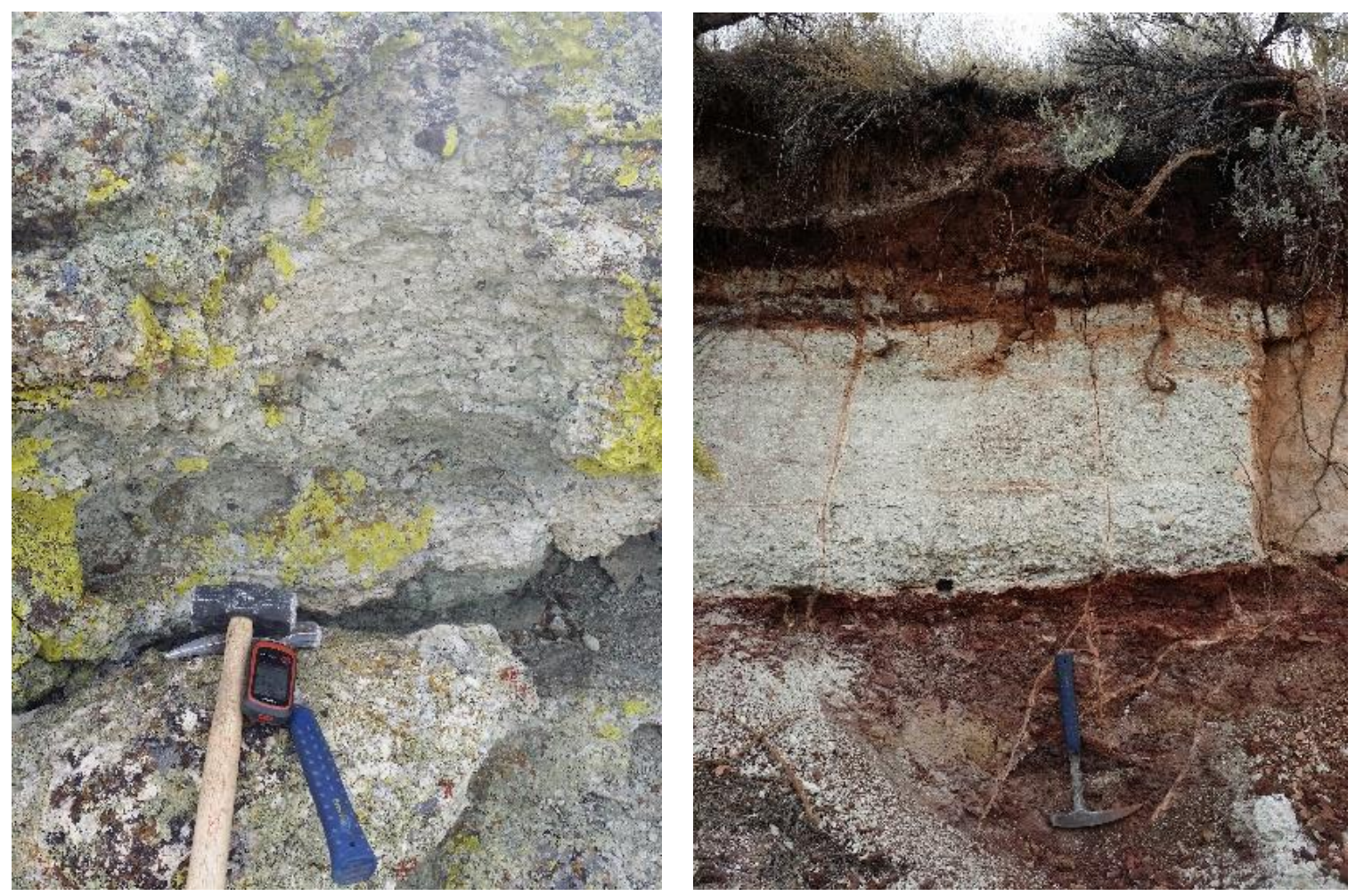

Figure 18: Photograph of unit 2B pyroclastic unit. Welded juvenile and lithic fragments found at northernmost exposures (left) and unwelded juvenile lapilli found in excavation pit on Laton point (right) 
Microscopic characteristics: Phenocryst abundance is $\sim 2 \%$ consisting of plagioclase feldspar. Additional petrographic characteristics are noted in Appendix A-1 for sample B178.

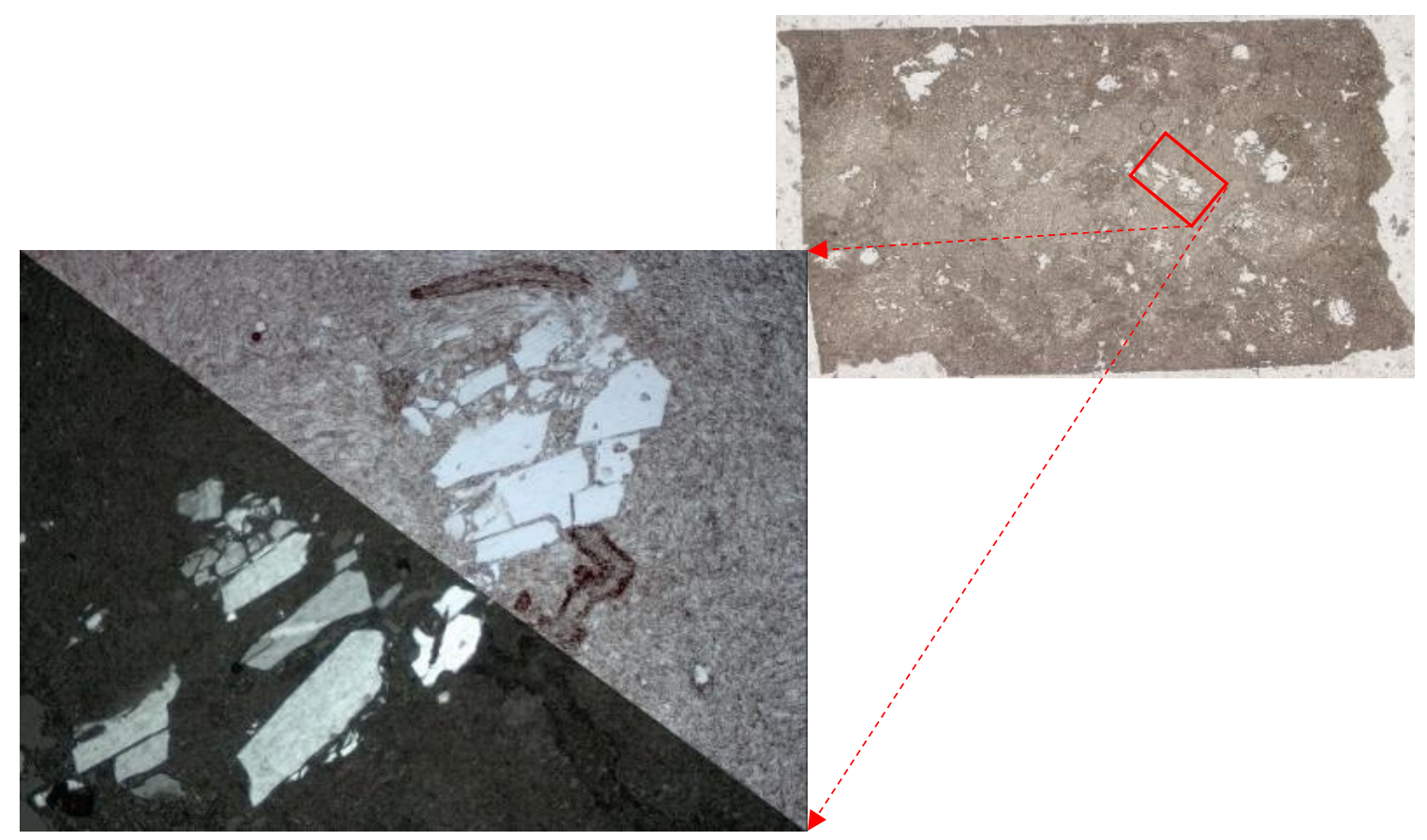

Figure 19: Thin section image of unit 2B (upper right) with highlighted area shown in image under transmitted and cross-polarized light (lower left).

\section{Area 3:}

\section{Unit 3A}

Macroscopic characteristics: Exposed as $3 \mathrm{~m}$ tall cliffs forming low rolling hills (Figure 20). Exposures range from aphryic, very light gray, vesiculated glass to dense black obsidian nodules within vesiculated glass. Numerous exposures of hydrated obsidian with $0.5-5 \mathrm{~cm}$ nodules ("apache tears") weathering out throughout the areal extent of the unit. Hand samples are aphyric with color ranging from very light gray to 
black. Phenocrysts are not present. All samples are vitric however they have various degrees of hydration and vesiculation.

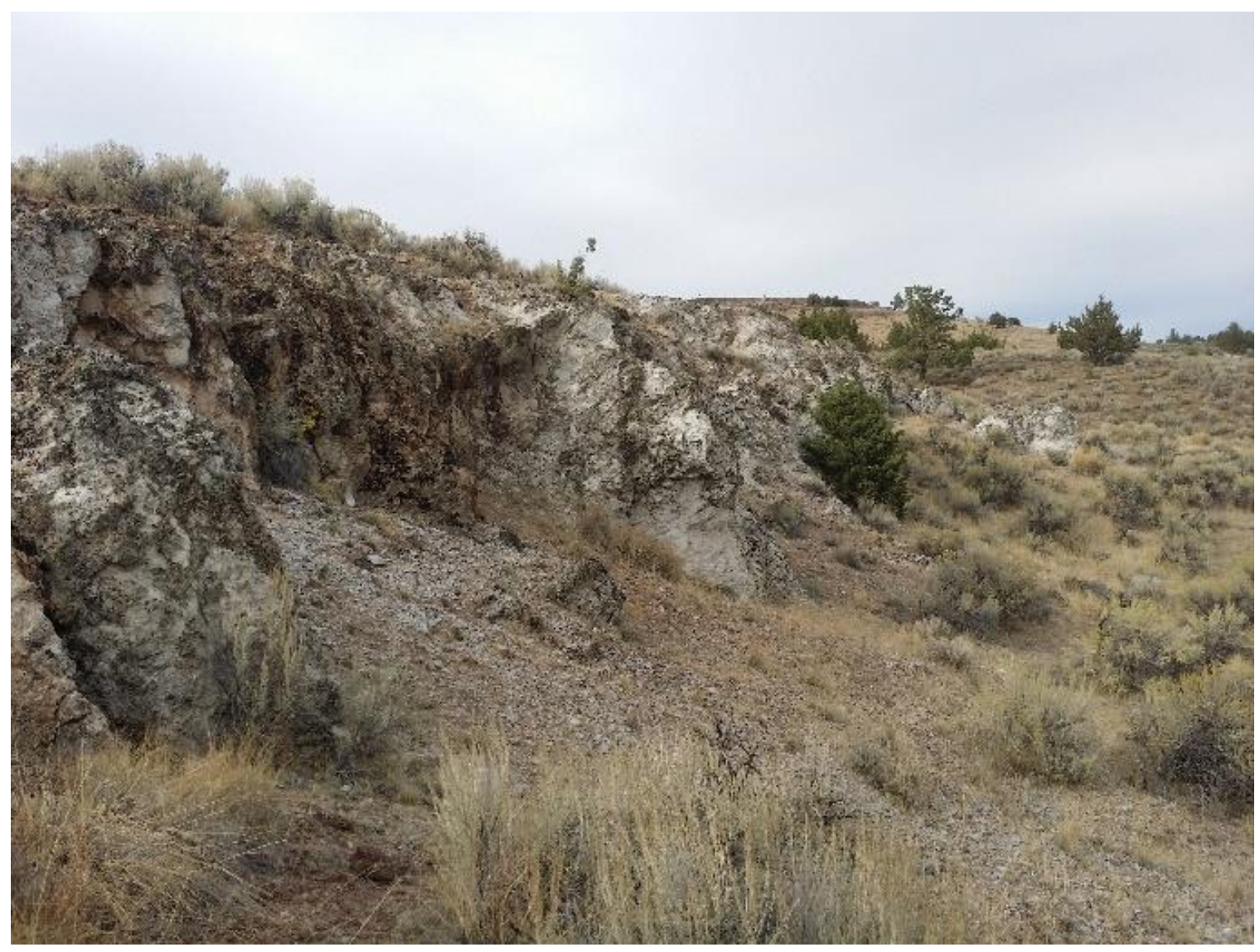

Figure 20: Photograph of unit 3A exposure.

Microscopic characteristics: Samples are aphyric and vitric. Additional petrographic characteristics are noted in Appendix A-1 for sample B185. 


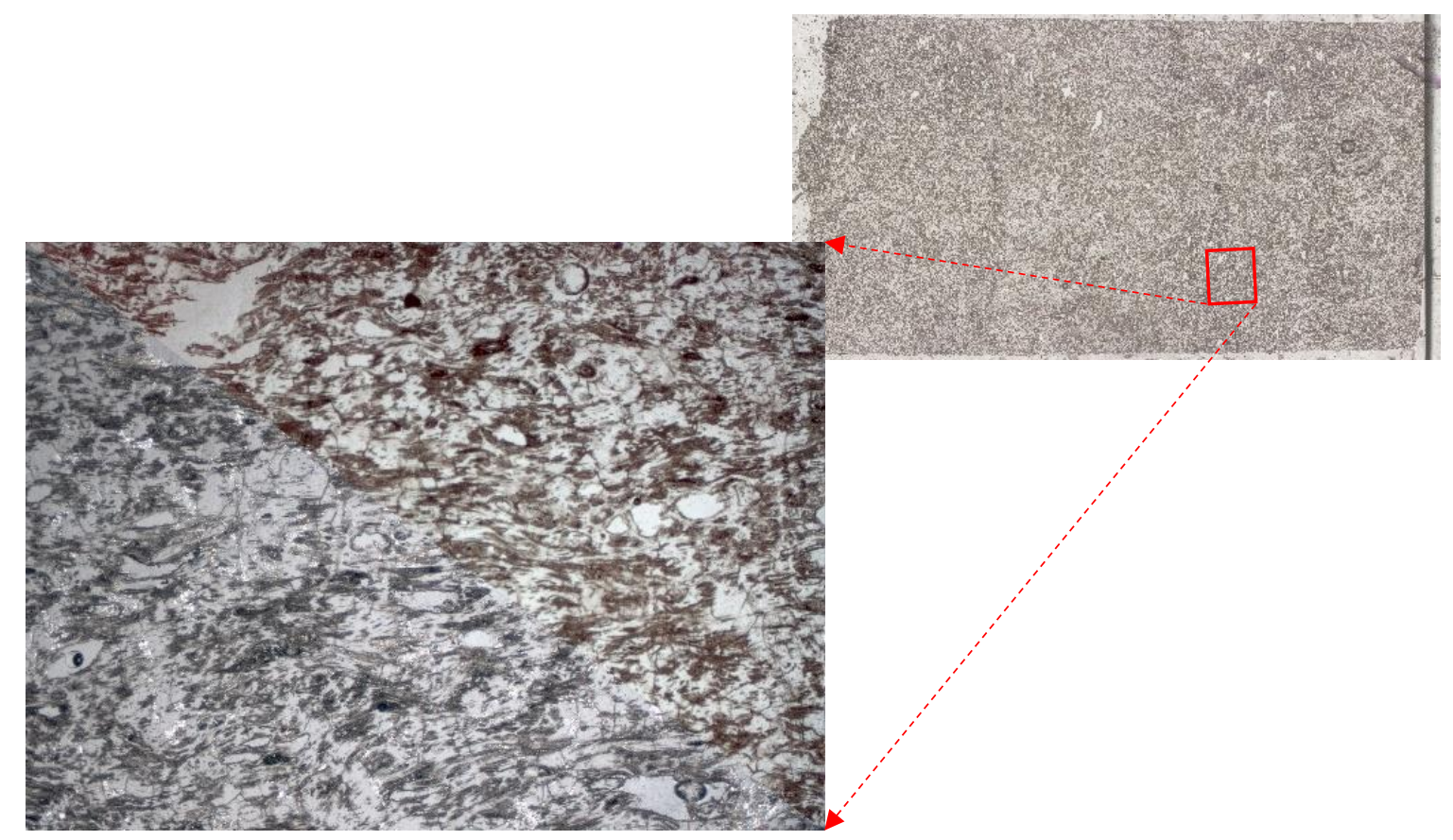

Figure 21: Thin section image of unit 3A (upper right) with highlighted area shown in image under transmitted and cross-polarized light (lower left). Texture of samples due to elongated vesicles.

\section{Mafic unit b3A}

Macroscopic characteristics: Only one occurrence of this mafic unit was identified in area 3. Mafic unit b3B underlies unit 3B; however, the stratigraphic relationship with unit $3 \mathrm{~A}$ is unclear. Exposed as boulders and $\sim 5 \mathrm{~m}$ bedrock outcrop. Hand samples are porphyritic basalt to basaltic andesite with medium gray color. Phenocrysts consist of feldspar and the groundmass is comprised of microlites. Phenocryst abundance is approximately $1 \%$. 


\section{Unit 3B}

Macroscopic characteristics: Exposed along Curtis creek (Figure 22) as 50 m tall cliffs. Hand samples are porphyritic with color ranging from pale red purple to olive gray. Phenocrysts include euhedral equant and tabular feldspar up to $2 \mathrm{~mm}$ and $4 \mathrm{~mm}$ long, respectively. Phenocryst abundance is approximately $15 \%$. Samples collected toward the top of the unit are more altered to a greenish gray color. Some samples have lithic fragments of green aphanitic clasts.
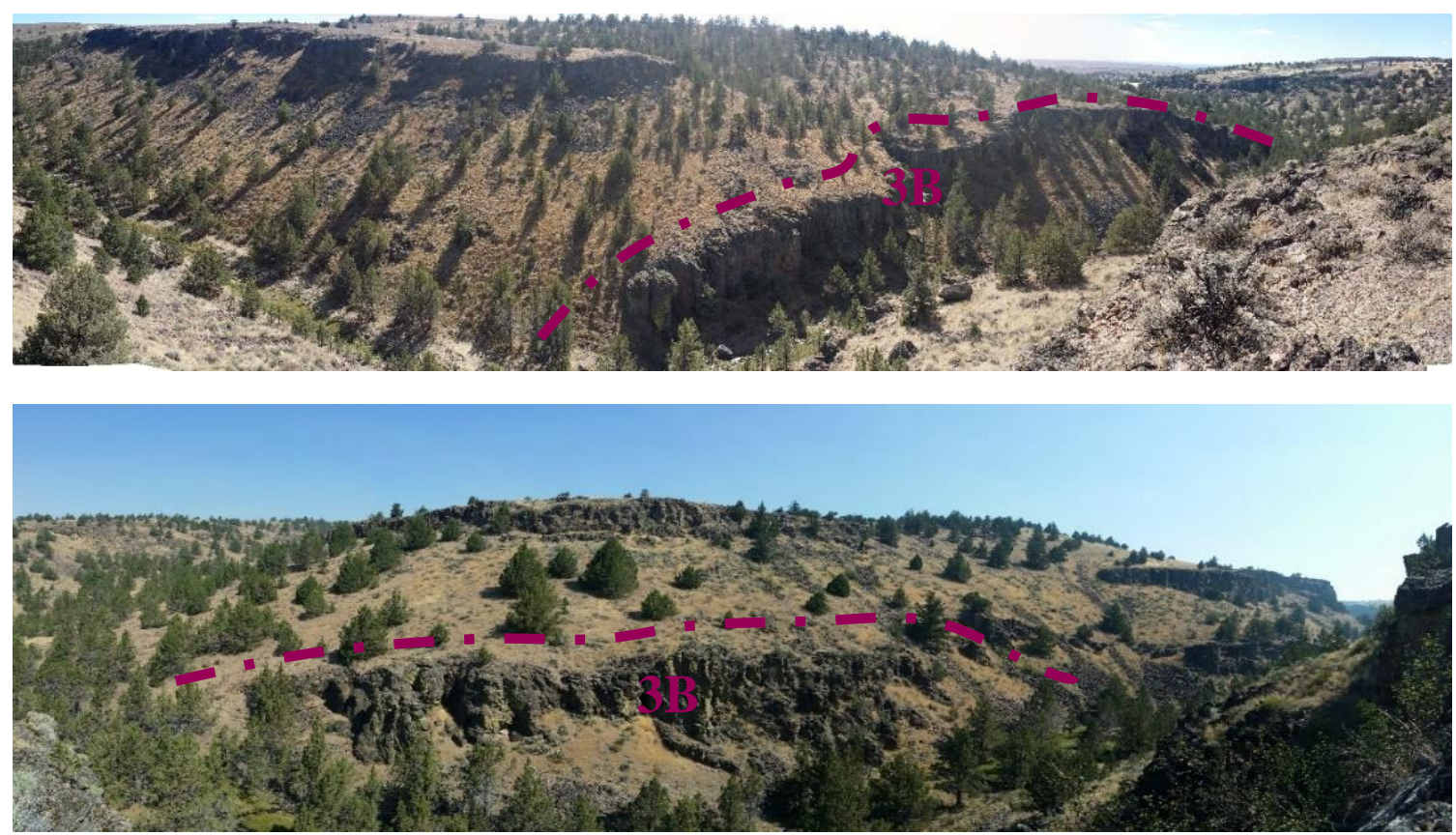

Figure 22: Photograph of unit 3B along Curtis creek. (top)View to the southwest. (bottom) View to the North.

Microscopic characteristics: Phenocryst abundance is $\sim 10 \%$ consisting of $\sim 8 \%$ plagioclase feldspar and $2 \%$ alkali feldspar (Figure 23). Additional petrographic characteristics are noted in Appendix A-1 for samples B155 and B155(p). 


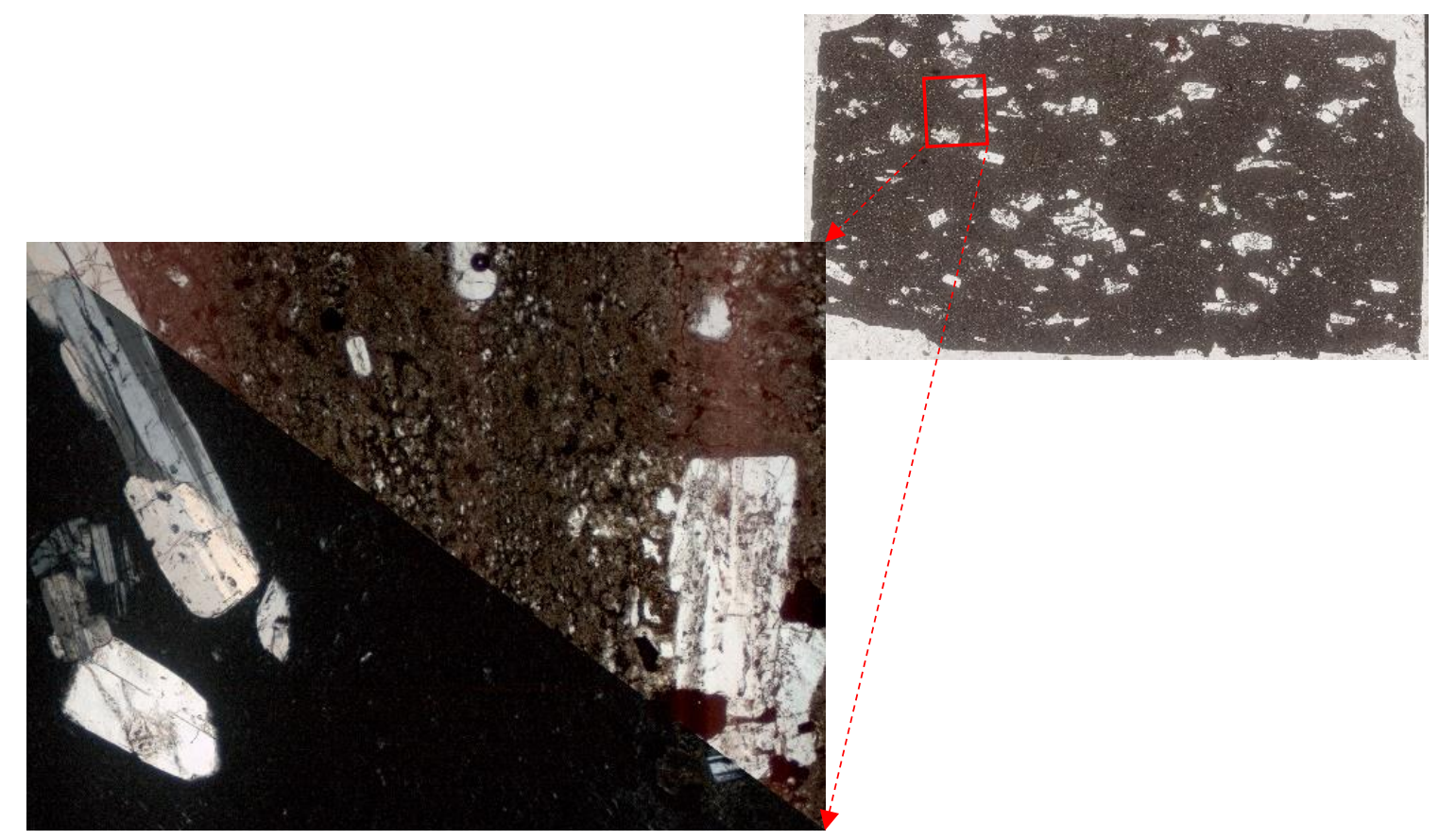

Figure 23: Thin section image of unit 3B (upper right) with highlighted area shown in image under transmitted and cross-polarized light (lower left).

SEM analysis confirms that there are two populations of feldspar, sanidine and

$\mathrm{An}_{22}$ plagioclase (Table 5 and Figure 24).

Table 5: Feldspar composition for unit 3B calculated from data obtained by SEM.

\begin{tabular}{cccc|cccc}
\hline $\begin{array}{c}\text { Feldspar population } \\
155-1 \mathrm{n}=6\end{array}$ & Or & $\mathrm{Ab}$ & $\mathrm{An}$ & Feldspar population & & & \\
\hline Mean & 9 & 69 & 22 & Mean & 58 & 42 & 0 \\
Minimum & 7 & 66 & 20 & Minimum & 56 & 41 & 0 \\
Maximum & 10 & 70 & 27 & Maximum & 59 & 43 & 2 \\
Standard Deviation & 1.12 & 1.16 & 2.29 & Standard Deviation & 0.72 & 0.41 & 0.77 \\
\hline
\end{tabular}




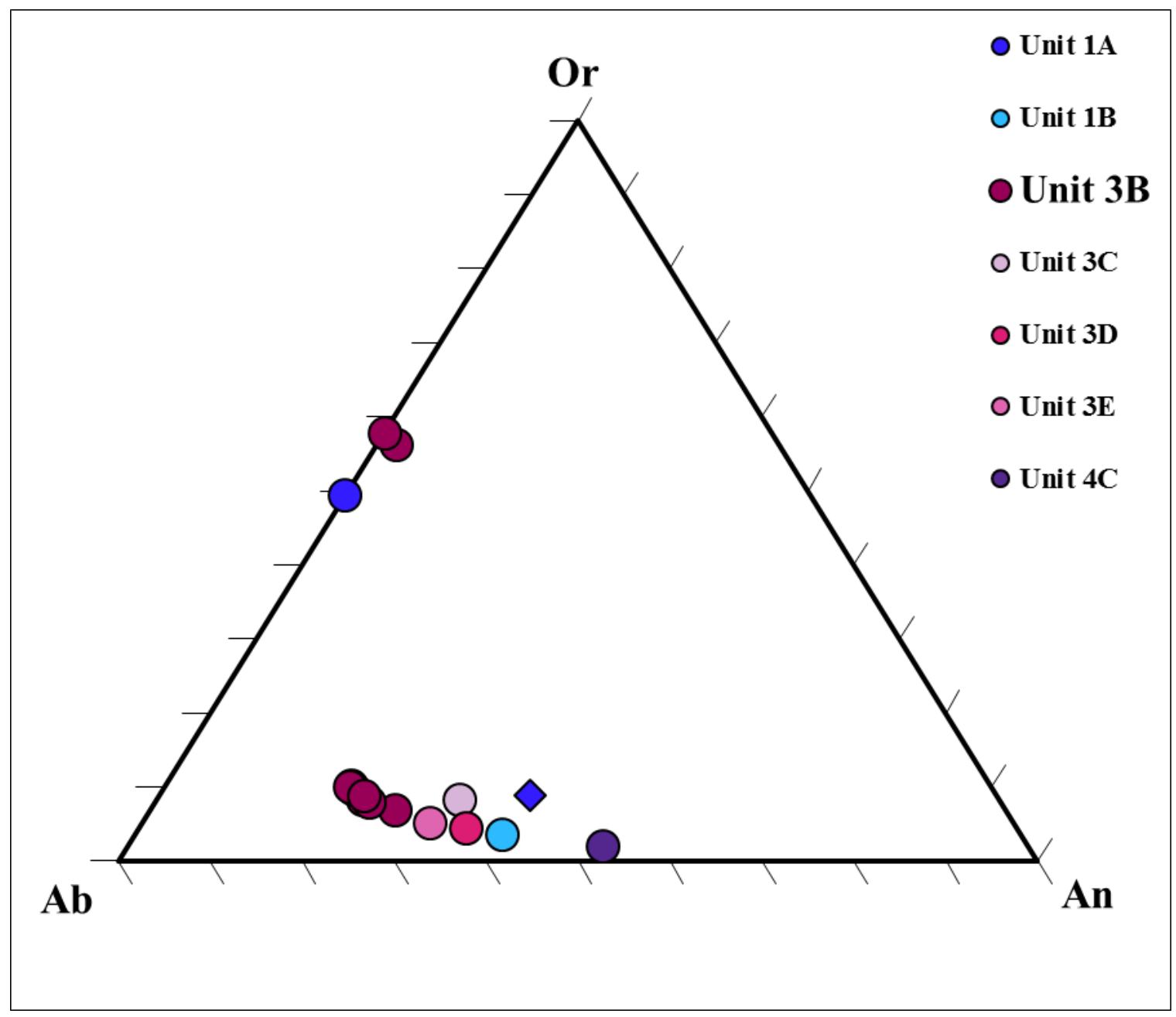

Figure 24: Feldspar ternary plot based on SEM data showing all analysis results for Unit 3B (dark pink) and averages for all other rhyolite units analyzed.

\section{Unit 3C}

Macroscopic characteristics: Exposed overlying unit 3B along Curtis creek (Figure 25) as $50 \mathrm{~m}$ cliffs and as bedrock outcrop and cliffs south and west of Curtis Creek (Figure 26). Hand samples are aphanitic with variable colors including dark gray, medium gray, greenish gray and grayish red. Phenocryst abundance (if phenocrysts are present) is $<1 \%$ and consist of euhedral feldspar $<1 \mathrm{~mm}$. 

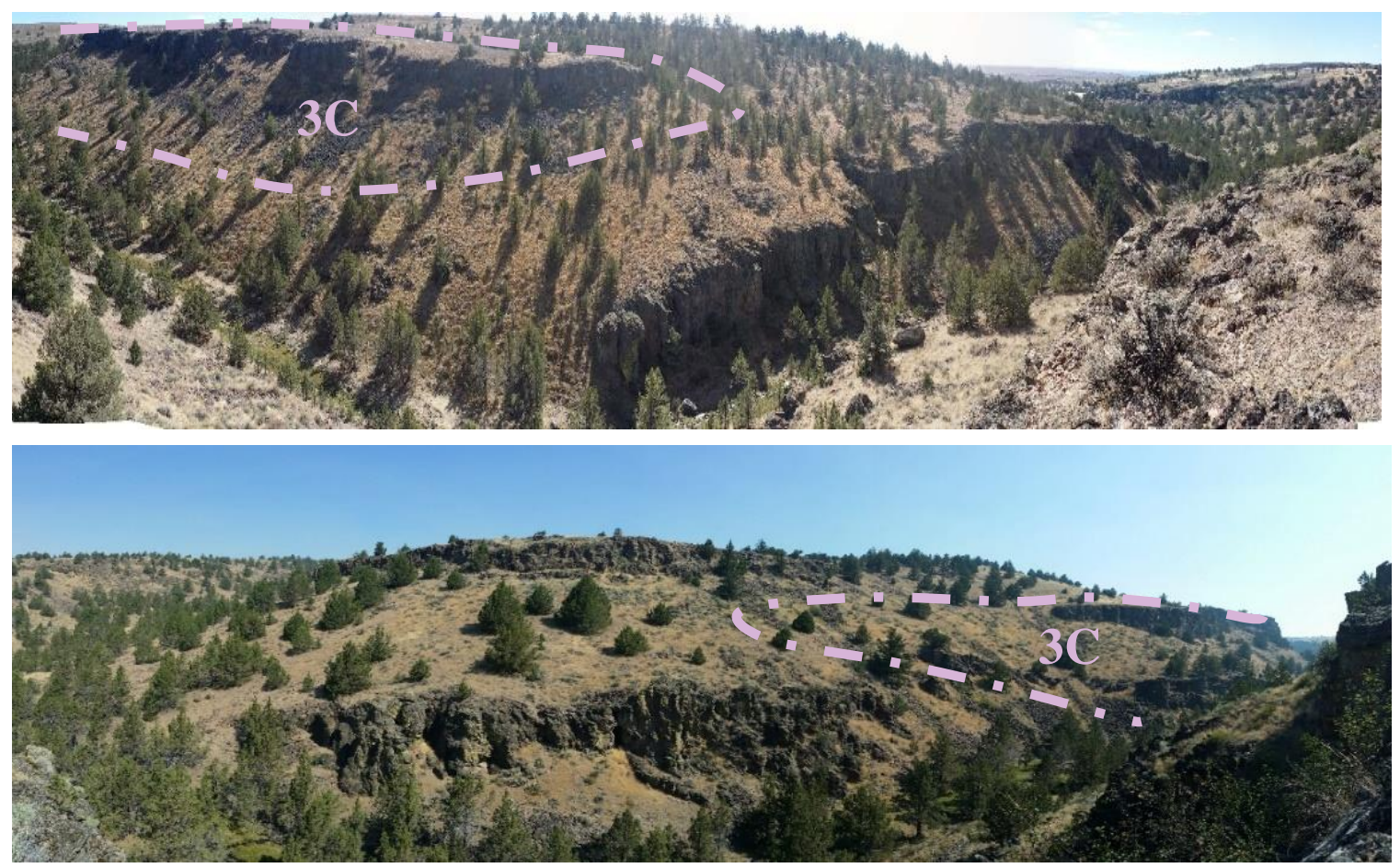

Figure 25: Photograph of unit 3C along Curtis creek. (top)View to the southwest. (bottom) View to the North.
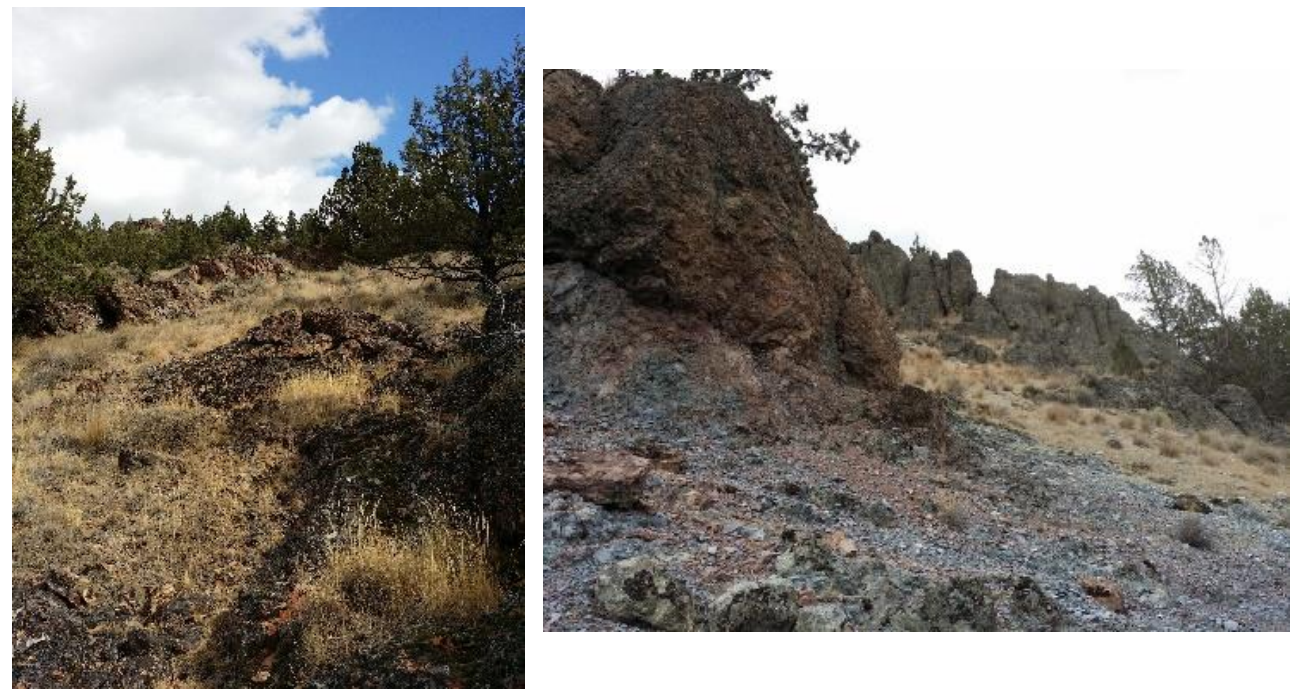

Figure 26: Photographs of unit 3C boulder (left) and cliff (right) outcrops. Image on right shows basal breccia of unit 3C overlying glassy unit 3A.

Microscopic characteristics: Phenocryst abundance is $\sim 1 \%$ consisting of euhedral to subhedral feldspar (Figure 27). Additional petrographic characteristics are noted in Appendix A-1 for samples B159(p) and B163. 


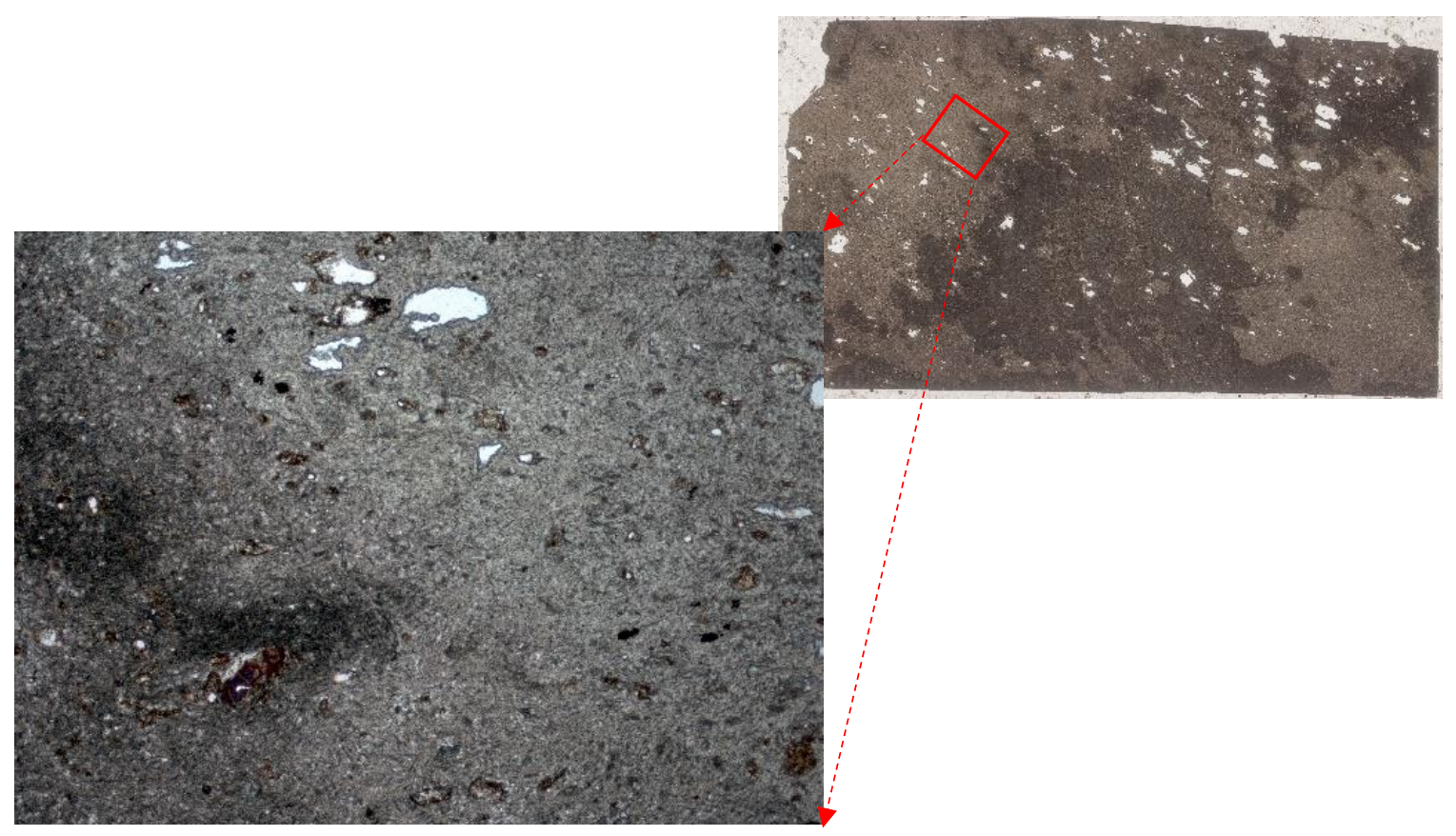

Figure 27: Thin section image of unit 3C (upper right) with highlighted area shown in image under transmitted and cross-polarized light (lower left).

SEM results indicate that the analyzed feldspar are $\mathrm{An}_{33}$ plagioclase (Table 6 and

Figure 28).

Table 6: Feldspar composition for unit 3C calculated from data obtained by SEM.

\begin{tabular}{cccc}
\hline $\begin{array}{c}\text { B159 feldspar } \\
\text { population, } \mathrm{n}=5\end{array}$ & Or & $\mathrm{Ab}$ & $\mathrm{An}$ \\
\hline \hline Mean & 8 & 59 & 33 \\
Minimum & 3 & 49 & 25 \\
Maximum & 13 & 62 & 48 \\
Standard & & & \\
Deviation & 3.47 & 5.01 & 8.20 \\
\hline
\end{tabular}




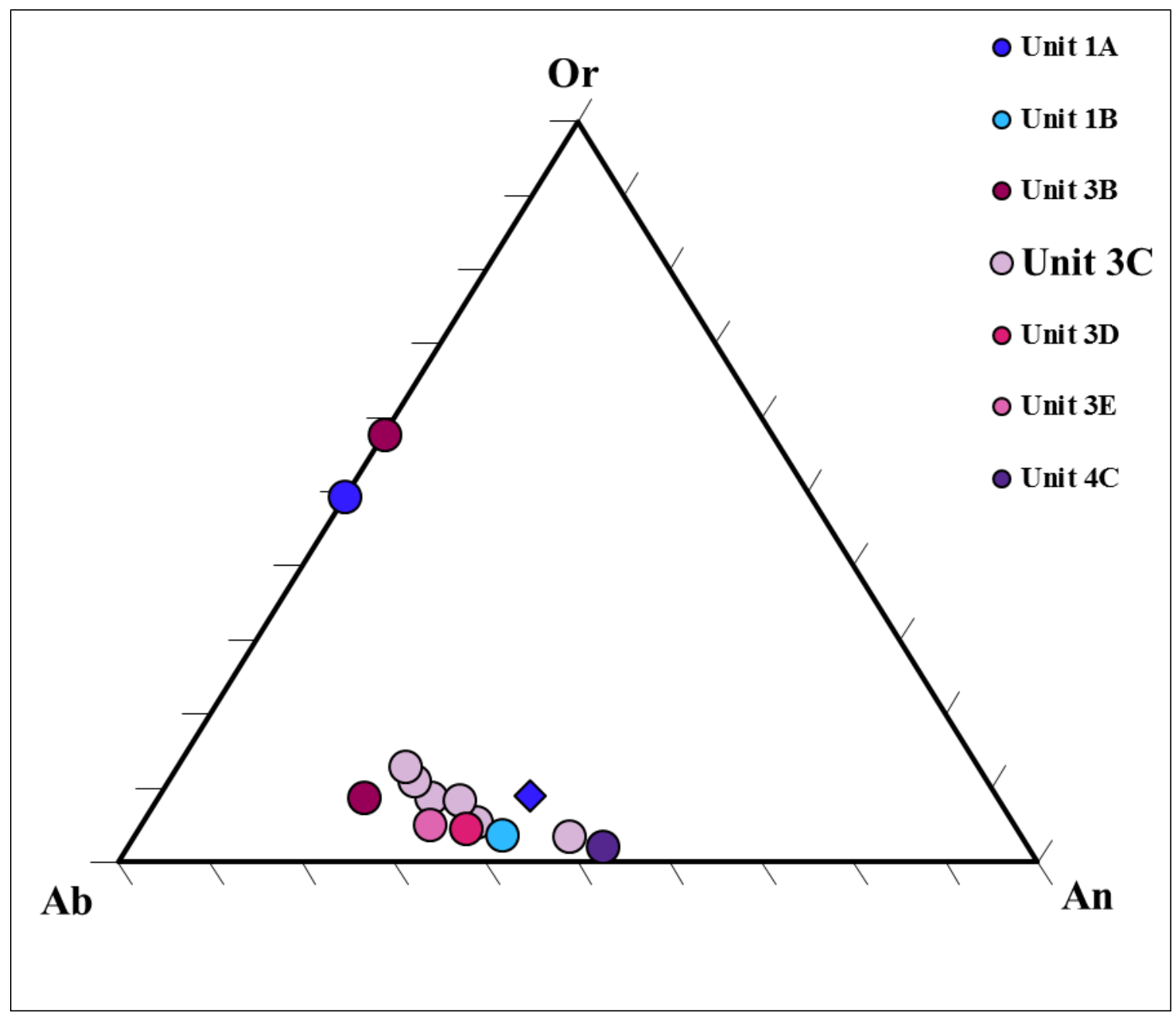

Figure 28: Feldspar ternary plot based on SEM data showing all analysis results for Unit 3C (pale pink) and averages for all other rhyolite units analyzed. 


\section{Unit 3D}

Macroscopic characteristics: Exposed as $\sim 20 \mathrm{~m}$ tall cap rock cliffs on ridge north of Curtis creek (Figure 29) and is the dominate bedrock unit forming the valley and ridge to the east. Hand samples are porphyritic with variable colors including yellowish gray, pale pink and brownish gray. Phenocrysts include euhedral feldspar up to $3 \mathrm{~mm}$. Phenocryst abundance is variable and ranges from $\sim 2 \%$ to $\sim 10 \%$. The majority of samples are flow banded.

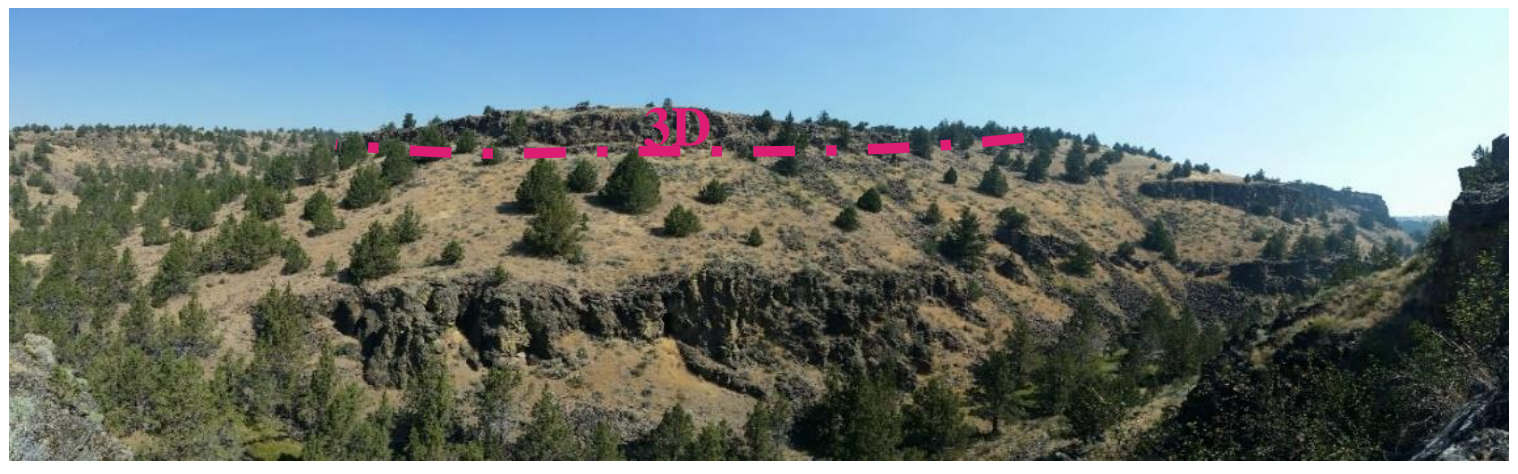

Figure 29: Photograph of unit 3D along Curtis creek. View to the north.

Microscopic characteristics: Phenocryst abundance in thin sections examined is $\sim 5-8 \%$, consisting of euhedral plagioclase feldspar (Figure 30). Additional petrographic characteristics are noted in Appendix A-1 for samples B165 and B165(p). 


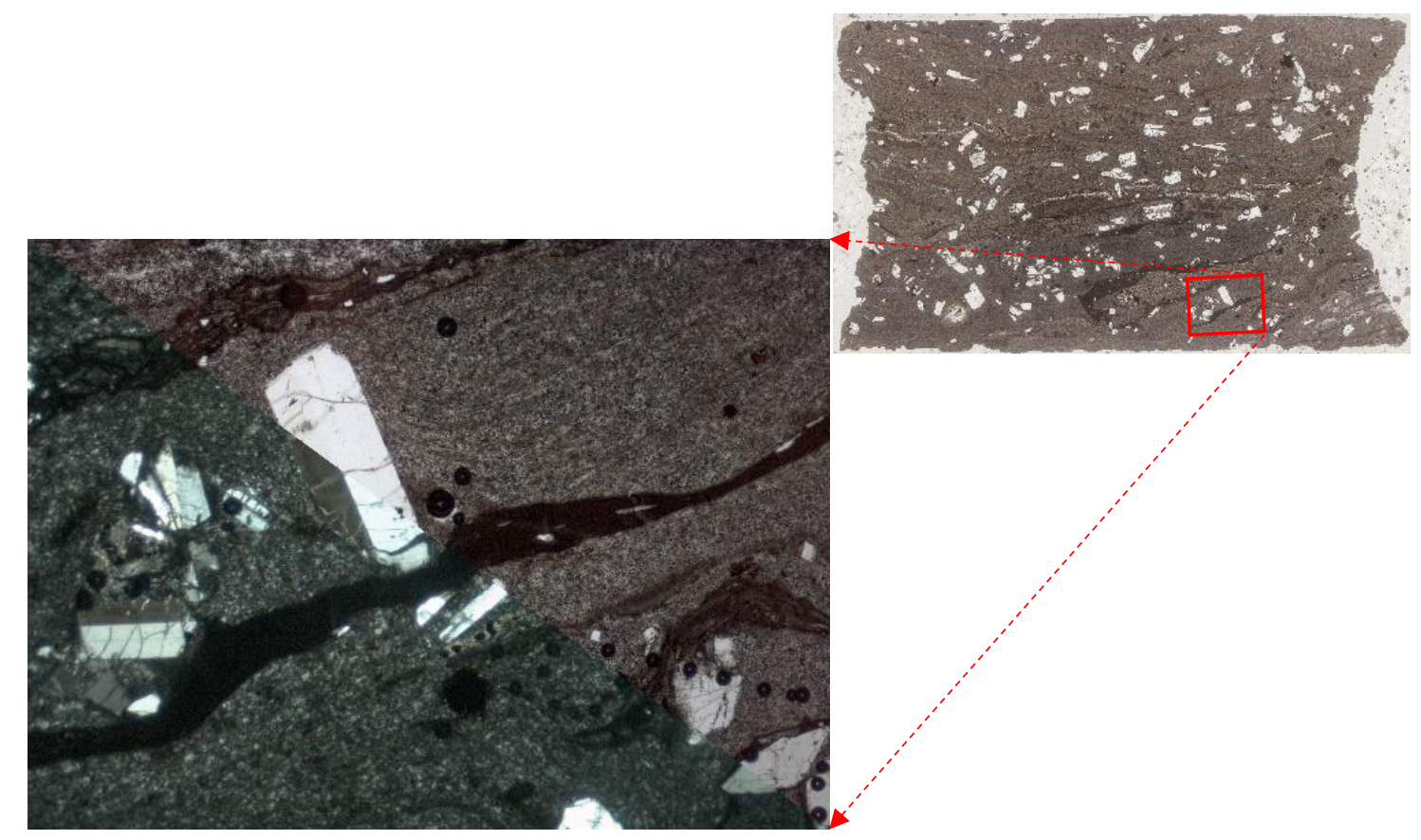

Figure 30: Thin section image of unit 3D (upper right) with highlighted area shown in image under transmitted and cross-polarized light (lower left).

SEM analysis indicates that the analyzed feldspar are $\mathrm{An}_{36}$ plagioclase (Table 7 and Figure 31).

Table 7: Feldspar composition for unit 3D calculated from data obtained by SEM.

\begin{tabular}{lccc}
\hline B165 feldspar & & & \\
population, $\mathrm{n}=14$ & Or & $\mathrm{Ab}$ & $\mathrm{An}$ \\
\hline \hline Mean & 4 & 60 & 36 \\
Minimum & 4 & 58 & 32 \\
Maximum & 5 & 63 & 38 \\
Standard Deviation & 0.34 & 1.20 & 1.46 \\
\hline
\end{tabular}




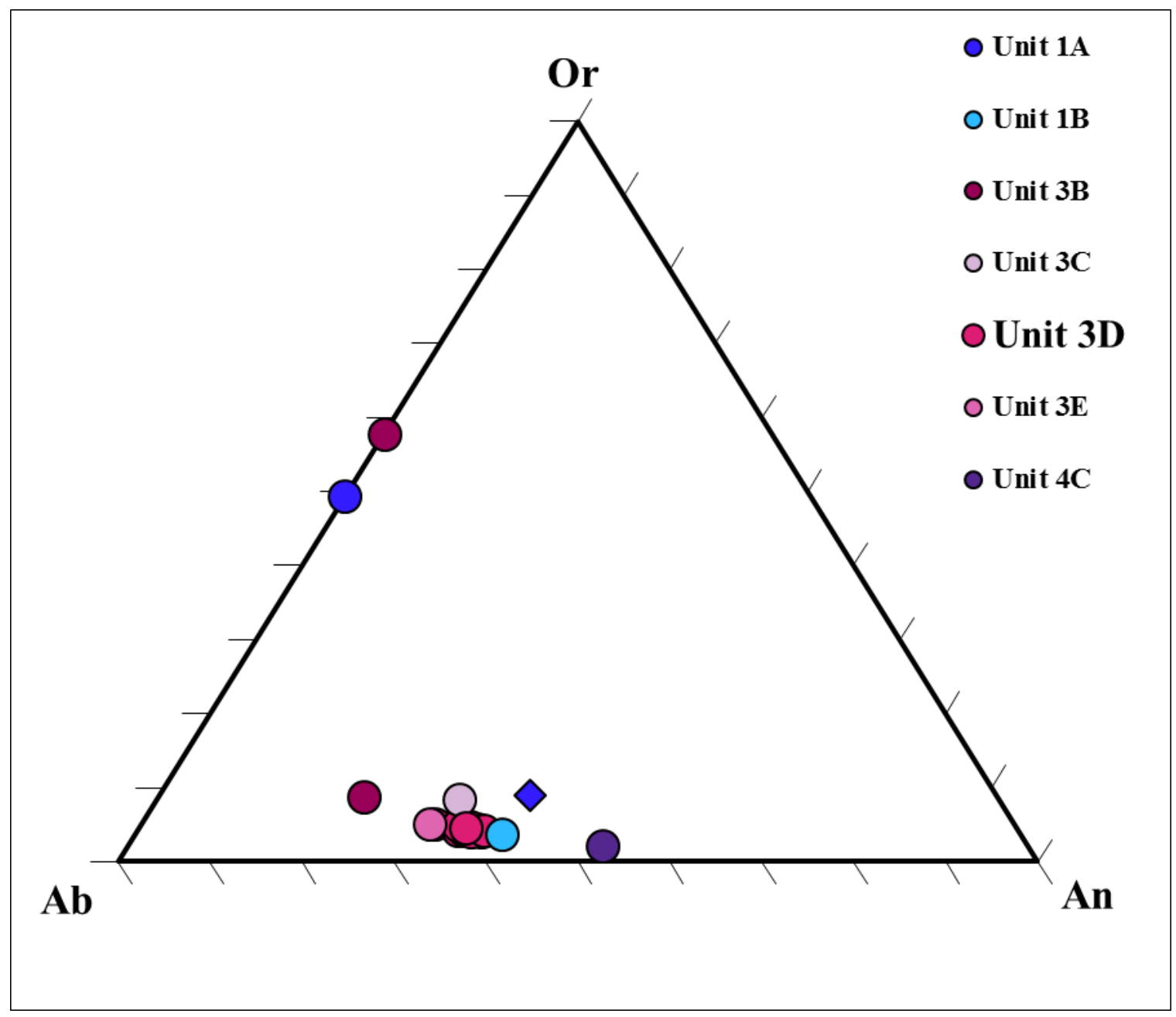

Figure 31: Feldspar ternary plot based on SEM data showing all analysis results for Unit 3D (medium pink) and averages for all other rhyolite units analyzed.

\section{Unit 3E}

Macroscopic characteristics: Exposed as bedrock outcrops on the top of the northeastern ridge in area 3. Hand samples are aphyric to phyric with variable colors including grayish pink, yellowish gray, light gray to dark gray and dark reddish brown. Phenocryst abundance is $\sim 0-5 \% \%$. 
Microscopic characteristics: Phenocryst abundance is $\sim 0-5 \%$, consisting of subhedral to euhedral plagioclase feldspar (Figure 30). Additional petrographic characteristics are noted in Appendix A-1 for samples B165 and B165(p).

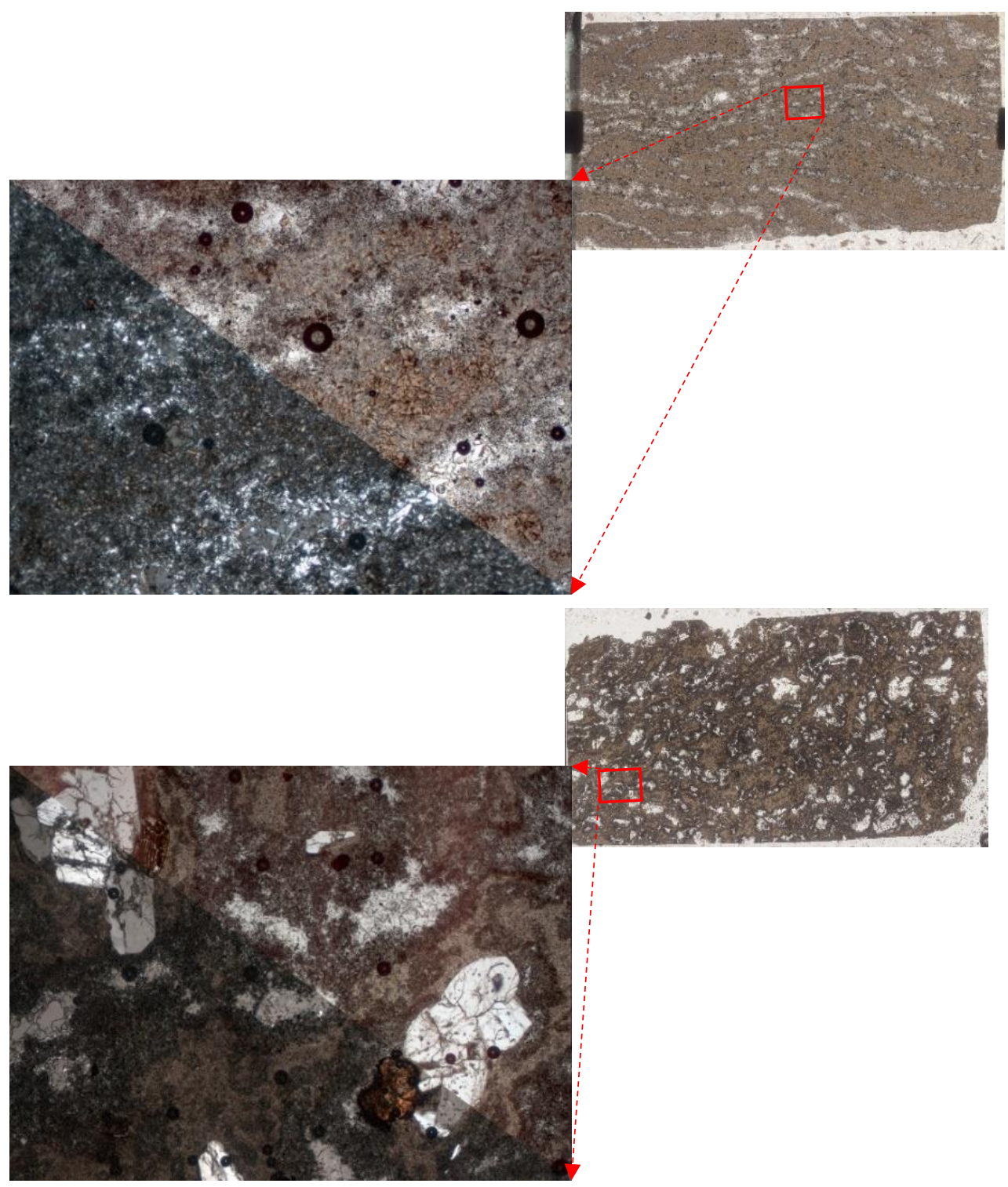

Figure 32: Two thin section image of unit 3E. (top) Aphyric sample (bottom) Phyric sample SEM analysis indicates that the analyzed feldspar are $\mathrm{An}_{31}$ plagioclase (Table 8 and Figure 33). 
Table 8: Feldspar composition for unit 3E calculated from data obtained by SEM.

\begin{tabular}{lccc}
\hline $\begin{array}{l}\text { B172 feldspar } \\
\text { population, } \mathrm{n}=13\end{array}$ & Or & $\mathrm{Ab}$ & $\mathrm{An}$ \\
\hline \hline Mean & 5 & 64 & 31 \\
Minimum & 3 & 54 & 27 \\
Maximum & 6 & 67 & 43 \\
Standard & & & \\
Deviation & 0.87 & 3.55 & 4.37 \\
\hline
\end{tabular}

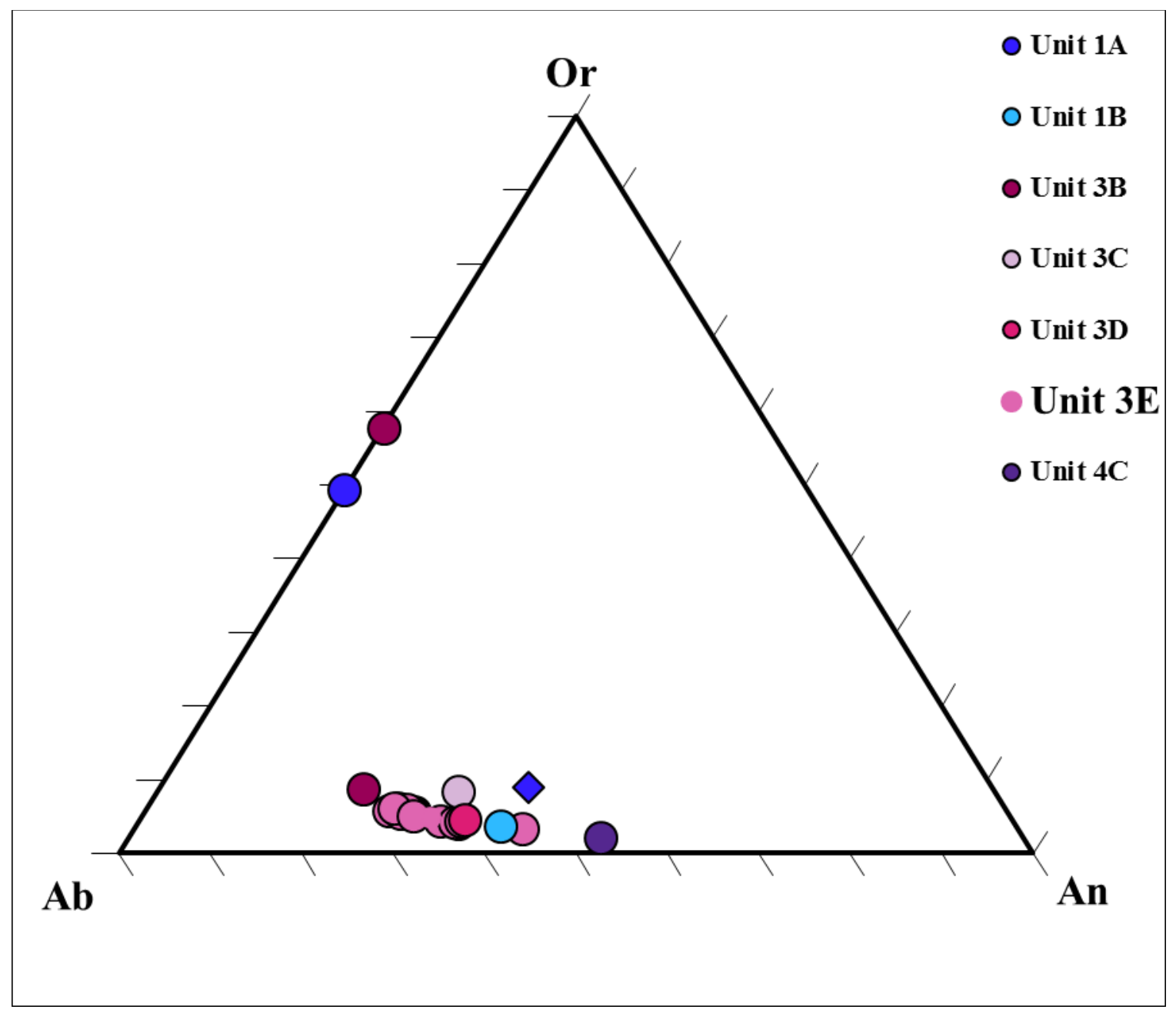

Figure 33: Feldspar ternary plot based on SEM data showing all analysis results for Unit 3E (light pink) and averages for all other rhyolite units analyzed. 


\section{Unit 3F}

Macroscopic characteristics: Exposed as ridge forming bedrock outcrop in the north of the study area and smaller isolated areas. Unit 3F is an ash-flow tuff. One small outcrop was found to be incipiently welded however most occurrences are strongly welded. This unit was previously identified as the Buchanan ash-flow tuff by Brown and McLean (1980).

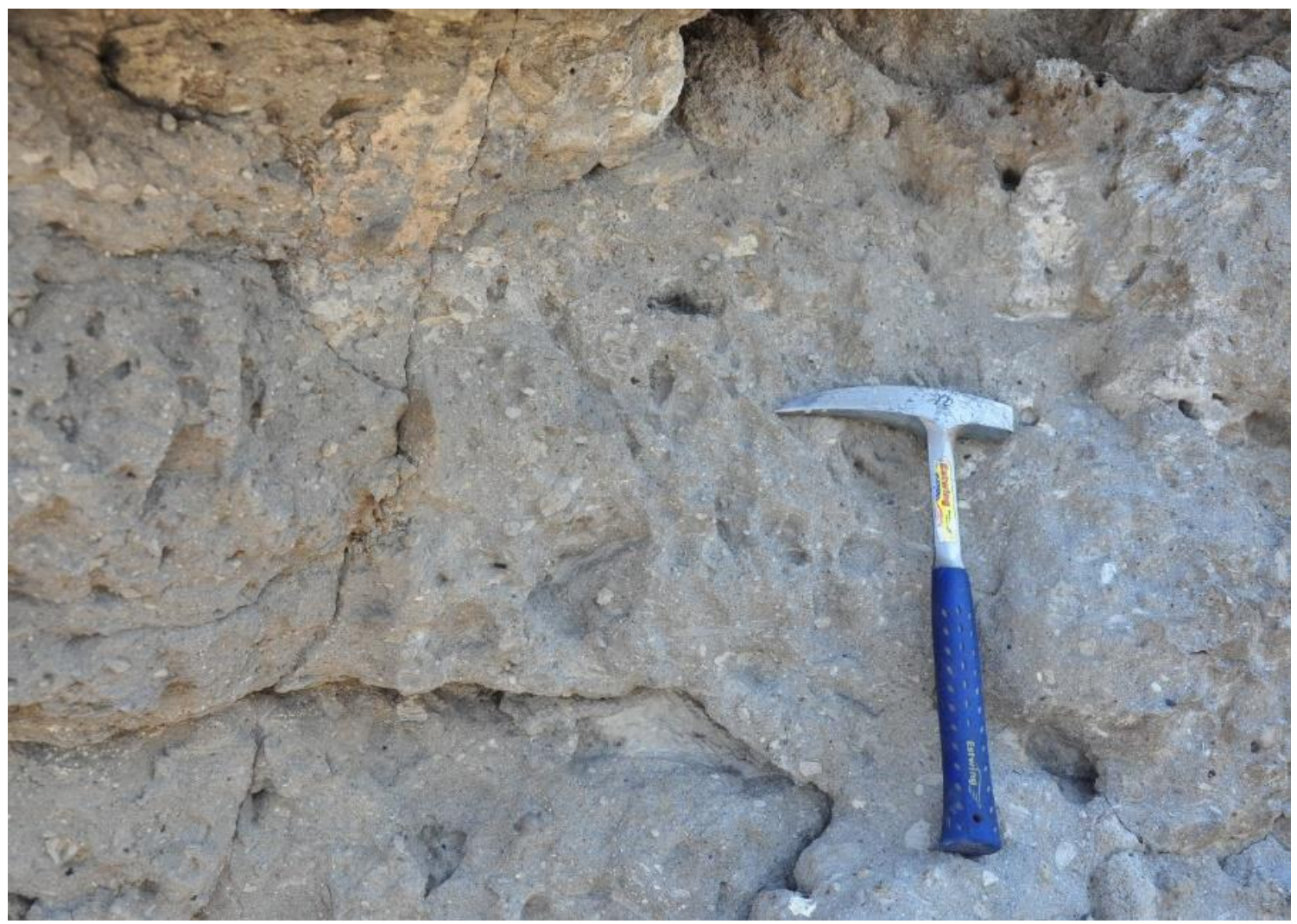

Figure 34: Photograph of unit 3F incipiently welded exposure.

Hand samples are tuffaceous with color ranging from medium light gray to light olive gray. Samples consist of ash, $~ 30 \%$ pumice and $~ 10 \%$ lithic fragments, with deformation of the pumice variable based on the degree of welding. Phenocrysts include euhedral feldspar up to $2 \mathrm{~mm}$. 
Microscopic characteristics: Phenocryst abundance is $\sim 5 \%$, consisting of euhedral plagioclase feldspar (Figure 35). Additional petrographic characteristics are noted in Appendix A-1 for samples B191.

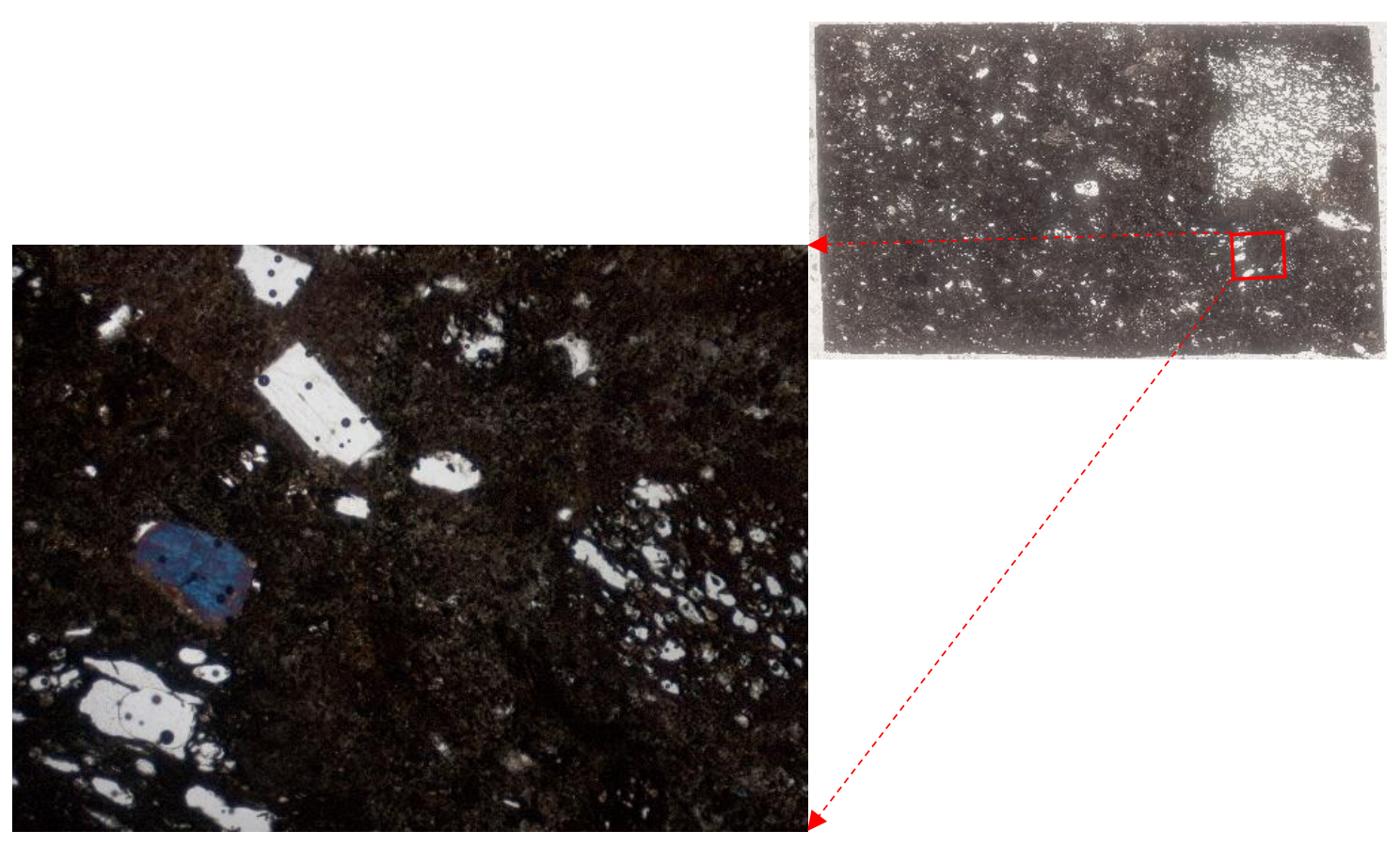

Figure 35: Thin section image of unit 3F (upper right) with highlighted area shown in image under transmitted and cross-polarized light (lower left).

\section{Area 4:}

\section{Unit 4A}

Macroscopic characteristics: Exposed in bedrock outcrops and $\sim 10 \mathrm{~m}$ tall cliffs near Mahon creek. Hand samples are porphyritic with color ranging from medium gray to pale pink. Phenocrysts are sparse and consist of euhedral feldspar. Phenocryst abundance is approximately $1 \%$. 


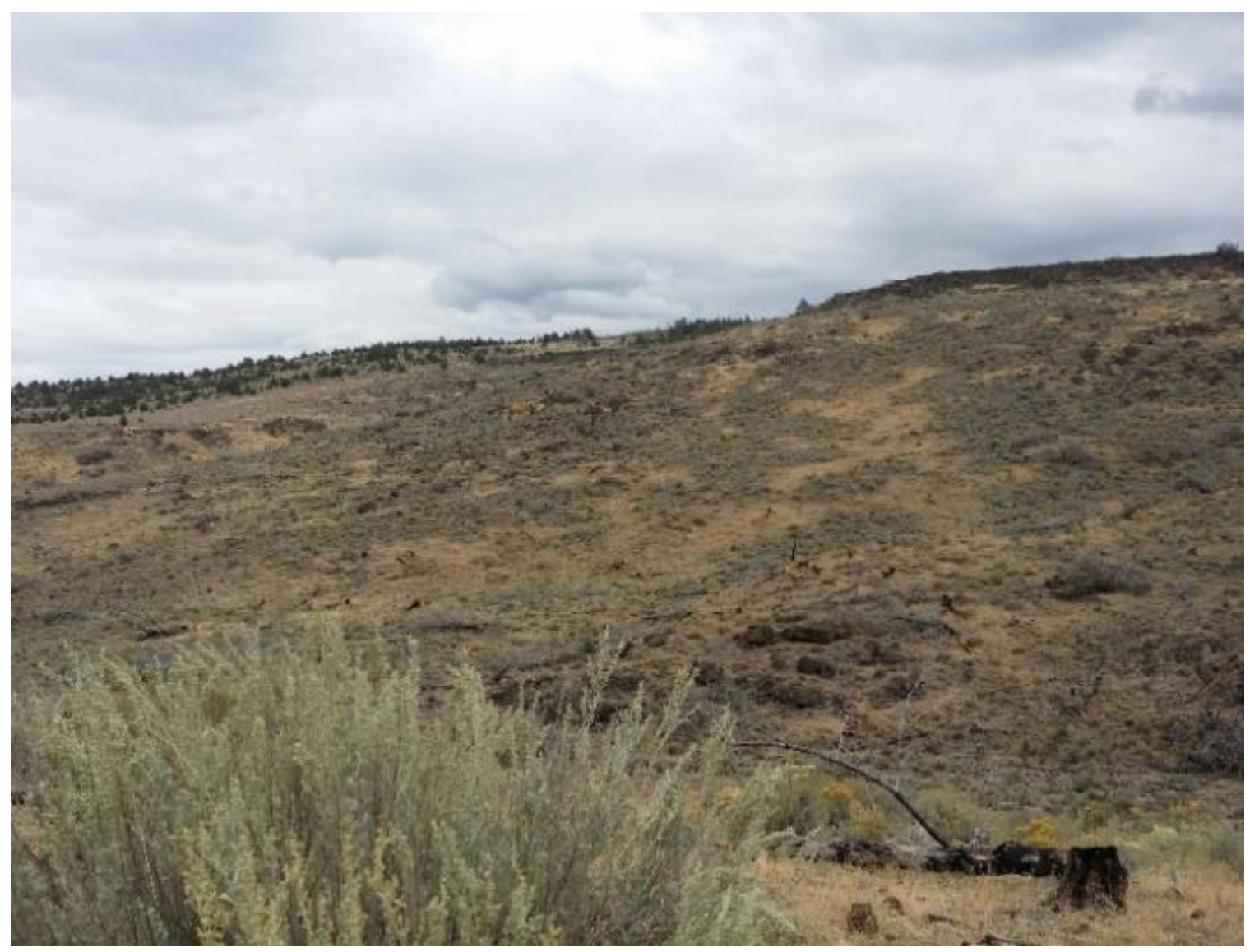

Figure 36: Photograph of unit 4A. Devine Canyon tuff caps the ridge and unit 4A is exposed on slopes.

Microscopic characteristics: Phenocryst abundance is approximately $1 \%$ consisting of plagioclase feldspar. Additional petrographic characteristics are noted in Appendix A-1 for sample B175. 


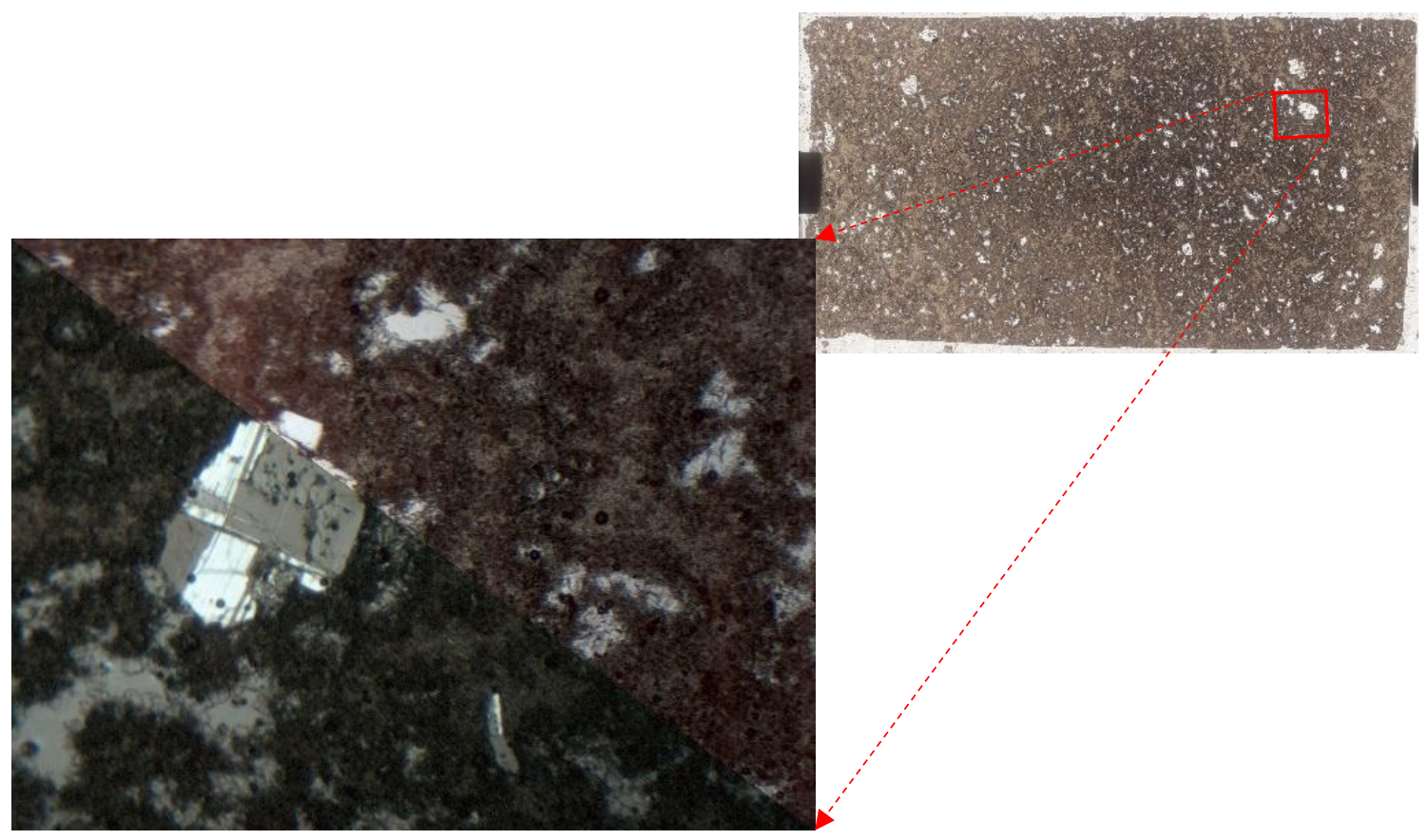

Figure 37: Thin section image of unit 4A (upper right) with highlighted area shown in image under transmitted and cross-polarized light (lower left).

\section{Mafic unit b4A}

Macroscopic characteristics: Exposed as boulder outcrops. Hand samples are porphyritic basalt to basaltic andesite with colors ranging from medium gray to light brownish gray. Phenocrysts consist of feldspar and the groundmass is comprised of microlites. Phenocryst abundance is approximately $1 \%$.

Microscopic characteristics: Phenocryst abundance is approximately $1 \%$ consisting of plagioclase feldspar. Additional petrographic characteristics are noted in Appendix A-1 for sample B175. 


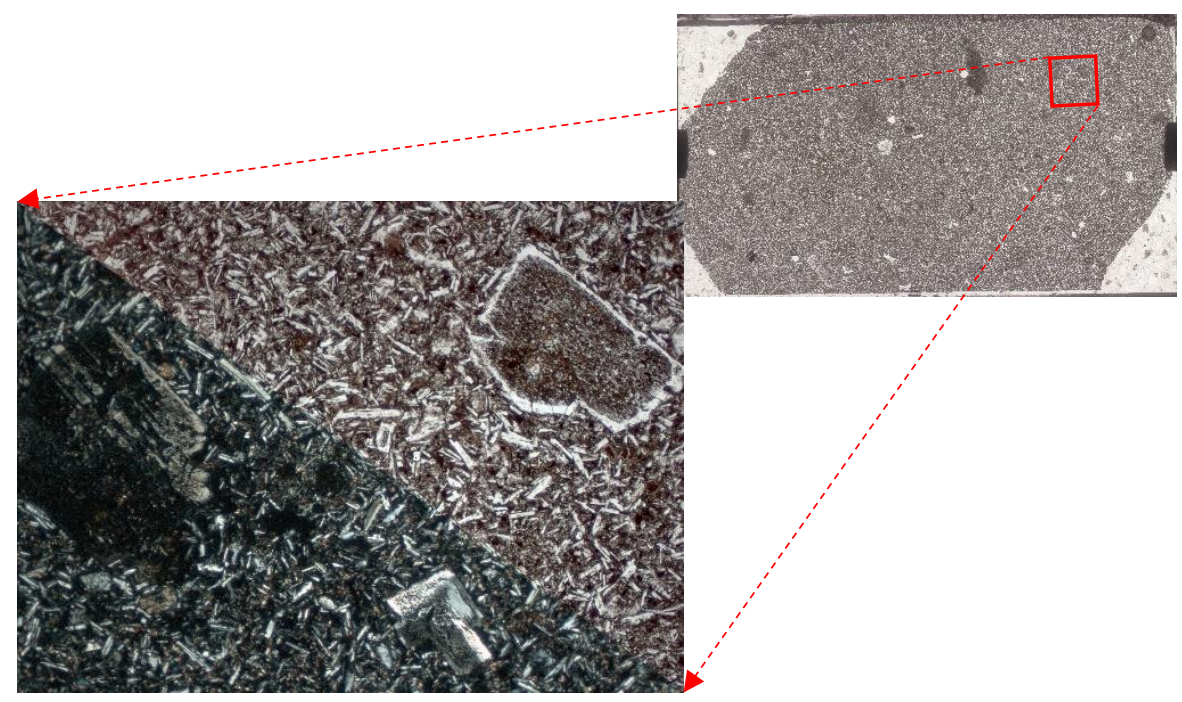

Figure 38: Thin section image of unit b4A (upper right) with highlighted area shown in image under transmitted and cross-polarized light (lower left).

\section{Unit 4B}

Macroscopic characteristics: Exposed as obsidian nodules and vitric bedrock between basaltic andesite units $\mathrm{b} 4 \mathrm{~A}$ and $\mathrm{b} 4 \mathrm{~B}$. Thickness of unit is $\sim 10 \mathrm{~m}$. Hand samples are aphyric with color ranging from black to medium gray.

\section{Mafic unit b4B}

Macroscopic characteristics: Exposed as bedrock outcrop and boulders overlying unit 4B. Hand samples are porphyritic basalt to basaltic andesite with colors ranging from medium gray to grayish black. Phenocryst abundance is $\sim 15 \%$ and consists of blocky and tabular feldspar up to $1 \mathrm{~mm}$ and $3 \mathrm{~mm}$ long, respectively. Irregular shaped vesicles up to $2 \mathrm{~mm}$ are common. 


\section{Unit 4C}

Macroscopic characteristics: Exposed as bedrock outcrops and boulders forming a ridge and several hills. Hand samples are porphyritic with color predominantly medium gray. Phenocrysts include euhedral feldspar up to $3 \mathrm{~mm}$ and altered pyroxene $\sim 1 \mathrm{~mm}$.

Phenocryst abundance is approximately $10-15 \%$.

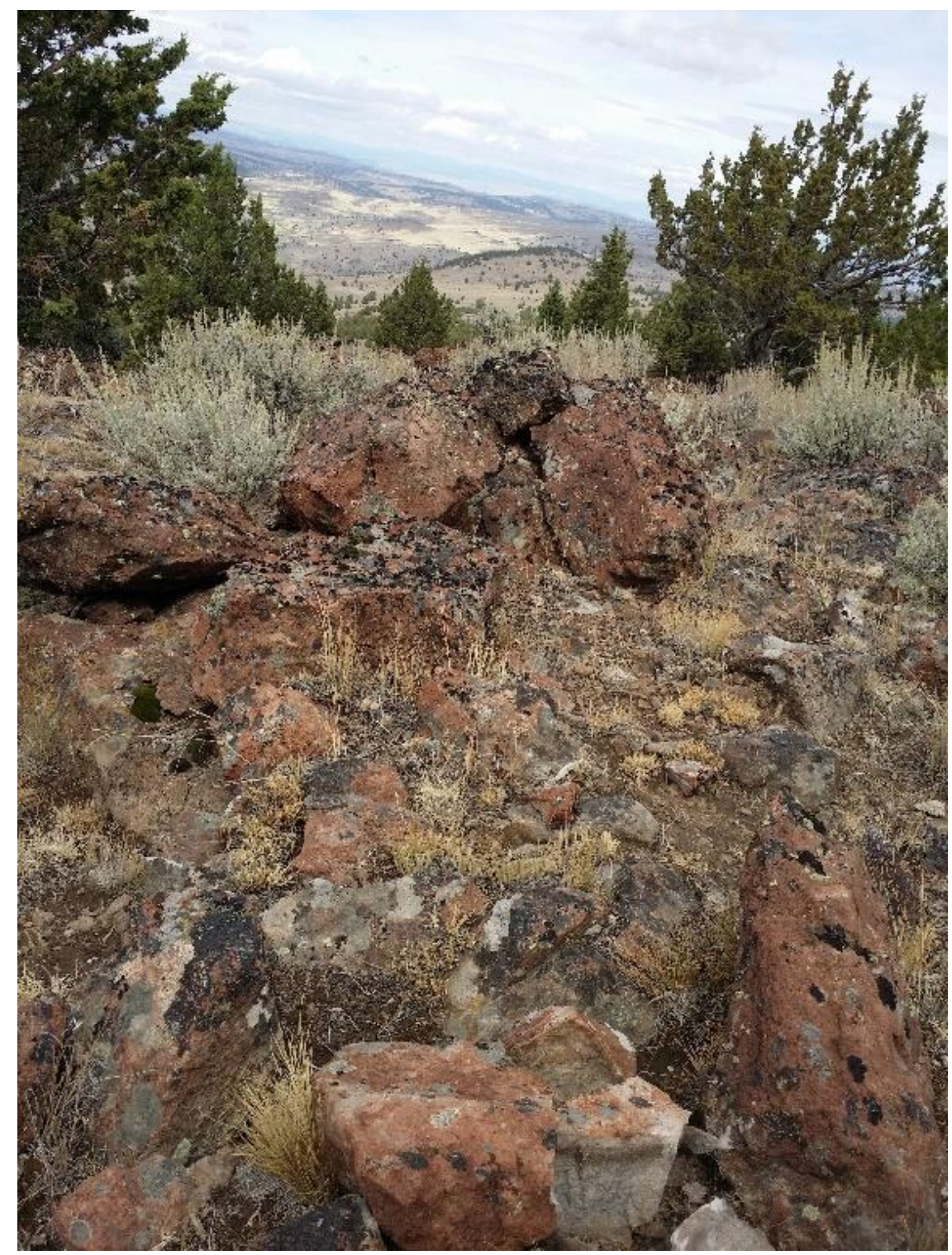

Figure 39: Photograph of unit 4C on top of ridge. 
Microscopic characteristics: Phenocryst abundance is approximately $10 \%$ consisting of plagioclase feldspar and minor amounts of clinopyroxene and biotite (Figure 40). Additional petrographic characteristics are noted in Appendix A-1 for samples B112, B114 and B114(p).

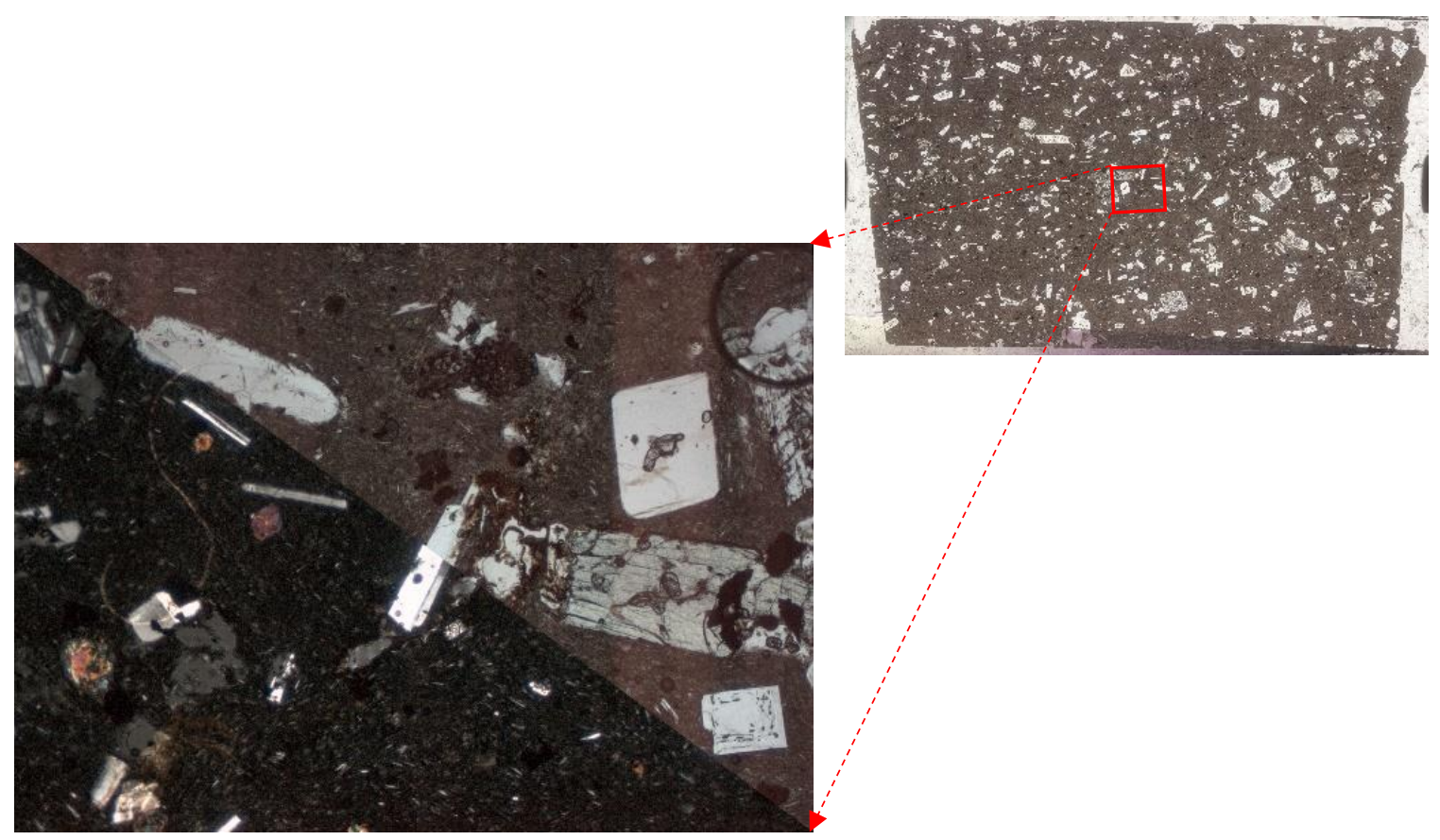

Figure 40: Thin section images of unit 4C (upper right) with highlighted area shown in image under transmitted and cross-polarized light (lower left).

SEM analysis indicates that the analyzed feldspar are $\mathrm{An}_{52}$ plagioclase (Table 9 and Figure 41).

Table 9: Feldspar composition for unit 4C calculated from data obtained by SEM.

\begin{tabular}{lrrr}
\hline $\begin{array}{l}\text { B114 feldspar } \\
\text { population, } \mathrm{n}=10\end{array}$ & Or & Ab & An \\
\hline \hline Mean & 2 & 46 & 52 \\
Minimum & 1 & 37 & 35 \\
Maximum & 4 & 61 & 61 \\
Standard & & & \\
Deviation & 0.85 & 7.61 & 8.35 \\
\hline
\end{tabular}




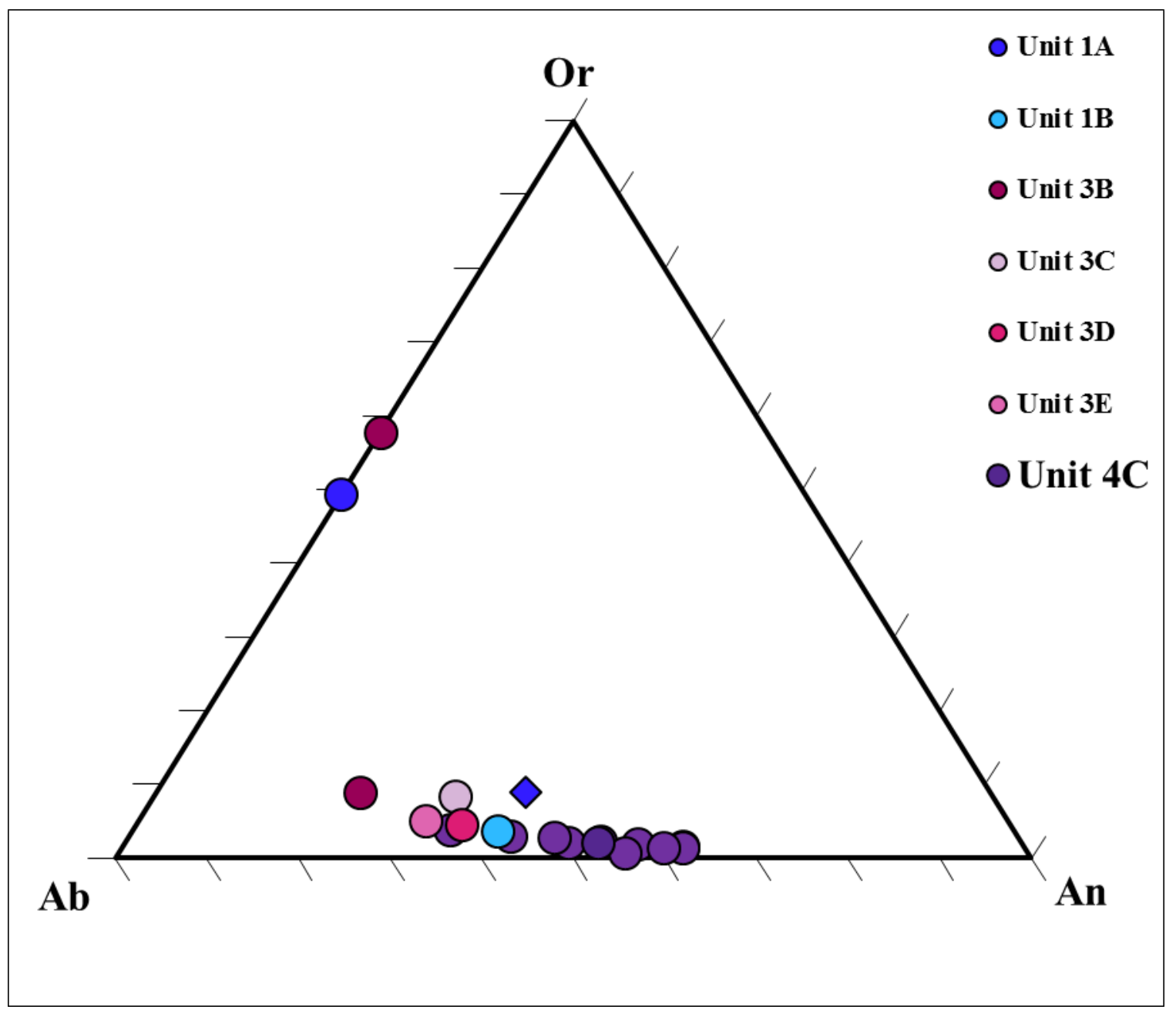

Figure 41: Feldspar ternary plot based on SEM data showing all analysis results for Unit 4C (purple) and averages for all other rhyolite units analyzed.

\section{Area 5:}

\section{Unit 5A}

Macroscopic characteristics: Exposed as obsidian float around the base of a hill and low density boulders and bedrock outcrop forming a hill approximately $1.3 \mathrm{~km}$ south-southeast from Buchanan Springs rest area along highway 20. All samples of this units are vitric and aphyric. 


\section{Unit 5B}

Macroscopic characteristics: Exposed along the Stinkingwater access road approximately $4.5 \mathrm{~km}$ south of highway 20. Outcrops are sparse and occur within a large depression visible in aerial photography (Figure 42).

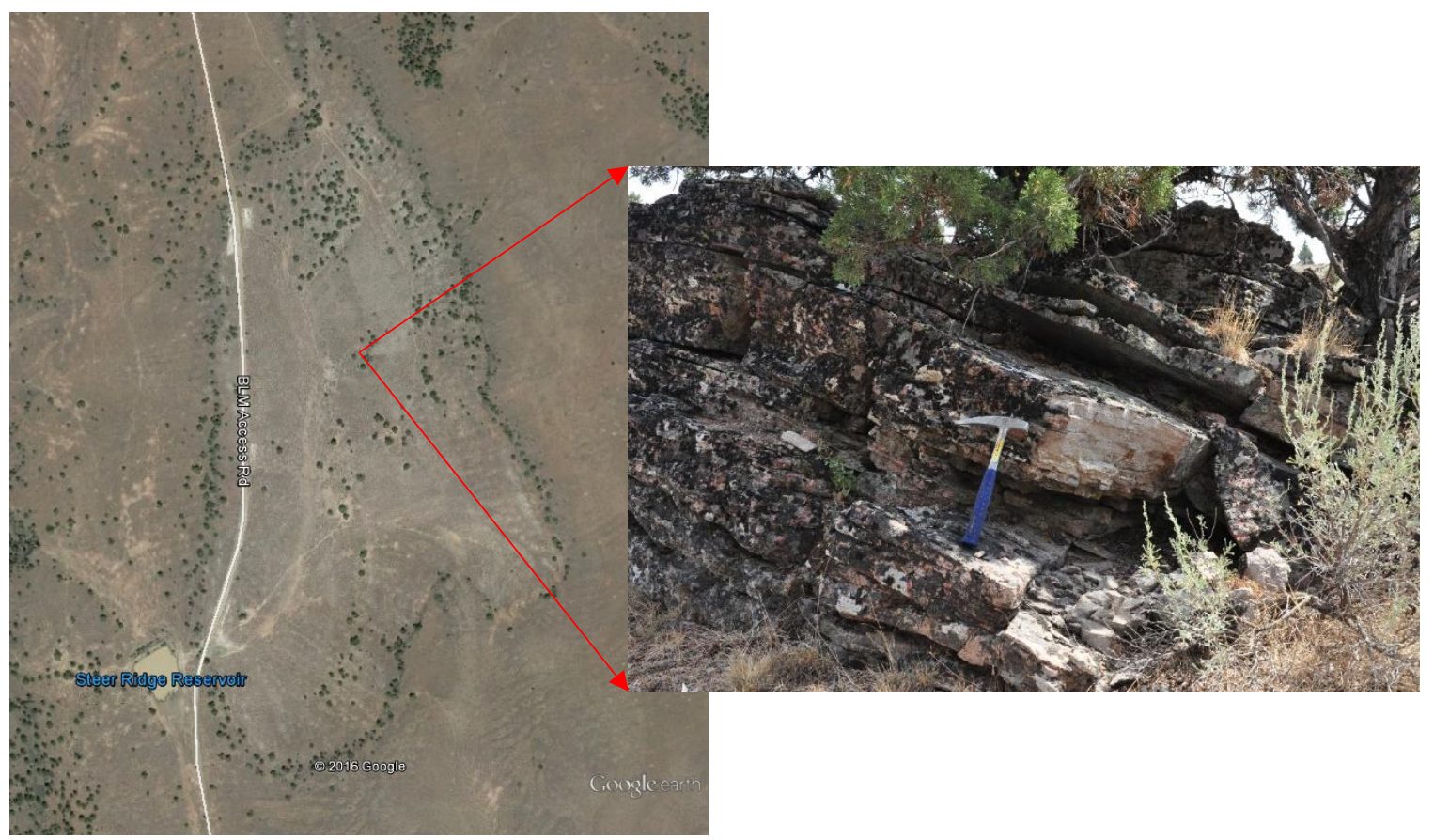

Figure 42: Aerial photograpaph of Area 5B (Google, 2016).

Hand samples are phenocryst poor with color ranging from redish brown to dark gray. Phenocrysts include rounded quartz $<1 \mathrm{~mm}$ and euhedral feldspar $<1 \mathrm{~mm}$. Phenocryst abundance is $<1-3 \%$.

Microscopic characteristics: Phenocryst abundance is approximately $3 \%$ consisting of euhedral plagioclase feldspar (Figure 43). Additional petrographic characteristics are noted in Appendix A-1 for samples B025b. 


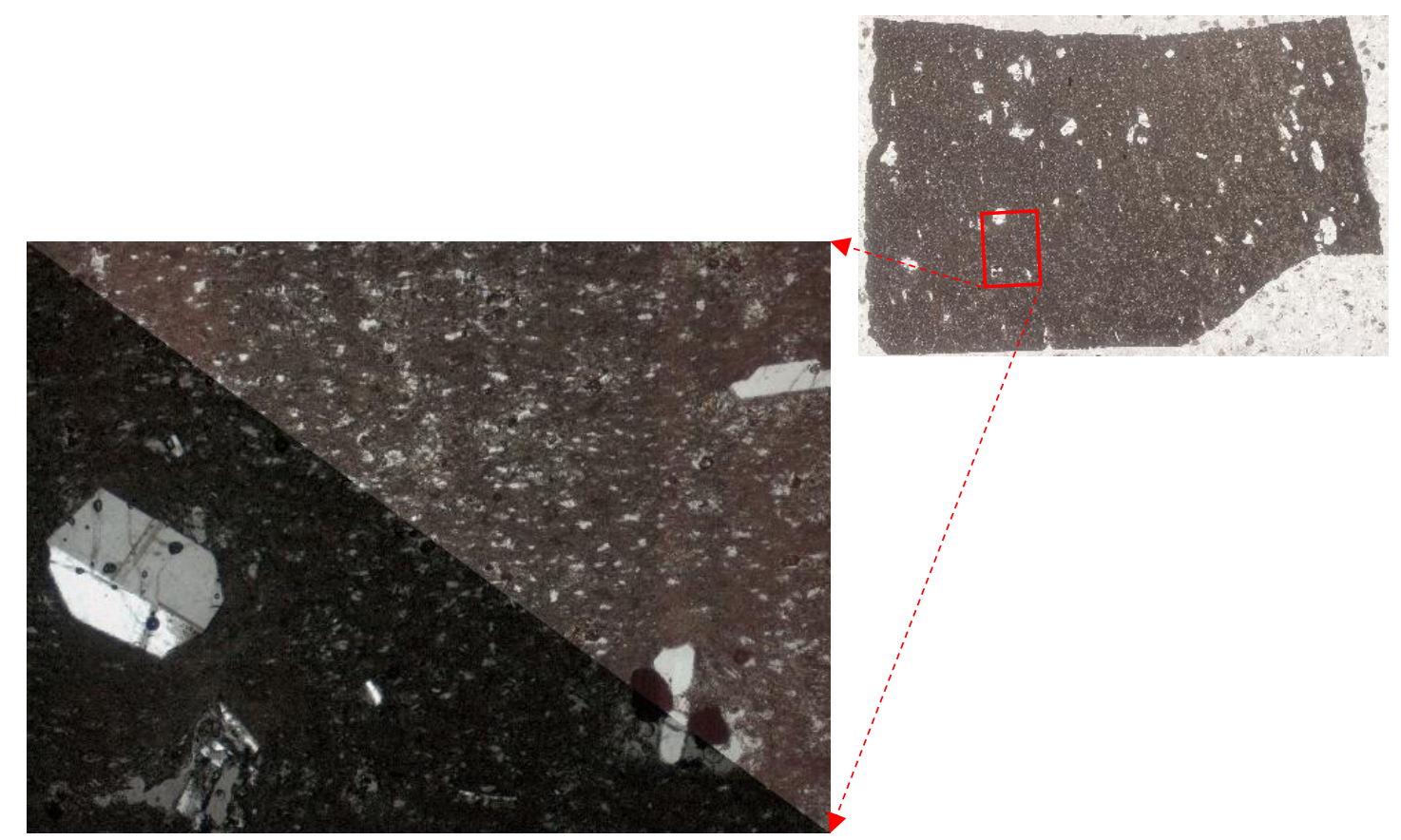

Figure 43: Thin section image of unit 5B (upper right) with highlighted area shown in image under transmitted and cross-polarized light (lower left).

\section{Major and trace element geochemistry}

Bivariate plots of Oxide weight percent (wt\%), trace element concentration and element ratios, as well as multi-element diagrams are used to differentiate and identify geochemical signatures of stratigraphic units. Ratio components are mantle normalized after Sun and McDonough (1989) except Eu/Eu* which use chondrite concentrations after McDonough and Sun (1995) for normalization purposes.

$\mathrm{Ba}^{*}$ is determined by calculating the geometric mean of mantle normalized values of $\mathrm{Rb}$ and $\mathrm{Th}$,

$$
\left(R b_{N_{m}} * T h_{N_{m}}\right)^{1 / 2}
$$

$\mathrm{Sr}^{*}$ is determined by calculating the geometric mean of mantle normalized values of Pr and $\mathrm{Nd}$, 


$$
\left(P r_{N_{m}} * N d_{N_{m}}\right)^{1 / 2}
$$

and $\mathrm{Eu}^{*}$ is determined by calculating the geometric mean of chondrite normalized values of $\mathrm{Sm}$ and $\mathrm{Gd}$ :

$$
\left(S m_{N_{c 1}} * G d_{N_{c 1}}\right)^{1 / 2}
$$

\footnotetext{
Area 1:

As seen in Figure 44, $1 \mathrm{~A}$ has lower total iron as $\mathrm{FeO}(\mathrm{FeO} *)$ and $\mathrm{TiO}_{2}$, lower $\mathrm{Ba}$ and similar concentrations of $\mathrm{Zr}, \mathrm{Nb}$ and $\mathrm{La}$, and lower values of $\mathrm{Eu} / \mathrm{Eu}^{*}$ and $\mathrm{Ba} / \mathrm{Ba}^{*}$ than 1B. Unit 1A feldspar phenocrysts are alkali feldspar while 1B has plagioclase feldspar.
} 

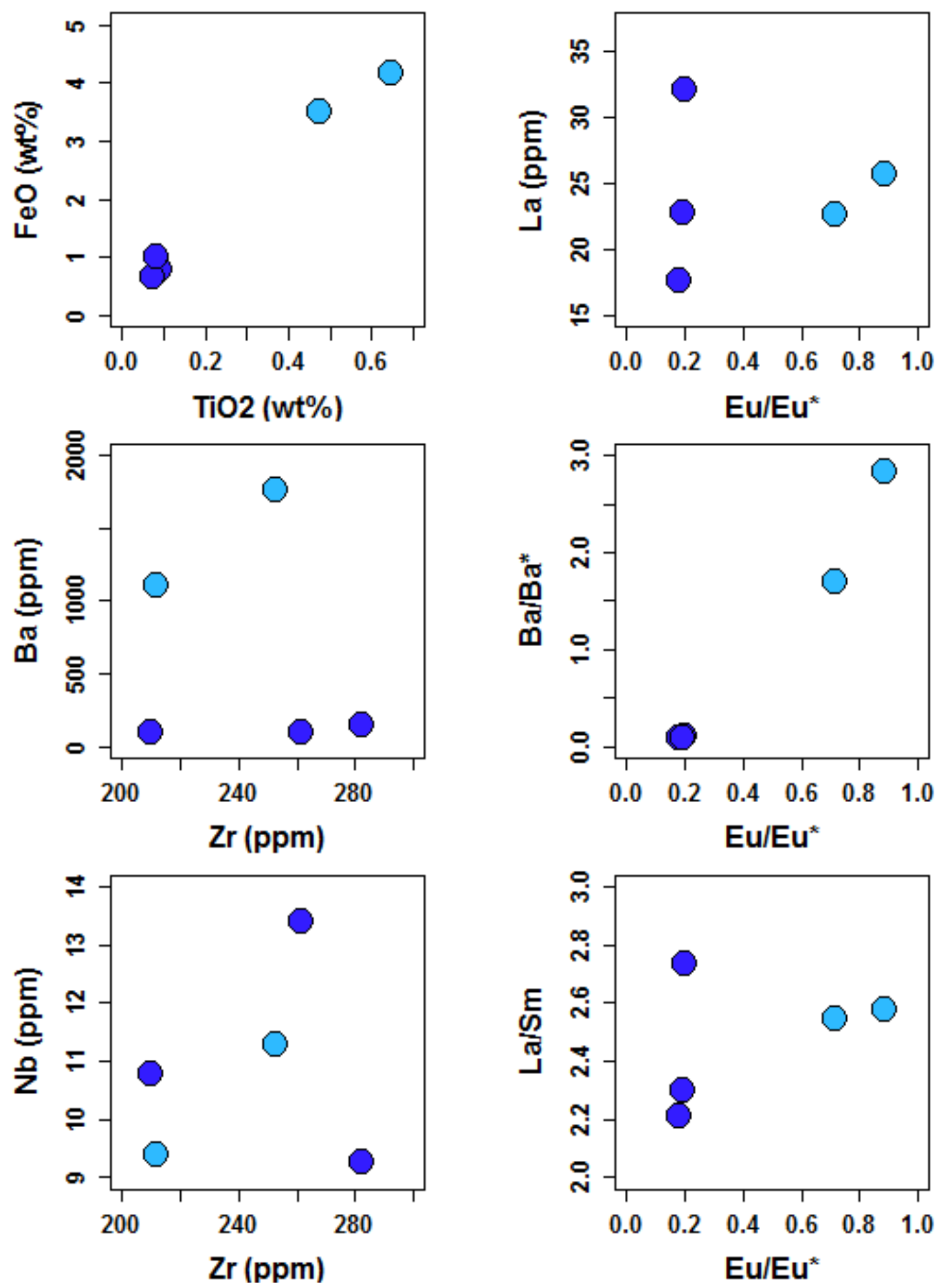

Figure 44: Bivariate plots for units 1A (dark blue) and 1B (light blue). 
Comparison of units 1A and 1B with multi-element diagram (Figure 45) display differences in $\mathrm{Ba}, \mathrm{Sr}, \mathrm{P}, \mathrm{Eu}$ and Ti. Unit $1 \mathrm{~A}$ is more depleted in the former elements than unit $1 \mathrm{~B}$.

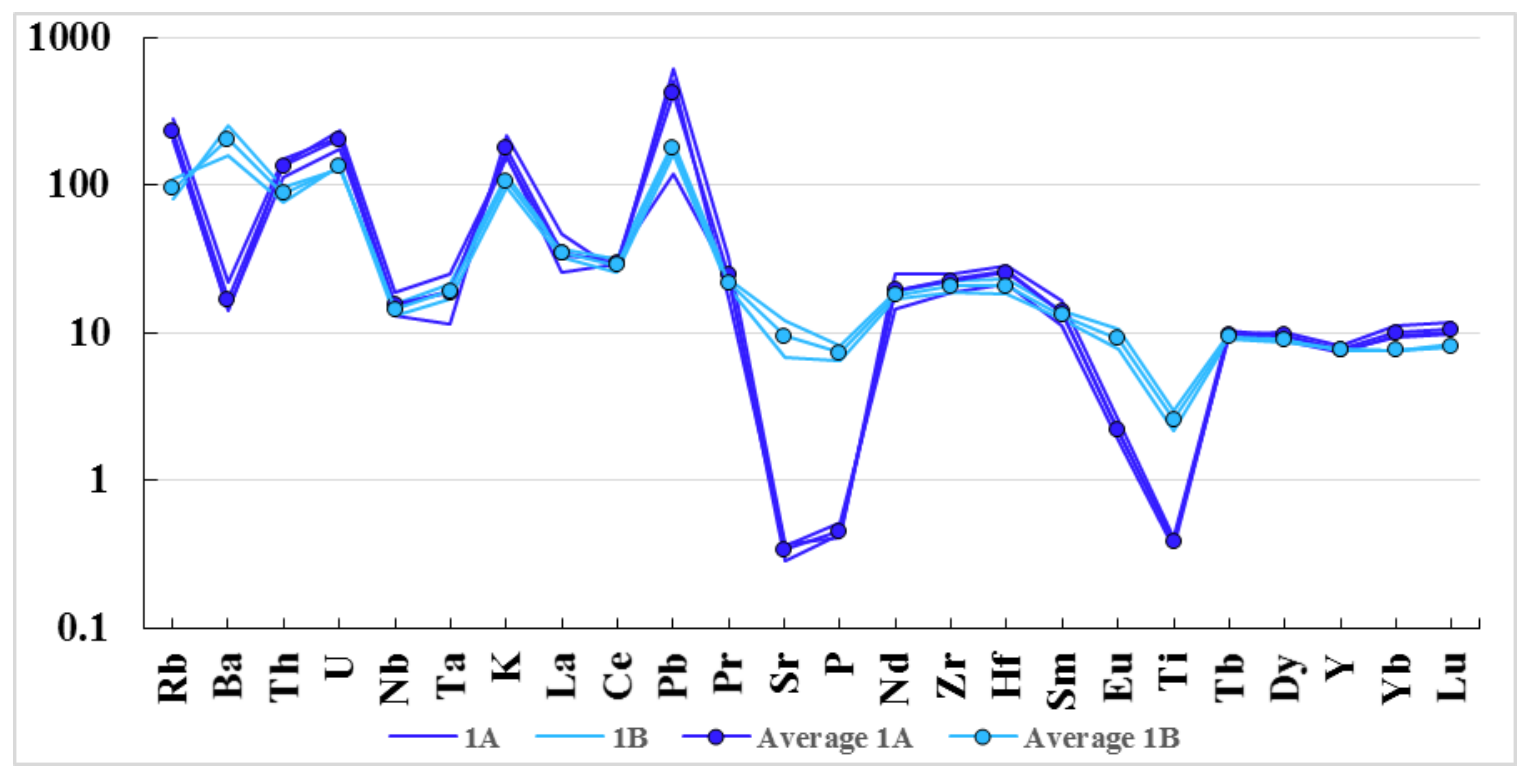

Figure 45: Multi-element diagram for units 1A (dark blue) and 1B (light blue). Concentrations normalized to mantle values of Sun and McDonough (1989)

\section{Area 2:}

The two units of Area 2 can be differentiated geochemically based on their major and trace elemental composition (Figure 46 and 47). Unit 2A has higher FeO* compared to 2B; $2 \mathrm{~A}$ has slightly lower $\mathrm{Zr}$ and $\mathrm{Nb}$, and higher $\mathrm{Ba}$ and $\mathrm{La}$ than 2B. 2A has slightly lower $\mathrm{Eu} / \mathrm{Eu}$ *, higher $\mathrm{La} / \mathrm{Sm}$ and lower $\mathrm{Ba} / \mathrm{Ba}^{*}$ than $2 \mathrm{~B}$. 

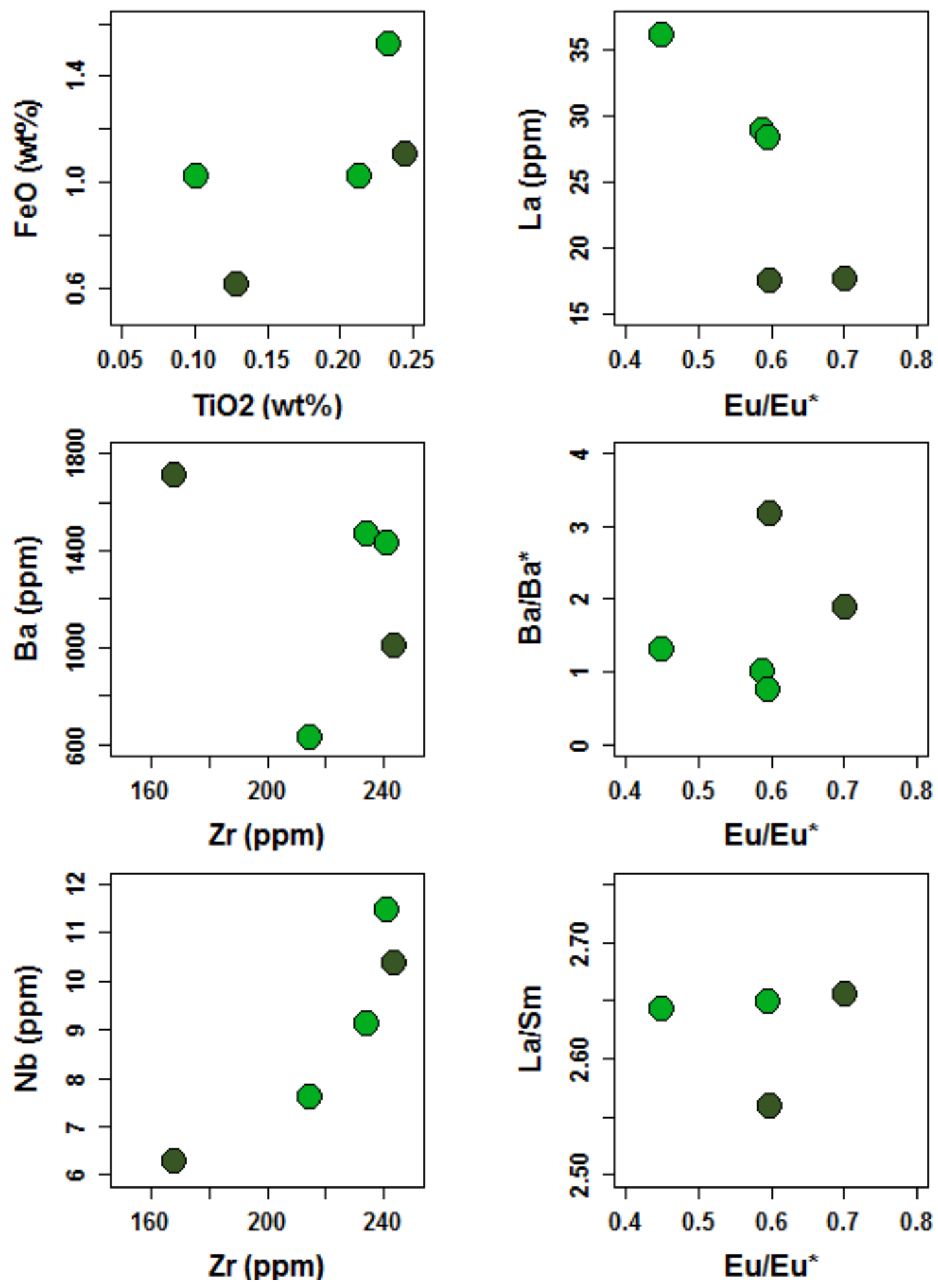

Figure 46: Bivariate plots for units 2A (light green) and 2B (dark green). 
Comparison of units 2A and 2B with multi-element diagram (Figure 47) display greater overall enrichment in unit 2A compared to unit 2B. Notable are higher HREE in $2 \mathrm{~A}, \mathrm{P}$ trough in $2 \mathrm{~B}$, higher $\mathrm{Sr}$ in $2 \mathrm{~B}$, and contrasting pattern from $\mathrm{Rb}$ to $\mathrm{U}$ between the two units.

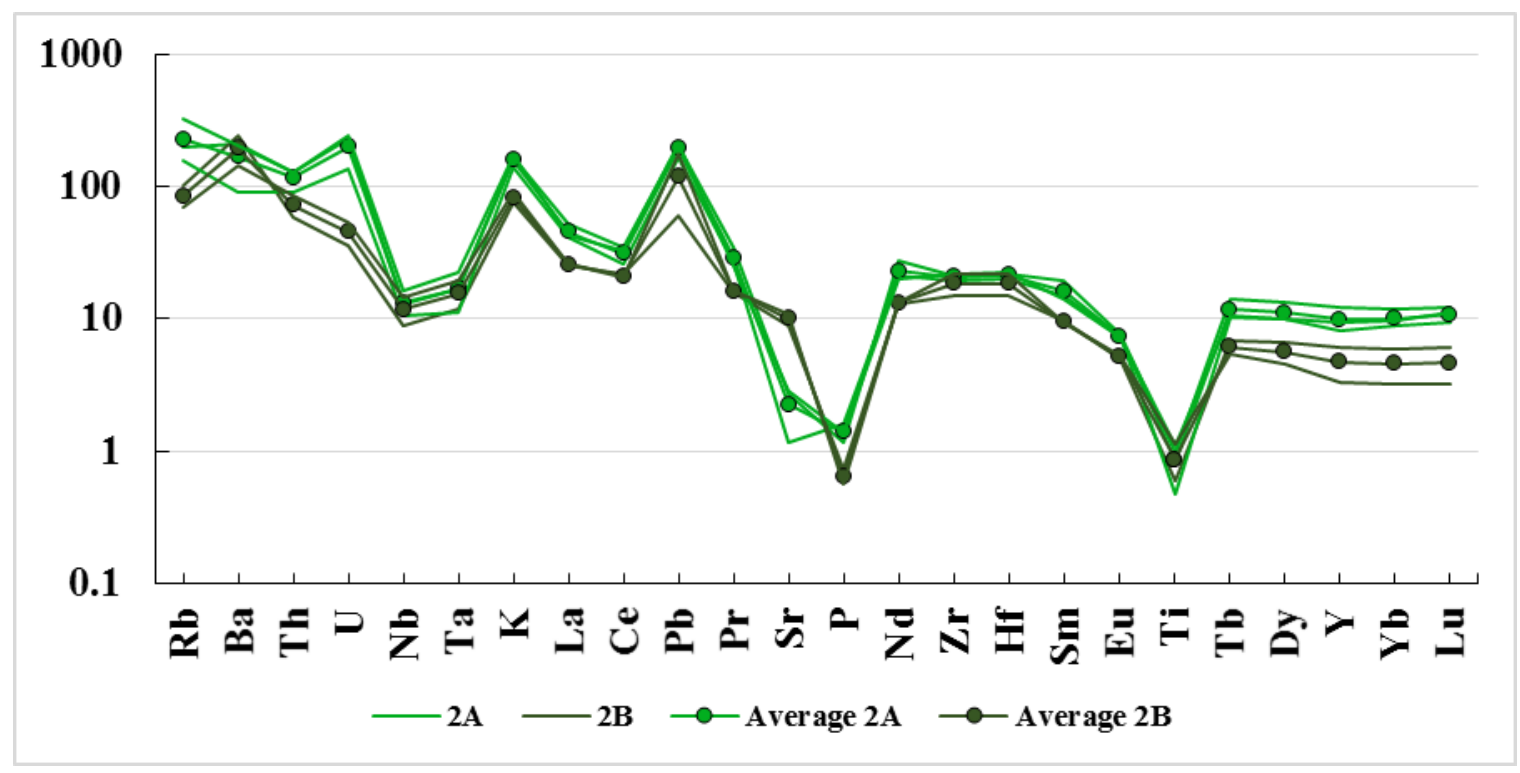

Figure 47: Multi-element diagram for units 2A (light green) and 2B (dark green). Concentrations normalized to mantle values of Sun and McDonough (1989)

\section{Area 3:}

The six rhyolitic stratigraphic units of area 3 indicate subtle compositional differences and thus can be differentiated geochemically. These six units are presented in groups of two units in each plot to provide clarity in presentation of data. Mafic unit b3A is differentiated following the rhyolites of area 5 along with mafic units b4A, b4B and MS-13-SWB. 


\section{Units 3A and 3B}
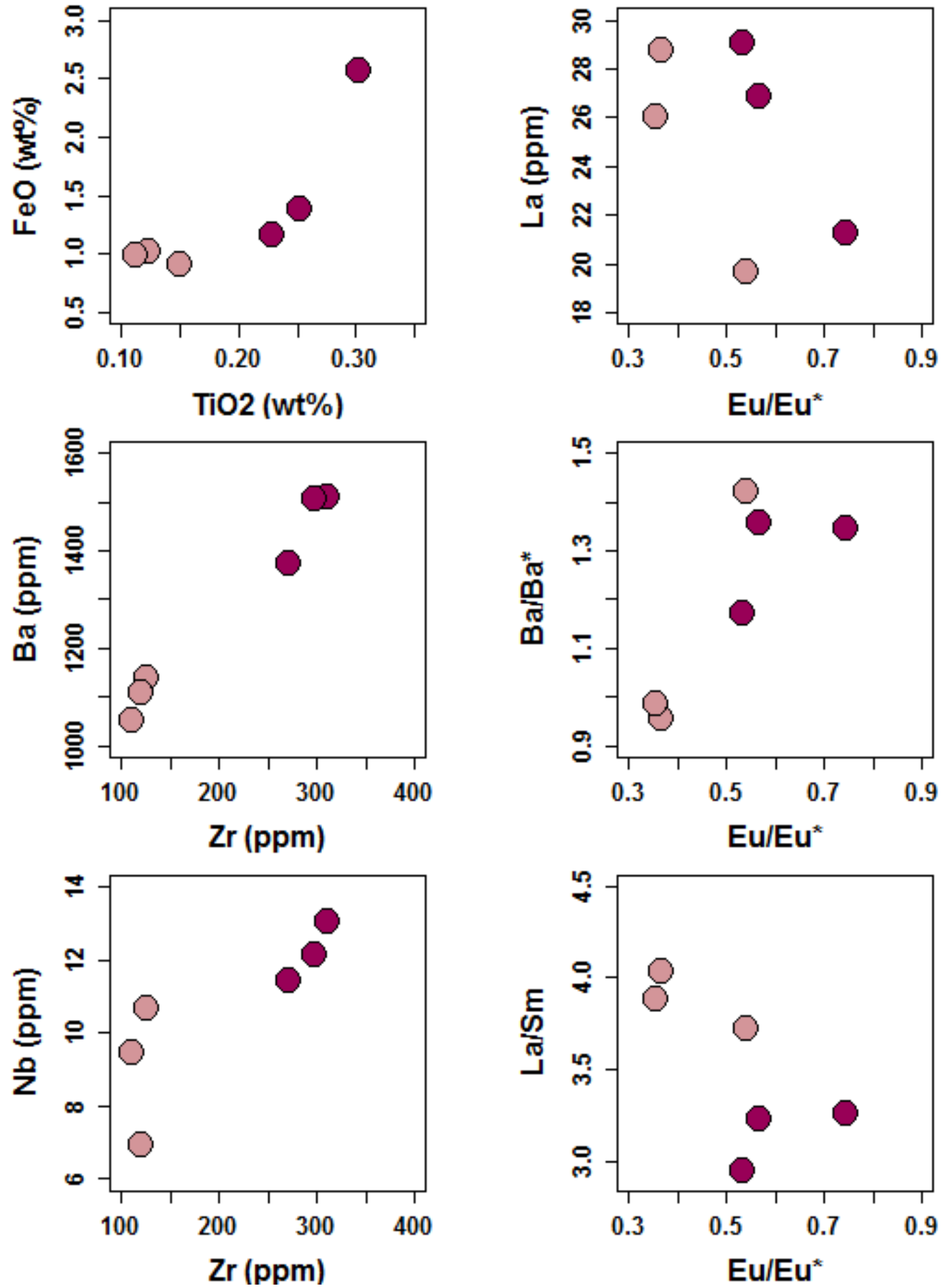

Figure 48: Bivariate plots for units 3A (light pink) and 3B (dark pink). 
The two stratigraphic units, 3A and 3B, show subtle differences on major and trace element plots (Figure 48 and 49); 3A has lower $\mathrm{TiO}_{2}$, $\mathrm{Ba}$, and $\mathrm{Nb}$ compared to 3B. 3A has lower $\mathrm{Eu} / \mathrm{Eu}$ *, higher $\mathrm{La} / \mathrm{Sm}$ and lower $\mathrm{Ba} / \mathrm{Ba}^{*}$ than $3 \mathrm{~B}$. Outliers in the diagrams may be due to element mobility during devitrification and/or alteration.

Comparison of units $3 \mathrm{~A}$ and $3 \mathrm{~B}$ with multi-element diagram (Figure 49) shows similar enrichment in $\mathrm{Rb}-\mathrm{Sr}$, and slightly greater enrichment in $\mathrm{P}-\mathrm{Lu}$ in unit 3B. Principle differences in enrichment are in $\mathrm{Zr}$ and $\mathrm{Hf}$ whereas the crystal poor unit $3 \mathrm{~A}$ has less enrichment than the crystal rich unit 3B.

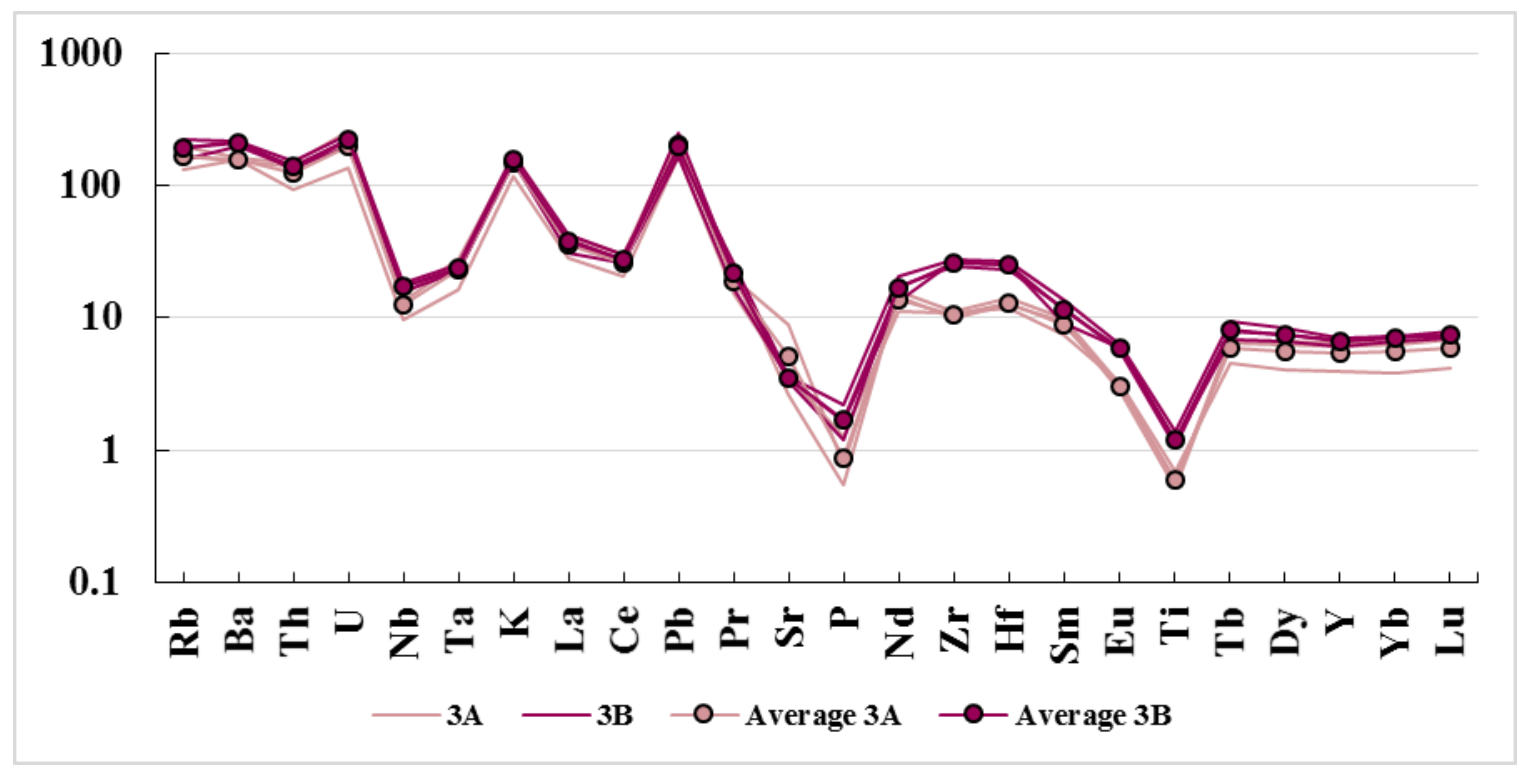

Figure 49: Multi-element diagram for units 3A (light pink) and 3B (dark pink). Concentrations normalized to mantle values of Sun and McDonough (1989)

\section{Units 3C and 3D}

Comparing units $3 \mathrm{C}$ and 3D (Figure 50), $3 \mathrm{C}$ has higher $\mathrm{FeO}^{*}$ and $\mathrm{TiO}_{2}$ compared to 3D. 3C has lower $\mathrm{Zr}, \mathrm{Ba}, \mathrm{Nb}$ and $\mathrm{La}$ than $3 \mathrm{D}$. 3C has slightly higher Eu/Eu*, slightly lower $\mathrm{La} / \mathrm{Sm}$ and lower $\mathrm{Ba} / \mathrm{Ba}^{*}$ than $3 \mathrm{D}$. 

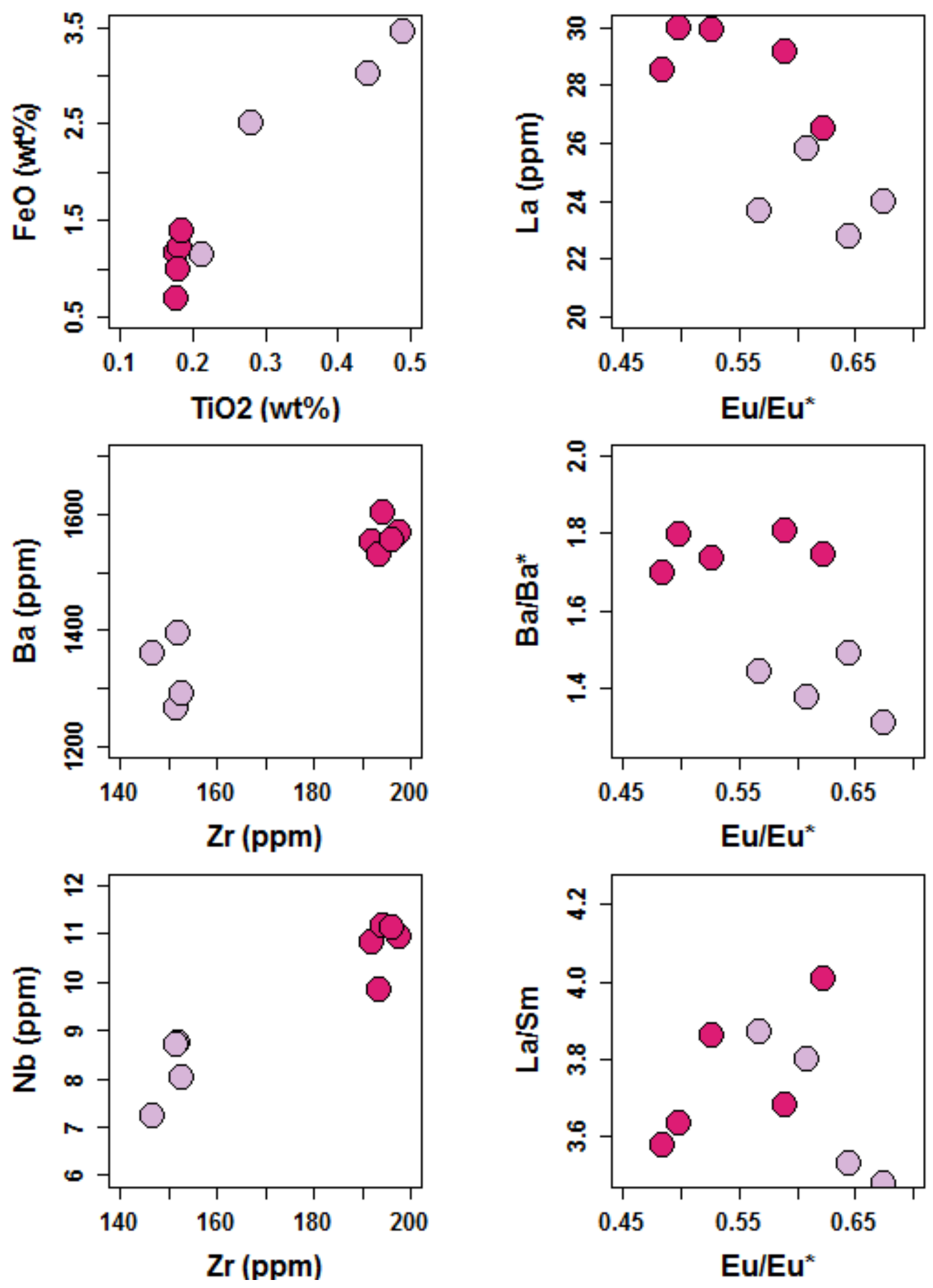

Figure 50: Bivariate plots for units 3C (light pink) and 3D (bright pink). 
Comparison of units 3C and 3D with multi-element diagram (Figure 51) show similar enrichment in both LIL and HFS elements. Unit 3C is more enriched in $\mathrm{Sr}, \mathrm{P}$ and $\mathrm{Ti}$ and less enriched in $\mathrm{Zr}$ and $\mathrm{Hf}$ than unit 3D.

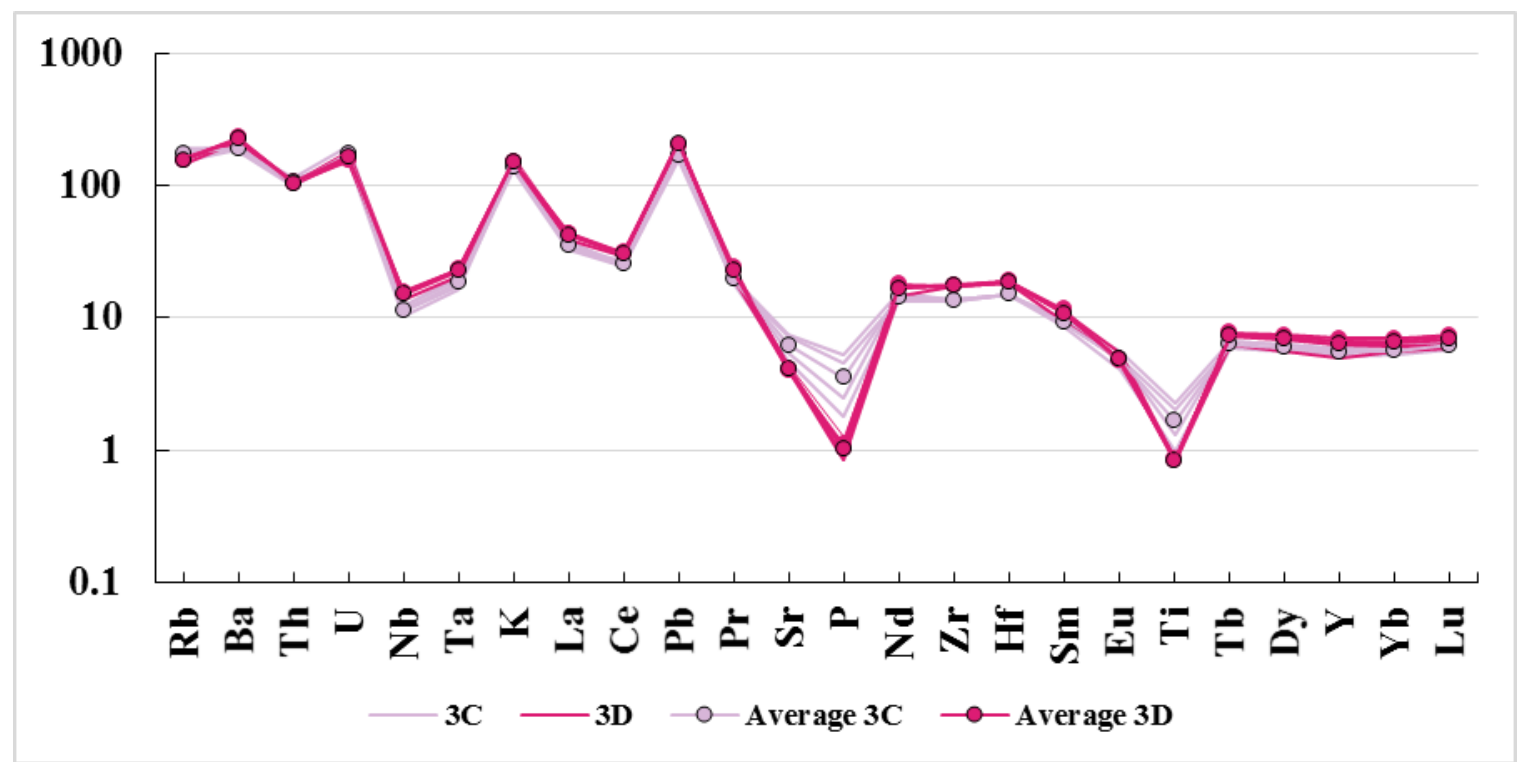

Figure 51: Multi-element diagram of units 3C (light pink) and 3D (bright pink). Concentrations normalized to mantle values of Sun and McDonough (1989)

\section{Units $3 E$ and $3 F$}

As seen in Figure 52, 3E has lower $\mathrm{FeO}^{*}$ and $\mathrm{TiO} 2$ compared to 3F. 3E has lower $\mathrm{Zr}, \mathrm{Nb}$ and $\mathrm{La}$, and higher $\mathrm{Ba}$ than $3 \mathrm{~F}$ (one outlier value in unit $3 \mathrm{~F}$ of $\mathrm{Ba}$ greater than $3 \mathrm{E}$ ). 3E has lower $\mathrm{Eu} / \mathrm{Eu}^{*}$, higher $\mathrm{La} / \mathrm{Sm}$ and lower $\mathrm{Ba} / \mathrm{Ba}^{*}$ than $3 \mathrm{~F}$. 

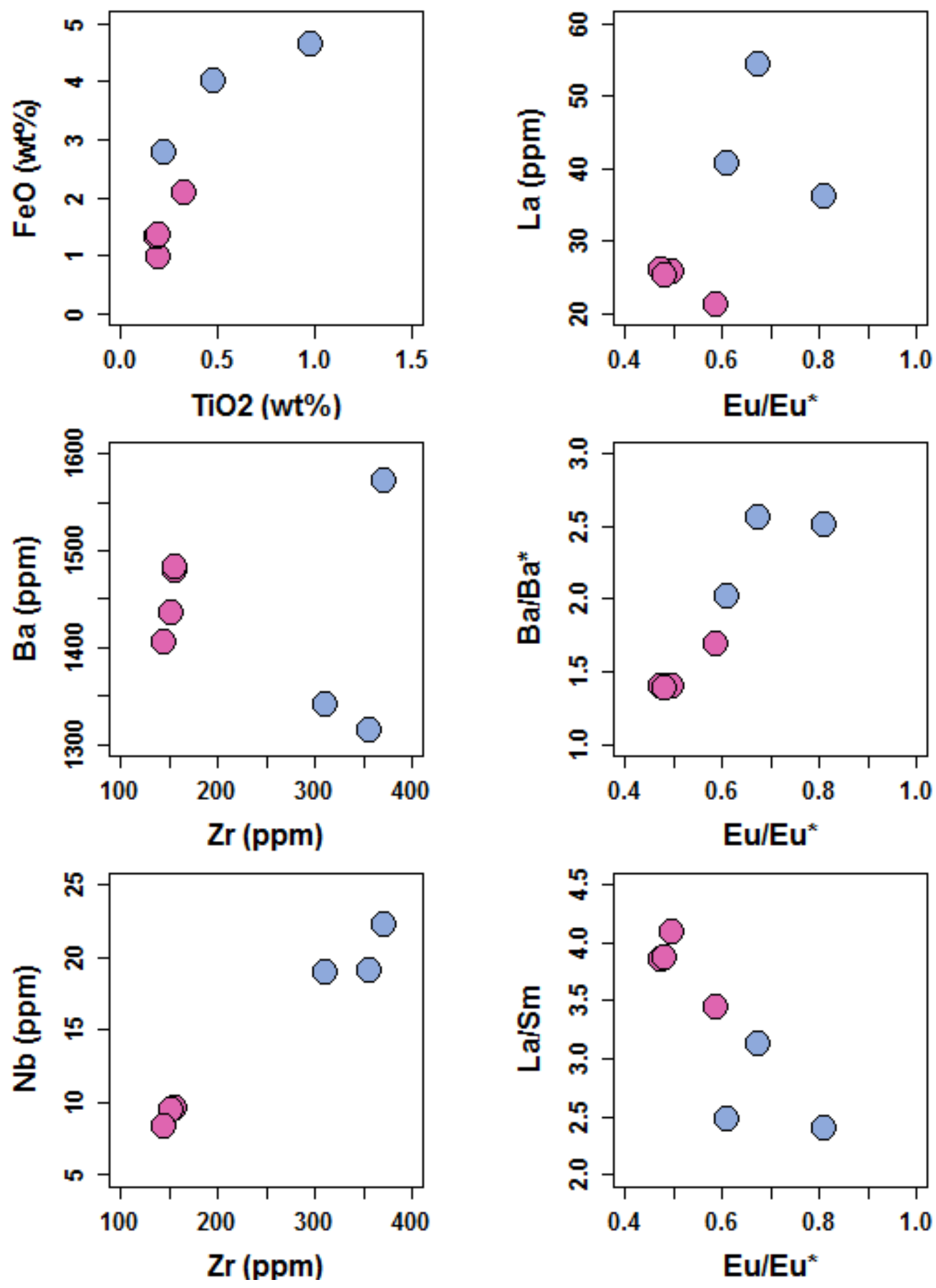

Figure 52: Bivariate plots for units 3E (pink) and 3F (light blue). 
Comparison of units $3 \mathrm{E}$ and $3 \mathrm{~F}$ with multi-element diagram (Figure 53) show greater enrichment in most elements of $3 \mathrm{~F}$ than $3 \mathrm{E}$. 3F has less enrichment than $3 \mathrm{E}$ for elements $\mathrm{Rb}$, Th and $\mathrm{U}$, and similar enrichment for $\mathrm{K}$ and $\mathrm{Pb}$.

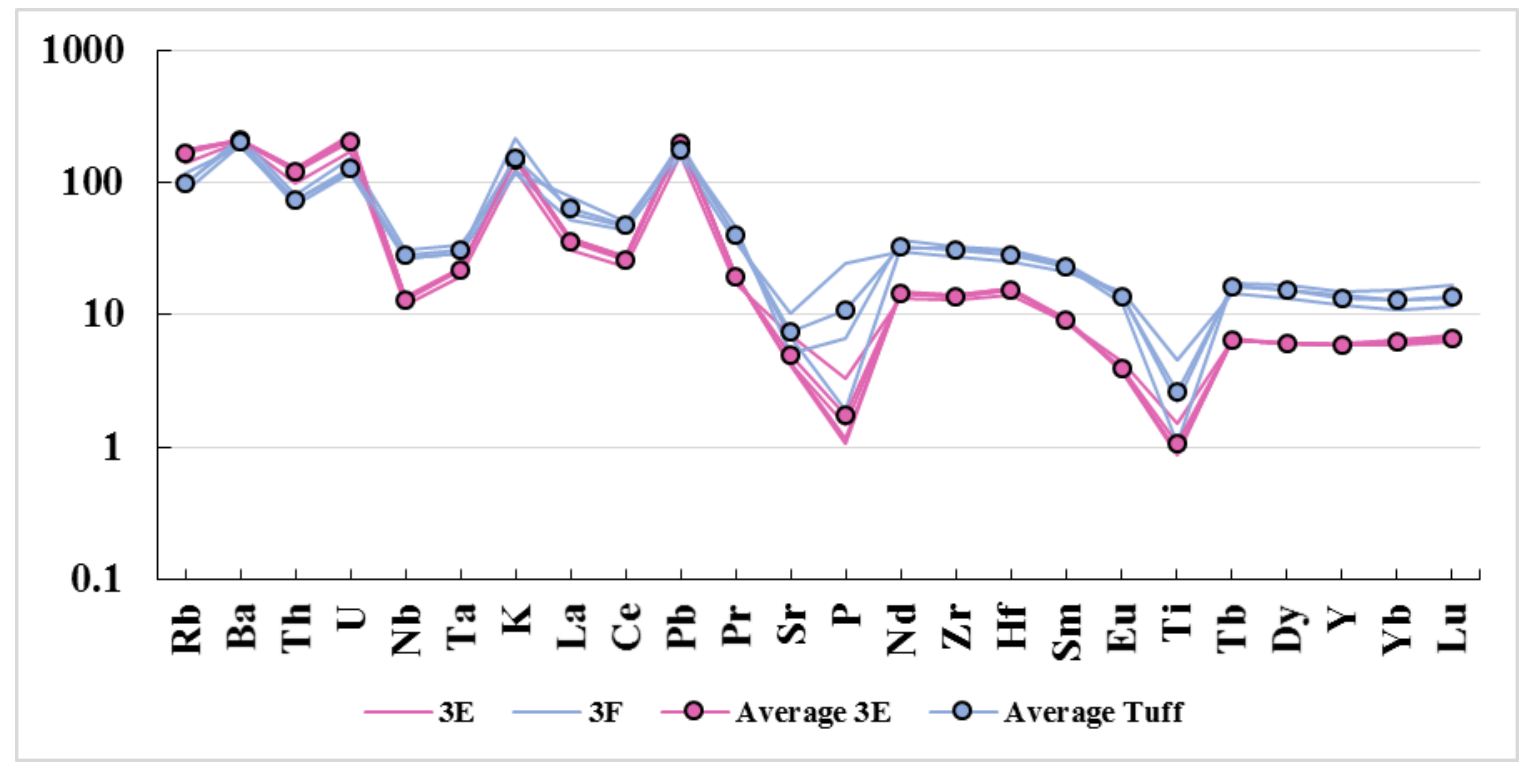

Figure 53: Multi-element diagram of units 3E (pink) and 3F (light blue). Concentrations normalized to mantle values of Sun and McDonough (1989)

\section{Unit 3A-3F averages}

Comparison of average values for area 3 units with multi-element diagram (Figure 54) show notable differences. Unit 3F is distinctly different than units $3 \mathrm{~A}-3 \mathrm{E}$. Units 3A-3E have similar patterns with slight differences seen in $\mathrm{Sr}, \mathrm{P}, \mathrm{Zr}, \mathrm{Hf}$ and $\mathrm{Ti}$. The differences are emphasized in Figure 55. 


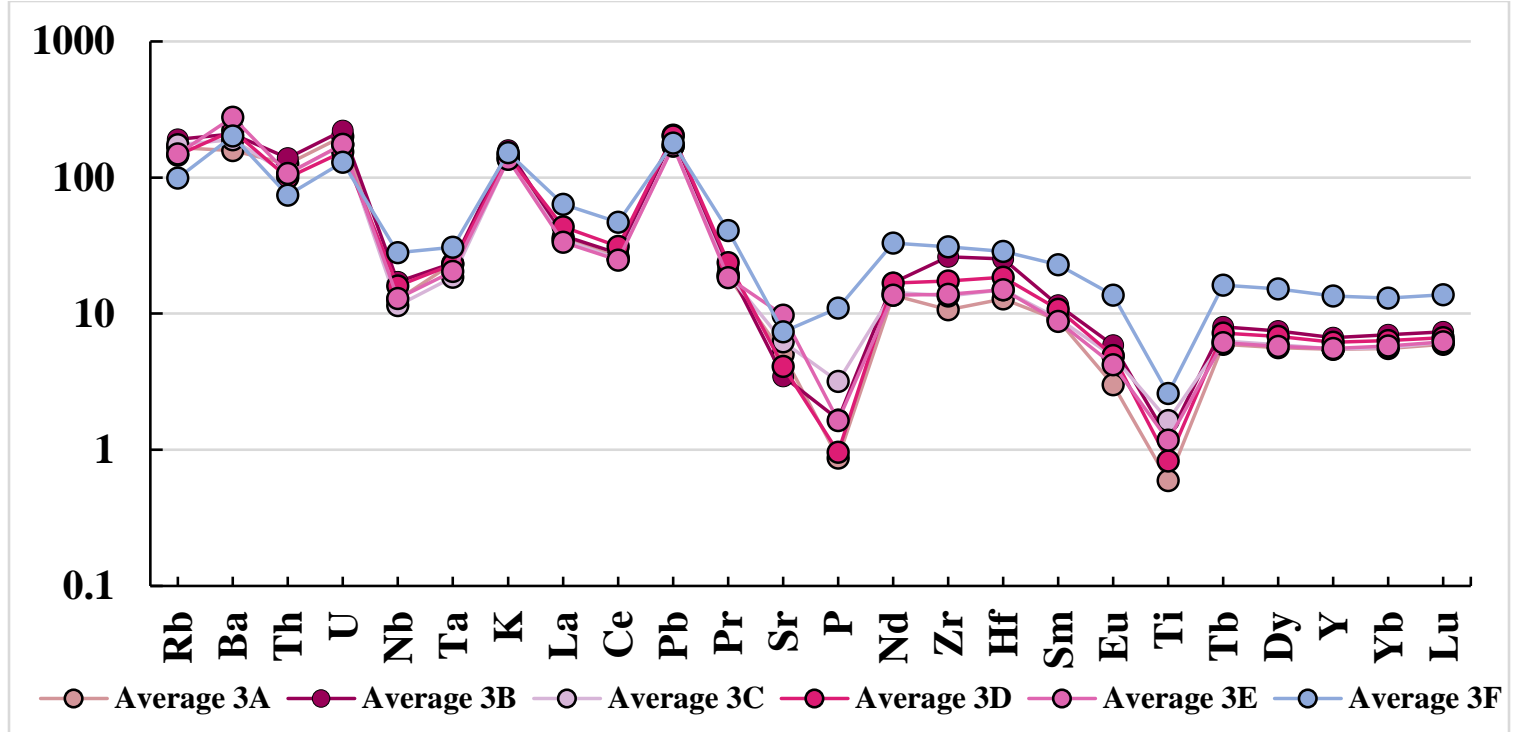

Figure 54: Multi-element diagram of all average values of area 3 units. Concentrations normalized to mantle values of Sun and McDonough (1989)

Overall depletion relative to other elements of $\mathrm{Sr}$ for units $3 \mathrm{~A}-3 \mathrm{E}$ from greatest to least depleted is: 3B, 3D, 3A, 3C, 3E. Depletion of $\mathrm{P}$ and Ti from greatest to least is: $3 \mathrm{~A}$, 3D, 3E, 3B, 3C. Enrichment of $\mathrm{Zr}$ and $\mathrm{Hf}$ from greatest to least is: 3A, 3E, C, 3D, 3B.

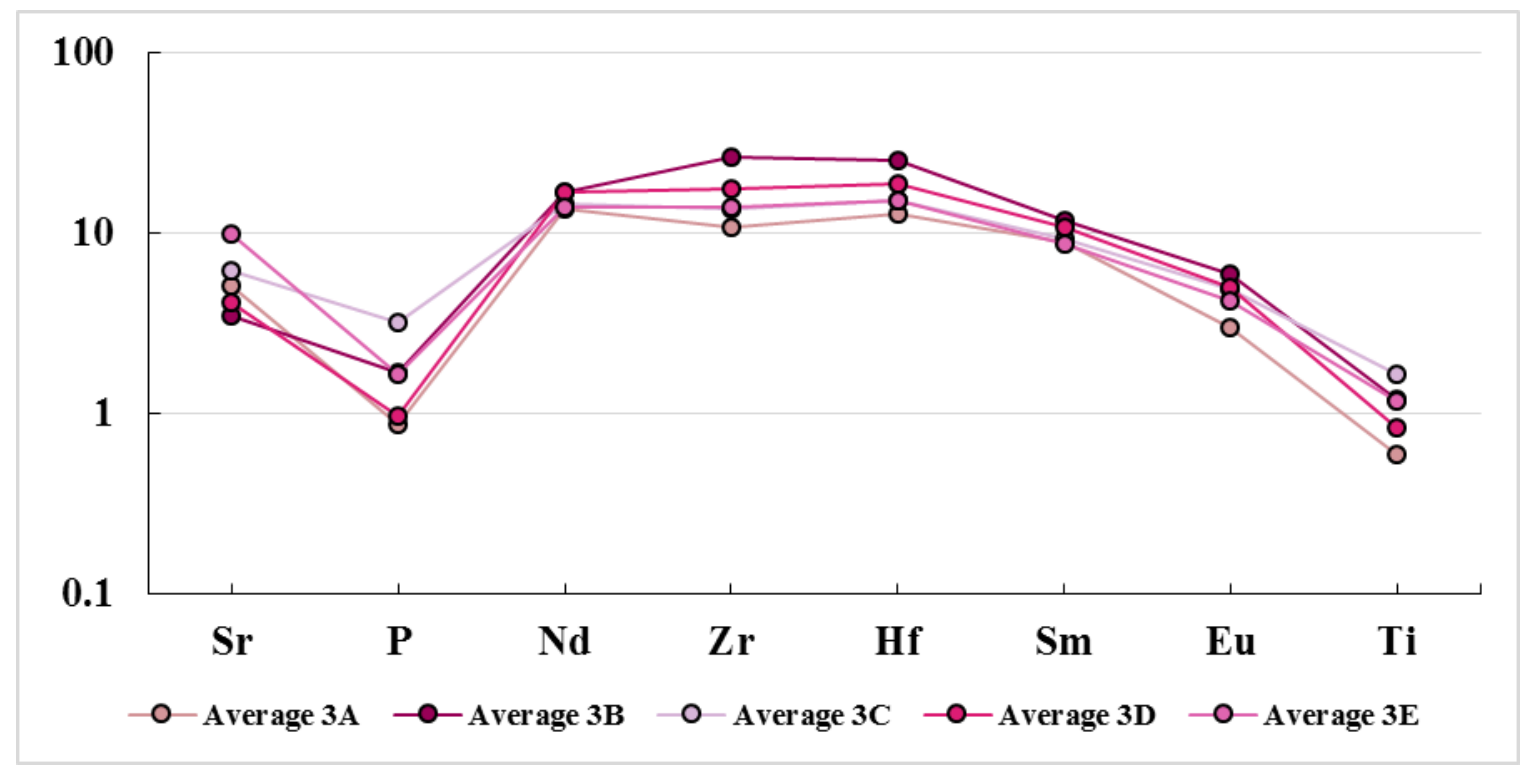

Figure 55: Part of multi-element diagram displaying average values of area 3 units. Concentrations normalized to mantle values of Sun and McDonough (1989) 


\section{Area 4:}

The 5 stratigraphic units in area 4 are made up of two main two groups: rhyolitic units 4A-4C and basaltic andesite and basalt units b4A, b4B and MS-13-SWB. The mafic units are differentiated following the rhyolites of area 5 along with unit b3A.

\section{Units 4A, 4B and 4C}

Three rhyolitic stratigraphic units of area 4 are differentiated with Figure 56 and 57. 4A has higher $\mathrm{FeO}^{*}$ and $\mathrm{TiO} 2$ compared to $4 \mathrm{~B}$ and lower $\mathrm{FeO}^{*}$ and $\mathrm{TiO}_{2}$ compared to 4C. 4A has higher $\mathrm{Zr}, \mathrm{Nb}$ and $\mathrm{Ba}$, and lower La compared to 4B. 4A has higher $\mathrm{Nb}$ and $\mathrm{Ba}$, and similar $\mathrm{Zr}$ and La compared to 4C. 4A has higher $\mathrm{Eu} / \mathrm{Eu}^{*}$, similar $\mathrm{La} / \mathrm{Sm}$ and higher $\mathrm{Ba} / \mathrm{Ba}^{*}$ compared to $4 \mathrm{~B}$. 4A has similar $\mathrm{Eu} / \mathrm{Eu}$ *, higher $\mathrm{La} / \mathrm{Sm}$ and lower $\mathrm{Ba} / \mathrm{Ba}^{*}$ compared to $4 \mathrm{C}$. 

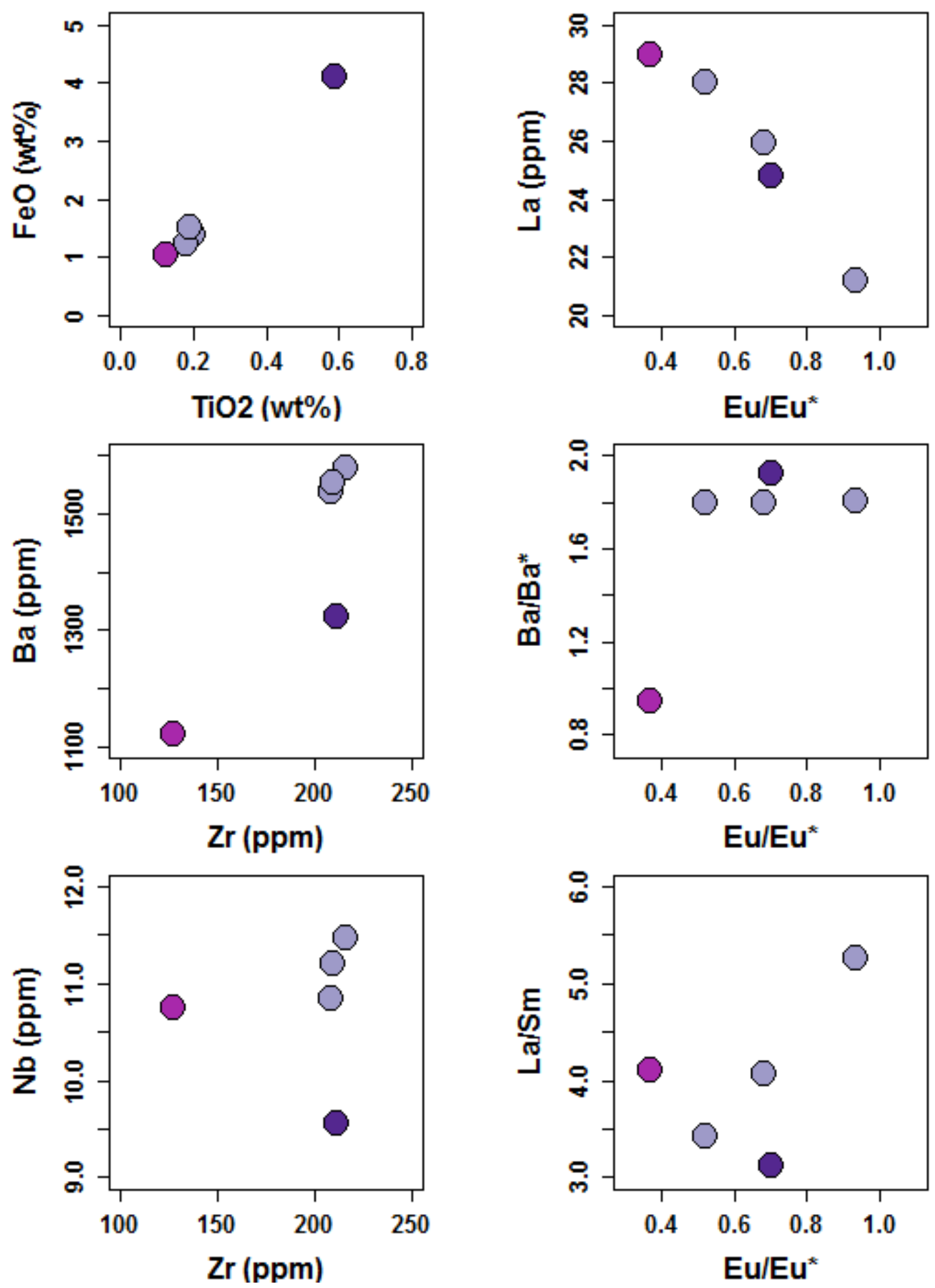

Figure 56: Bivariate plots for units 4A (lavender), 4B(dark pink) and 4C (dark purple). 
Comparison of units 4A-4C with multi-element diagram (Figure 57) shows 4A differs from $4 \mathrm{~B}$ in $\mathrm{Ba}$ whereas $4 \mathrm{~A}$ has a positive $\mathrm{Ba}$ spike and $4 \mathrm{~B}$ has a slight negative trend. Similarly 4A has more enrichment in $\mathrm{Zr}$ and $\mathrm{Hf}$ than $4 \mathrm{~B} .4 \mathrm{C}$ is similar to $4 \mathrm{~A}$ in $\mathrm{LIL}$ elements and slighly more enriched in HFS elements with Sr, P and Ti being considerably more enriched.

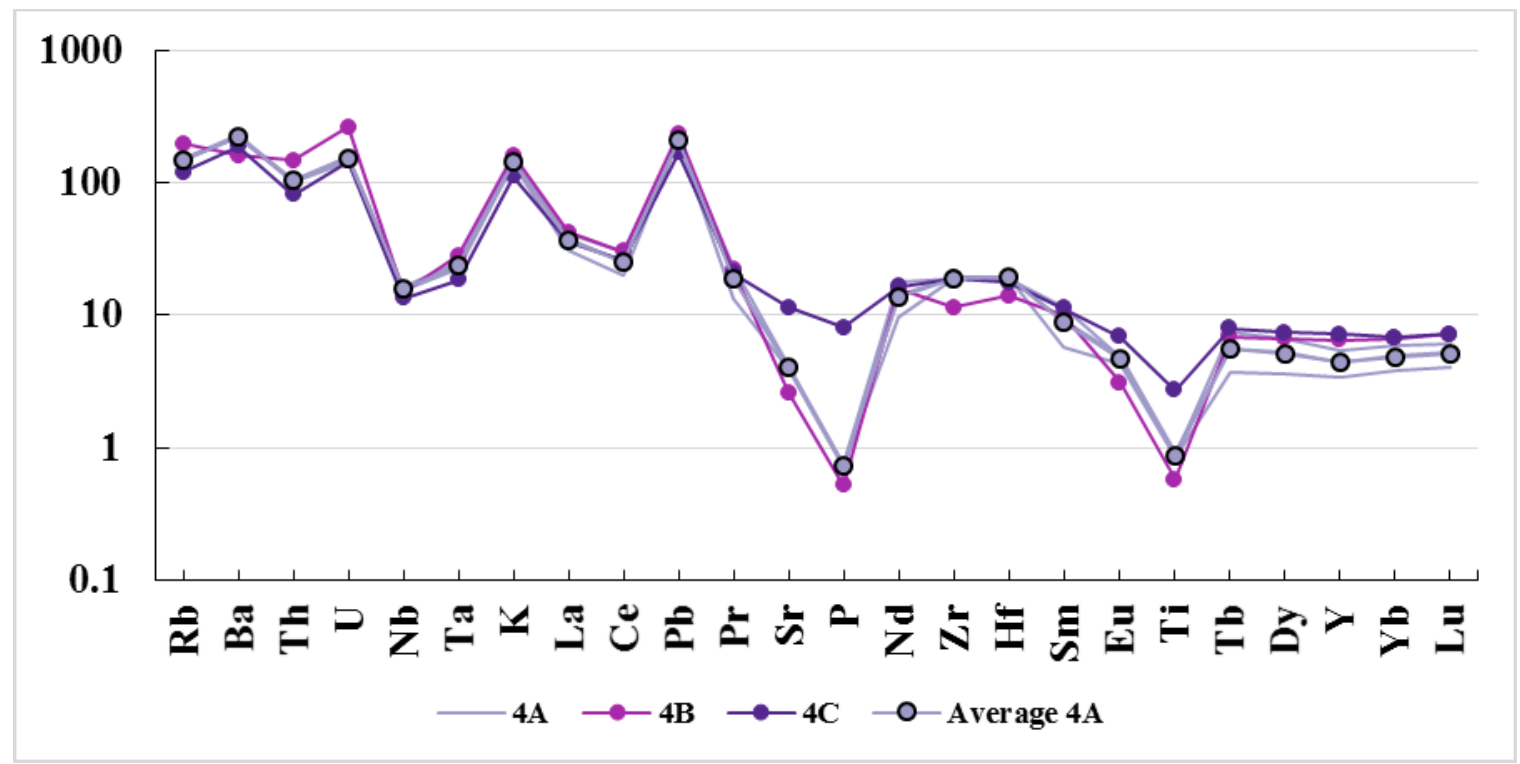

Figure 57: Multi-element diagram of units 4A (lavender), 4B (dark pink) and 4C (purple). Concentrations normalized to mantle values of Sun and McDonough (1989)

\section{Area 5:}

Figure 58 shows the geochemical trends of the two units in Area 5. 5A has lower $\mathrm{Zr}, \mathrm{Nb}$ and $\mathrm{La}$, and slightly higher $\mathrm{Ba}$ than 5B. 5A has slightly lower $\mathrm{Eu} / \mathrm{Eu}^{*}$ and $\mathrm{Ba} / \mathrm{Ba}^{*}$, and slightly higher La/Sm compared to 5B. 

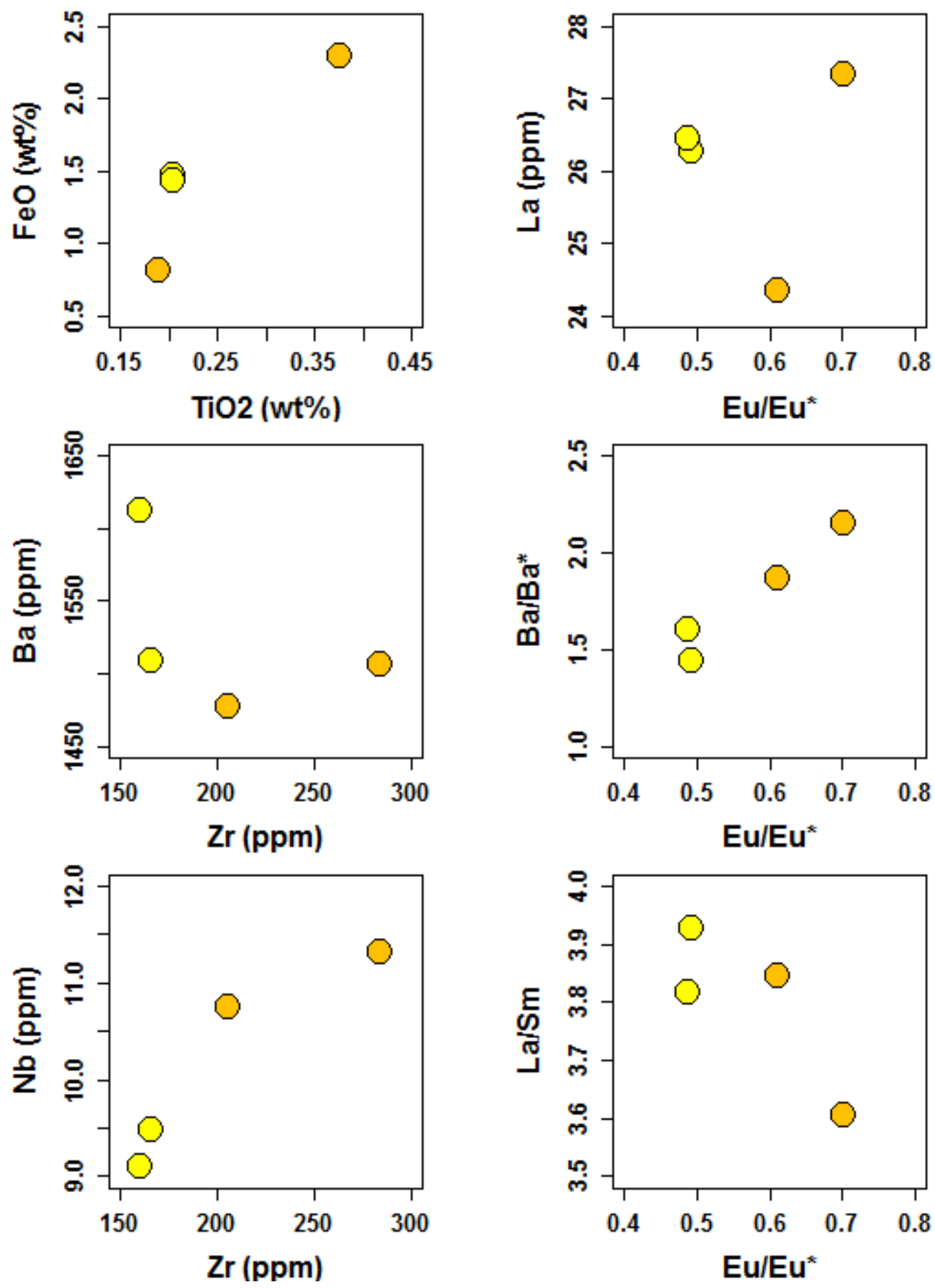

Figure 58: Bivariate plots for units 5A (bright yellow) and 5B (orange). 
Units 5A and 5B display similar overall enrichment in units (Figure 59); however, unit 5B has slightly greater enrichment in $\mathrm{Zr}$ and $\mathrm{Hf}$ than unit 5A.

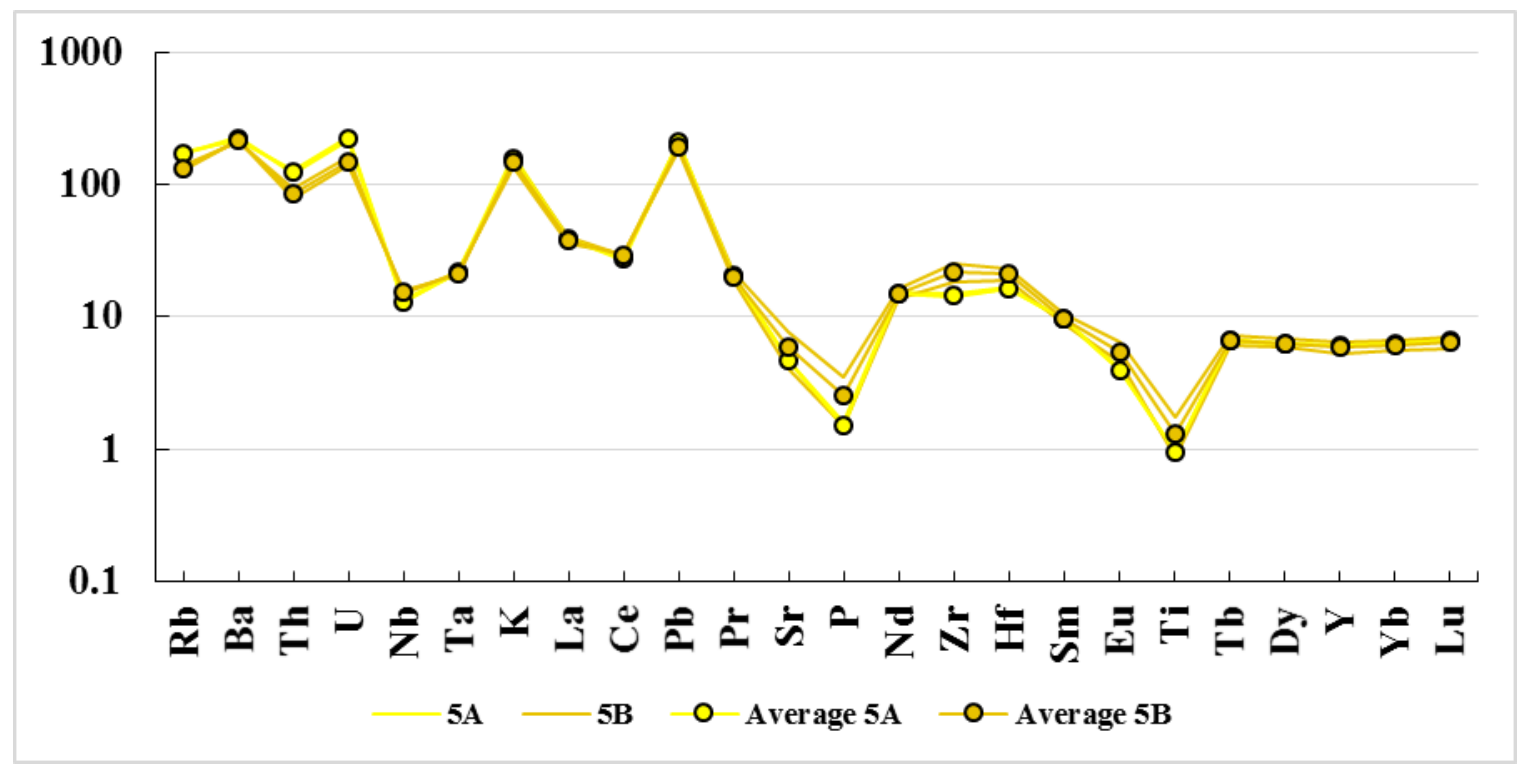

Figure 59: Multi-element diagram of units 5A (bright yellow), and 5B (orange). Concentrations normalized to mantle values of Sun and McDonough (1989)

\section{Mafic Units b3A, b4A, b4B and MS-13-SWB}

Figure 60 shows that $\mathrm{b} 3 \mathrm{~A}$ and $\mathrm{b} 4 \mathrm{~A}$ have lower $\mathrm{FeO} *$ and $\mathrm{TiO} 2$ compared to $\mathrm{b} 4 \mathrm{~B}$ and MS-13-SWB. Units b3A and b4A also have lower Zr, Nb, Ba and La compared to b4B, and lower $\mathrm{Zr}, \mathrm{Nb}$ and $\mathrm{La}$, and slightly higher Ba compared to MS-13-SWB. Unit b4B has slightly higher Zr, lower Nb and higher Ba than MS-13-SWB. Units b3A and b4A have lower $\mathrm{Eu} / \mathrm{Eu}^{*}, \mathrm{La} / \mathrm{Sm}$ and $\mathrm{Ba} / \mathrm{Ba}^{*}$ compared to $\mathrm{b} 4 \mathrm{~B}$ and lower $\mathrm{Eu} / \mathrm{Eu} *, \mathrm{Ba} / \mathrm{Ba}^{*}$ and higher La/Sm than MS-13-SWB. 

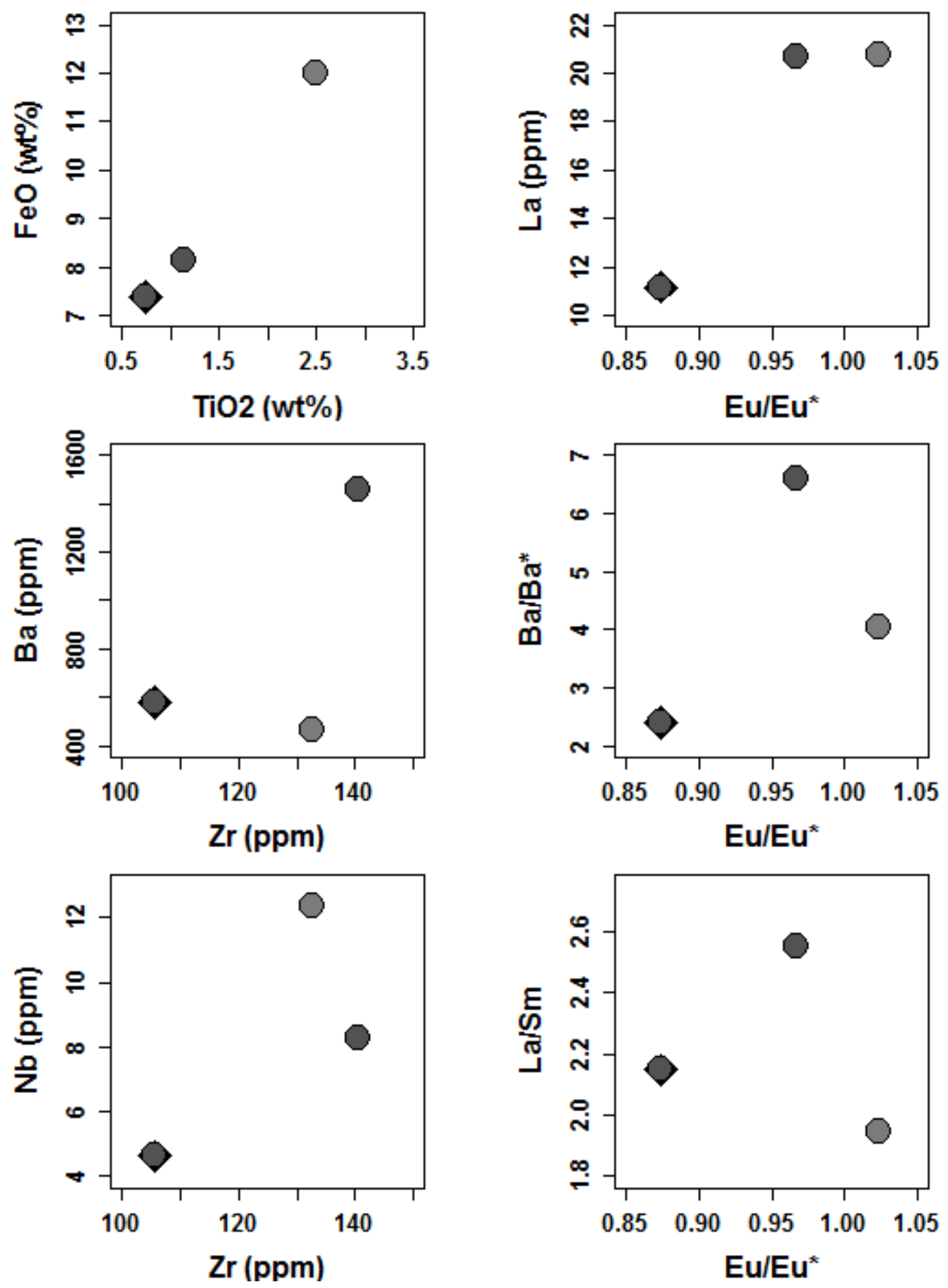

Figure 60: Bivariate plots for units b3A (black diamond), b4A and b4B (dark gray circle) and MS-13-SWB (light gray circle). Unit b4A plots on top of unit b3A, only the edges of the black diamond are visible. 
Comparison of units b3A, b4A, b4B and MS-13-SWB with multi-element diagram (Figure 61) show that b3A and b4A is less enriched in both LIL and HFS elements compared to b4B. MS-13-SWB is generally less depleted in high field strength (HFS) elements and less enriched in large ion lithophile (LIL) elements compared to both $\mathrm{b} 4 \mathrm{~A}$ and $\mathrm{b} 4 \mathrm{~B}$ resulting in an overall smoother pattern. Units b3B and b4A have similar enrichment trends.

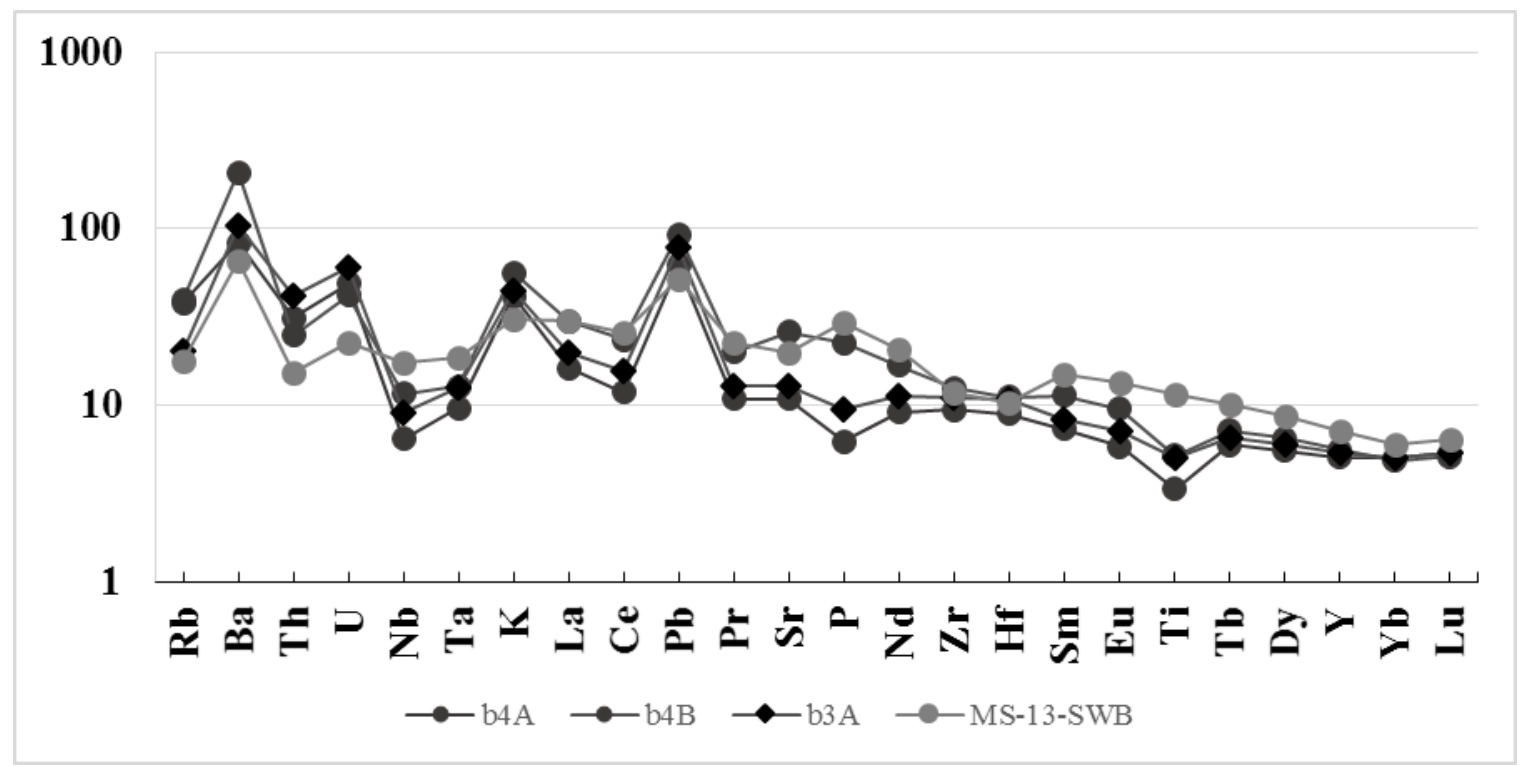

Figure 61: Multi-element diagram of units b3A, b4A, b4B and MS-13-SWB. b3A: black diamond, b4A and b4B: medium gray circles, MS-12-SWB: light gray circle. Concentrations normalized to mantle values of Sun and McDonough (1989) 


\section{Defining stratigraphic units with trace element trends}

Correlation of stratigraphic units across the study area are based on the results of field, petrographic and geochemical analysis. Trace element trends of 9 rhyolitic eruptive units, including the unit previously identified as the Buchanan ash-flow tuff (Brown and McLean, 1980), and 3 basalt/basaltic andesite units are described and presented in stratigraphic order from earliest to most recent. Additionally, Table 10 provides analyzed ranges for select major and trace element and ratio values.

Table 10: Geochemical ranges for $\mathrm{TiO}_{2}, \mathrm{FeO}^{*}$ (wt $\%$ ), select trace elements (ppm) and ratios for eruptive units at Buchanan rhyolite complex. Units R1-R8 are rhyolitic units local to Buchanan rhyolite complex, unit RT was previously identified as the Buchanan ash-flow tuff (Brown and McLean, 1980) and units Ba1, $\mathrm{Ba} 2$ and $\mathrm{BaU}$ are mafic units.

\begin{tabular}{ccccccccc}
\hline \hline Unit & $\mathrm{TiO}_{2}$ & $\mathrm{FeO}^{*}$ & $\mathrm{Ba}$ & $\mathrm{Nb}$ & $\mathrm{La}$ & $\mathrm{Zr}$ & $\mathrm{Eu} / \mathrm{Eu} *$ & $\mathrm{Ba} / \mathrm{Ba}$ \\
\hline $\mathrm{R} 1(\mathrm{n}=3)$ & $0.08-0.09$ & $0.67-1.02$ & $98-153$ & $9-13$ & $18-32$ & $210-282$ & $0.18-0.20$ & $0.08-0.11$ \\
$\mathrm{R} 2(\mathrm{n}=4)$ & $0.11-0.15$ & $0.91-1.04$ & $1051-1138$ & $7-11$ & $20-29$ & $111-127$ & $0.36-0.54$ & $0.95-1.42$ \\
$\mathrm{R} 3(\mathrm{n}=3)$ & $0.47-0.65$ & $3.51-4.17$ & $1107-1763$ & $9-11$ & $23-26$ & $211-253$ & $0.70-0.89$ & $1.70-2.84$ \\
$\mathrm{R} 4(\mathrm{n}=3)$ & $0.23-0.30$ & $1.17-2.57$ & $1373-1509$ & $11-13$ & $21-29$ & $272-311$ & $0.53-0.75$ & $1.17-1.36$ \\
$\mathrm{R} 5(\mathrm{n}=6)$ & $0.19-0.49$ & $0.82-3.45$ & $1265-1507$ & $7-11$ & $23-27$ & $147-284$ & $0.57-0.70$ & $1.31-2.15$ \\
$\mathrm{R} 6(\mathrm{n}=8)$ & $0.10-0.23$ & $0.69-1.52$ & $627-1603$ & $8-11$ & $27-36$ & $192-241$ & $0.45-0.62$ & $0.75-1.81$ \\
$\mathrm{R} 7(\mathrm{n}=2)$ & $0.13-0.25$ & $0.61-1.11$ & $1011-1709$ & $6-10$ & 18 & $168-244$ & $0.60-0.70$ & $1.89-3.18$ \\
$\mathrm{R} 8(\mathrm{n}=6)$ & $0.19-0.33$ & $1.00-2.08$ & $1406-1612$ & $8-10$ & $21-26$ & $145-166$ & $0.47-0.59$ & $1.38-1.69$ \\
$\mathrm{RT}(\mathrm{n}=3)$ & $0.23-0.98$ & $2.79-4.64$ & $1315-1572$ & $19-22$ & $36-54$ & $311-371$ & $0.61-0.81$ & $2.02-2.56$ \\
& & & & & & & & \\
$\mathrm{Ba} 1(\mathrm{n}=2)$ & $0.73-1.09$ & $7.40-8.36$ & $582-733$ & $5-7$ & $11-13$ & $105-123$ & $0.87-0.94$ & $2.40-3.58$ \\
$\mathrm{Ba} 2(\mathrm{n}=1)$ & 1.13 & 8.13 & 1456 & 8 & 21 & 141 & 0.97 & 4.03 \\
$\mathrm{BaU}(\mathrm{n}=1)$ & 2.5 & 11.99 & 465 & 12 & 21 & 133 & 1.02 & 3.58 \\
\hline
\end{tabular}




\section{Rhyolite unit R1}

Porphyritic rhyolite recognized in the northwest of the study area as unit 1A.

Quartz and alkali feldspar phenocrysts are easily visible with the unaided eye and are distinct to this unit. Ar-Ar age dating obtained by Hess (2014) determined rhyolite unit $\mathrm{R} 1$ is $16.13 \pm 0.11 \mathrm{Ma}$.

Distinct geochemical signatures include major element oxide wt $\%$ of $\mathrm{FeO} *<1$, $\mathrm{TiO} 2<0.1$ and $\mathrm{MgO} \sim 0$. Trace element concentrations of $\mathrm{Ba} 98-153 \mathrm{ppm}$ and trace element ratio values of $\mathrm{Eu} / \mathrm{Eu}^{*}<0.2$ and $\mathrm{Ba} / \mathrm{Ba}^{*}<0.1$. Multi-element diagram, Figure 62, displays the average enrichment and depletion trends for this unit.

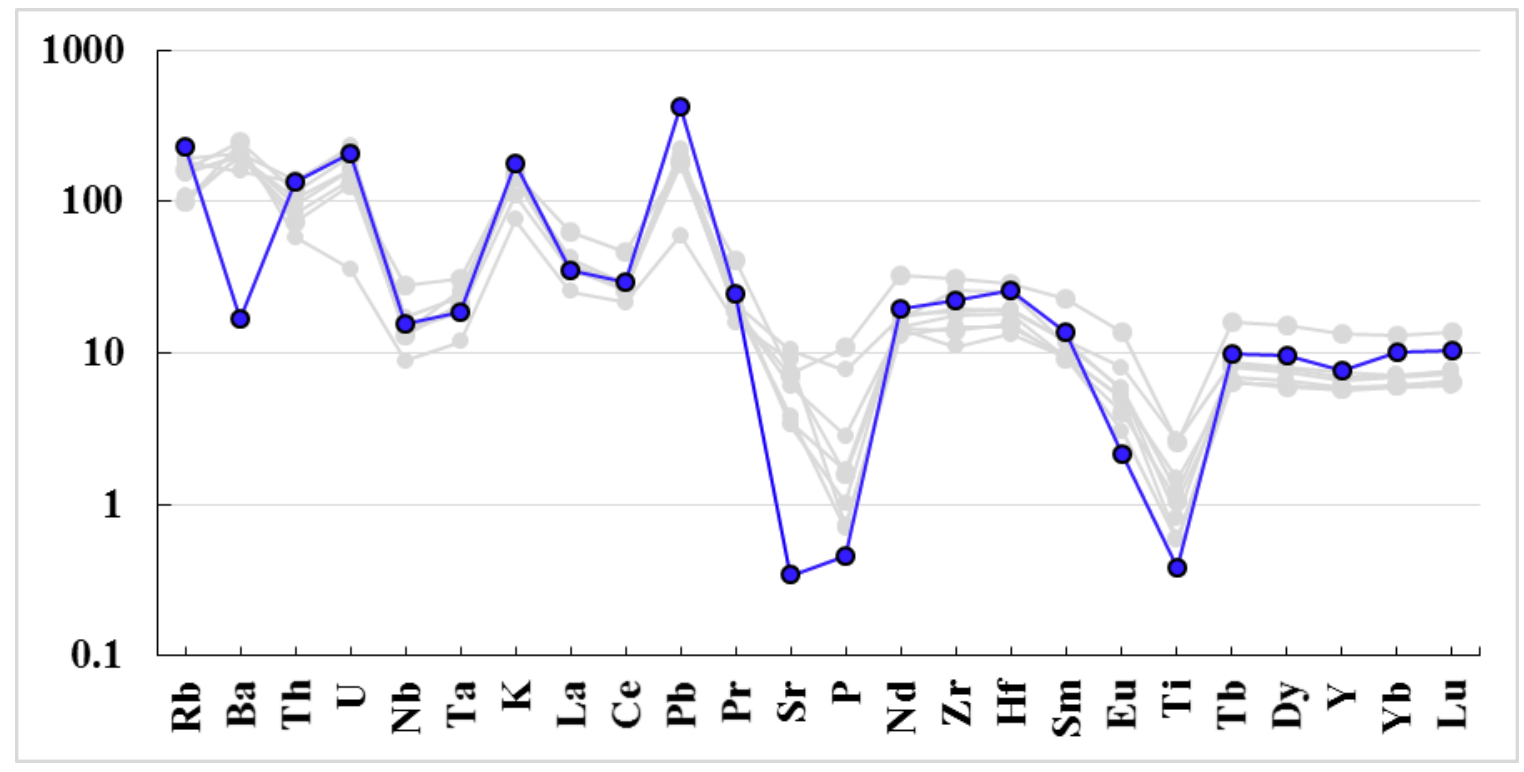

Figure 62: Multi-element diagram of Rhyolite unit R1 (dark blue) in comparison to average of other rhyolite groups (grayed). Concentrations normalized to mantle values of Sun and McDonough (1989). 


\section{Basaltic Andesite unit Ba1}

Porphyritic basaltic andesite recognized in the center of the study area as b3B and south as b4A. Plagioclase feldspar phenocrysts are easily visible with the unaided eye.

Distinct geochemical signatures include major element oxide wt $\%$ of $\mathrm{TiO} 2<\sim 1$ and $\mathrm{P} 2 \mathrm{O} 5<\sim 0.2$. Trace element concentrations of $\mathrm{Ba} 582-733 \mathrm{ppm}, \mathrm{Nb} 4.62-6.54$ and $\mathrm{Ba} / \mathrm{Ba}^{*}$ trace element ratio value 2.4-3.6. Multi-element diagram, Figure 63, displays the average enrichment and depletion trends for this unit.

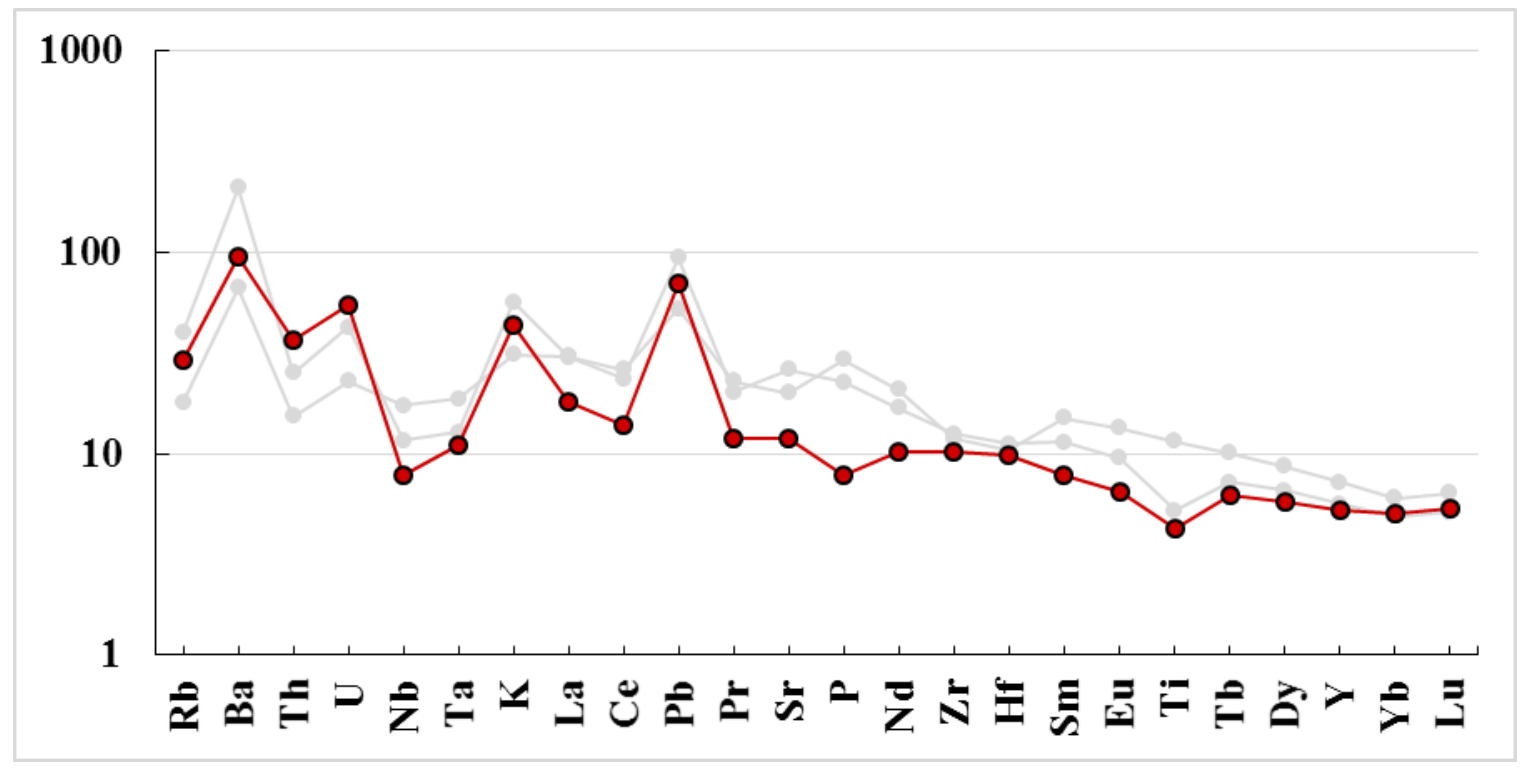

Figure 63: Multi-element diagram of basaltic andesite unit Ba1 in comparison to other basalt groups (grayed). Concentrations normalized to mantle values of Sun and McDonough (1989). 


\section{Rhyolite unit R2}

Aphyric rhyolite recognized in the center and south of the study area as units $3 \mathrm{~A}$

and 4B. All occurrences are either obsidian nodules in vesiculated vitric matrix or vesiculated vitric bedrock slopes.

Distinct geochemical signatures include major element oxide wt $\%$ of $\mathrm{FeO} *<\sim 1$ and $\mathrm{TiO} 2<0.15$. Trace element concentrations of $\mathrm{Ba} 1051-1138$ ppm, $\mathrm{Zr} 111-127$ ppm and trace element ratio values of $\mathrm{Eu} / \mathrm{Eu}^{*}<.4$ and $\mathrm{La} / \mathrm{Sm}>3.86$. Multi-element diagram, Figure 64, displays the average enrichment and depletion trends for this unit.

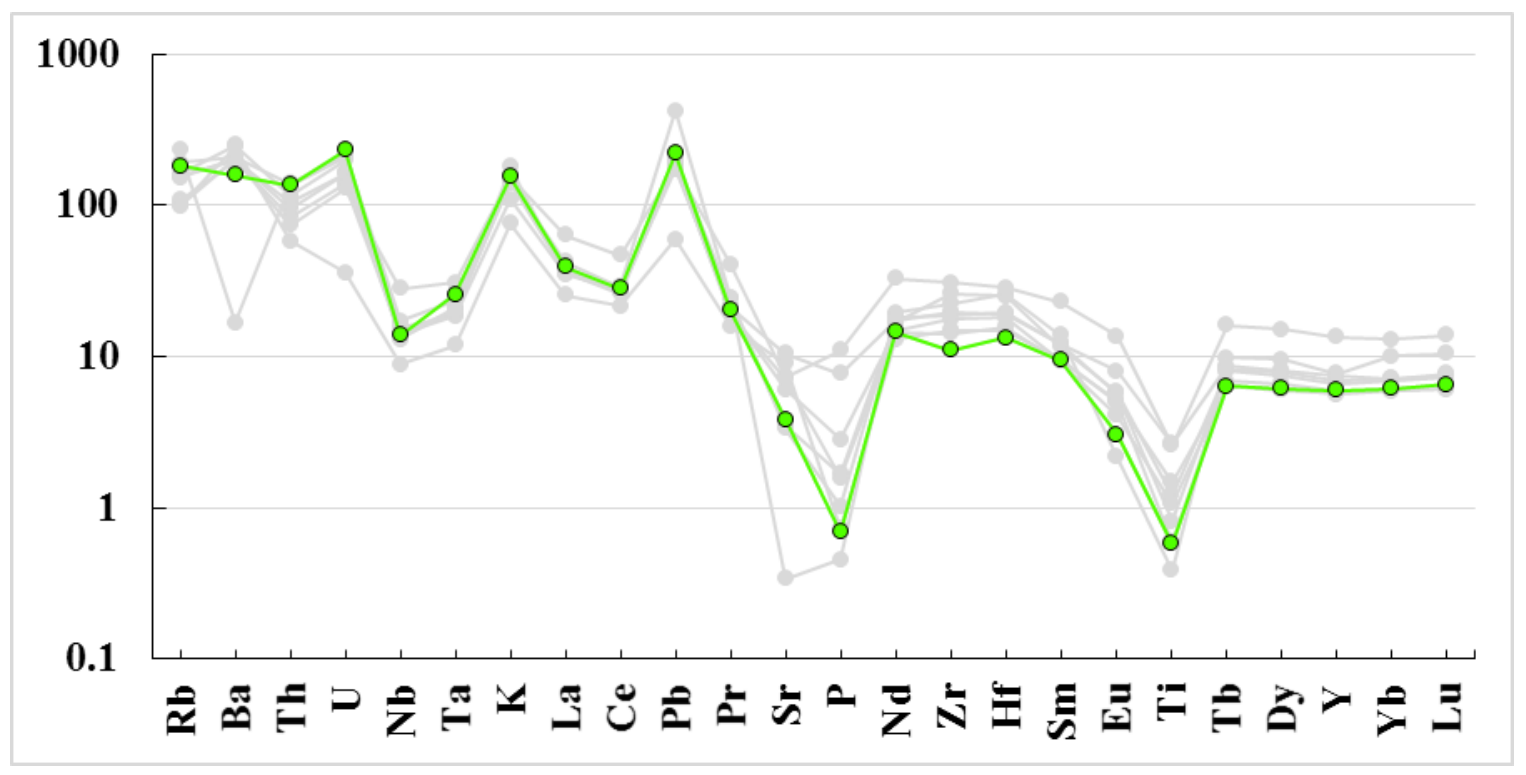

Figure 64: Multi-element diagram of Rhyolite unit R2 (bright green) in comparison to average of other groups (grayed). Concentrations normalized to mantle values of Sun and McDonough (1989). 


\section{Basaltic Andesite unit Ba2}

Porphyritic basaltic andesite recognized in the south of the study area as b4B.

Phenocryst abundance is $\sim 15 \%$ tabular plagioclase feldspar phenocrysts that are easily visible with the unaided eye.

Distinct geochemical signatures include major element oxide wt $\%$ of $\mathrm{TiO} 2>\sim 1$ and $\mathrm{P} 2 \mathrm{O} 5 \sim 0.5$. Trace element concentrations of $\mathrm{Ba} 1456 \mathrm{ppm}, \mathrm{Nb} 8.28$ and $\mathrm{Ba} / \mathrm{Ba} *$ trace element ratio value 6.6. Multi-element diagram, Figure 65, displays the average enrichment and depletion trends for this unit.

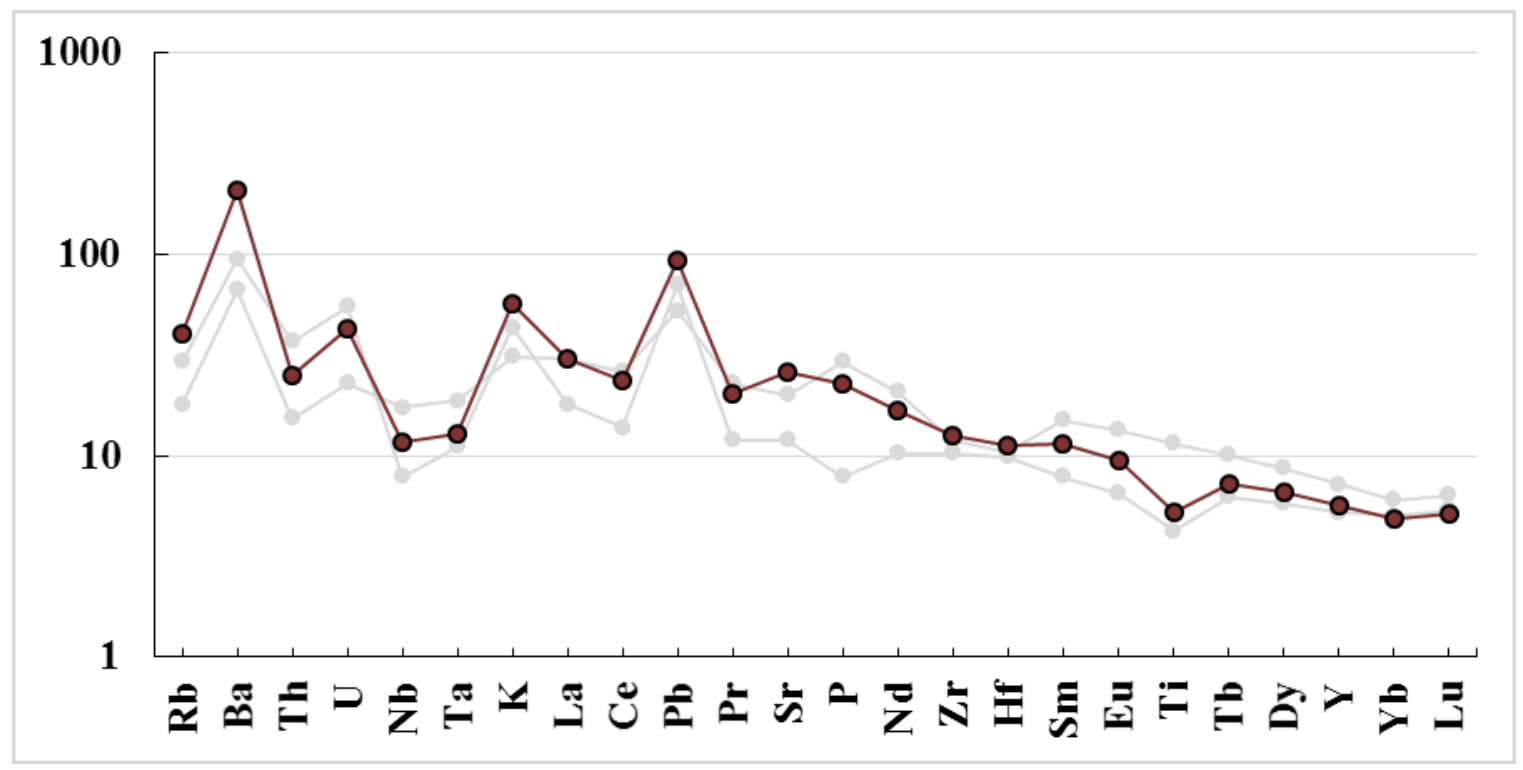

Figure 65: Multi-element diagram of basaltic andesite unit Ba2 (poppy red) in comparison to other basalt groups (grayed). Concentrations normalized to mantle values of Sun and McDonough (1989). 


\section{Rhyolite unit R3}

Porphyritic rhyolite recognized in the northwest of the study area as unit $1 \mathrm{~B}$ and south as 4C. Phenocryst abundance is $\sim 10-15 \%$ plagioclase feldspar phenocrysts that are easily visible with the unaided eye.

Distinct geochemical signatures include major element oxide wt\% of $\mathrm{FeO} * 3.5$ -

4.2 and $\mathrm{TiO} 2$ 0.47-0.65. Trace element concentrations of $\mathrm{Ba}$ are variable, 1107-

$1763 \mathrm{ppm}$, likely due to alteration, and trace element ratio values of Eu/Eu* 0.71-0.88.

Multi-element diagram, Figure 66, displays the average enrichment and depletion trends for this unit.

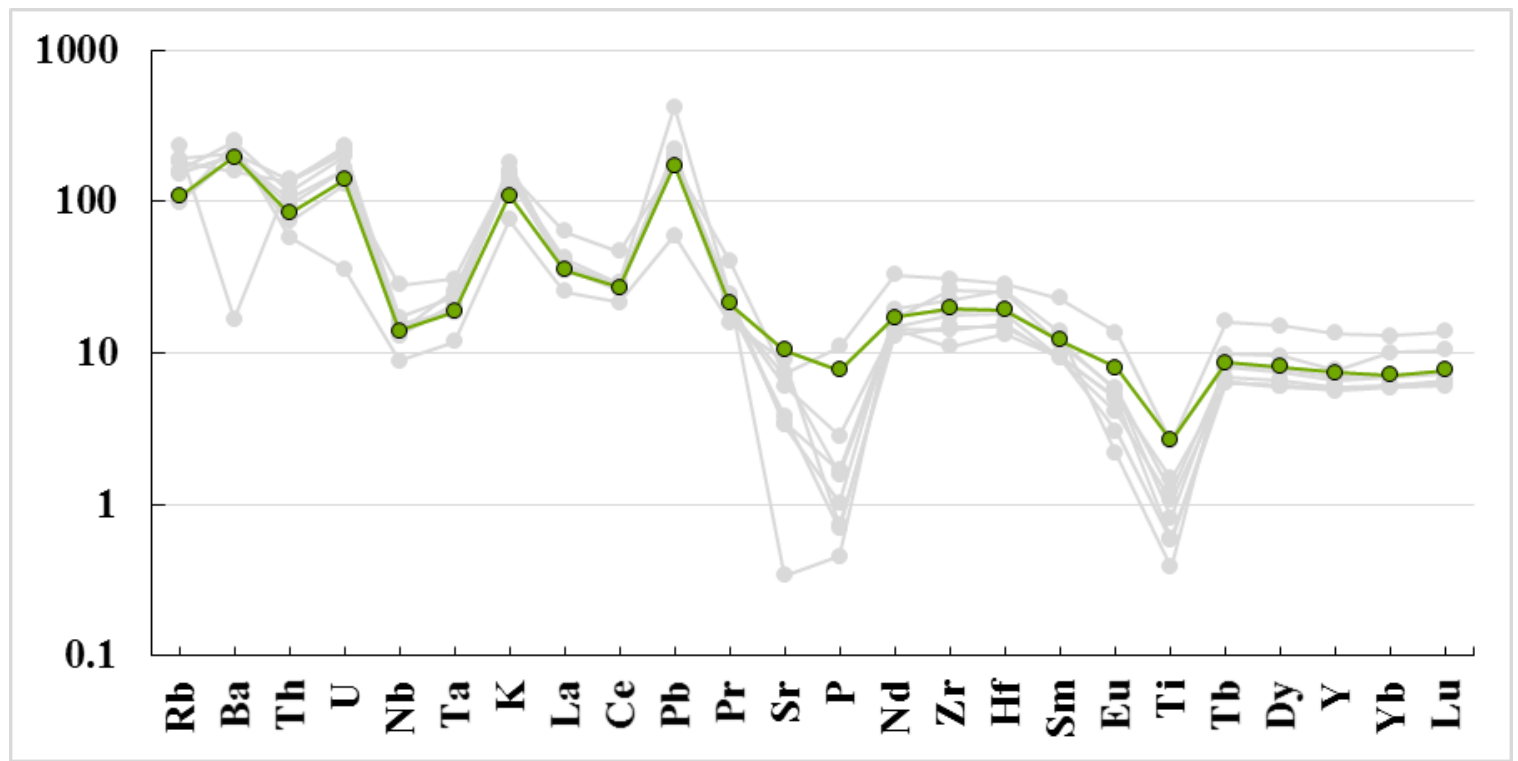

Figure 66: Multi-element diagram of Rhyolite unit R3 (green) in comparison to average of other rhyolite groups (grayed). Concentrations normalized to mantle values of Sun and McDonough (1989). 


\section{Rhyolite unit R4}

Porphyritic rhyolite recognized in the center of the study area as unit 3B.

Phenocryst abundance is $\sim 10-15 \%$ plagioclase and sanidine phenocrysts that are easily visible with the unaided eye.

Distinct geochemical signatures include major element oxide wt $\%$ of $\mathrm{FeO} * 1.2$ 2.6 and $\mathrm{TiO} 2$ 0.25-0.3. Trace element concentrations of $\mathrm{Ba} 1373-1509$ ppm, $\mathrm{Zr} 272-311$ ppm and trace element ratio values of $\mathrm{Eu} / \mathrm{Eu}^{*}>0.5$ and $\mathrm{La} / \mathrm{Sm}$ 3.0-3.4. Multi-element diagram, Figure 67, displays the average enrichment and depletion trends for this unit.

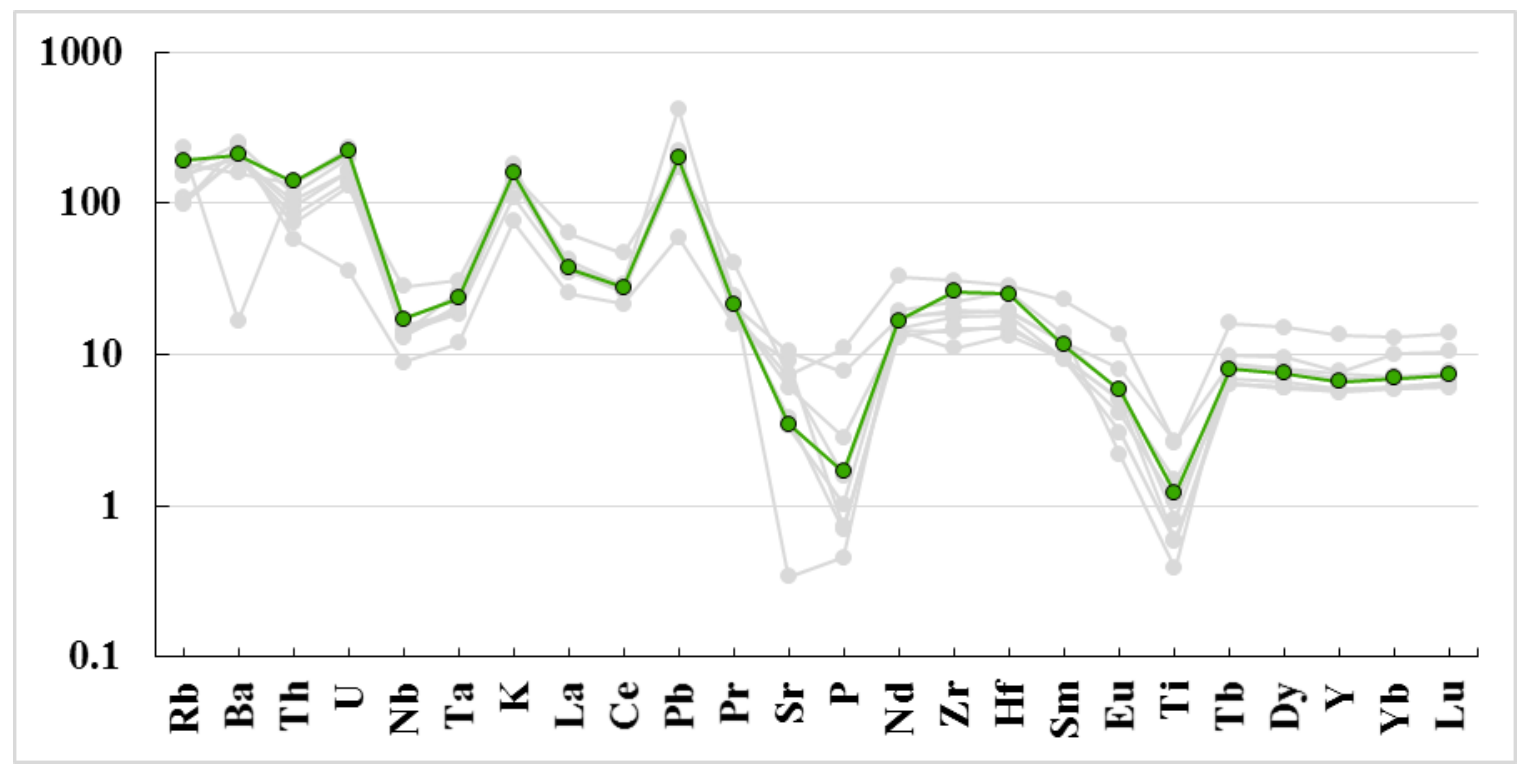

Figure 67: Multi-element diagram of Rhyolite unit R4 (medium green) in comparison to average of other rhyolite groups (grayed). Concentrations normalized to mantle values of Sun and McDonough (1989). 


\section{Rhyolite unit R5}

Porphyritc rhyolite recognized in the center of the study area as unit $3 \mathrm{C}$ and northeast as $5 \mathrm{~B}$. Phenocryst abundance is $\sim 1 \%$.

Distinct geochemical signatures include major element oxide wt $\%$ of $\mathrm{TiO} 20.2$ 0.5 and variable $\mathrm{FeO}^{*}$ between $0.8-3.45$. Trace element concentrations of $\mathrm{Ba} 1265-1507$ ppm, $\mathrm{Zr} 147-284 \mathrm{ppm}$ and trace element ratio values of $\mathrm{Eu} / \mathrm{Eu}^{*} 0.57-0.70$ and $\mathrm{La} / \mathrm{Sm} 3.6-$ 4.0. Multi-element diagram, Figure 68, displays the average enrichment and depletion trends for this unit.

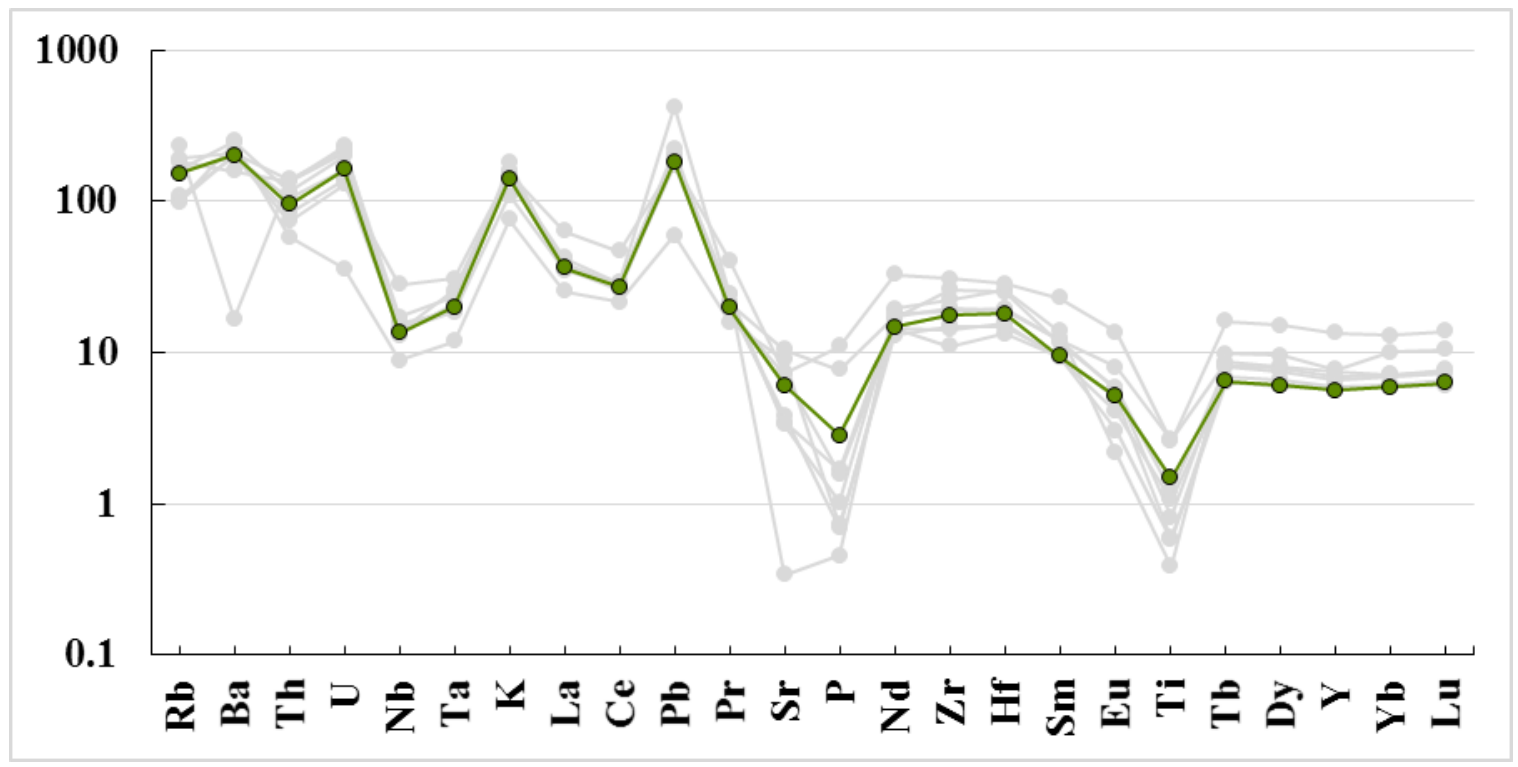

Figure 68: Multi-element diagram of Rhyolite unit R5 (olive green) in comparison to average of other rhyolite groups (grayed). Concentrations normalized to mantle values of Sun and McDonough (1989). 


\section{Rhyolite unit R6}

Porphyritic rhyolite recognized in the west as unit $2 \mathrm{~A}$, the center as unit $3 \mathrm{D}$, and the southeast as unit 4A. Phenocryst abundance is variable between $\sim 1-5 \%$.

Distinct geochemical signatures include major element oxide wt $\%$ of $\mathrm{FeO} * 0.69$ 1.52 and $\mathrm{TiO} 2$ 0.18-0.23. Trace element concentrations of Ba 1434-1603 ppm, Zr 192$241 \mathrm{ppm}$ and trace element ratio values of $\mathrm{Eu} / \mathrm{Eu}^{*}$ 0.45-0.68 and $\mathrm{La} / \mathrm{Sm}$ 2.73-4.20. Multielement diagram, Figure 69, displays the average enrichment and depletion trends for this unit.

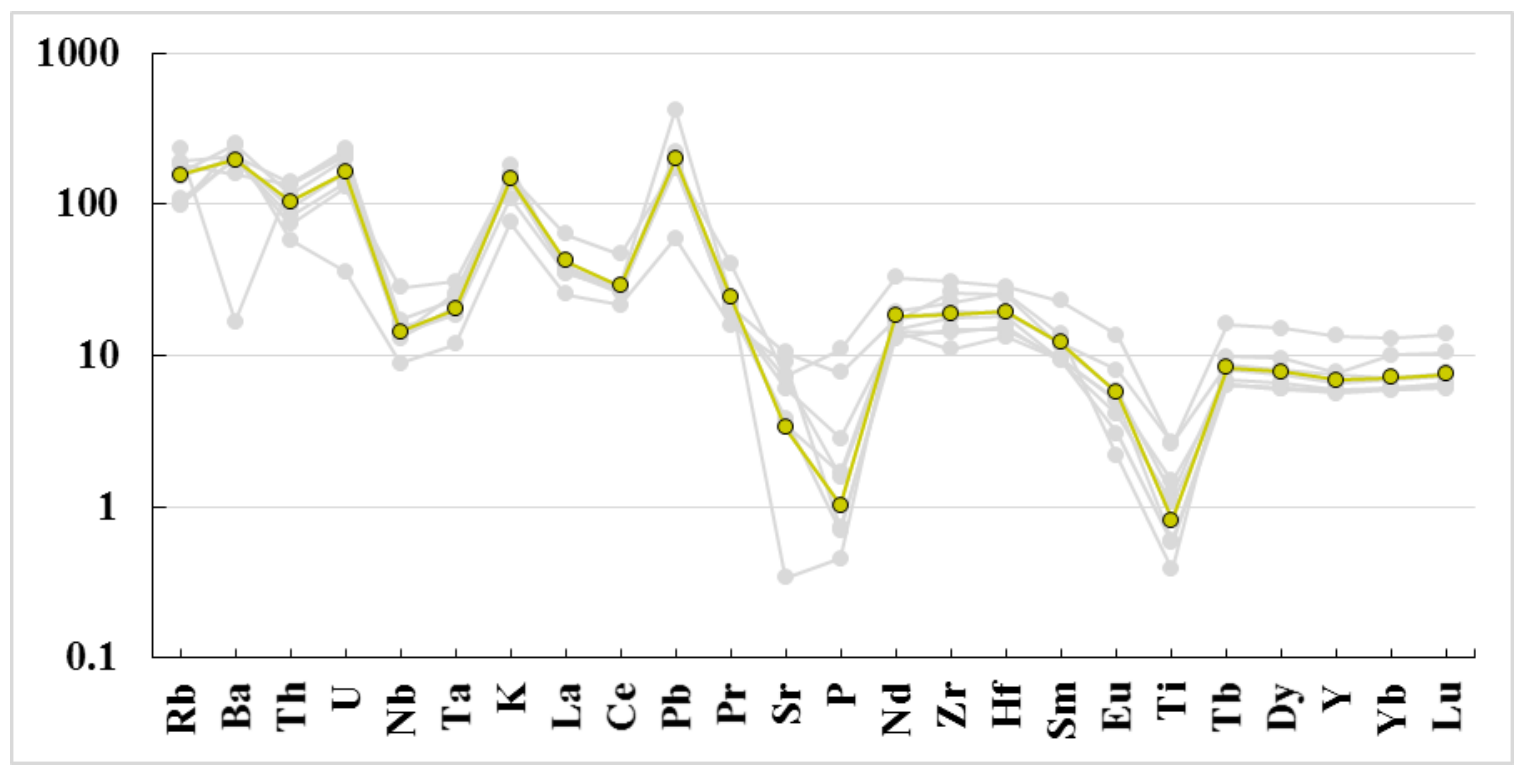

Figure 69: Multi-element diagram of Rhyolite unit R6 (yellow) in comparison to average of other rhyolite groups (grayed). Concentrations normalized to mantle values of Sun and McDonough (1989). 


\section{Rhyolite pyroclastic unit R7}

Welded lithic tuff and lapilli ash-fall tuff recognized in the west as unit 2B.

Distinct geochemical signatures include major element oxide wt $\%$ of $\mathrm{FeO} * 0.61$ -

1.11 and TiO2 0.13-0.25. Trace element concentrations of Ba 1011-1709 ppm, Zr 168$244 \mathrm{ppm}$ and trace element ratio values of Eu/Eu* $0.60-0.70$ and $\mathrm{La} / \mathrm{Sm} 2.65-2.75$. Multielement diagram, Figure 70, displays the average enrichment and depletion trends for this unit.

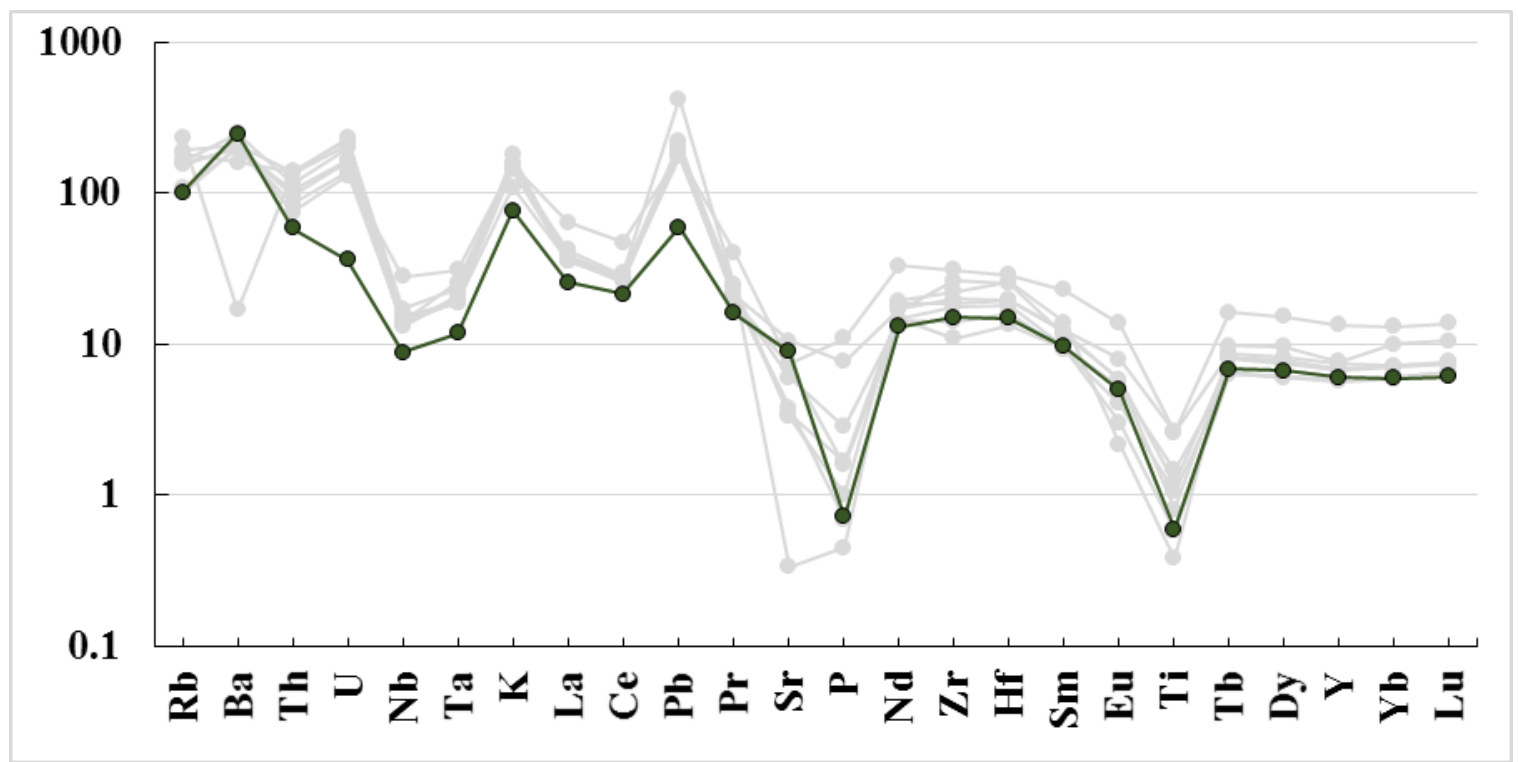

Figure 70: Multi-element diagram of Rhyolite unit R7 (dark green) in comparison to average of other rhyolite groups (grayed). Concentrations normalized to mantle values of Sun and McDonough (1989). 


\section{Rhyolite unit R8}

Porphyritic rhyolite recognized in the center of the study area as unit $3 \mathrm{E}$ and northwest as unit 5A. Phenocryst abundance is variable between $\sim 0-5 \%$.

Distinct geochemical signatures include major element oxide wt\% of $\mathrm{FeO} * 1.00$ 2.08 and $\mathrm{TiO}_{2}$ 0.19-0.33. Trace element concentrations of $\mathrm{Ba} 1406-1612 \mathrm{ppm}, \mathrm{Zr} 145-$ $166 \mathrm{ppm}$ and trace element ratio values of $\mathrm{Eu} / \mathrm{Eu}^{*} 0.48-0.50$ and $\mathrm{La} / \mathrm{Sm} 3.98-4.22$. Multielement diagram, Figure 71, displays the average enrichment and depletion trends for this unit.

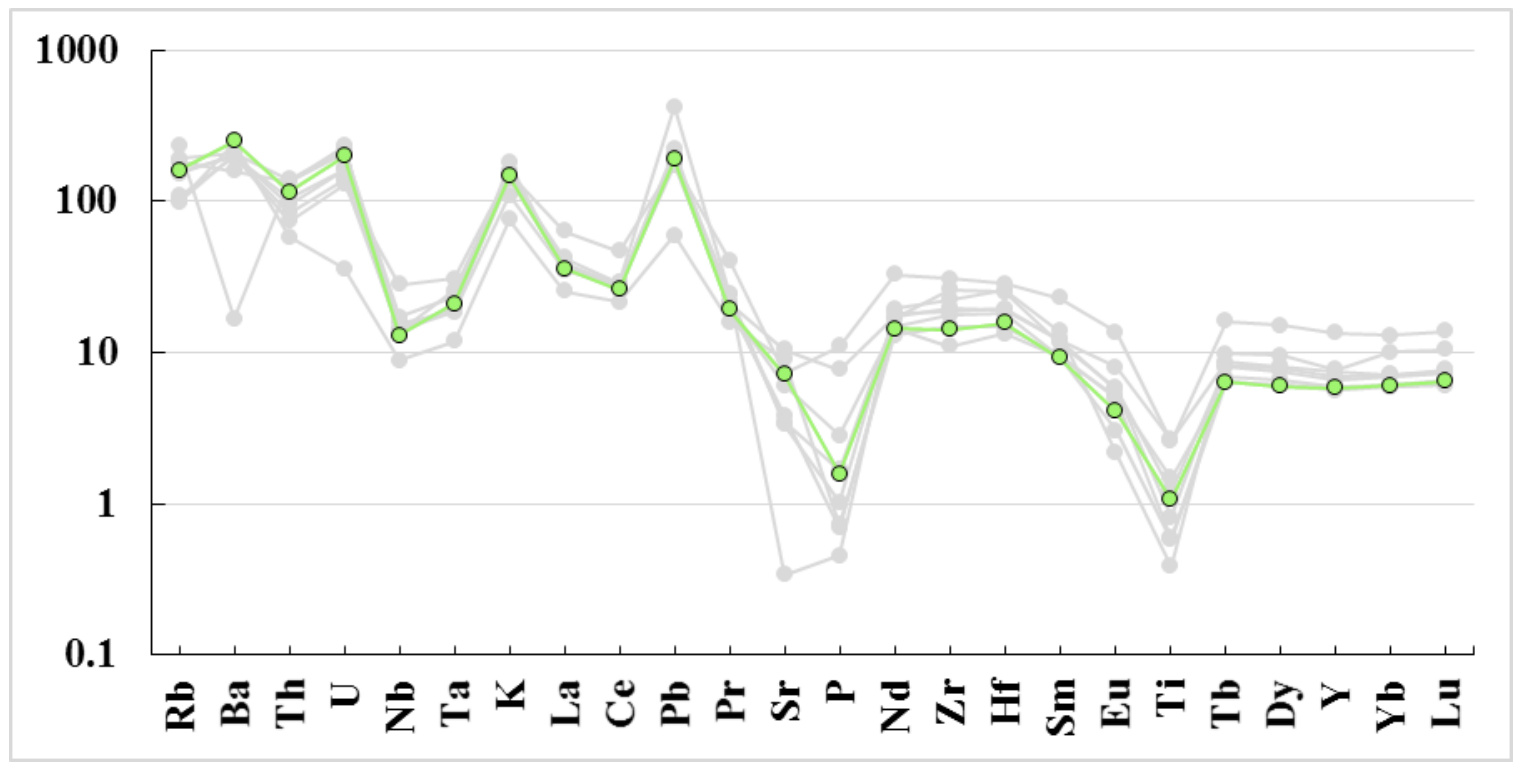

Figure 71: Multi-element diagram of Rhyolite unit R8 (pale green) in comparison to average of other rhyolite groups (grayed). Concentrations normalized to mantle values of Sun and McDonough (1989). 


\section{Rhyolitic Tuff unit RT}

Porphyritic pumiceous tuff recognized throughout the study area but most

prominently in the north as unit 3F. Phenocryst abundance is $1-5 \%$ plagioclase feldspar.

Undeformed pumice comprises $20 \%$ of incipiently welded tuff volume.

Distinct geochemical signatures include major element oxide wt\% of $\mathrm{FeO} * 2.79$ -

4.64 and $\mathrm{TiO}_{2}$ 0.23-0.98. Trace element concentrations of $\mathrm{Ba} 1315-1572 \mathrm{ppm}, \mathrm{Zr} 311$ -

$371 \mathrm{ppm}, \mathrm{Nb} 18.98-22.22$ and trace element ratio values of $\mathrm{Eu} / \mathrm{Eu}^{*} 0.61-0.81$ and $\mathrm{La} / \mathrm{Sm}$

2.48-3.23. Multi-element diagram, Figure 72, displays the average enrichment and depletion trends for this unit.

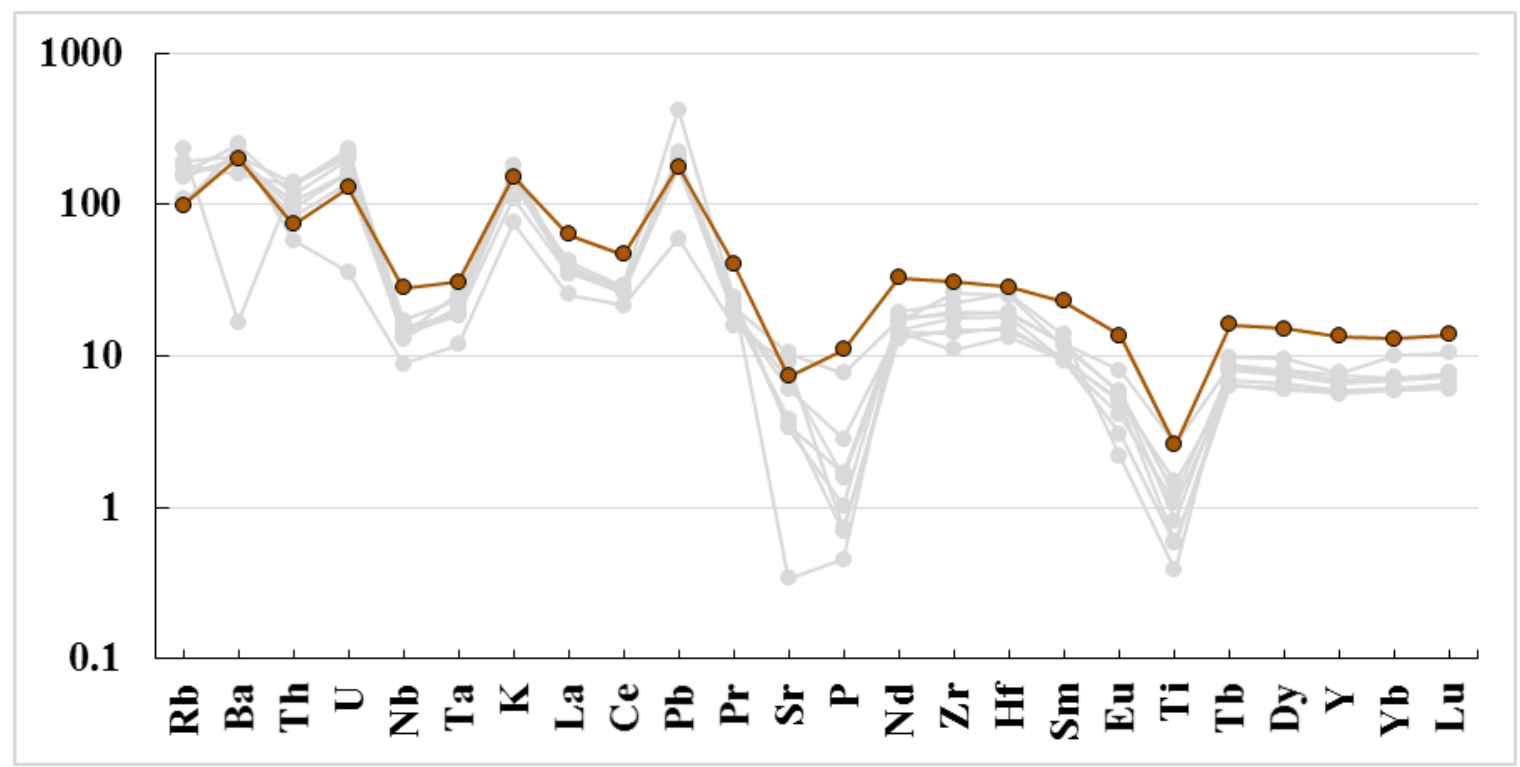

Figure 72: Multi-element diagram of Rhyolite unit RT (tawny orange) in comparison to average of other rhyolite groups (grayed). Concentrations normalized to mantle values of Sun and McDonough (1989). 


\section{Undifferentiated Basalt BaU}

Undifferentiated basalt flows exposed throughout the study area are the youngest units.

Distinct geochemical signatures of one unit analyzed (sample MS-13-SWB) include major element oxide wt\% of $\mathrm{FeO}^{*} 12, \mathrm{TiO} 22.5$ and $\mathrm{P} 2 \mathrm{O} 5$ 0.64. Trace element concentrations of $\mathrm{Ba} 465 \mathrm{ppm}, \mathrm{Nb} 12.36$ and trace element ratio values of $\mathrm{Eu} / \mathrm{Eu}^{*} 1.03$ and $\mathrm{Ba} / \mathrm{Ba}^{*}$ 4.0. Multi-element diagram, Figure 73, displays the average enrichment and depletion trends for this unit. Additionally, sample MS-12-SWB has an Ar-Ar age date of $13.79 \pm 0.09 \mathrm{Ma}$.

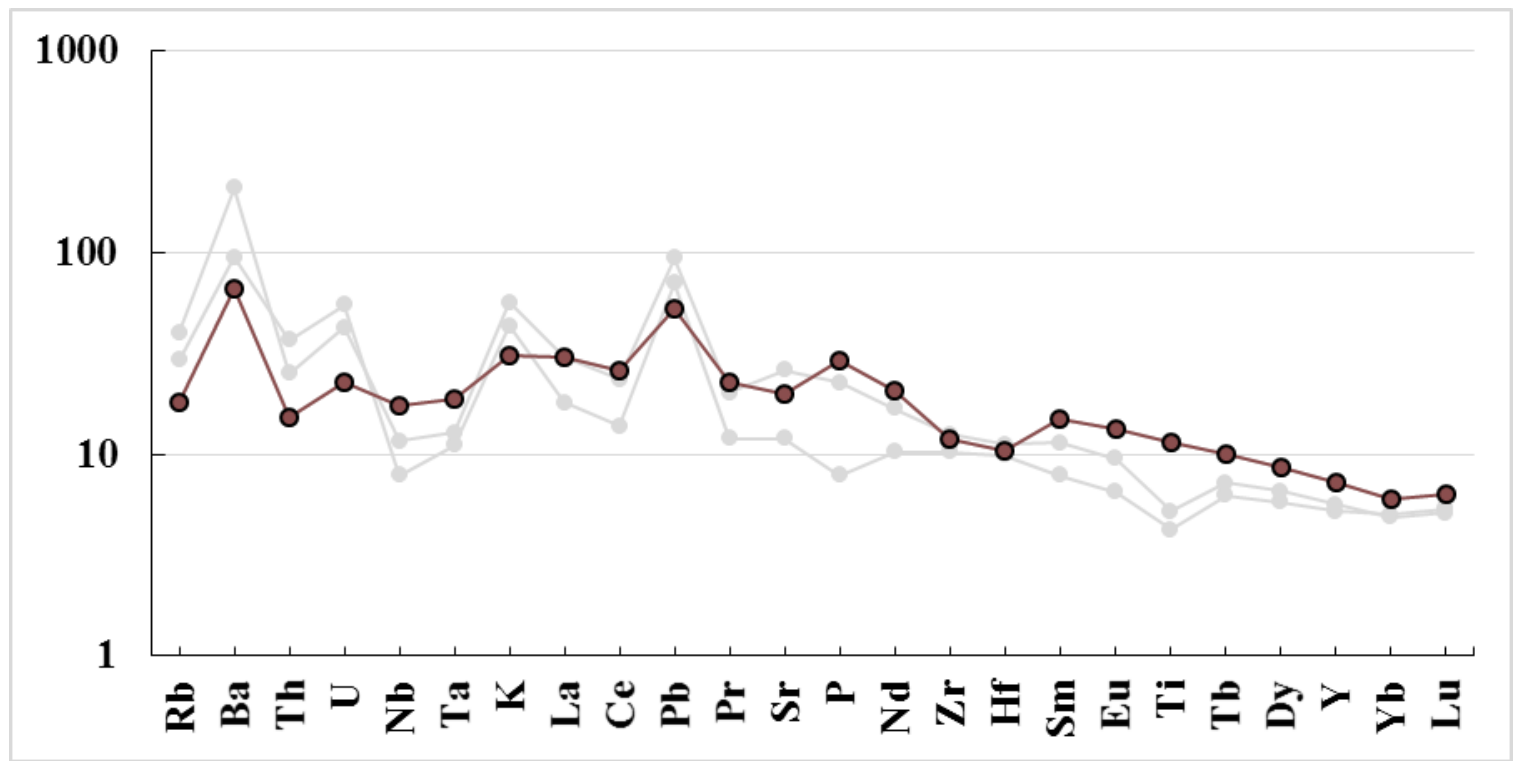

Figure 73: Multi-element diagram of basaltic andesite unit BaU (dark red) in comparison to other basalt groups (grayed). Concentrations normalized to mantle values of Sun and McDonough (1989). 


\section{Discussion and Conclusions}

\section{Trace element trends of rhyolite units}

The rhyolites at the Buchanan volcanic complex have subtle differences in trace

element abundances. The differences are most notable in $\mathrm{Ba}, \mathrm{Sr}, \mathrm{P}, \mathrm{Ti}$ and Nd-Zr-Hf.

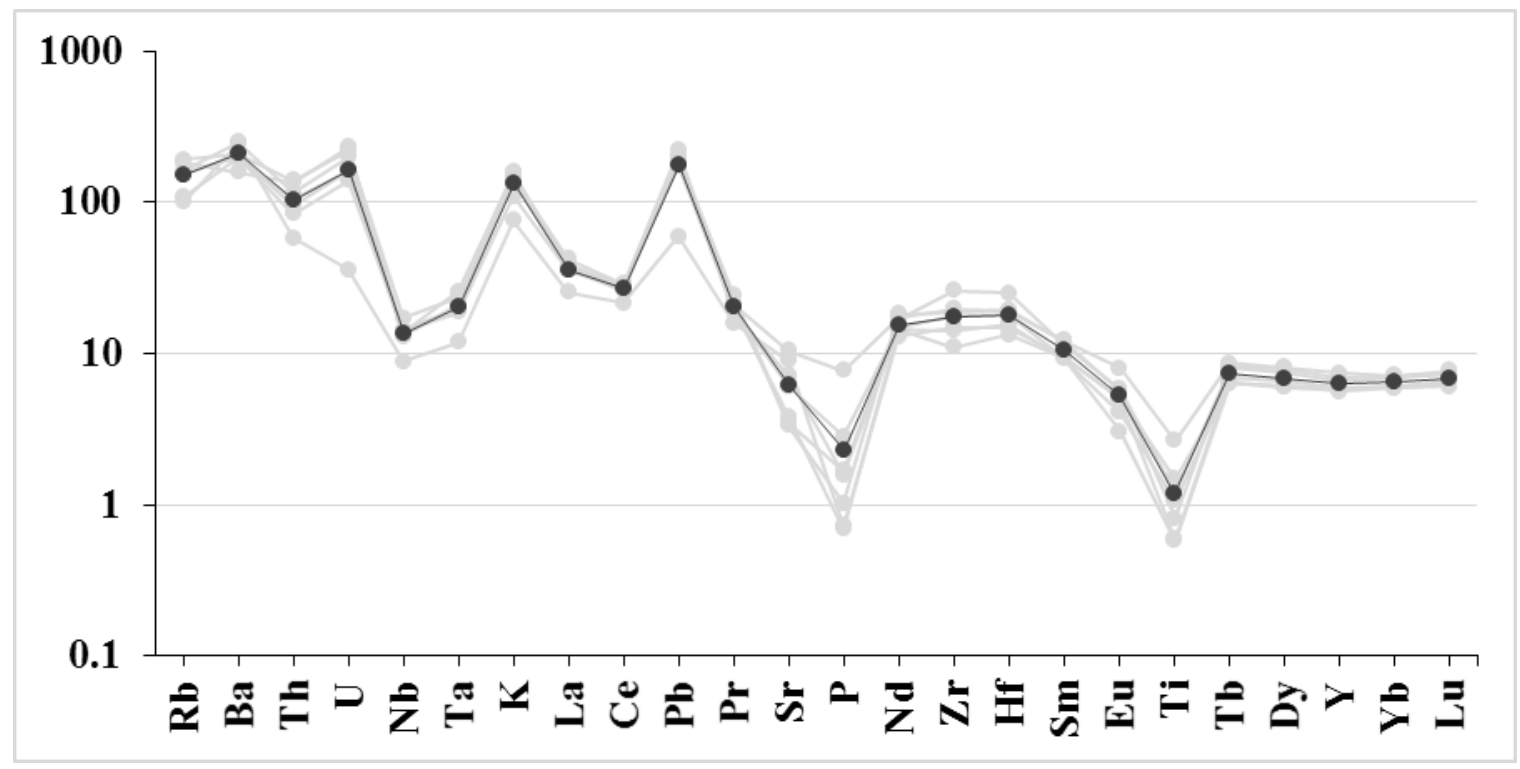

Figure 74: Multi-element diagram of average Buchanan rhyolite complex rhyolite (dark gray), calculated from groups R2-R8, in comparison to groups R2-R8 (grayed). Concentrations normalized to mantle values of Sun and McDonough (1989).

With the exception of unit R1, the rhyolite units are variably enriched in Ba with values of $\mathrm{Ba} / \mathrm{Ba}^{*}$ ranging from 1.0 to 3.2 . $\mathrm{Sr}$ is variably depleted, when compared to $\mathrm{Pr}$ and $\mathrm{Nd}$, with $\mathrm{Sr} / \mathrm{Sr}^{*}$ values ranging from 0.18 to 0.62 (Figure 75 ). 


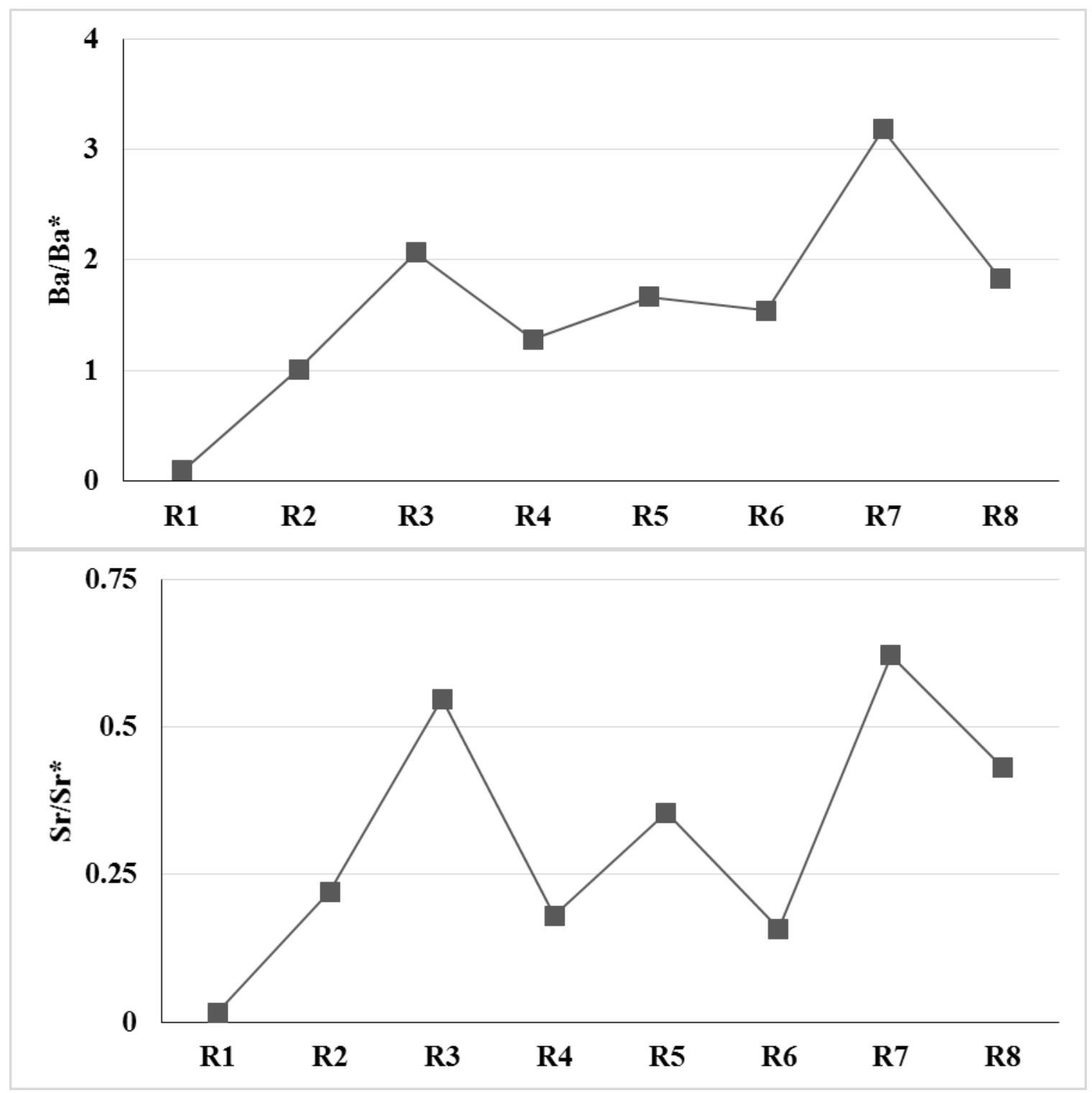

Figure 75: Values of $\mathrm{Ba} / \mathrm{Ba}^{*}$ and $\mathrm{Sr} / \mathrm{Sr} *$ for units R1-R8.

$\mathrm{P}$ and $\mathrm{Ti}$ are depleted in all rhyolites, which could result from crystal fractionation of apatite and Ti-Fe oxide minerals, respectively. Differences in $\mathrm{Nd}-\mathrm{Zr}$-Hf are also seen in the rhyolites. The apparent depletion of $\mathrm{Zr}$ could result from crystal fractionation of zircon or relative enrichment of $\mathrm{Nd}$ and $\mathrm{Hf}$; conversely, enrichment of $\mathrm{Zr}$ could result from the presence of zircon inclusions in phenocrysts. The latter possibility seems more 
likely with these rhyolites as greater enrichment in $\mathrm{Zr}$ tends to correlate with greater phenocryst abundance and observed inclusions. Additionally, Streck and Grunder (1997) show that although $\mathrm{Zr}$ and $\mathrm{Hf}$ behave geochemically similar, changes in $\mathrm{Zr} / \mathrm{Hf}$ can occur during fractionation of zircon.

\section{Trace element trends of basalt units}

The stratigraphy of Buchanan rhyolite complex divides the three basaltic andesite units between pre/coeval-rhyolite-emplacement (units Ba1 and Ba2) and post-rhyoliteemplacement (unit BaU). Multiple post-rhyolite basalts are found within the study area, but were not differentiated and analyzed beyond one sample, MS-13-SWB from Streck that has an age of $13.79 \pm 0.09$ (unpublished data; Wright et al., 2016). Similarities among all samples include enrichment in $\mathrm{Ba}$ and $\mathrm{Pb}$ and depletion in $\mathrm{Nb}$ - $\mathrm{Ta}$; however, the depletion of $\mathrm{Nb}$ - $\mathrm{Ta}$ and enrichment in $\mathrm{Pb}$ are much greater in $\mathrm{Ba} 1$ and $\mathrm{Ba} 2$ (Figure 76).

Units $\mathrm{Ba} 1$ and $\mathrm{Ba} 2$ have similar enrichment trends in $\mathrm{Rb}-\mathrm{Pr}$ with $\mathrm{Ba} 2$ being slightly more enriched except in Th and $\mathrm{U}$. These units also show similar depletion of $\mathrm{Ti}$ which is not seen in unit $\mathrm{BaU}$. Differences between $\mathrm{Ba} 1$ and $\mathrm{Ba} 2$ are seen in the elements from $\mathrm{Sr}$ to $\mathrm{Sm} . \mathrm{Ba} 2$ is enriched in $\mathrm{Sr}$ and $\mathrm{P}$ relative to $\mathrm{Pr}$ and $\mathrm{Nd}$, and slightly depleted in $\mathrm{Zr}-\mathrm{Hf}$ relative to $\mathrm{Nd}$ and $\mathrm{Sm}$. Ba1 does not have any relative $\mathrm{Sr}$ enrichment, is depleted in $\mathrm{P}$, is neither enriched or depleted in $\mathrm{Zr}-\mathrm{Hf}$ and is slightly depleted in $\mathrm{Sm}$. 
The depletion in $\mathrm{Nb}$, Ta and $\mathrm{Ti}$ in units $\mathrm{Ba} 1$ and $\mathrm{Ba} 2$ could be caused by crystal fractionation of Ti-Fe oxides. The slight depletion of $\mathrm{P}$ in Ba1 could be the result of fractionation of a small amount of apatite.

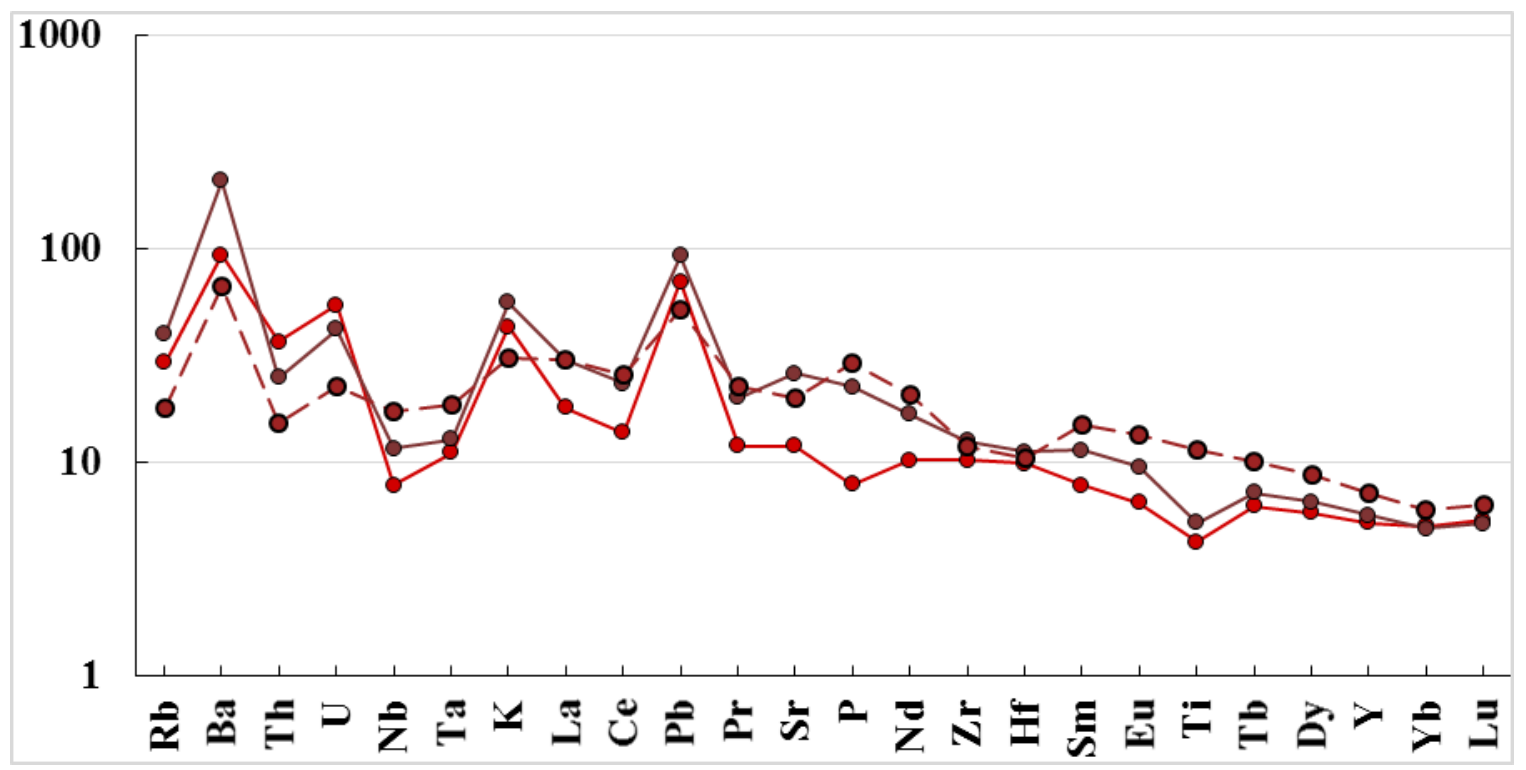

Figure 76: Multi-element diagram of mafic units Ba1 (bright red, solid line), Ba2 (dark red, solid line) and $\mathrm{BaU}$ (medium red, dashed line). Concentrations normalized to mantle values of Sun and McDonough (1989).

Definitive correlation of unit Bal with regional mafic units older than the age date of $16.13 \pm 0.11 \mathrm{Ma}$ (Hess, 2014) on rhyolite unit R1 (e.g. Steens or Grande Ronde Basalt) encounters geochemical discrepancies. Figure 77 illustrates the trace element averages for units $\mathrm{Ba} 1$ and $\mathrm{Ba} 2$ compared to the average values of Steens and Grande Ronde Basalts. Both regional basalt units contain units that share geochemical trends with the mafic units of Buchanan rhyolite complex such as Ba enrichment and depletion of $\mathrm{Nb}$-Ta and Ti. When plotting $\mathrm{K}_{2} \mathrm{O}$ vs. $\mathrm{TiO}_{2} / \mathrm{P}_{2} \mathrm{O}_{5}$ (Figure 78) after Camp et al. (2002) units $\mathrm{Ba} 1$ and $\mathrm{Ba} 2$ more closely correlate to the Birch Creek and Hunter Creek Basalt 


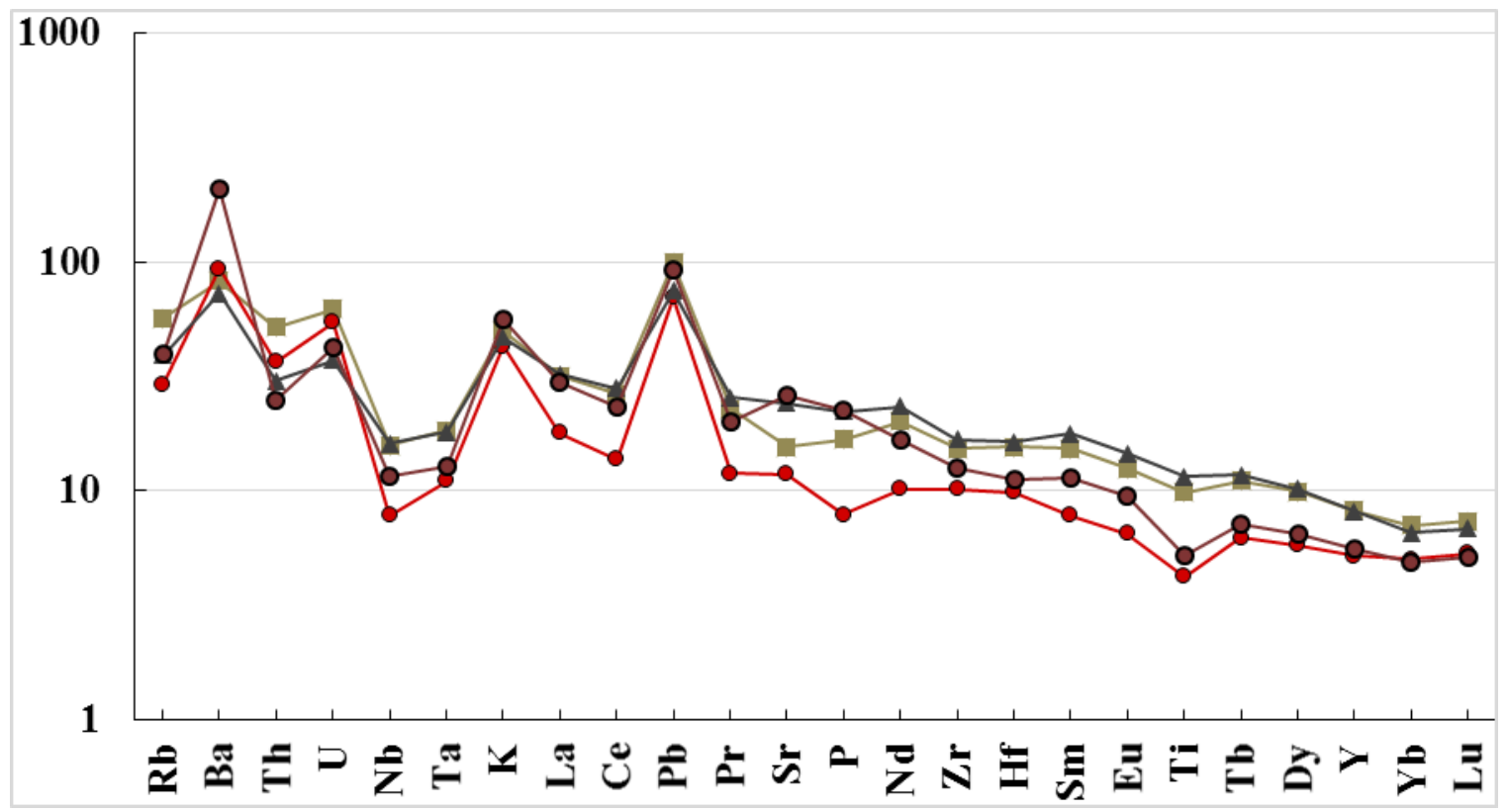

Figure 77: Multi-element diagram of mafic units Ba1 (bright red) and Ba2 compared to average values of Grande Ronde Basalt (olive green squares) and Upper Steens Basalt (dark grey squares). Grande Ronde Basalt and Steens Basalt averages data from Wolff et al. (2008). Concentrations normalized to mantle values of Sun and McDonough (1989).

than the Upper Pole Creek, which is indistinguishable from Imnaha Basalt. Camp (2002) does however remark that some flows of the Upper Steens have some similarities with the Birch Creek flows. Brueseke et al. (2007) describes the geochemical characteristics of the Upper Steens as $\mathrm{Ba}>300 \mathrm{ppm}$ and $\mathrm{K}_{2} \mathrm{O}$ concentrations greater than 1 wt\% (Figure 79) which both basaltic andesite units $\mathrm{Ba} 1$ and $\mathrm{Ba} 2$ have. The age of the Upper Steens is $\sim 16.57 \pm 0.04 \mathrm{Ma}$ (Bruseke et al., 2007) and would be stratigraphically conformable with the age of $16.13 \pm 0.11$ Ma for unit R1 (Hess, 2014). 


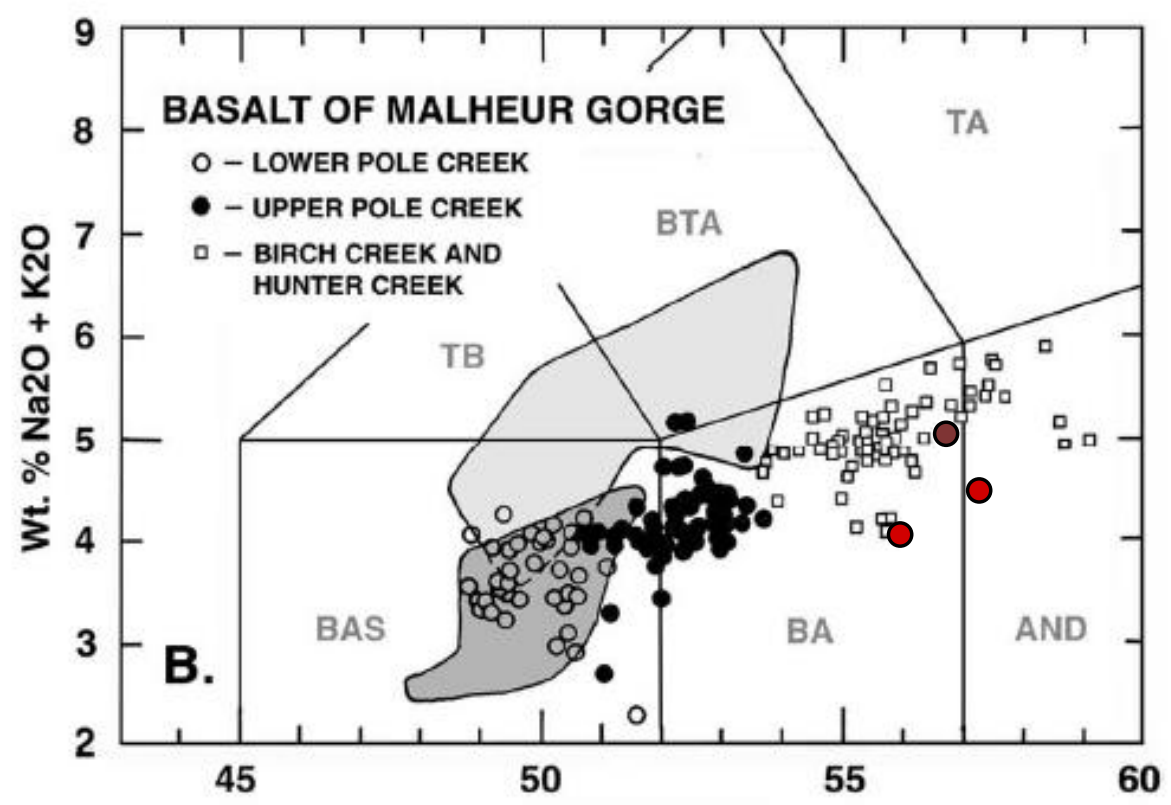

Figure 78: Plot of $\mathrm{Na} 2 \mathrm{O}+\mathrm{K} 2 \mathrm{O}$ vs $\mathrm{SiO} 2$ modified from Camp (2002). Samples from basaltic andesite units $\mathrm{Ba} 1$ (red) and $\mathrm{Ba} 2$ (dark red) overlain.

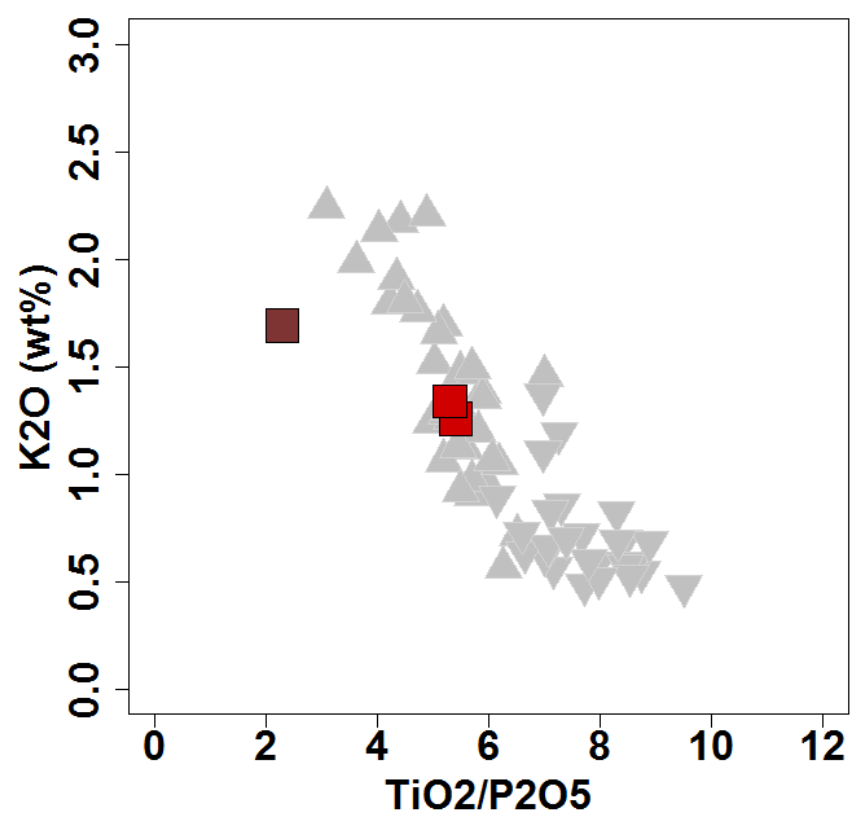

Figure 79: Plot ot $\mathrm{K} 2 \mathrm{O}$ vs. TiO2/P2O5 after Brueseke et al. (2007). Upper Steens: gray upward facing triangle, Lower Steens: gray down pointing triangle, Ba1: bright red, Ba2: dark red. 


\section{Trace element trends of Buchanan ash-flow tuff}

Three samples of rhyolitic tuff unit RT, previously mapped as the Buchanan ashflow tuff (Brown and McLean, 1980), have variability within select trace elements. This variability is accounted for by the mafic lithic fragments and pumice within the whole rock samples. Figure 80 shows the strongest variability with Sr, P and Ti. Similarities with samples are seen as enrichment in $\mathrm{Ba}, \mathrm{U}, \mathrm{K}$ and $\mathrm{Pb}$ relative to neighboring elements, and depletion in $\mathrm{Nb}-\mathrm{Ta}$. $\mathrm{Nd}-\mathrm{Eu}$ and $\mathrm{Tb}-\mathrm{Lu}$ are also similarly enriched between samples.

The grayed lines in Figure 80 show the trace element trends for samples of Wildcat Creek ash-flow tuff collected for a Master's degree thesis that is in progress from Sales (unpublished data). There is slightly more variability within samples of Wildcat

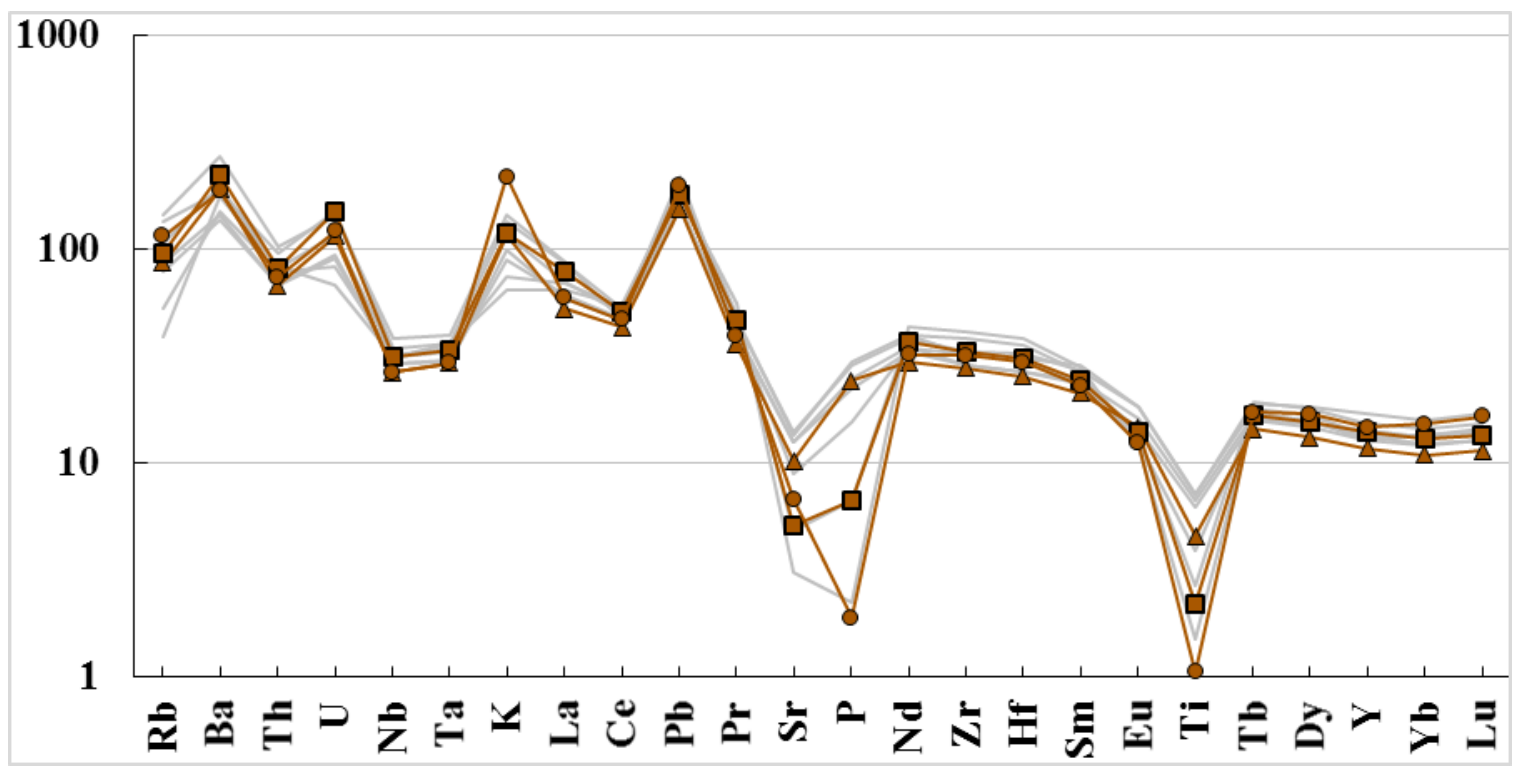

Figure 80: Multi-element diagram of samples within unit RT overlain on unpublished Wildcat Creek ashflow tuff data (grayed) (Sales, M.S. thesis in progress). RT samples B013: circle, B126: square and B191: triangle. Concentrations normalized to mantle values of Sun and McDonough (1989). 
Creek (this is to be expected with a large samples size and variable mafic inclusions within whole rock samples), however the trends of enrichment and depletion of individual elements are the same as RT samples. RT sample B191 closely follows the dominant trend of Sales' samples and the trace of sample B126 completely obscures the trace of one of the Wildcat Creek samples that were collected $\sim 50 \mathrm{~km}$ away, near Shumway reservoir (Sales, personal communication). Sample B013 from this study, marked with circles in Figure 80, has the greatest depletion in $\mathrm{P}$ which is also similar to one of the samples of Wildcat Creek tuff.

An Ar-Ar age date was determined by Hooper et al. (2002) of $15.9 \pm 0.2 \mathrm{Ma}$ for the Wildcat Creek ash-flow tuff, however he considered the date invalid due to inconsistencies with the stratigraphic age. If this date were accepted it would mean that eruptions at the Buchanan rhyolite complex and emplacement of the Wildcat Creek ashflow tuff were nearly coeval. 


\section{Geologic map of Buchanan rhyolite complex}

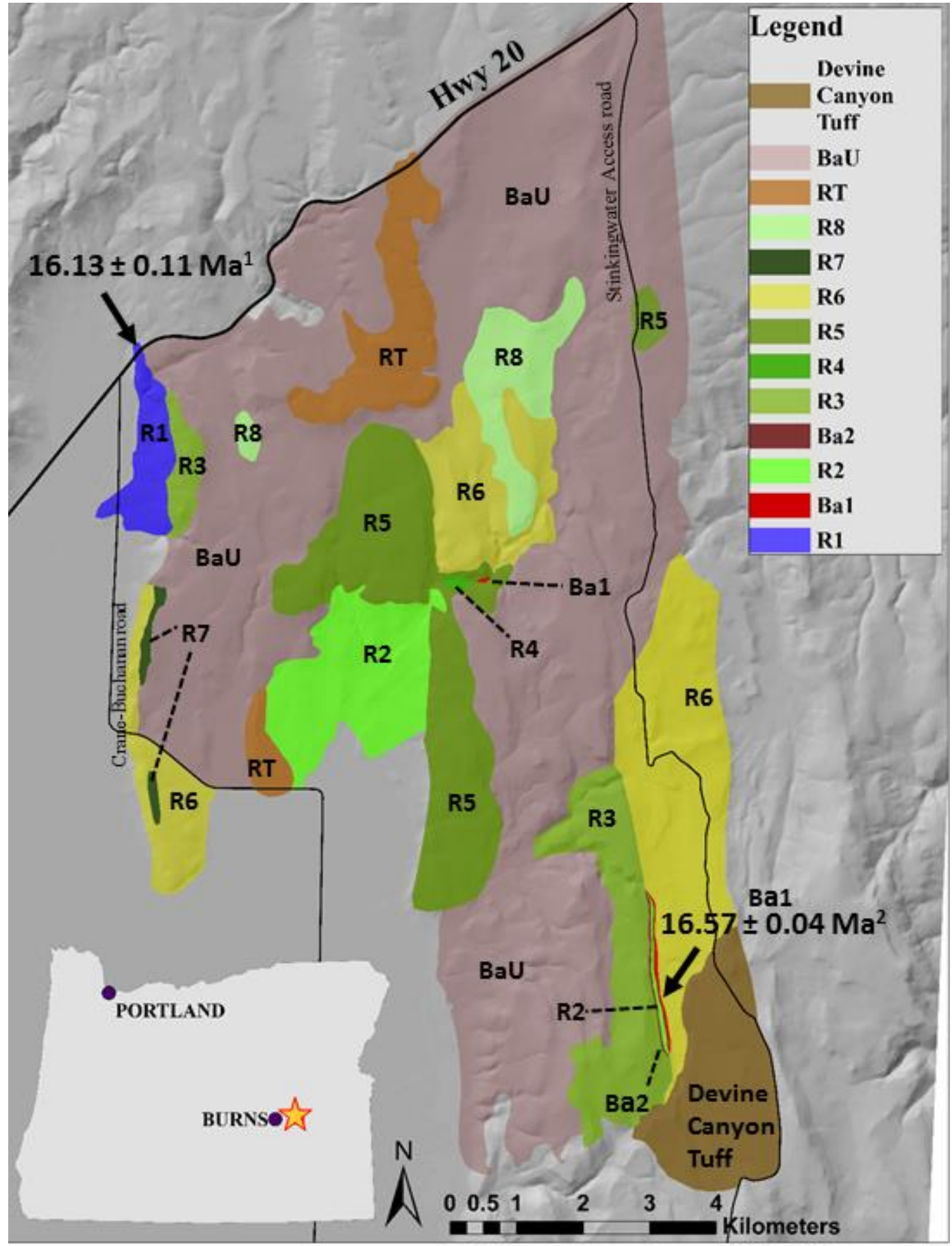

Figure 81: Geologic map of Buchanan rhyolite complex. Location of study area indicated with a star on inset map of Oregon. 1: Hess (2014), 2: (Bruseke et al., 2007). Map scale: 1:35,000 


\section{Geologic timeline of Buchanan rhyolite complex}

The Buchanan rhyolite complex consists of at least eight rhyolite eruptive units, seven of which are flows or domes and the other is a local pyroclastic unit. The underlying basaltic andesite unit Ba1 has been loosely correlated with basalts of the Upper Steens and is $\sim 16.57 \pm 0.04 \mathrm{Ma}$ (Brueseke et al., 2007). Rhyolite unit R1 has an Ar-Ar age date from Hess (2014) of $16.13 \pm 0.11 \mathrm{Ma}$ and is thought to be the earliest rhyolite unit of the complex. Overlying the rhyolite eruptive units are several thin basalt flows, one of which has an age of 13.79 \pm 0.09 Ma from Streck (unpublished data), the Devine Canyon Tuff at 9.7 Ma (Hooper et al., 2002), and the Buchanan ash-flow tuff, correlated to the Wildcat Creek ash-flow tuff dated by Hooper et al. (2002) at $15.9 \pm 0.2$ but considered invalid.

Age constraints on the initiation of rhyolite volcanism at Buchanan rhyolite complex are better defined than constraints on the conclusion of rhyolite volcanism. Rhyolitic eruptions began $\sim 16.13 \pm 0.11 \mathrm{Ma}$ (Hess, 2014), and if the date by Hooper et al. (2002) of $15.9 \pm 0.2 \mathrm{Ma}$ is accepted for the Wildcat Creek ash-flow tuff, emplacement of all rhyolite units would have been over a short amount of time and possibly coeval with the eruption of the Wildcat Creek ash-flow tuff. A younger age for the Wildcat Creek ash flow tuff is preferred by Hooper et al. (2002) and by this study, but more data are needed.

The early age date of $\sim 16.13 \pm 0.11 \mathrm{Ma}$ (Hess, 2014) suggests that the Buchanan rhyolite complex is an early eruptive center associated with the impingement of the Yellowstone hotspot. This rhyolite volcanic center is the western most silicic center yet identified associated with initiation of Yellowstone related volcanism. 


\section{Dooley Mountain Rhyolite Complex}

\section{Results}

\section{Lithologic and petrographic characteristics of units}

Over 100 hand samples from the Dooley Mounatin rhyolite complex were

collected in the field. Approximate locations of all hand samples shown in Figure 82.

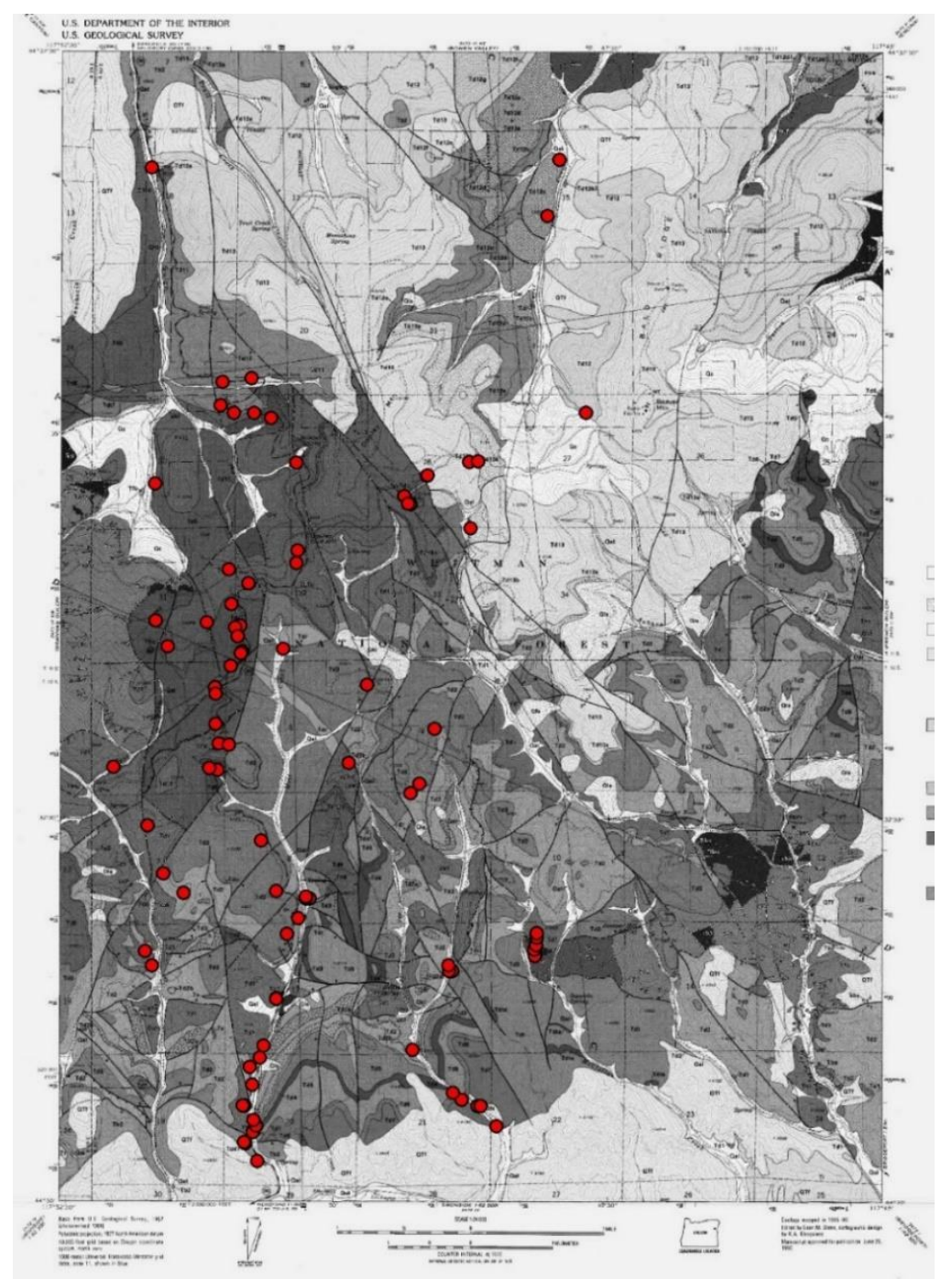

Figure 82: Location map for hand samples collected at Dooley Mountain rhyolite complex. Map modified from Evan (1992). 
At least five groups of rhyolite are observed from macroscopic characteristics of hand samples. Major phenocryst phases present and visible with either no magnification or with a 10x hand lens include quartz, feldspar and amphibole. Phenocryst abundance ranges from $0-15 \%$ and size varies from much less than $1 \mathrm{~mm}$ to $3 \mathrm{~mm}$. Samples also vary from vitric to devitrified with spherulites up to $3 \mathrm{~cm}$. The five groups identified in the field are described as follows and are later correlated with geochemical groups:

- Aphyric, vitric to devitrified

- Porphyritic, $\sim 1 \%$ quartz and feldspar phenocrysts $<1 \mathrm{~mm}$, vitric to devitrified

- Porphyritic, $\sim 5 \%$ feldspar phenocrysts up to $2 \mathrm{~mm}$, vitric to devitrified

- Porphyritic, 5\% feldspar and amphibole up to $2 \mathrm{~mm}$, vitric to devitrified

- Porphyritic, $\sim 10-15 \%$ feldspar up to $3 \mathrm{~mm}$, vitric to devitrified

In addition to the above five groups, at least three distinct basalt flows and four tuff outcrops were identified in the field. The major phenocryst phases identified in the basalt units include feldspar and olivine. Phenocryst abundance ranges from $\sim 1-30 \%$ and size varies from $<1 \mathrm{~mm}$ to $2 \mathrm{~mm}$. Three basalt units are described as follows:

- Porphyritic, $\sim 1 \%$ feldspar phenocrysts $<1 \mathrm{~mm}$, medium-dark gray, locally vesiculated

- Porphyritic, $\sim 3-5 \%$ feldspar and olivine phenocrysts up to $3 \mathrm{~mm}$, dark gray

- Porphyritic, $\sim 15-30 \%$ feldspar phenocrysts up to $10 \mathrm{~mm}$, black

The four tuff units are differentiated as follows: 
- Many undeformed pumice up to $10 \mathrm{~cm}$, contains white lithic fragments, phenocrysts are absent, light gray, incipiently welded

- Pumice/fiamme up to $5 \mathrm{~cm}$, mafic lithic fragments up to $1 \mathrm{~cm}, \sim 2 \%$ feldspar phenocrysts up to $2 \mathrm{~mm}$, black-dark gray

- Fiamme up to $3 \mathrm{~cm}$, lithic fragments up to $5 \mathrm{~mm}, 22 \%$ feldspar phenocrysts, tan-dark gray

- Deformed pumice up to $2 \mathrm{~cm}$, obsidian clasts up to $2 \mathrm{~cm}, 0-5 \%$ feldspar phenocrysts

\section{Stratigraphic relationships}

Identifying widespread stratigraphic relationships in the field is difficult due to similar lithology of units confirming observations by Evans (1992). Local stratigraphic relationships were observed however and are later paired with the results of geochemical analysis.

In roadcut, along highway 245 near latitude 44.5259, longitude -117.8428, a brecciated aphyric unit (samples EJ-23B, DM44) overlies a massive, porphyritic, 1\% phenocryst unit (samples EJ-23A, DM48), seen in Figure 83. 


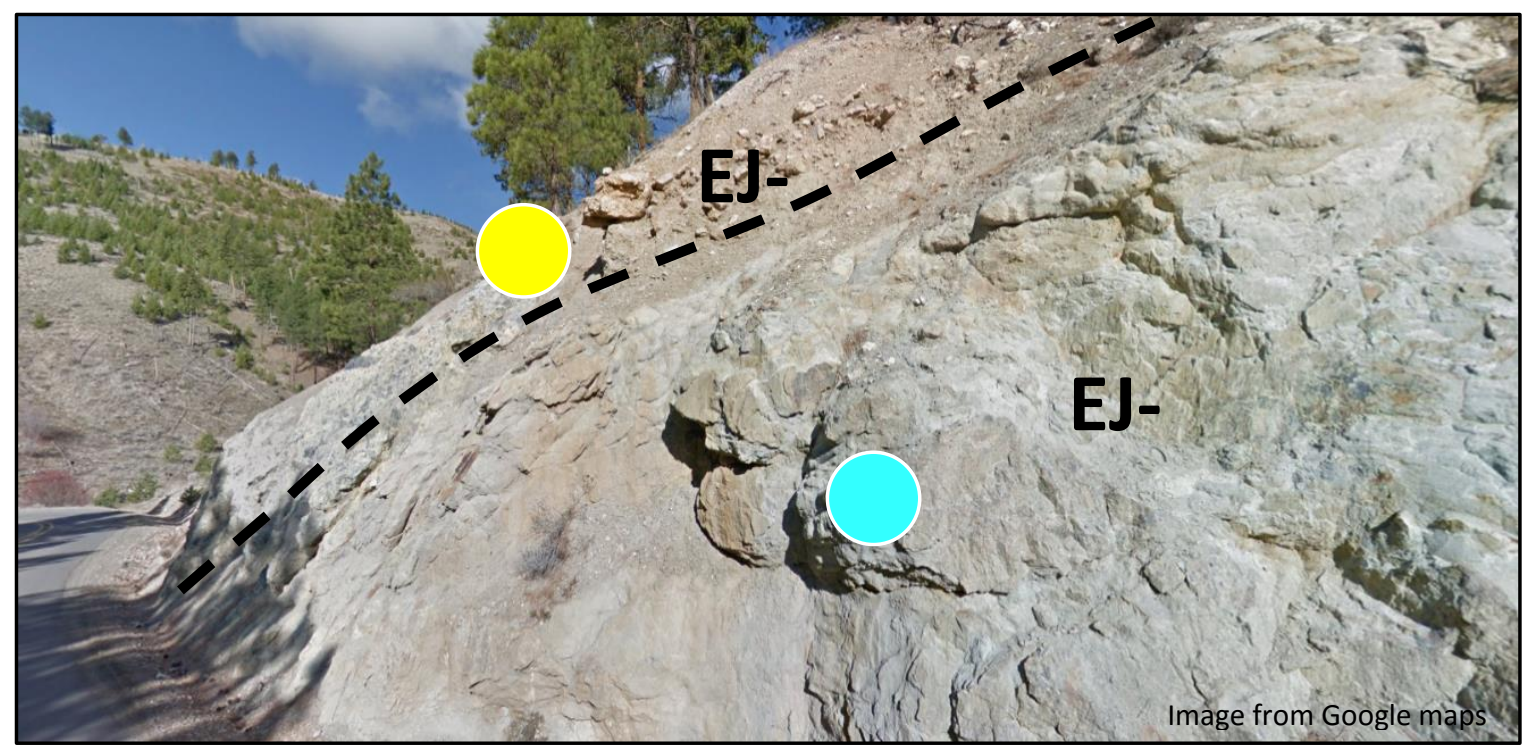

Figure 83: Photograph of sharp contact between brecciated aphyric unit (EJ-23B) overlying massive porphyritc $<1 \%$ phenocryst unit (EJ-23A). Location of photograph at latitude 44.5259 , longitude 117.8428. Image from Google maps.

Along highway 245, near latitude 44.5896, longitude -117.8513, an ash and pumice dike (sample MS-11-22DR) cross cuts a massive rhyolite flow with $~ 5 \%$ feldspar phenocrysts (sample DM202), seen in Figure 84, below. 


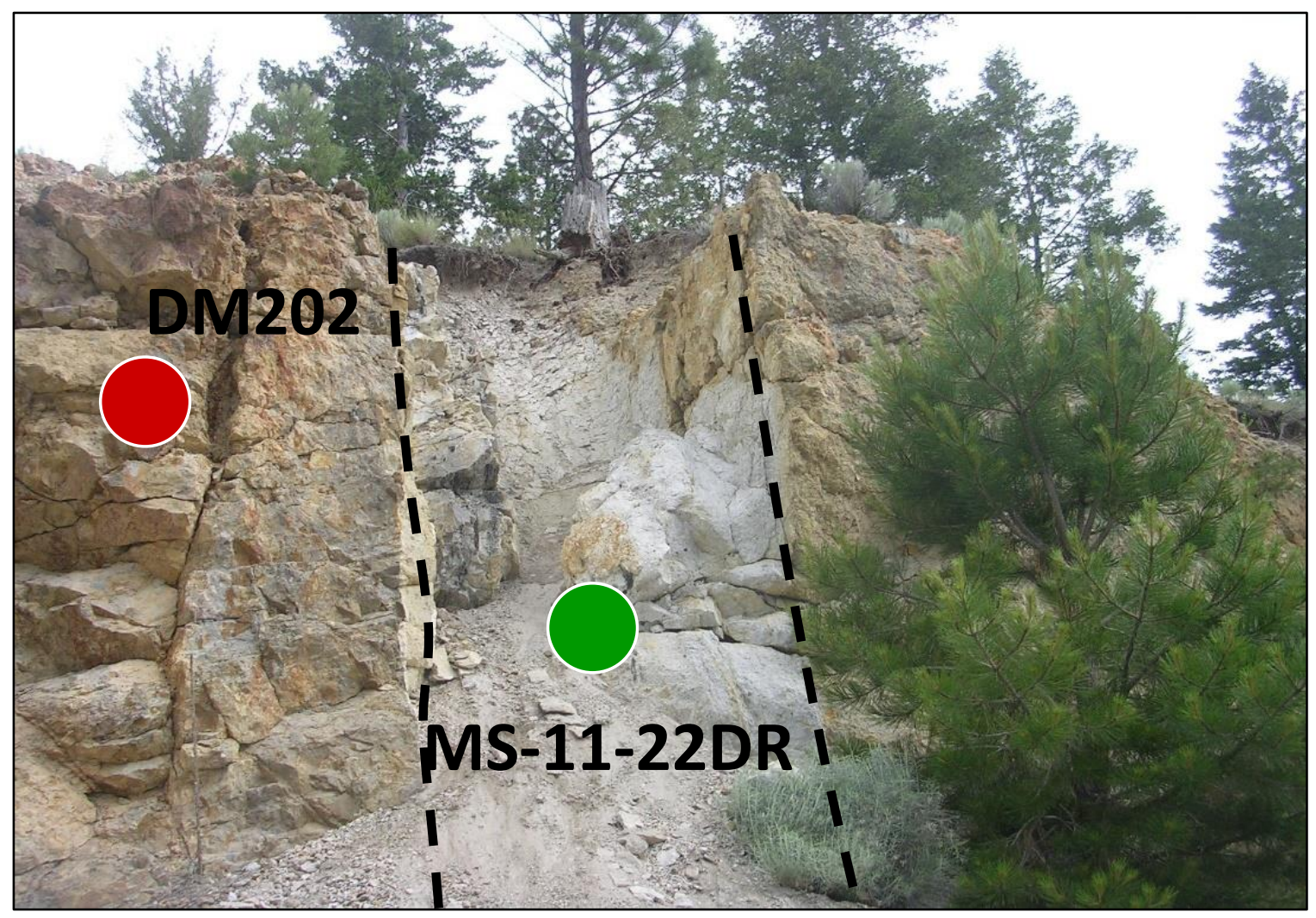

Figure 84: Photograph of cross cutting relationship of tuff dike (MS-11-22DR) through a massive rhyolite unit (DM202). Location of photograph at latitude 44.5896, longitude -117.8513. Tuff dike is stratigraphically younger than massive rhyolite unit.

In outcrop, along NF-1118, near latitude 44.5113, longitude -117.8130, an

eruptive sequence is exposed with a breccia at the base (sample DM265A), ash and lapilli fall in the middle (samples DM265) and a glassy breccia at the top (sample DM265A), seen in Figure 85. To the south of this exposure, massive rhyolite cliffs (sample DM264, Figure 86) are either continuous with DM265A, with DM265A as a basal breccia, or overlies this sequence. 


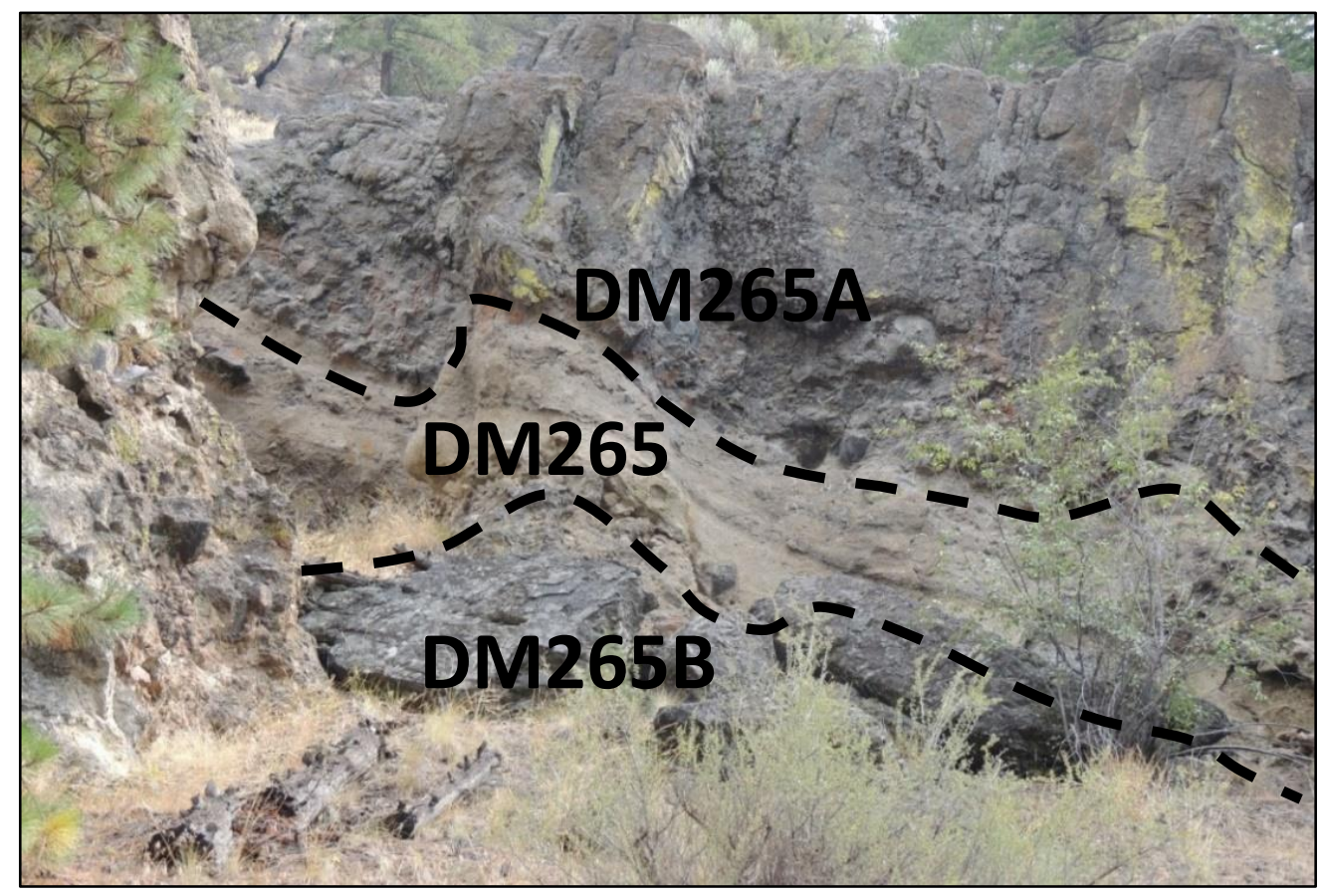

Figure 85: Photograph of vitrophyric breccia (DM265A) overlying lapilli and ash fall (DM265) and breccia (DM265B). Location of photograph at latitude 44.5222, longitude -117.8139. 265A is either continuous as the basal breccia or underlies a massive rhyolite unit directly to the south of this photo (sample DM264).

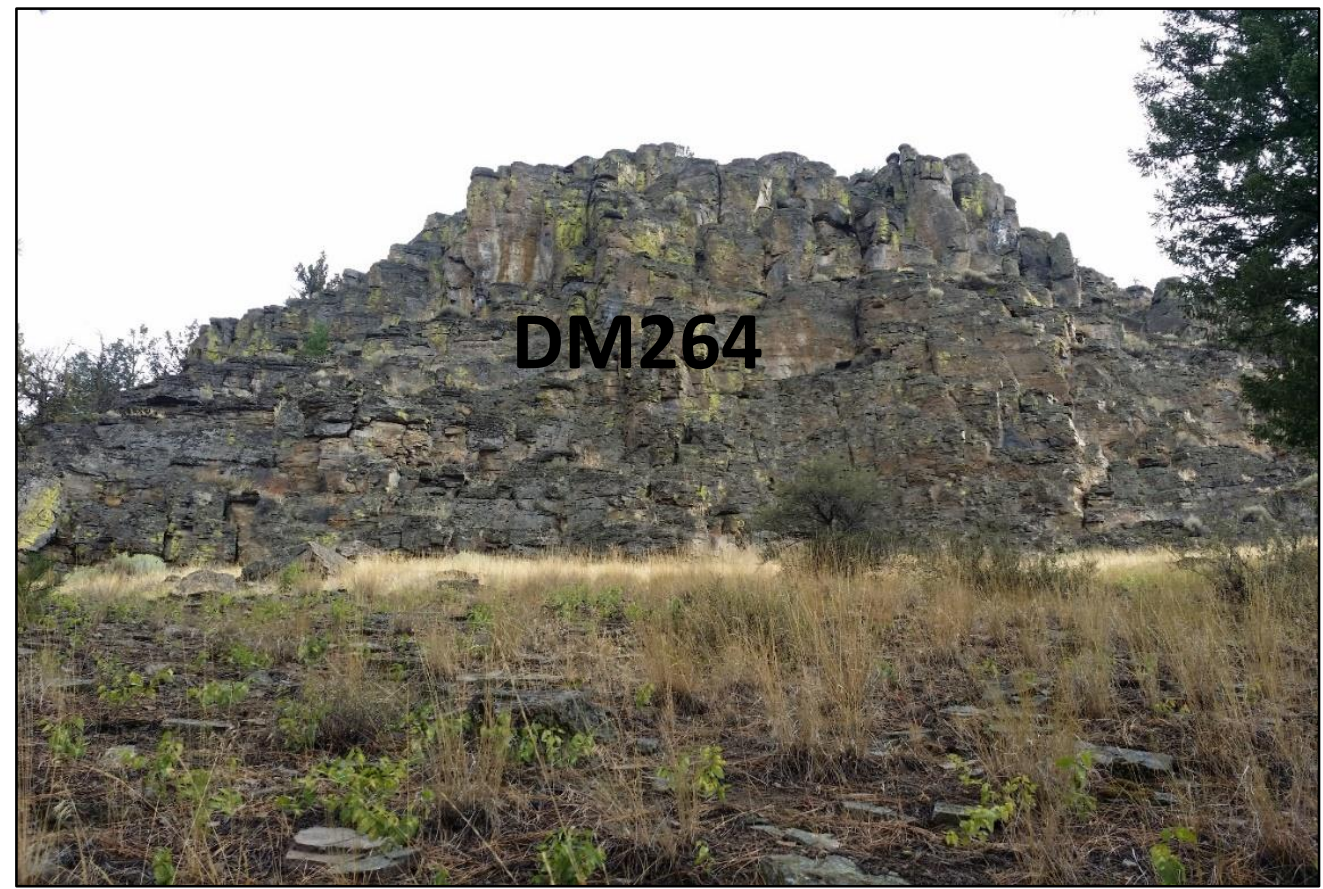

Figure 86: Photograph of massive rhyolite cliffs (DM264). Location of photograph at latitude 44.5105, longitude -117.8109. 
Approximately $0.5 \mathrm{~km}$ south of NF-040 near latitude 44.5274 , longitude 117.8028 a stratigraphic sequence is exposed along the southern slope of a hill. The lowest unit in the sequence is the Burnt River schist (DM254). Overlying the Burnt River schist are two basalt units, one with 3\% phenocrysts (DM255A) and one with 15\% phenocrysts (DM255B), however the stratigraphic relationship between the two basalts is unclear. Overlying the basalt units is a welded lithic tuff unit with $2 \%$ phenocrysts (DM256). Capping the sequence is an aphyric rhyolite unit with a glassy base (vitrophyre) and devitrified interior (DM258 and DM259).

\section{Geochemical groups}

\section{Rhyolitic Units}

Geochemical groups of silicic units are identified by pairing major and trace element analysis results with distinct stratigraphic relationships from two locations. Samples EJ-23B, EJ-23A (Hess, 2014), MS-13-22DR (from Streck, unpublished data) and DM202 are identified with light blue, yellow, green and red, respectively, as seen in Figure 83 and 84 . The bivariate plots of major element oxides or trace elements vs. $\mathrm{TiO}_{2}$ display seven geochemical groups (Figure 87), four rhyolite lava flows and geochemically related local tuffs, and three geochemically distinct tuffs.

The plot of $\mathrm{SiO}_{2}$ vs. $\mathrm{TiO} 2$ (Figure 87) shows a slight increase in $\mathrm{TiO}_{2}$ with decreasing $\mathrm{SiO}_{2}$, however our baseline samples for establishing stratigraphic relationships show similar $\mathrm{SiO}_{2}$ content at differing $\mathrm{TiO}_{2}$. Because of this, $\mathrm{SiO}_{2}$ and other major element oxides are not very helpful in defining the geochemical groups. The best 
discriminator for defining groups was found in plots of trace elements against $\mathrm{TiO}_{2}$ indicating seven groups (Figure 87 and Table 11).

Table 11: Geochemical ranges for $\mathrm{TiO} 2(\mathrm{wt} \%)$ and select trace elements (ppm) for rhyolite groups at Dooley Mountain rhyolite complex.

\begin{tabular}{ccccccc}
\hline \hline Group & $\mathrm{TiO} 2$ & $\mathrm{Zr}$ & $\mathrm{La}$ & $\mathrm{Lu}$ & $\mathrm{Rb}$ & $\mathrm{Nb}$ \\
\hline $\mathrm{R} 1(\mathrm{n}=4)$ & $0.05-0.06$ & $75-87$ & $23-25$ & $0.51-0.54$ & $116-131$ & $9-10$ \\
$\mathrm{R} 2(\mathrm{n}=3)$ & $0.11-0.12$ & $172-184$ & $36-40$ & $0.55-0.58$ & $93-111$ & $9-10$ \\
$\mathrm{R} 3(\mathrm{n}=6)$ & $0.28-0.34$ & $303-389$ & $35-45$ & $0.72-0.86$ & $78-94$ & $10-16$ \\
$\mathrm{R} 4(\mathrm{n}=10)$ & $0.15-0.21$ & $216-323$ & $36-41^{*}$ & $0.65-0.90$ & $90-101$ & $13-15$ \\
$\mathrm{~T} 1(\mathrm{n}=1)$ & 0.19 & 387 & 37 & 1.49 & 64 & 20 \\
$\mathrm{~T} 2(\mathrm{n}=1)$ & 0.28 & 362 & 39 & 1.05 & 62 & 20 \\
$\mathrm{~T} 3(\mathrm{n}=1)$ & 0.57 & 310 & 35 & 1.1 & 71 & 14 \\
\hline
\end{tabular}

* one outlier in group four has $\mathrm{La}>61 \mathrm{ppm}$; $\mathrm{n}=$ number of samples

These rhyolitic geochemical groups can roughly be correlated with petrographic groups. Group R1 has 0 to $<1 \%$ quartz and alkali feldspar phenocrysts and Group R2 has $\sim 3$ to $5 \%$ plagioclase, alkali feldspar and minor amphibole phenocrysts. Group R3 has the greatest variability in phenocryst abundance with 0 to $10 \%$ plagioclase and alkali feldspar and Group R4 has minor amounts, 0 to 1\%, of quartz and alkali feldspar phenocrysts. Tuff groups T1 and T2 are described above as containing fiamme up to $3 \mathrm{~cm}$, lithic fragments up to $5 \mathrm{~mm}$ and tan-dark gray. Group T3 has more mafic pumice/fiamme up to $5 \mathrm{~cm}$ and is black-dark gray. 

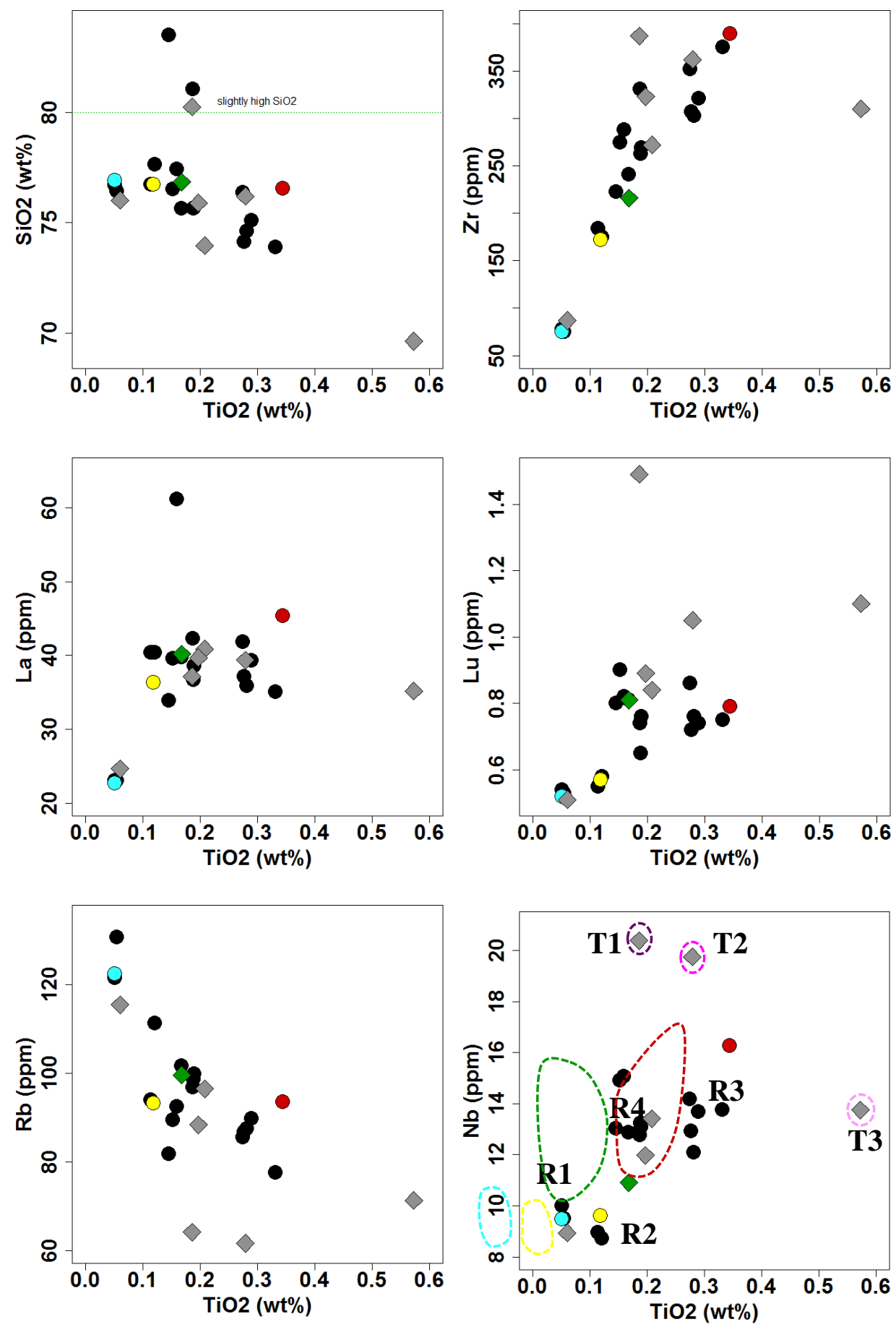

Figure 87: Bivariate plots of $\mathrm{SiO}_{2}$ and 5 trace elements vs. $\mathrm{TiO}_{2}$.Sample EJ-23-A (Yellow) overlies EJ-23-B (light blue), sample MS-11-22DR (green) crosscuts DM202 (red). Samples from rhyolite flow/dome deposits are indicated with circles. Pyroclastic deposits are indicated by diamonds. Geochemical groups are indicated by dashed lines in plot of $\mathrm{Nb}$ vs. $\mathrm{TiO}_{2}$. 


\section{Multi-element diagrams for rhyolite groups}

Multi-element diagrams for each geochemical group are displayed below with average values for each group. Additional multi-element diagrams with average unit values in relation to all samples of a unit can be found in Appendix B-3.

\section{Rhyolite R1:}

Group one includes four samples: DR4, EJ23B, DM247 and DM258. Defining trace element characteristics as seen in multi-element normalization diagram (Figure 88) include a negative $\mathrm{Ba}$ anomaly compared to $\mathrm{Rb}$ and $\mathrm{Th}$, a negative $\mathrm{Zr}$ anomaly compared to $\mathrm{Nd}$ and $\mathrm{Hf}$, less enrichment of $\mathrm{La}, \mathrm{Ce}, \mathrm{Sr}$ and Eu than other groups, less enrichment of $\mathrm{Tb}-\mathrm{Lu}(<10)$ than the other groups and depletion of $\mathrm{Ti}(<<1)$ and $\mathrm{P}(<1)$.

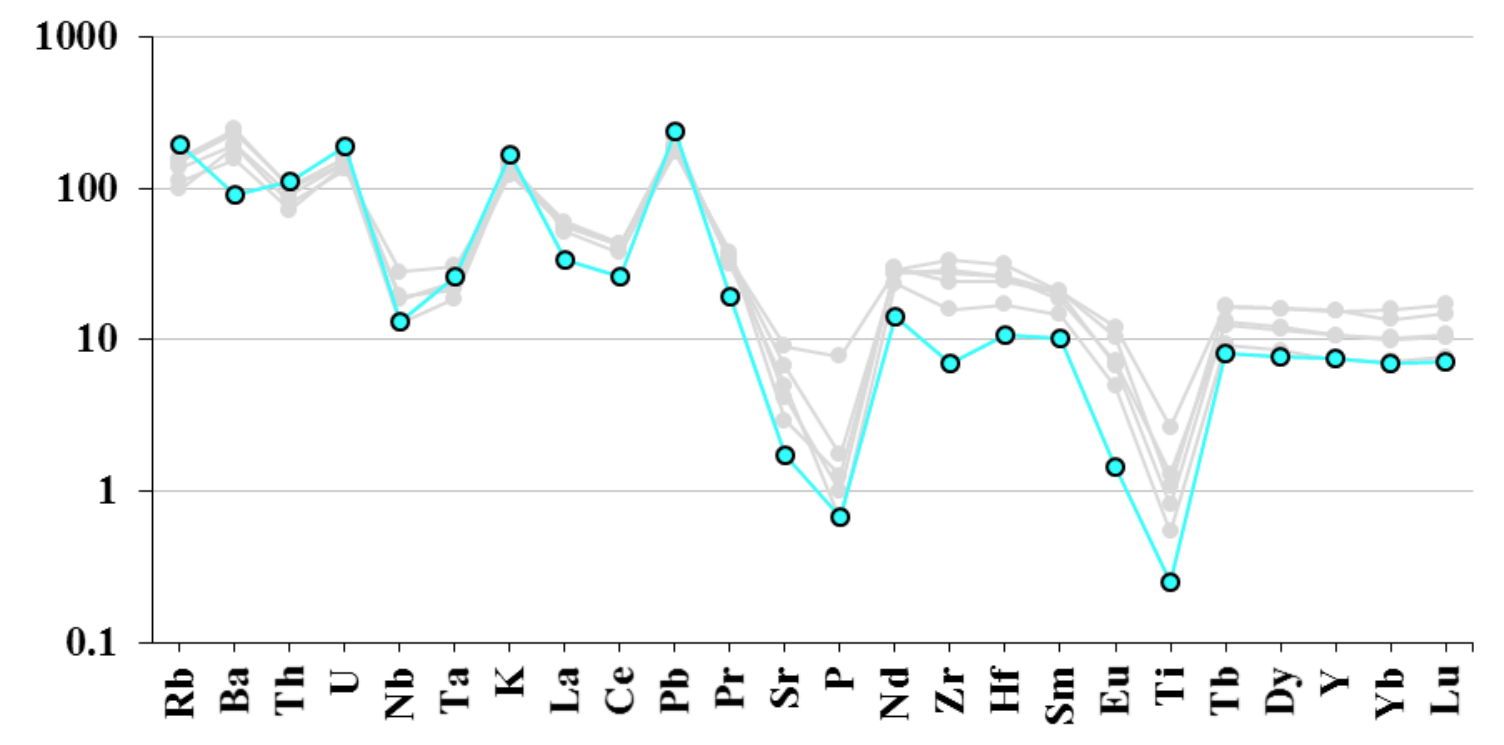

Figure 88: Multi-element diagram of average geochemical group R1 (light blue) in comparison to average of other groups (grayed). Concentrations normalized to mantle values of Sun and McDonough (1989). Additional multi-element diagrams with average unit value overlain on within-group samples can be found in Appendix B-3. 


\section{Rhyolite R2:}

Group two includes three samples: EJ-23A, DM234 and DM235. Defining trace element characteristics as seen in multi-element diagram (Figure 89) include a positive $\mathrm{Ba}$ anomaly compared to $\mathrm{Rb}$ and $\mathrm{Th}$, a slight negative $\mathrm{Zr}$ anomaly compared to $\mathrm{Nd}$ and $\mathrm{Hf}$, less enrichment in Ta, relative low concentrations of Tb-Lu at $\sim 10$ or below and depletion of $\mathrm{Ti}(<1)$ and $\mathrm{P}(<1)$.

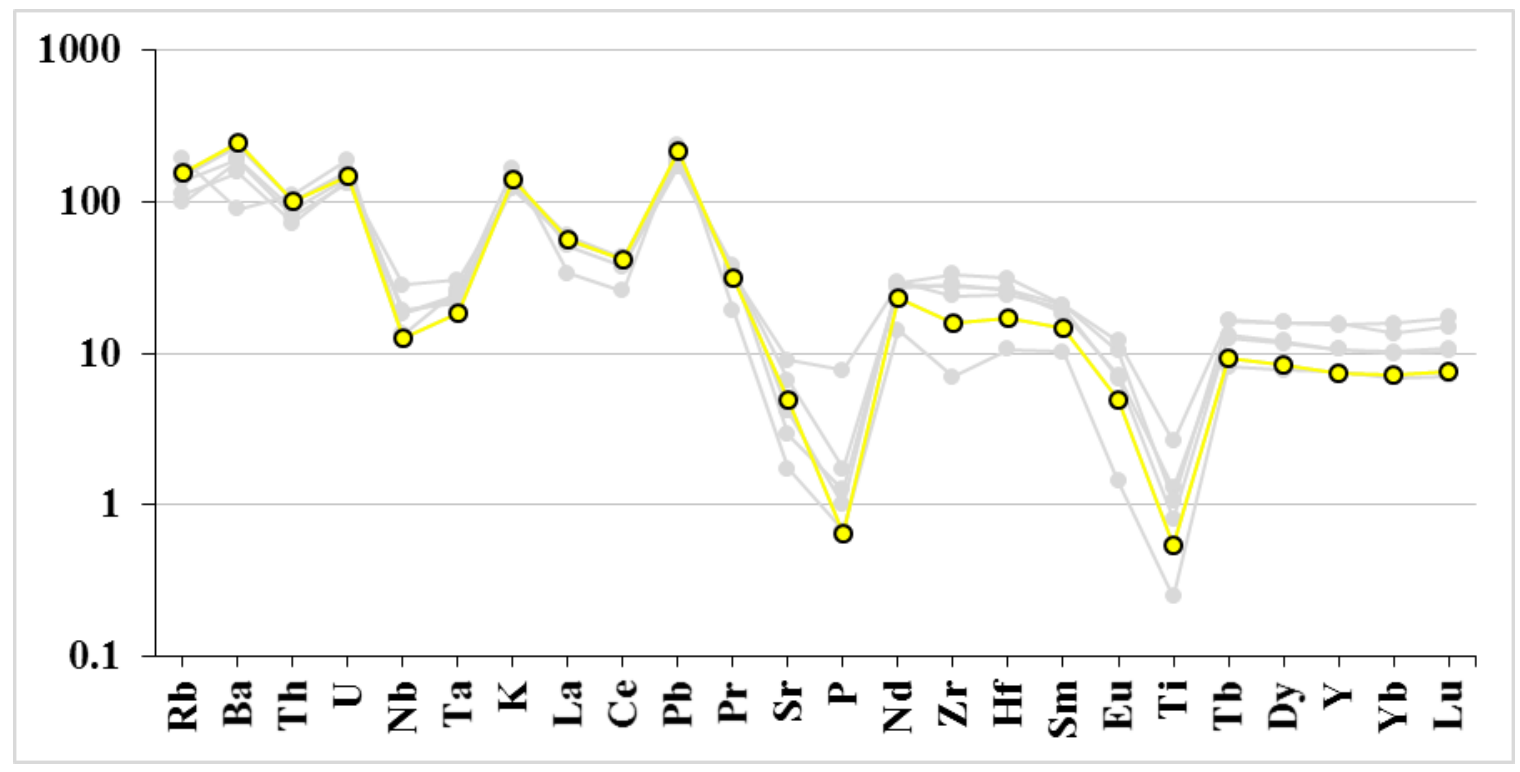

Figure 89: Multi-element diagram of average geochemical group R2 (yellow) in comparison to average of other groups (grayed). Concentrations normalized to mantle values of Sun and McDonough (1989). Additional multi-element diagrams with average unit value overlain on within-group samples can be found in Appendix B-3. 


\section{Rhyolite R3:}

Group three includes six samples: DR2, DM202, DM220, DM240, DM241 and

DM250. Defining trace element characteristics as seen in multi-element diagram (Figure

90) include a positive $\mathrm{Ba}$ anomaly compared to $\mathrm{Rb}$ and $\mathrm{Th}$, minor $\mathrm{Zr}$ and $\mathrm{Hf}$ enrichment

comparable to $\mathrm{Nd}$ and $\mathrm{Sm}$, less depletion of $\mathrm{Eu}$, higher $\mathrm{Tb}-\mathrm{Lu}(>10)$, and less depletion of $\mathrm{P}$ and Ti than group 1 or 2.

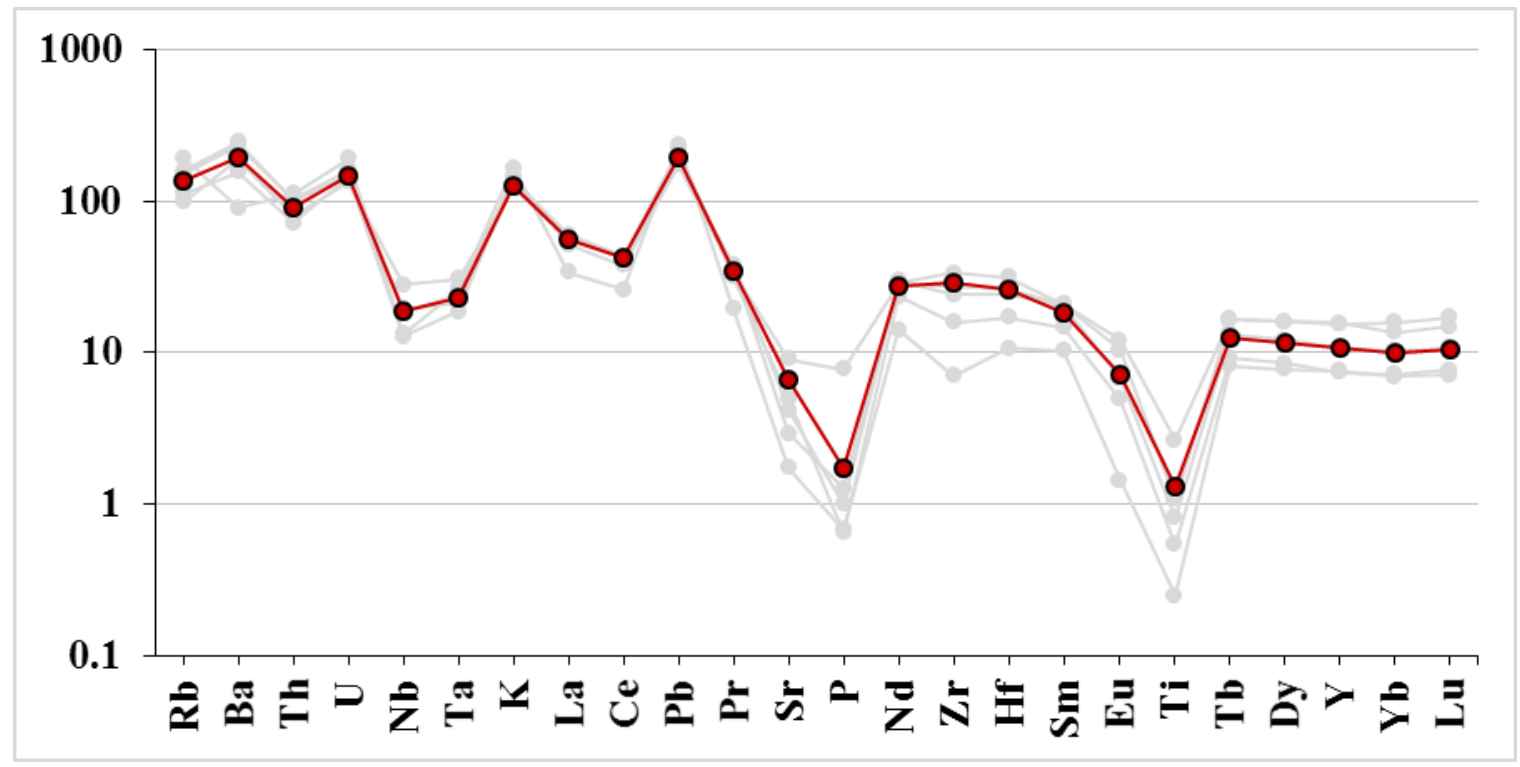

Figure 90: Multi-element diagram of average geochemical group R3 (red) in comparison to average of other groups (grayed). Concentrations normalized to mantle values of Sun and McDonough (1989). Additional multi-element diagrams with average unit value overlain on within-group samples can be found in Appendix B-3. 


\section{Rhyolite R4:}

Group four includes ten samples: MS-11-22DR, DM044B, DM048, DM223, DM238, DM264, DM265A, DM265, DM265B and DM273A. Defining trace element characteristics as seen in multi-element diagram (Figure 91) include a positive $\mathrm{Ba}$ anomaly compared to $\mathrm{Rb}$ and $\mathrm{Th}$, lower $\mathrm{Zr}$ and $\mathrm{Hf}$ than group 3, Ti depletion $\sim 1$ and enrichment of Tb-Lu >10. Two samples, DM044B and DM048, have outlier values for $\mathrm{Ba}, \mathrm{Pb}$ and $\mathrm{Sr}$, likely resulting from post emplacement alteration.

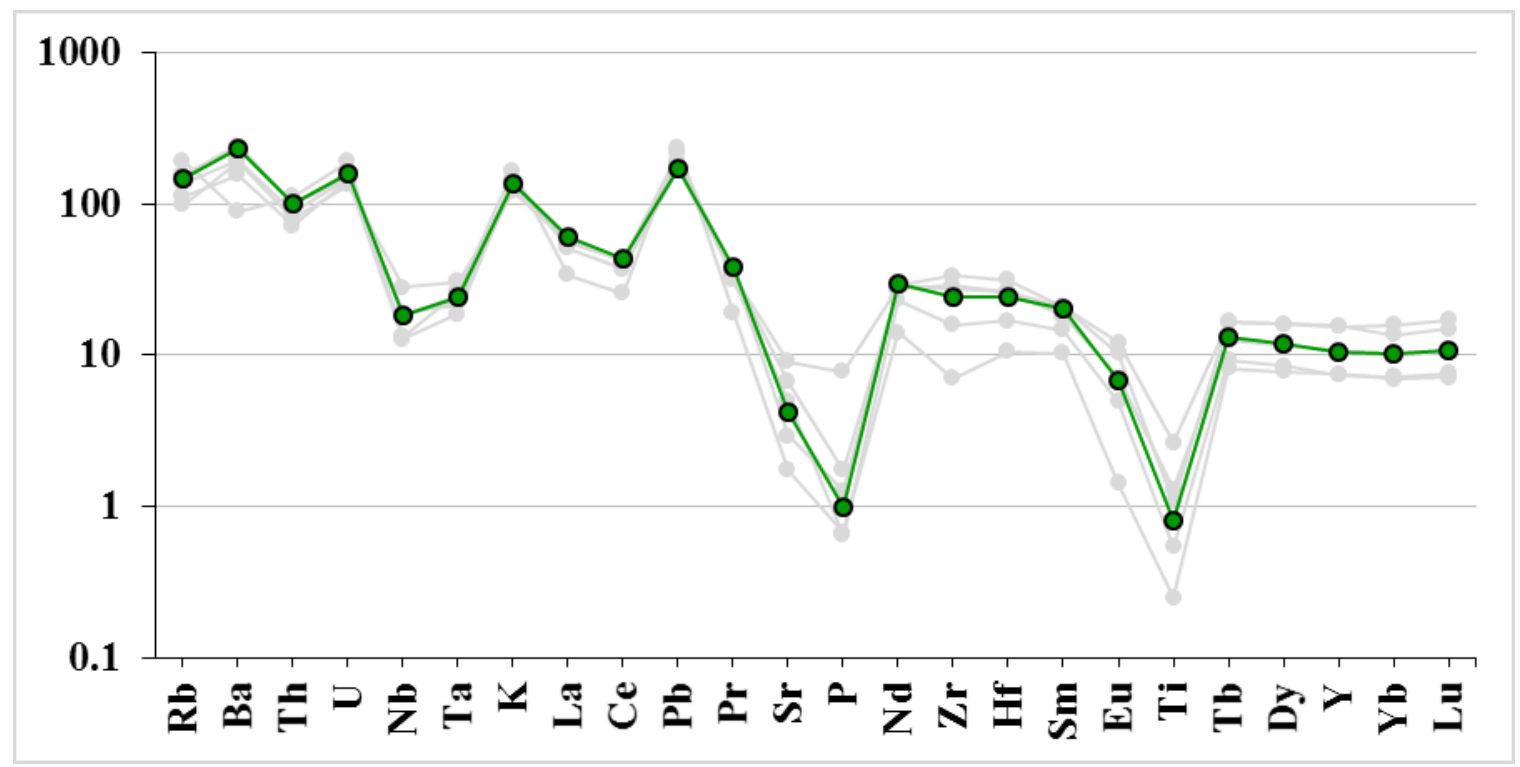

Figure 91: Multi-element diagram of average geochemical group R4 (green) in comparison to average of other groups (grayed). Concentrations normalized to mantle values of Sun and McDonough (1989).

Additional multi-element diagrams with average unit value overlain on within-group samples can be found in Appendix B-3. 


\section{Tuff Groups:}

The three tuff groups exposed in the study area have geochemical signatures unrelated to the rhyolite units and can be further discriminated and identified. Comparison with geochemical data for the four eruptive units of the Dinner Creek Tuff (Streck et al., 2015) indicate that the three groups, T1, T2 and T3, correlate with eruptive units 1 (DIT1), 2 (DIT2) and 4 (DIT4) of the Dinner Creek Tuff, respectively (Figure 92).

DIT1 and Dooley Mountain volcanic complex unit T1 have low $\mathrm{TiO}_{2}(<\sim 0.2$ wt\%), low $\mathrm{Sr}(<\sim 40 \mathrm{ppm})$, high $\mathrm{Y}(>\sim 80 \mathrm{ppm})$ and high $\mathrm{Nb}(>\sim 20 \mathrm{ppm})$. High silica varieties of DIT2 $\left(\mathrm{SiO}_{2}>\sim 74 \mathrm{wt} \%\right)$ and $\mathrm{T} 2$ have $\mathrm{TiO}_{2}$ between $\sim 0.2-0.3 \mathrm{wt} \%, \mathrm{Sr} \sim 80-120$ ppm and $\mathrm{Nb} \sim 20-21$. The correlation of DIT4 and T3 are best seen in the plot of Nb vs. Sr (Figure 92) and in handsample. The variability of lithic fragments and mafic pumice within the analyzed sample of unit T3 and samples of DIT4 may have contributed to the differences in $\mathrm{TiO}_{2}$ and $\mathrm{Y}$. 

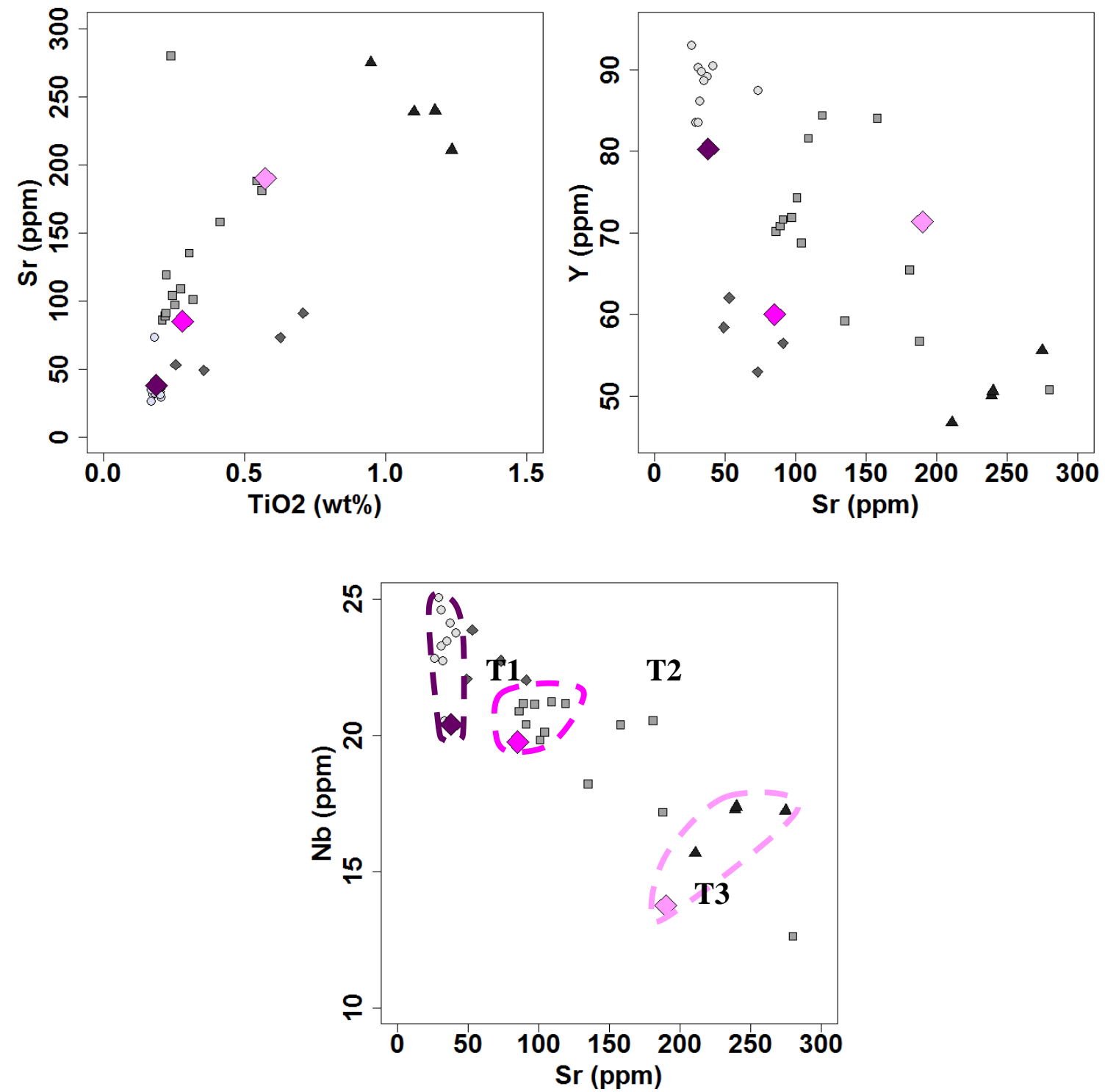

Figure 92: Bivariate plots of tuff units T1 (magenta), T2 (dark pink) and T3 (light pink), compared to Dinner Creek Tuff eruptive units. Dinner Creek Tuff eruptive units DIT 1 (light gray circles), DIT 2 (gray squares), DIT 3 (dark gray diamonds) and DIT 4 (black triangles) defined by Streck (2015). T1 is comparable to DIT 1, T2 is comparable to DIT 2 and T3 is comparable to DIT 4. Dinner Creek Tuff data from Streck (2015)

Multi-element diagrams (Figure 93, 94 and 95) of units T1, T2 and T3 compared to DIT1, DIT2 and DIT4 display the similarities in trace element enrichment between the average values of Dinner Creek Tuff units and samples from the study area. 


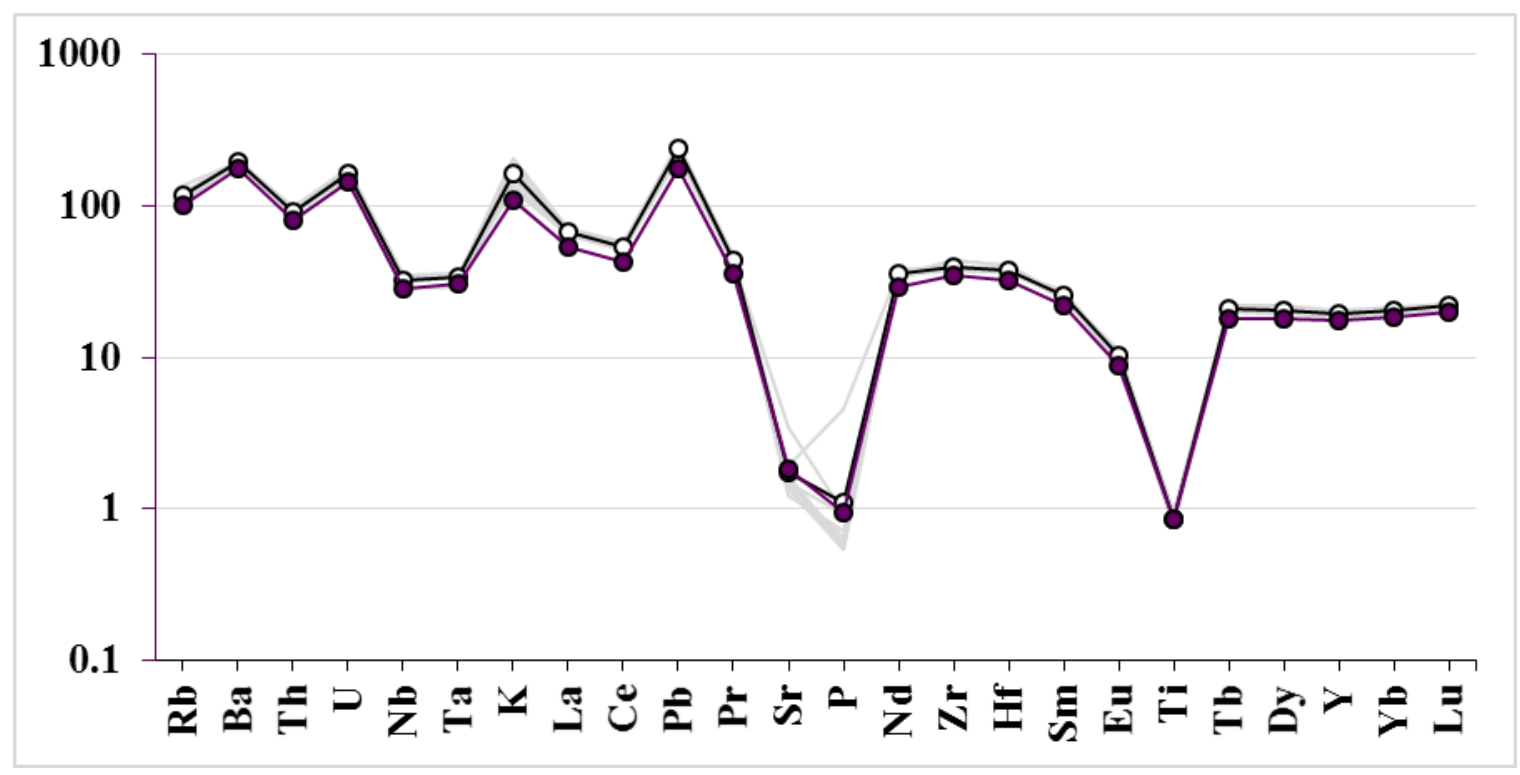

Figure 93:Multi-element diagram of average geochemical group T1 (magenta) in comparison to average of DIT1 (black line w/ black circles) and within group DIT1 samples (grayed). DIT data from Streck et al. (2015). Concentrations normalized to mantle values of Sun and McDonough (1989).

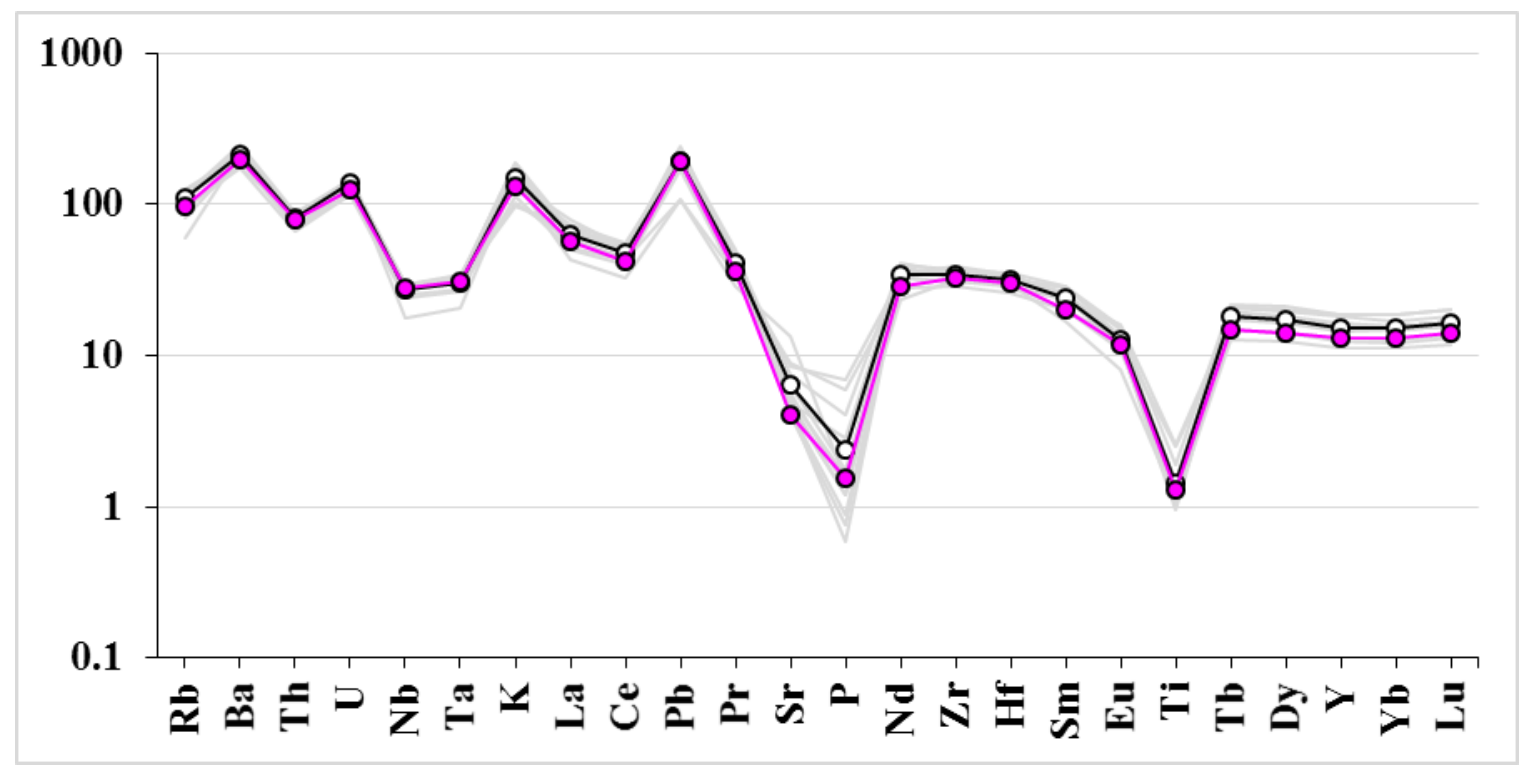

Figure 94: Multi-element diagram of average geochemical group T2 (dark pink) in comparison to average of DIT2 (black line w/ black circles) and within group DIT2 samples (grayed). DIT data from Streck et al. (2015). Concentrations normalized to mantle values of Sun and McDonough (1989) 


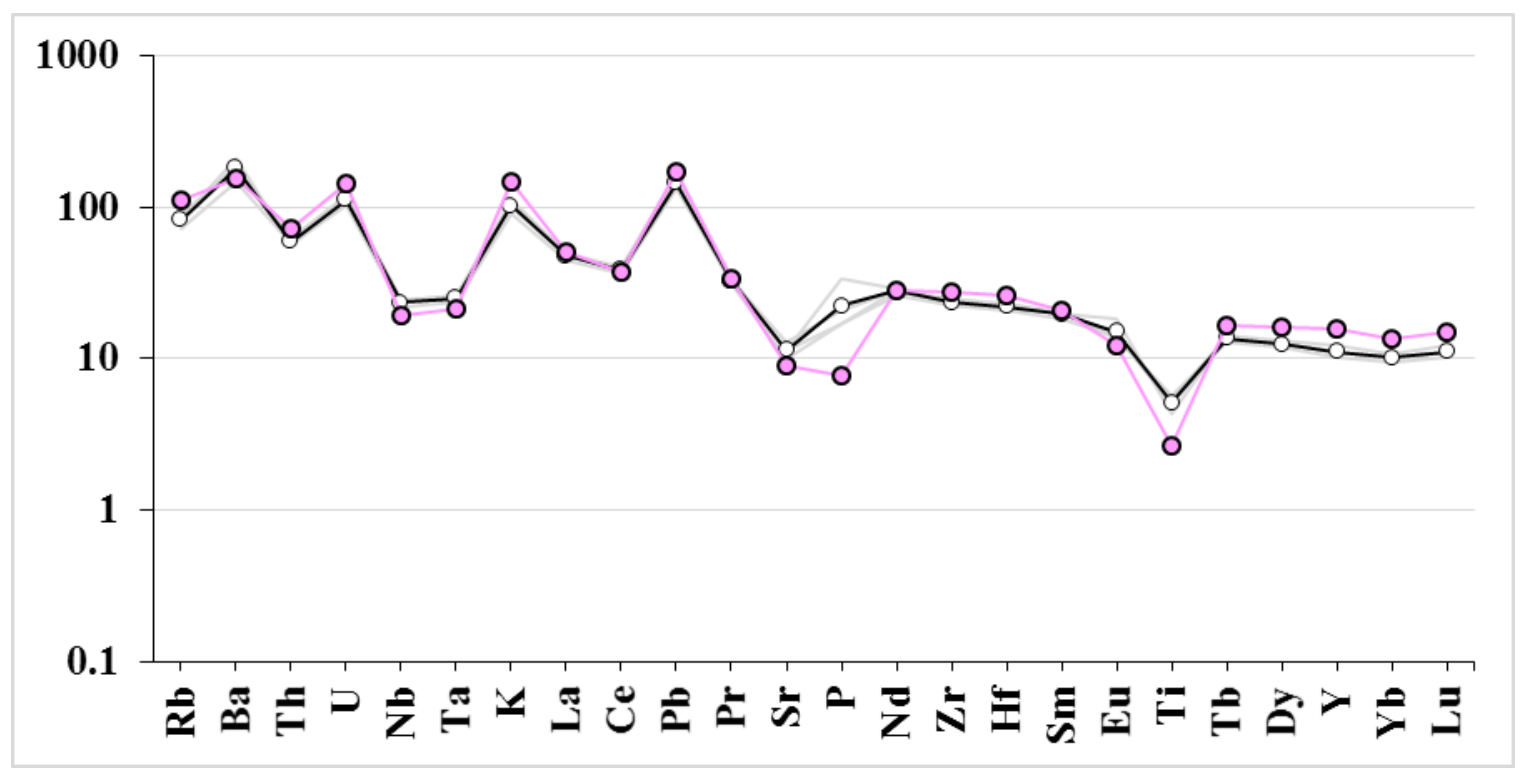

Figure 95: Multi-element diagram of average geochemical group T3 (light pink) in comparison to average of DIT4 (black line w/ black circles) and within group DIT4 samples (grayed). DIT data from Streck et al. (2015). Concentrations normalized to mantle values of Sun and McDonough (1989)

\section{Basalt Units:}

There are three geochemically distinct basalt groups that correspond to the three groups defined by physical characteristics. Basalt group B1 includes sample DM038, which has $\sim 1 \%$ feldspar phenocrysts and is slightly more enriched than B3 samples. Basalt group B2, sample DM255A with 5\% feldspar phenocrysts, has greater enrichment than B1 or B3, except for Y-Lu. Group B3 includes samples DM255B and DM260 ( 15-30\% feldspar phenocrysts), and is the least enriched of the three basalt groups.

Comparison of the three basalt groups to geochemical data for Grande Ronde, Picture Gorge and Imnaha Basalts from Wolff et al. (2008) indicate that basalt B1 and B3 correlate best with Picture Gorge Basalt (Figure 96). Similarities between B1, B3 and the Picture Gorge Basalt include a pronounced enrichment of Ba compared to $\mathrm{Rb}$ and $\mathrm{Th}$, 


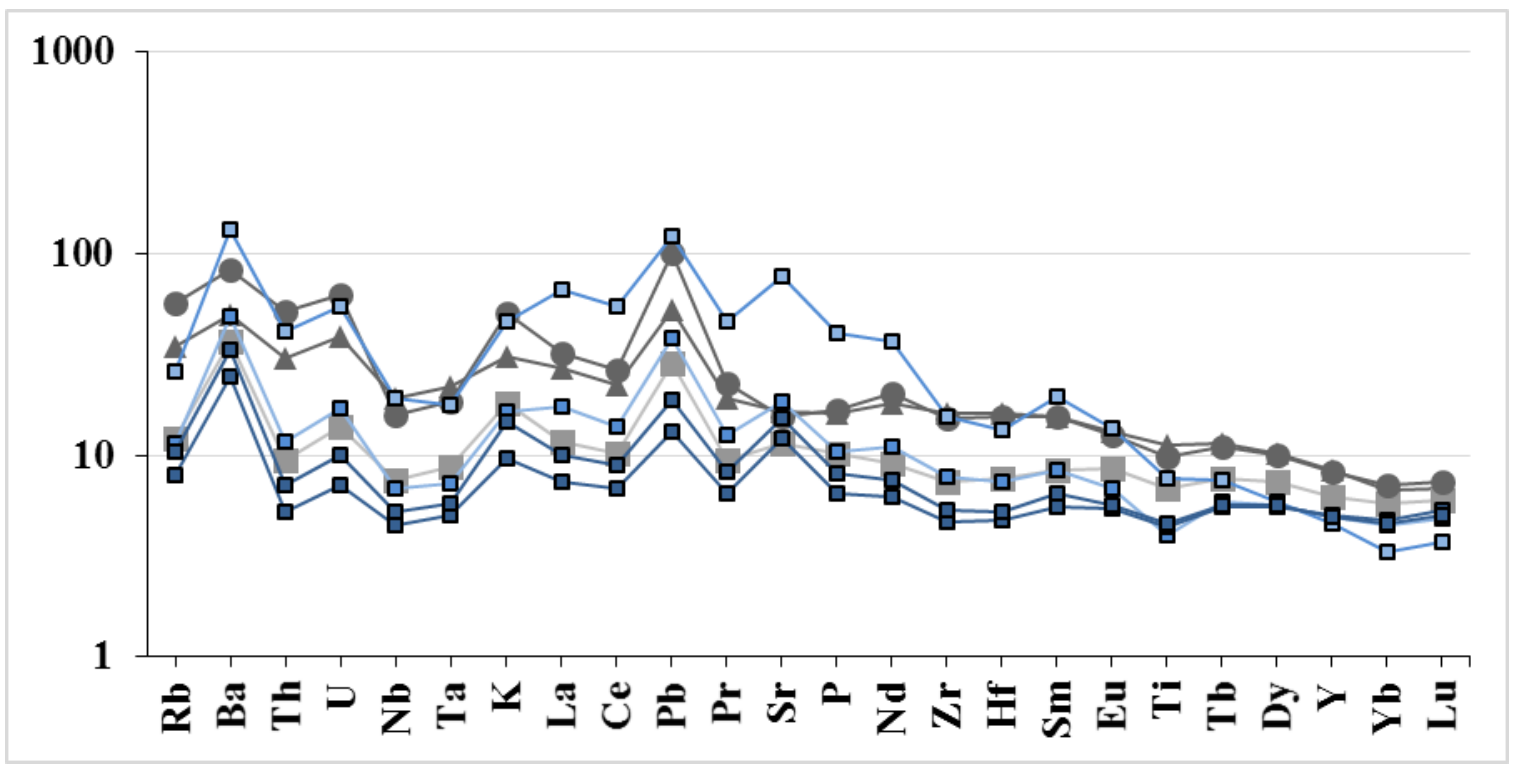

Figure 96: Plot of Ba vs. Ta and multi-element diagram of basalt units B1-B3 in comparison to average of Imnaha basalts (dark gray triangle), Picture Gorge basalts (light gray squares) and Grande Ronde basalts (dark gray circles). B1: dark blue squares. B2: medium blue squares. B3: light blue squares. Point data and calculated average basalt used in multi-element diagram from Wolff et al. (2008)

$\mathrm{Ba} / \mathrm{Nb}$ values greater than 4 (due to $\mathrm{Ba}$ enrichment rather than $\mathrm{Nb}$ depletion such as Grande Ronde Basalt) and less overall enrichment than Imnaha or Grande Ronde Basalt.

Unit B2 appears to be geochemically related to groups B1 and B3 but is from a more evolved and enriched magma. 


\section{Discussion and Conclusions}

The previously work done at the Dooley Mountain rhyolite complex by Gilluly (1937), Whitson (1988) and Evans (1992) left unanswered questions and interpretations in need of revision. The issues we address include:

- Are the geologic descriptions and interpretations of the rocks correct and are the rocks at the Dooley Mountain rhyolite complex predominantly of pyroclastic origin?

- Are the previously determined number of geochemical groups consistent with modern geochemical data?

- Is the Dooley Mountain rhyolite complex contemporaneous with the Columbia River Basalts or,

- Was the Dooley Mountain rhyolite complex emplaced over multiple eruptive periods before, during or after the eruption of the Columbia River Basalts?

\section{Geologic descriptions and interpretations}

Ten of the thirteen major unit divisions described by Evans (1992) include or are described as tuff. Although there are occurrences of tuff units throughout the quadrangle they do not appear to be neither dominant nor widespread units. Of over 100 hand samples (Appendix B-1) collected in the field, 11 samples from only six locations were identified as tuffs. There were however widespread breccias that may have been interpreted as ash-flow tuffs. At best, some of the breccia may be block-and-ash flow tuffs and not basal or top breccias of lava flows. Distinction between these two options 
can be very difficult on small single outcrops. The vast majority of samples were massive or brecciated rhyolite.

\section{Geochemical groups}

Whitson (1988) concluded that there were four main geochemical groups of rhyolites within the Dooley mountain rhyolite. We confirm this assertion with modern XRF and ICP-MS data; however when comparing the distribution of samples within Whitson's groups to distribution there are differences. Whitson's group 1, 2 and 3 roughly correlate with our R3/R4, R1/R2 and R3/R4, respectively, and his group 4 is poorly defined and does not correlate well with our results.

Additionally, we have identified and correlated three rhyolitic tuff units to three distinct eruptive units of the Dinner Creek Tuff and three basalt units, two of which are Picture Gorge Basalt and the third geochemically related. By correlating the results of our geochemical groups with the geologic units previously mapped by Evans (1992) (Figure 97 and Table 12) we are able make revisions (Figure 99 and 100). 


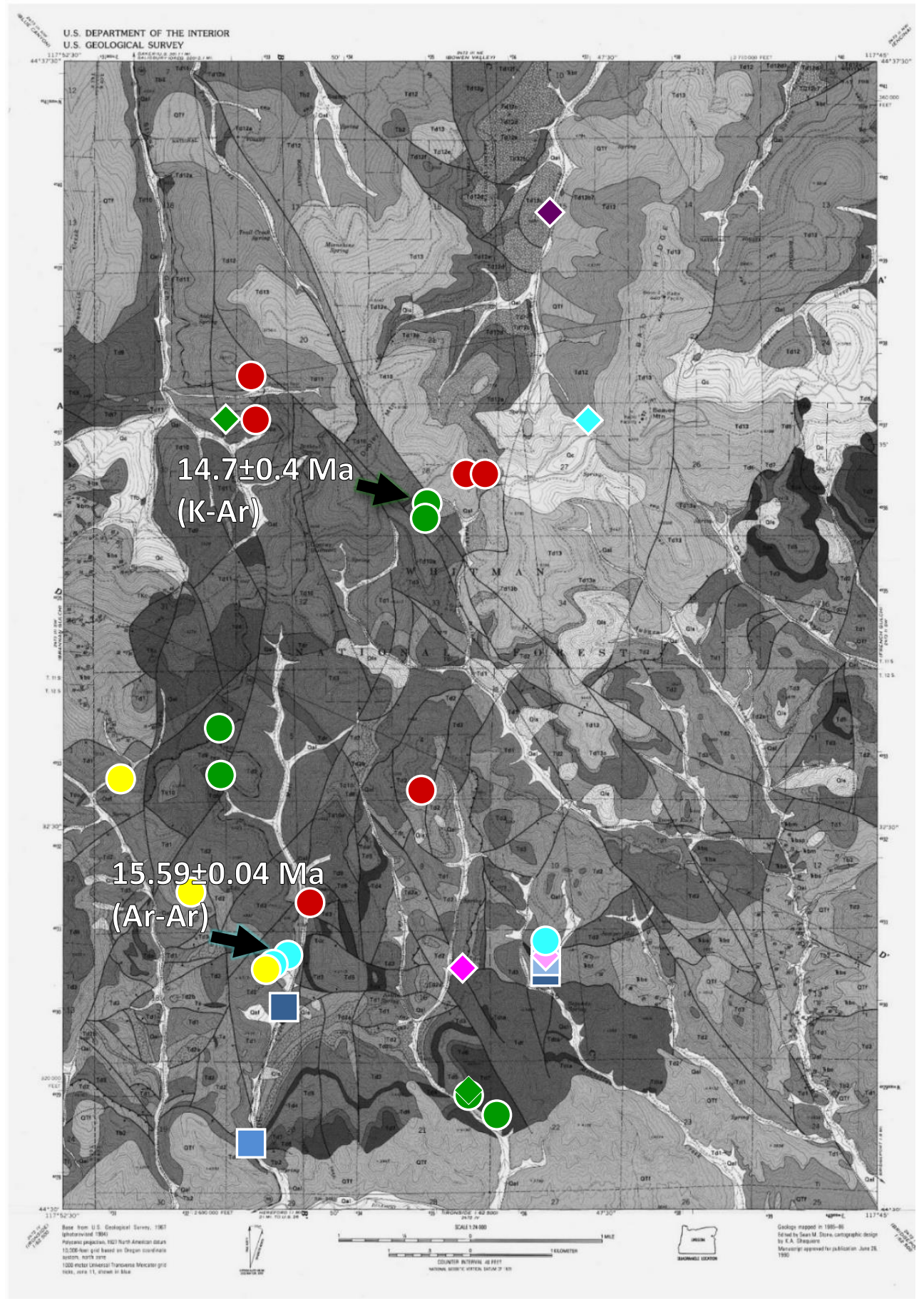

Figure 97: Geologic map showing locations of samples used for geochemical analysis and radiometric age dating. Unit R1: light blue; Unit R2s: yellow; Unit R3s: red; Unit R4: green; Unit T1: magenta; Unit T2: dark pink; Unit T3: light pink; Unit B1: dark blue square; Unit B2: medium blue square; Unit B3: light blue-gray square. Pyroclastic units identified with diamonds. Rhyolite flows and domes indicated with circles. Basalt flows indicated with squares. Map modified from Evans (1992). Ar-Ar age date from Hess (2014). K-Ar age date from Walker et al. (1974). 
Table 12: Correlation of geochemical groups with units mapped by Evans (1992).

\begin{tabular}{|c|c|c|}
\hline Sample Number & Group & $\begin{array}{l}\text { Unit Mapped by } \\
\text { Evans (1992) }\end{array}$ \\
\hline DR4 & 1 & $\mathrm{Td} 3$ \\
\hline EJ-23B & 1 & $\mathrm{Td} 3$ \\
\hline DM247 & 1 & (Td12) \\
\hline DM258 & 1 & $(\mathrm{Td} 1 / \mathrm{Td} 2)$ \\
\hline EJ-23A & 2 & $\mathrm{Td} 2$ \\
\hline DM234 & 2 & $\mathrm{Td} 2$ \\
\hline DM235 & 2 & $\mathrm{Td} 1$ \\
\hline DR2 & 3 & Td11 \\
\hline DM202 & 3 & Td11 \\
\hline DM220 & 3 & $(\mathrm{Td} 2)$ \\
\hline DM240 & 3 & Td13b \\
\hline DM241 & 3 & Td13a \\
\hline DM250 & 3 & $(\mathrm{Td} 2)$ \\
\hline MS-11-22DR & 4 & Unassigned \\
\hline DM223 & 4 & Td10 \\
\hline DM238 & 4 & Tdo \\
\hline DM264 & 4 & Td7 \\
\hline DM265A & 4 & Td6 \\
\hline DM265 & 4 & Td6 \\
\hline DM265B & 4 & Td6 \\
\hline DM273A & 4 & Td9 \\
\hline DM246A & T1 & $(\operatorname{Td} 12 c)$ \\
\hline DM269 & $\mathrm{T} 2$ & $(T d t)$ \\
\hline DM256 & T3 & (Td1) \\
\hline DM260 & B1 & Tb1 \\
\hline DM255B & B1 & Tb1 \\
\hline DM038 & B2 & Tb2 \\
\hline DM255A & B3 & Unassigned \\
\hline
\end{tabular}




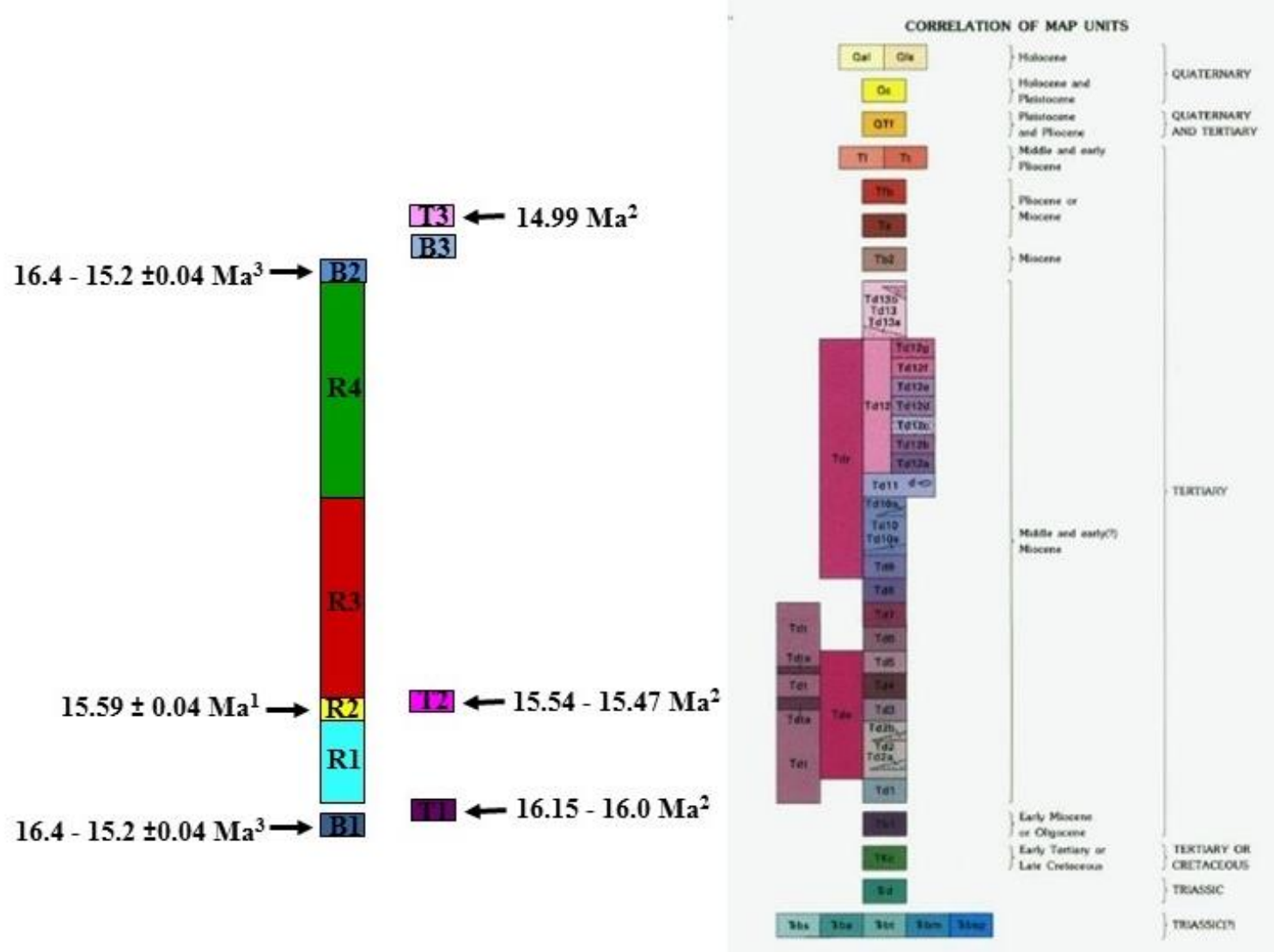

Figure 98: Correlation of geochemical groups with stratigraphy from Evans (1992). Age date sources: 1 Hess (2014); 2 - Streck (2015); 3 - Barry et al. (2013) 


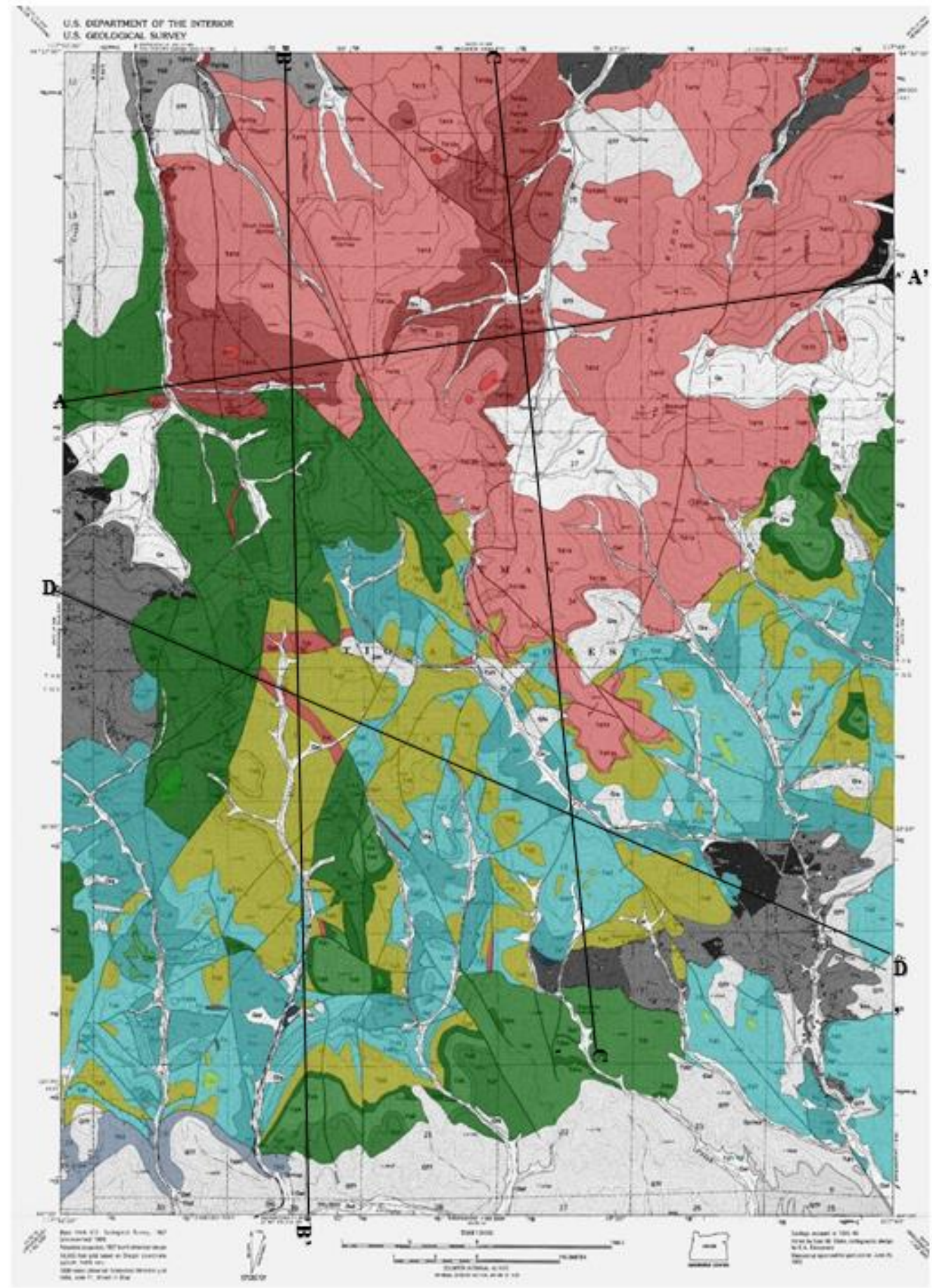

Figure 99: Geologic map showing extent of eruptive units determined by geochemical groups. Rhyolite Unit R1: light blue; Rhyolite unit R2: yellow; Rhyolite unit R3: red; Rhyolite unit R4: green. Basalt unit B1: dark blue; Basalt unit B2: light gray-blue. Tuff units T1-T3 are not shown on the map as there was no correlative unit mapped by Evans (1992). Map modified from Evans (1992). 


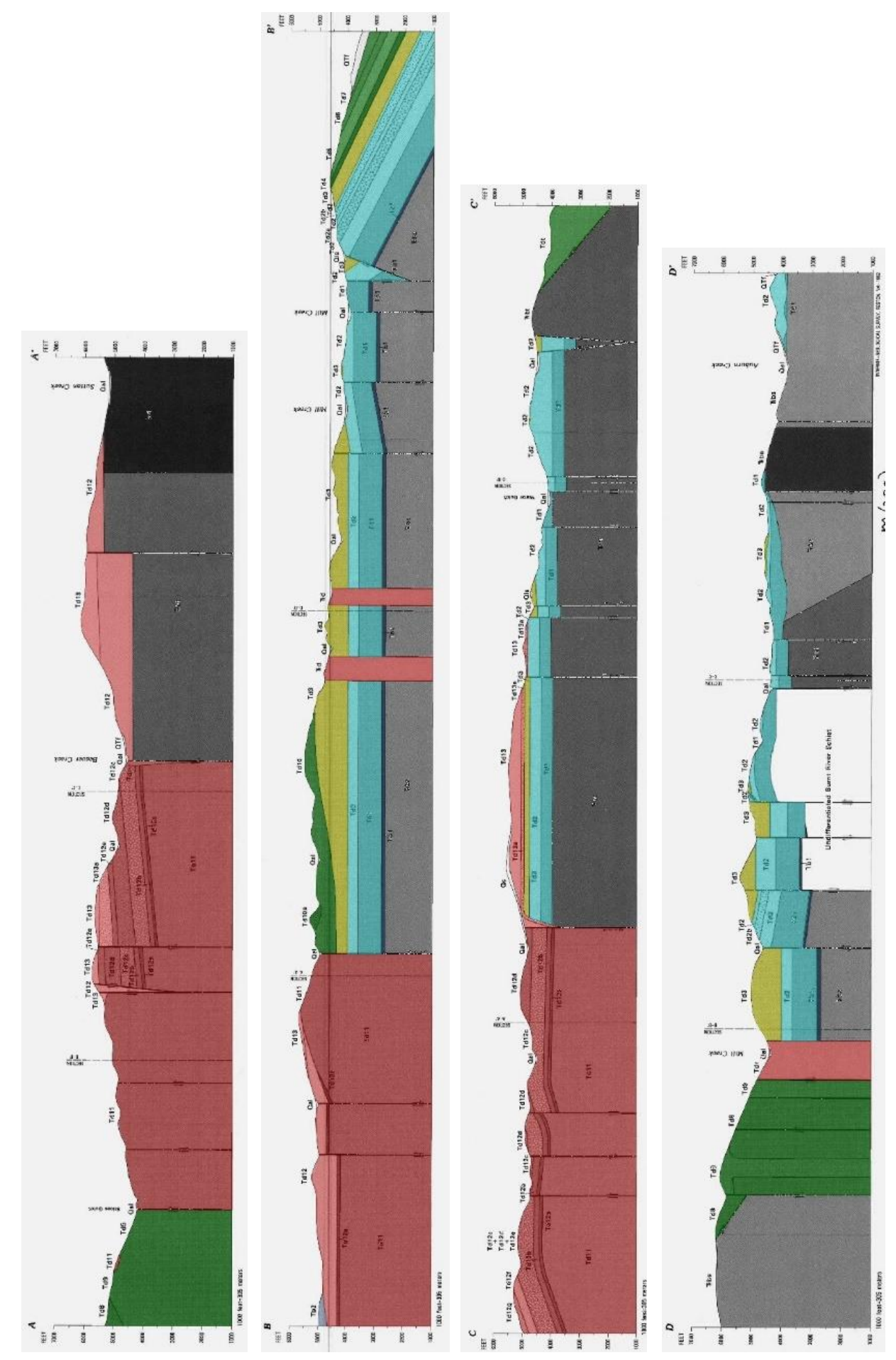

Figure 100: Geologic cross sections with eruptive units determined by geochemical analysis. Rhyolite Unit R1: light blue; Rhyolite unit R2: yellow; Rhyolite unit R3: red; Rhyolite unit R4: green. Basalt unit B1: dark blue. Cross sections modified from Evan (1992). 


\section{Geologic timeline of the Dooley Mountain rhyolite complex}

The Dooley Mountain rhyolite complex consists of multiple eruptive units that were emplaced probably during two distinct periods of activity. Geochemical analysis indicates that there are at least four distinct eruptive units, two from each period of activity, R1 \& R2 being the earlier eruptive units and R3 \& R4 the later ones.

The first eruptive period (units R1 and R2) occurred as early as 16 Ma, post emplacement of the Dinner Creek Tuff unit 1 at 16.15-16.0 Ma (Streck, 2015) and a flow unit of the Picture Gorge Basalt member of the CRBG as early as 16.4 Ma (Barry et al., 2013). One Ar-Ar age date of 15.59 \pm 0.04 Ma from Hess (2014) from the stratigraphically younger unit of eruptive period 1 is consistent with this stratigraphy.

The second eruptive period (units R3 and R4) occurred after emplacement of Dinner Creek Tuff unit 2 (15.54-15.47 Ma) (Streck, 2015). One K-Ar age date from Walker et al. (1974) of $14.7 \pm 0.4$ is not consistent with the presence of at least one additional Picture Gorge Basalt unit overlying R3 in the south which is thought to be at the latest 15.2 $\pm 0.04 \mathrm{Ma}$ (Barry et al., 2013).

The youngest stratigraphic unit identified is Dinner Creek Tuff unit 4 with an age of 14.99 Ma (Streck, 2015). This unit is located in the south of the study area, and in the field, appears to be directly overlying basalt unit B1 and B3 and underlying rhyolite unit R1. The field observed relationship is not congruent with the age dates that have been presented for all other units. The most likely cause of this incongruity is emplacement of Dinner Creek Tuff unit 4 as a valley fill deposit in the eroded rhyolite. The presence of 
basalt B3 boulders alongside B1 in this location can also be attributed to transportation during erosion of the rhyolite.

The age of these eruptive events make the Dooley Mountain rhyolite complex an early eruptive center associated with the Yellowstone hotspot. This complex is the northernmost identified rhyolite center within the region of mid Miocene rhyolite initiation. 


\section{Conclusion}

Mid-Miocene silicic volcanism in eastern Oregon is generally accepted to have initiated as early as 16.7-16.5 Ma near the Oregon-Idaho-Nevada border (e.g. McDermitt volcanic field). Whether or not there was a northward progression from this initiation point, as suggested by Coble and Mahood (2012), or widespread coeval volcanism without south to north progression, as suggested by Streck et al. (2015), is still under debate.

Evidence from this study show that both the Buchanan rhyolite complex and Dooley Mountain rhyolite complex were early (16.6-15.6 Ma) eruptive centers that do not fit the northward progressing model put forth by Coble and Mahood (2012). The Buchanan rhyolite complex eruptive period began from at least $16.13 \pm 0.11 \mathrm{Ma}$ (Hess, 2014) to as old as the Upper Steens $\sim 16.57 \pm 0.04 \mathrm{Ma}$ (Brueseke et al., 2007) and ended by the time the Wildcat Creek ash-flow tuff was emplaced ca. 15.9 \pm 0.2 Hooper et al. (2002). The Dooley Rhyolite complex eruptive period began from at least $15.59 \pm 0.04 \mathrm{Ma}$ Hess (2014) to as old as 16.15-16.00 Ma just after emplacement of DIT 1 (Streck et al., 2015) and lasted until, at the latest, $15.2 \pm 0.04 \mathrm{Ma}$ (Barry et al., 2013) when the Picture Gorge basalt eruptions were winding down.

These data support the model that Streck et al. (2015) present that assert widespread silicic volcanism "popped up" throughout eastern Oregon coeval with main phase CRBG eruptions and are as old the volcanic centers at the southern periphery (e.g. McDermitt volcanic field). 


\section{References}

Barry, T. L., Kelley, S. P., Reidel, S. P., Camp, V. E., Self, S., Jarboe, N. A., and Renne, P. R., 2013. Eruption chronology of the Columbia River Basalt Group: Geological Society of America Special Papers, v. 497, p. 45-66.

Brooks, H.C., McIntyre, J.R., and Walker, G.W., 1976, Geology of the Oregon part of the Baker 1 x 2 degree quadrangle: Oregon Department of Geology and Mineral Industries, Geological Map Series 7, scale 1:250,000.

Brown, D.E., McLean, G.D., and Black, G.L., 1980, Preliminary geology and geothermal resource potential of the northern Harney Basin, Oregon: State of Oregon Department of Geology and Mineral Industries Open-File Report O-80-6, 55 p., 4 sheets.

Brueseke, M.E., Heizler, M.T., Hart, W.K., and Mertzman, S.A., 2007, Distribution and geochronology of Oregon Plateau (USA) flood basalt volcanism: The Steens Basalt revisited: Journal of Volcanology and Geothermal Research, v. 161(3), p. 187-214.

Camp, V.E., Ross, M.E., and Hanson, W.E., 2003, Genesis of flood basalts and Basin and Range volcanic rocks from Steens Mountain to the Malheur River Gorge, Oregon: Geological Society of America Bulletin, v. 115(1), p. 105-128.

Coble, M.A., and Mahood, G.A., 2012, Initial impingement of the Yellowstone plume located by widespread silicic volcanism contemporaneous with Columbia River flood basalts: Geology, v. 4, p. 655-658. 
Cummings, M.L., Evans, J.G., Ferns, M.L., and Lees, K.R., 2000, Stratigraphic and structural evolution of the middle Miocene synvolcanic Oregon-Idaho graben: Geological Society of America Bulletin, v. 112, no. 5, p. 668-682.

Fiebelkorn, R.B., Walker, G.W., MacLeod, N.S., McKee, E.H., and Smith, J.G., 1982, Index to K-Ar age determinations for the State of Oregon: U.S. Geological Survey Open-File Report 82-596, 43p.

Evans, J.G., 1992, Geologic map of the Dooley Mountain 7 1⁄2' quadrangle, Baker County, Oregon: U.S. Geological Survey, Geologic Quadrangle Map GQ-1694, scale 1:24,000.

Gilluly, J., 1937, Geology and mineral resources of the Baker quadrangle, Oregon: U.S. Geological Survey, Bulletin 879, scale 1:125,000.

Greene, R.C., Walker, G.W., and Corcoran, R.E., 1972, Geologic map of the Burns quadrangle: U.S. Geological Survey Miscellaneous Geologic Investigations Map I-680, scale 1:250,000, 1 sheet.

Hess, E.N., 2014, Strontium, Lead, and Oxygen Isotopic Signatures of Mid-Miocene Silicic Volcanism in Eastern Oregon [M.S. thesis]: Portland, Portland State University, $102 \mathrm{p}$.

Hildreth, W., 1981, Gradients in Silicic Magma Chambers: Implications for Lithoshperic Magmatism; Journal of Geophysical Research, v. 86(B11), p. 0153-10192. 
Hooper, P.R., Binger, G.B., and Lees, K.R., 2002, Ages of the Steens and Columbia River flood basalts and their relationship to extension-related calc-alkalic volcanism in eastern Oregon: Geological Society of America Bulletin, v. 114(1), p. 43-50.

Johnson, D.M., Hooper, P.R., and Conrey, R.M., 1999, XRF analysis of rocks and minerals for major and trace elements on a single low dilution Li-tetraborate fused bead: Advances in X-ray Analysis, v. 41, p. 843-867.

Johnson, D. M., Hooper, P. R., \& Conrey, R. M. (1999). XRF analysis of rocks and minerals for major and trace elements on a single low dilution Li-tetraborate fused bead. In Advances in X-ray Analysis, v, 41, p. 843-867 Le Bas, MJ.

McDonough, W.F., and Sun, S.S., 1995, The composition of the Earth: Chemical geology, v. 120(3), p. 223-253.

McKee, E.H., and Walker, G.W., 1976, Potassium-argon ages of late Cenozoic silicic volcanic rocks, southeastern Oregon: Isochron West, v. 15, p. 37-41.

Pierce, K.L, and Morgan, L.A., 2009, Is the track of the Yellowstone hotspot driven by a deep mantle plume? Review of volcanism, faulting and uplift in light of new data: Journal of Volcanology and Geothermal Research, v. 188, 25 p.

Piper, A.M., Robinson, T.W., Park, C.F., and Jessup, L.T., 1939, Geology and groundwater resources of the Harney Basin, Oregon, with a statement on Precipitation and tree growth: U.S. Geological Survey Water-Supply Paper 841. 223 p. 1 sheet. 
Shervais, J.W., and Hanan, B.B., 2008, Lithospheric topography, tilted plumes and the track of the Snake River - Yellowstone hot spot: Tectonics, v. 27(5)

Streck, M. J., Ferns, M. L., and McIntosh, W. 2015. Large, persistent rhyolitic magma reservoirs above Columbia River Basalt storage sites: The Dinner Creek Tuff Eruptive Center, eastern Oregon: Geosphere, v. 11(2), p. 226-235.

Streck, M.J., and Grunder, A.L., 1997, Compositional gradients and gaps in high-silica rhyolites of the Rattlesnake Tuff, Oregon: Journal of Petrology, v. 38(1), p.133163

Streck, M.J., Ferns, M.L., and McIntosh, W.C., 2015, New data on mid-Miocene rhyolite volcanism in eastern Oregon extend early, co-CRBG rhyolite Flare up and constrain storage sites of Grande Ronde Flood Basalts, Abstract V24C-03 presented at 2015 fall meeting, AGU, San Fransisco, Calif. 14-18 Dec.

Sun, S.S., and McDonough, W.F., 1989, Chemical and isotopic systematics of oceanic basalts: implications for mantle composition and processes: Geological Society Special Publication, n. 42, p. 313-345.

Walker, G.W., Dalrymple, G.B., and Lanphere, M.A., 1974, Index to potassium-argon ages of Cenozoic volcanic rocks of Oregon: U.S. Geological Survey Miscellaneous Field Studies Map MF-569, scale 1:1,000,000, 2 sheets

Walker, G.W., 1977, Geologic map of Oregon east of the $121^{\text {st }}$ meridian: U.S. Geological Survey, Miscellaneous Investigations Series Map I-902, scale 1:500,000. 
Walker, G.W., 1979, Revisions to the Cenozoic stratigraphy of Harney Basin, southeastern Oregon: U.S. Geological Survey Bulletin 1475, 41 p.

Whitson, N.W., 1988, Geochemical stratigraphy of the Dooley Rhyolite Breccia and Tertiary basalts in the Dooley Mountain quadrangle, Oregon [M.S. thesis]: Portland, Portland State University, 122 p.

Wolff, J.A., Ramos, F.C., Hart, G.L., Patterson, J.D., and Brandon, A.D., 2008, Columbia River flood basalts from a centralized crustal magmatic system: Nature geoscience, v. 1(3), p. 177-180.

Wright, W.E., Baisan, C., Streck, M., Wright, W.W., and Szejner, P., 2016, Dendrochronology and middle Miocene petrified oak: Modern counterparts and interpretation: Palaeogeography, Palaeoclimatology, Palaeoecology, v. 445, p. 3849. 
Appendix A : Buchanan Rhyolite Complex 


\section{Appendix A-1 : Petrographic Data}

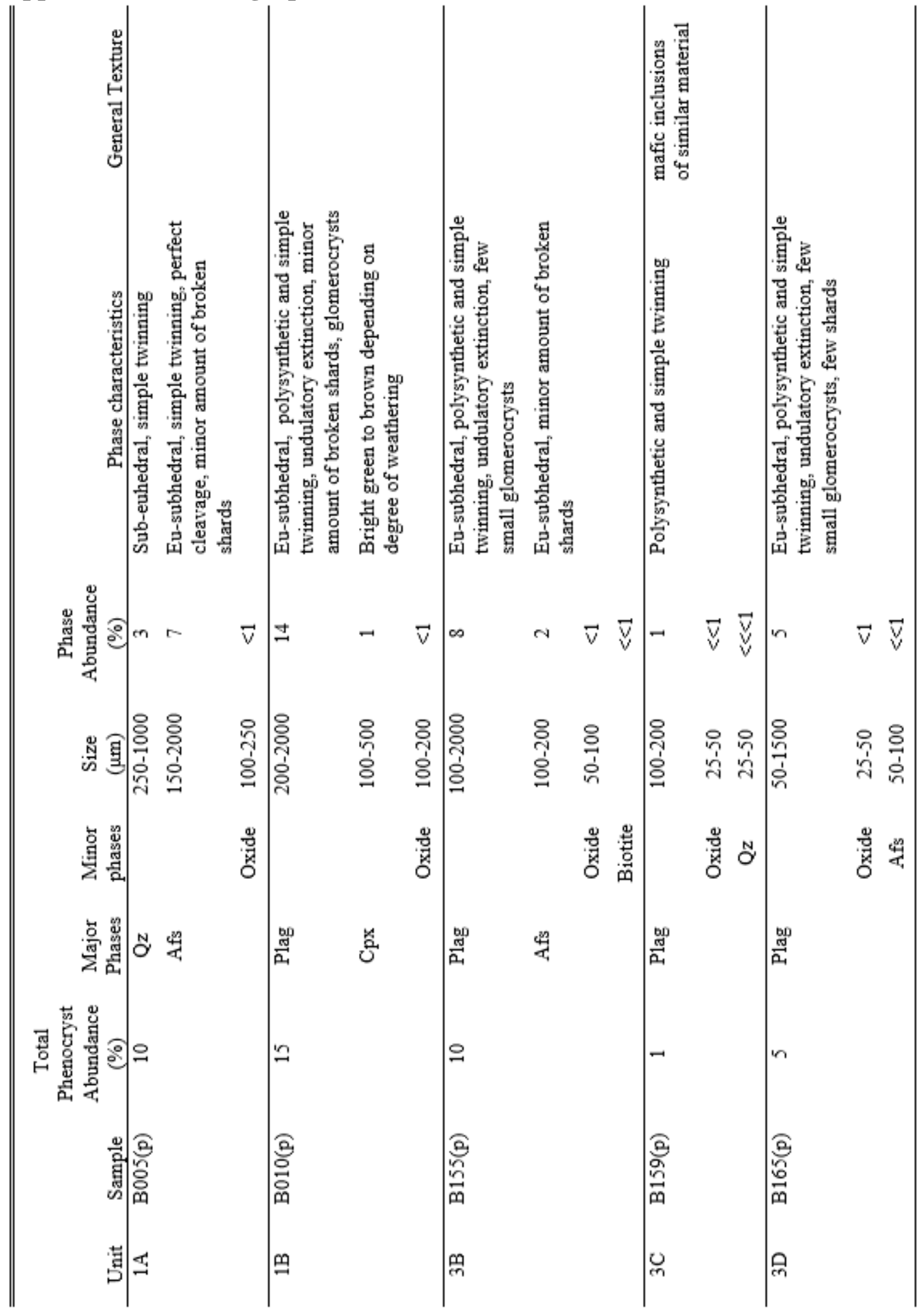




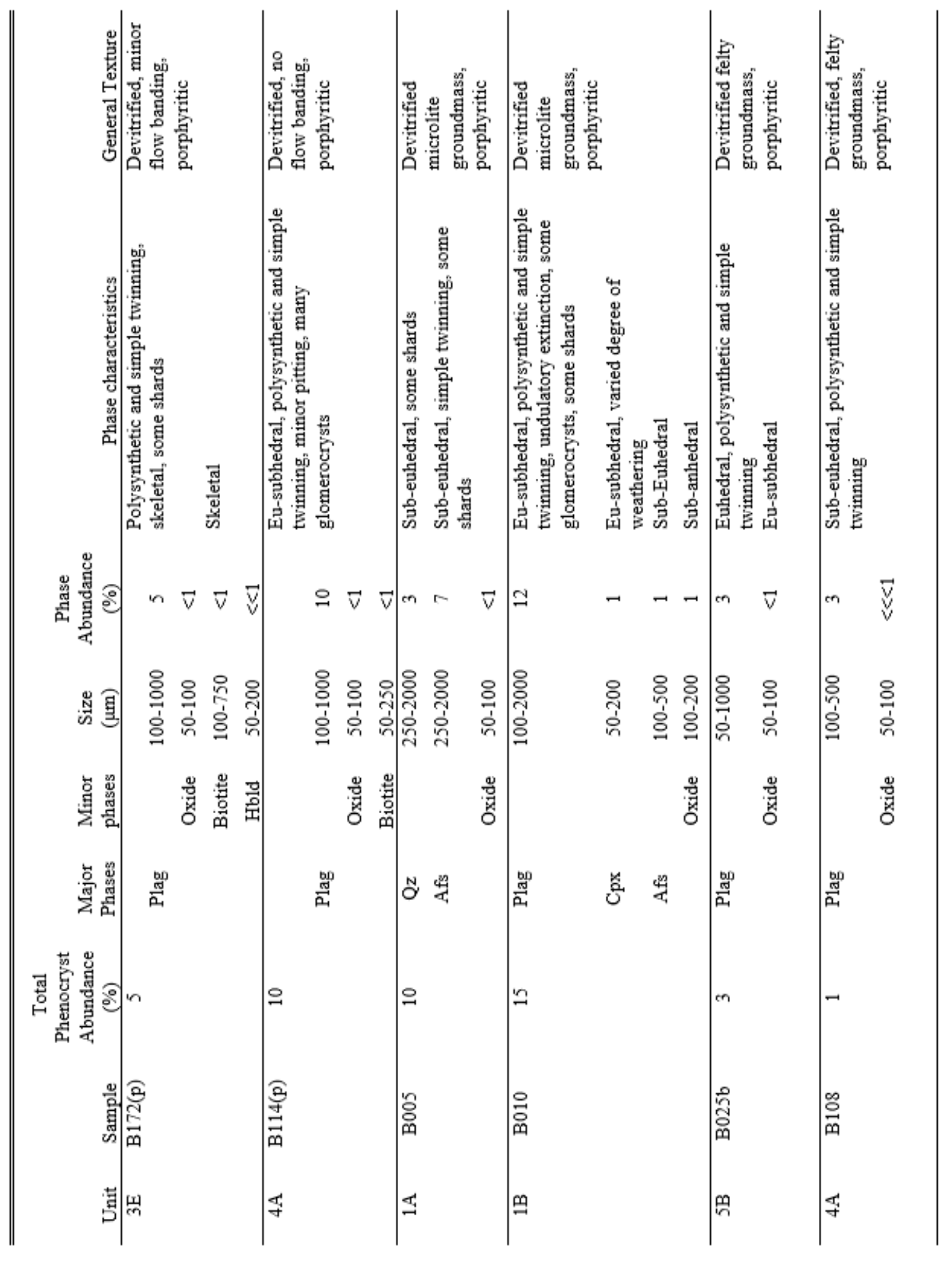




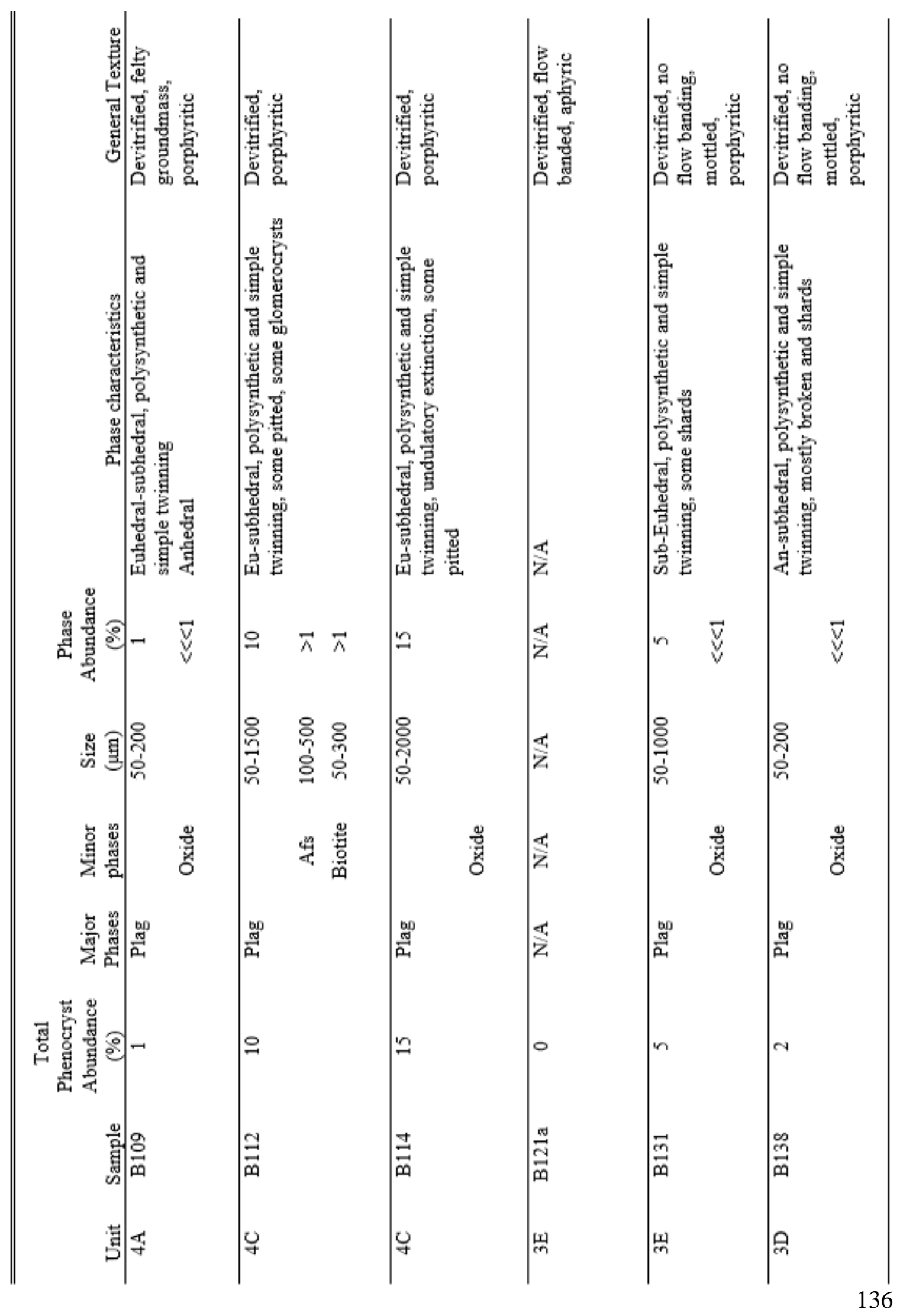




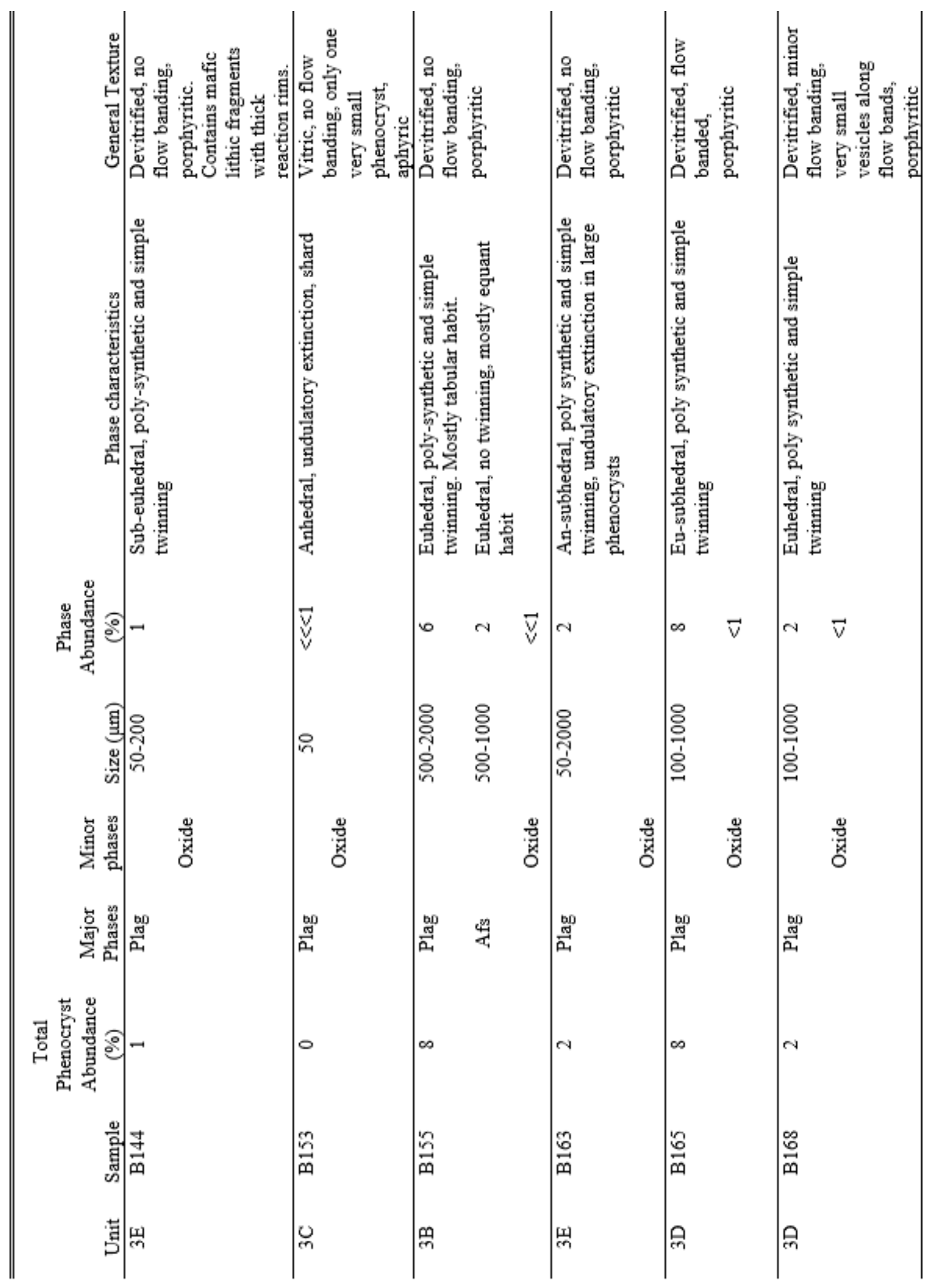




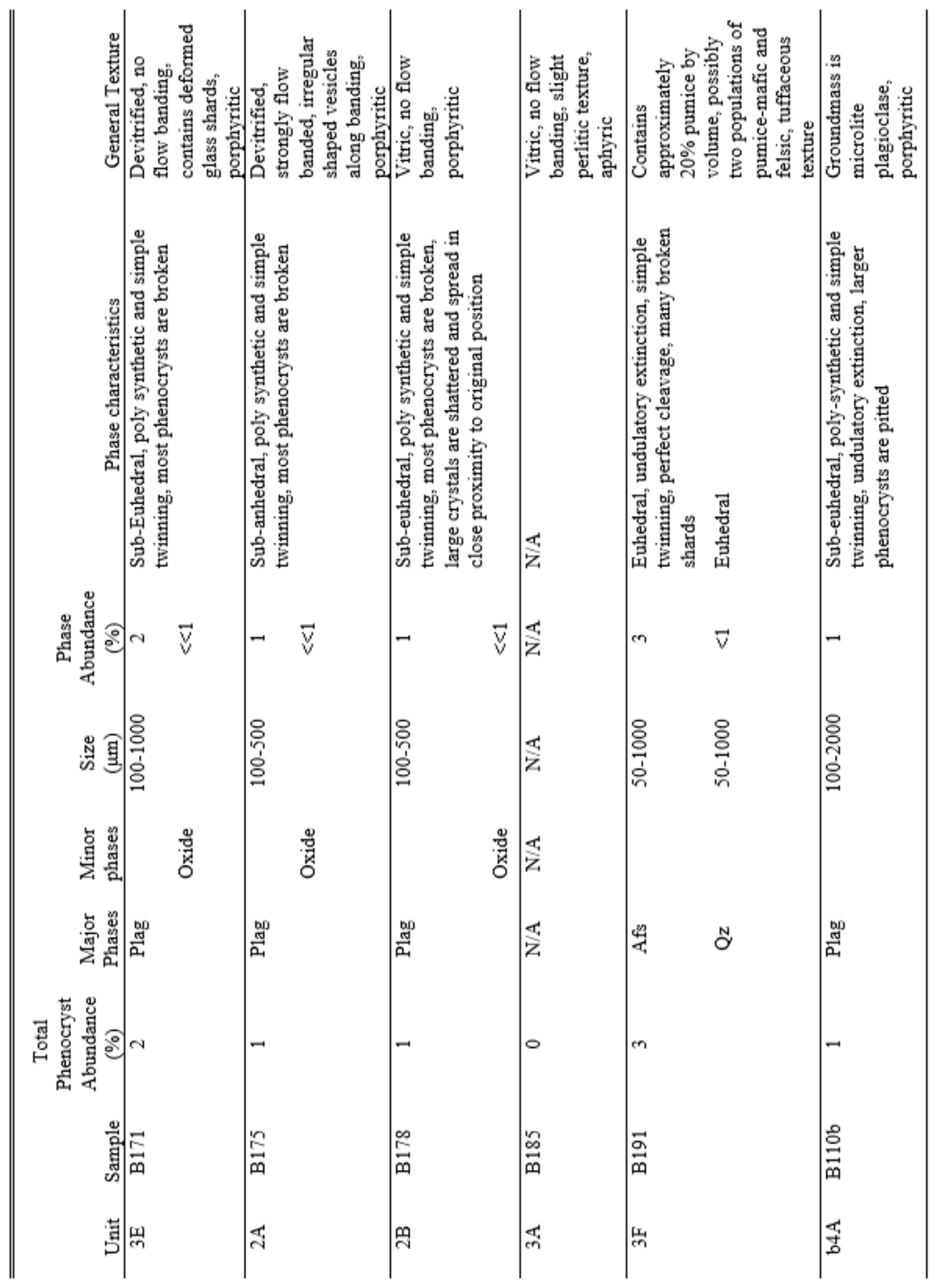




\section{Appendix A-2 : Geochemical Data}

\section{A-2a : XRF results}

Samples with unit designation in parentheses (e.g. Samples ID: B153, Unit (R5))

were not used in the analysis of data but are stratigraphically within the listed unit.

\begin{tabular}{|c|c|c|c|c|c|c|c|c|}
\hline $\begin{array}{l}\text { Sample } \\
\text { ID }\end{array}$ & B001C & B005 & B010 & B013 & B014 & B015 & B022 & $\mathrm{B} 025 \mathrm{~B}$ \\
\hline \multirow[t]{2}{*}{ Unit } & $\mathrm{R} 1$ & $\mathrm{R} 1$ & $\mathrm{R} 3$ & RT & $\mathrm{R} 8$ & $\mathrm{R} 8$ & R3 & R5 \\
\hline & \multicolumn{8}{|c|}{ This Study } \\
\hline \multicolumn{9}{|c|}{ XRF - wt\% (normalized) } \\
\hline $\mathrm{SiO} 2$ & 84.61 & 80.64 & 70.07 & 71.47 & 75.33 & 75.32 & 76.83 & 77.56 \\
\hline $\mathrm{TiO} 2$ & 0.076 & 0.084 & 0.648 & 0.228 & 0.203 & 0.204 & 0.473 & 0.188 \\
\hline $\mathrm{A} 12 \mathrm{O} 3$ & 8.10 & 10.29 & 14.76 & 12.84 & 13.25 & 13.36 & 11.15 & 12.37 \\
\hline $\mathrm{FeO}^{*}$ & 0.67 & 1.02 & 4.17 & 2.79 & 1.47 & 1.44 & 3.51 & 0.82 \\
\hline $\mathrm{MnO}$ & 0.002 & 0.030 & 0.061 & 0.045 & 0.043 & 0.041 & 0.053 & 0.011 \\
\hline $\mathrm{MgO}$ & 0.00 & 0.00 & 0.27 & 1.12 & 0.24 & 0.28 & 0.18 & 0.06 \\
\hline $\mathrm{CaO}$ & 0.04 & 0.06 & 2.31 & 1.90 & 1.17 & 1.22 & 1.56 & 1.02 \\
\hline $\mathrm{Na} 2 \mathrm{O}$ & 1.65 & 3.16 & 3.98 & 2.98 & 3.83 & 3.12 & 3.15 & 3.83 \\
\hline $\mathrm{K} 2 \mathrm{O}$ & 4.83 & 4.71 & 3.53 & 6.60 & 4.43 & 4.99 & 2.94 & 4.10 \\
\hline $\mathrm{P} 2 \mathrm{O} 5$ & 0.011 & 0.009 & 0.179 & 0.041 & 0.035 & 0.031 & 0.142 & 0.033 \\
\hline \multicolumn{9}{|c|}{ XRF - ppm (unnormalized): } \\
\hline $\mathrm{Ni}$ & 0 & 0 & 1 & 2 & 1 & 2 & 1 & 0 \\
\hline $\mathrm{Cr}$ & 3 & 3 & 3 & 3 & 3 & 3 & 2 & 3 \\
\hline $\mathrm{Sc}$ & 1 & 3 & 12 & 4 & 5 & 4 & 10 & 4 \\
\hline $\mathrm{V}$ & 3 & 2 & 23 & 6 & 10 & 12 & 18 & 5 \\
\hline $\mathrm{Ba}$ & 101 & 96 & 1736 & 1312 & 1466 & 1581 & 1091 & 1442 \\
\hline $\mathrm{Rb}$ & 129 & 134 & 51 & 75 & 111 & 108 & 72 & 87 \\
\hline $\mathrm{Sr}$ & 7 & 5 & 256 & 142 & 94 & 95 & 143 & 82 \\
\hline $\mathrm{Zr}$ & 204 & 256 & 252 & 359 & 162 & 156 & 209 & 199 \\
\hline $\mathrm{Y}$ & 40 & 36 & 36 & 70 & 29 & 30 & 38 & 25 \\
\hline $\mathrm{Nb}$ & 12 & 14 & 11 & 20 & 10 & 9 & 10 & 11 \\
\hline $\mathrm{Ga}$ & 12 & 15 & 19 & 21 & 15 & 14 & 14 & 13 \\
\hline $\mathrm{Cu}$ & 7 & 2 & 13 & 4 & 7 & 4 & 9 & 4 \\
\hline $\mathrm{Zn}$ & 19 & 62 & 86 & 130 & 34 & 32 & 74 & 23 \\
\hline $\mathrm{Pb}$ & 38 & 9 & 14 & 15 & 16 & 15 & 12 & 13 \\
\hline $\mathrm{La}$ & 16 & 22 & 26 & 38 & 26 & 26 & 21 & 23 \\
\hline $\mathrm{Ce}$ & 45 & 54 & 59 & 82 & 50 & 48 & 42 & 49 \\
\hline Th & 10 & 11 & 9 & 6 & 12 & 11 & 8 & 8 \\
\hline $\mathrm{Nd}$ & 18 & 25 & 24 & 42 & 21 & 19 & 22 & 19 \\
\hline $\mathrm{U}$ & 4 & 5 & 3 & 2 & 5 & 4 & 3 & 4 \\
\hline
\end{tabular}




\begin{tabular}{|c|c|c|c|c|c|c|c|c|}
\hline $\begin{array}{l}\text { Sample } \\
\text { ID }\end{array}$ & B026 & B108 & B109 & B110A & B110B & B111 & B112 & B116 \\
\hline \multirow[t]{2}{*}{ Unit } & R5 & R6 & R6 & $\mathrm{R} 2$ & Ba1 & $\mathrm{Ba} 2$ & R3 & R6 \\
\hline & \multicolumn{8}{|c|}{ This Study } \\
\hline \multicolumn{9}{|c|}{ XRF - wt\% (normalized) } \\
\hline $\mathrm{SiO} 2$ & 72.31 & 75.34 & 76.36 & 77.02 & 55.92 & 56.68 & 69.01 & 75.77 \\
\hline $\mathrm{TiO} 2$ & 0.376 & 0.200 & 0.182 & 0.123 & 0.731 & 1.130 & 0.588 & 0.187 \\
\hline $\mathrm{Al} 2 \mathrm{O} 3$ & 14.44 & 13.58 & 13.11 & 12.60 & 16.73 & 17.41 & 14.83 & 13.18 \\
\hline $\mathrm{FeO}^{*}$ & 2.29 & 1.39 & 1.23 & 1.04 & 7.40 & 8.13 & 4.10 & 1.50 \\
\hline $\mathrm{MnO}$ & 0.046 & 0.020 & 0.008 & 0.037 & 0.125 & 0.153 & 0.091 & 0.009 \\
\hline $\mathrm{MgO}$ & 0.38 & 0.12 & 0.12 & 0.10 & 6.12 & 3.65 & 0.96 & 0.11 \\
\hline $\mathrm{CaO}$ & 1.75 & 0.84 & 0.83 & 0.74 & 8.86 & 7.27 & 3.18 & 0.90 \\
\hline $\mathrm{Na} 2 \mathrm{O}$ & 3.63 & 3.98 & 3.91 & 3.52 & 2.73 & 3.39 & 3.70 & 3.99 \\
\hline $\mathrm{K} 2 \mathrm{O}$ & 4.71 & 4.51 & 4.22 & 4.81 & 1.26 & 1.69 & 3.36 & 4.33 \\
\hline $\mathrm{P} 2 \mathrm{O} 5$ & 0.076 & 0.016 & 0.016 & 0.011 & 0.135 & 0.493 & 0.175 & 0.016 \\
\hline \multicolumn{9}{|c|}{ XRF - ppm (unnormalized): } \\
\hline $\mathrm{Ni}$ & 1 & 4 & 1 & 3 & 117 & 41 & 5 & 2 \\
\hline $\mathrm{Cr}$ & 2 & 6 & 5 & 4 & 203 & 57 & 4 & 3 \\
\hline $\mathrm{Sc}$ & 6 & 5 & 5 & 4 & 29 & 21 & 10 & 4 \\
\hline V & 22 & 7 & 14 & 3 & 172 & 177 & 56 & 11 \\
\hline $\mathrm{Ba}$ & 1489 & 1537 & 1389 & 1071 & 584 & 1440 & 1297 & 1502 \\
\hline $\mathrm{Rb}$ & 81 & 100 & 91 & 128 & 26 & 28 & 78 & 97 \\
\hline $\mathrm{Sr}$ & 162 & 86 & 77 & 54 & 231 & 546 & 239 & 86 \\
\hline $\mathrm{Zr}$ & 285 & 208 & 188 & 121 & 102 & 135 & 208 & 207 \\
\hline $\mathrm{Y}$ & 31 & 21 & 15 & 30 & 24 & 26 & 33 & 25 \\
\hline $\mathrm{Nb}$ & 12 & 11 & 10 & 11 & 5 & 8 & 10 & 11 \\
\hline $\mathrm{Ga}$ & 15 & 14 & 14 & 14 & 16 & 18 & 15 & 14 \\
\hline $\mathrm{Cu}$ & 7 & 5 & 4 & 6 & 78 & 36 & 17 & 4 \\
\hline $\mathrm{Zn}$ & 40 & 31 & 25 & 27 & 59 & 83 & 54 & 32 \\
\hline $\mathrm{Pb}$ & 15 & 16 & 14 & 18 & 4 & 6 & 12 & 15 \\
\hline $\mathrm{La}$ & 27 & 23 & 17 & 27 & 12 & 21 & 25 & 26 \\
\hline $\mathrm{Ce}$ & 49 & 45 & 29 & 53 & 25 & 42 & 48 & 50 \\
\hline Th & 7 & 9 & 8 & 12 & 2 & 2 & 7 & 9 \\
\hline $\mathrm{Nd}$ & 21 & 19 & 11 & 21 & 14 & 22 & 21 & 21 \\
\hline $\mathrm{U}$ & 2 & 4 & 2 & 6 & 2 & 1 & 3 & 4 \\
\hline
\end{tabular}




\begin{tabular}{|c|c|c|c|c|c|c|c|c|}
\hline $\begin{array}{l}\text { Sample } \\
\text { ID }\end{array}$ & B121A & B121B & B126 & B129 & B138 & B144 & B146 & B147 \\
\hline \multirow[t]{2}{*}{ Unit } & $\mathrm{R} 8$ & $\mathrm{R} 8$ & RT & $\mathrm{R} 8$ & R6 & $\mathrm{R} 8$ & $\mathrm{R} 5$ & $\mathrm{R} 2$ \\
\hline & \multicolumn{8}{|c|}{ This Study } \\
\hline \multicolumn{9}{|c|}{ XRF - wt\% (normalized) } \\
\hline $\mathrm{SiO} 2$ & 76.16 & 75.71 & 72.64 & 75.63 & 76.30 & 75.81 & 74.53 & 77.04 \\
\hline $\mathrm{TiO} 2$ & 0.198 & 0.190 & 0.477 & 0.198 & 0.178 & 0.327 & 0.280 & 0.122 \\
\hline $\mathrm{Al} 2 \mathrm{O} 3$ & 13.18 & 13.17 & 13.25 & 13.30 & 13.09 & 12.61 & 13.07 & 12.57 \\
\hline $\mathrm{FeO}^{*}$ & 1.00 & 1.33 & 4.02 & 1.37 & 0.69 & 2.08 & 2.50 & 1.01 \\
\hline $\mathrm{MnO}$ & 0.012 & 0.040 & 0.022 & 0.040 & 0.012 & 0.031 & 0.023 & 0.034 \\
\hline $\mathrm{MgO}$ & 0.10 & 0.20 & 0.34 & 0.22 & 0.18 & 0.22 & 0.29 & 0.11 \\
\hline $\mathrm{CaO}$ & 1.07 & 1.06 & 0.74 & 1.10 & 1.09 & 1.78 & 1.46 & 0.74 \\
\hline $\mathrm{Na} 2 \mathrm{O}$ & 3.65 & 3.78 & 4.76 & 3.23 & 3.93 & 3.31 & 3.48 & 3.53 \\
\hline $\mathrm{K} 2 \mathrm{O}$ & 4.60 & 4.49 & 3.60 & 4.89 & 4.51 & 3.76 & 4.31 & 4.82 \\
\hline $\mathrm{P} 2 \mathrm{O} 5$ & 0.032 & 0.023 & 0.144 & 0.025 & 0.018 & 0.072 & 0.054 & 0.012 \\
\hline \multicolumn{9}{|c|}{ XRF - ppm (unnormalized): } \\
\hline $\mathrm{Ni}$ & 3 & 2 & 4 & 2 & 2 & 14 & 5 & 2 \\
\hline $\mathrm{Cr}$ & 5 & 3 & 4 & 3 & 3 & 16 & 10 & 4 \\
\hline $\mathrm{Sc}$ & 5 & 4 & 7 & 3 & 5 & 7 & 6 & 3 \\
\hline V & 10 & 8 & 26 & 8 & 8 & 29 & 25 & 4 \\
\hline $\mathrm{Ba}$ & 1433 & 1445 & 1531 & 1375 & 1511 & 1356 & 1333 & 1095 \\
\hline $\mathrm{Rb}$ & 117 & 118 & 63 & 111 & 102 & 91 & 120 & 128 \\
\hline $\mathrm{Sr}$ & 91 & 89 & 108 & 87 & 85 & 147 & 112 & 55 \\
\hline $\mathrm{Zr}$ & 155 & 153 & 363 & 147 & 190 & 140 & 149 & 123 \\
\hline $\mathrm{Y}$ & 27 & 29 & 66 & 27 & 24 & 27 & 27 & 30 \\
\hline $\mathrm{Nb}$ & 10 & 10 & 22 & 9 & 10 & 8 & 9 & 11 \\
\hline $\mathrm{Ga}$ & 13 & 14 & 21 & 13 & 15 & 14 & 14 & 14 \\
\hline $\mathrm{Cu}$ & 8 & 5 & 3 & 4 & 3 & 12 & 6 & 4 \\
\hline $\mathrm{Zn}$ & 23 & 29 & 138 & 28 & 17 & 30 & 28 & 27 \\
\hline $\mathrm{Pb}$ & 16 & 16 & 14 & 14 & 17 & 11 & 13 & 17 \\
\hline $\mathrm{La}$ & 24 & 26 & 56 & 26 & 25 & 20 & 22 & 25 \\
\hline $\mathrm{Ce}$ & 47 & 48 & 89 & 42 & 47 & 37 & 42 & 51 \\
\hline Th & 11 & 10 & 7 & 10 & 9 & 9 & 10 & 13 \\
\hline $\mathrm{Nd}$ & 20 & 20 & 50 & 16 & 18 & 17 & 20 & 19 \\
\hline $\mathrm{U}$ & 4 & 7 & 4 & 5 & 3 & 4 & 6 & 5 \\
\hline
\end{tabular}




\begin{tabular}{|c|c|c|c|c|c|c|c|c|}
\hline $\begin{array}{l}\text { Sample } \\
\text { ID }\end{array}$ & B148 & B153 & B155 & B156 & B158 & B159 & B160 & B161 \\
\hline \multirow[t]{2}{*}{ Unit } & $\mathrm{R} 2$ & (R5) & $\mathrm{R} 4$ & $\mathrm{R} 4$ & R4 & R5 & $\mathrm{R} 5$ & R5 \\
\hline & \multicolumn{8}{|c|}{ This Study } \\
\hline \multicolumn{9}{|c|}{ XRF - wt \% (normalized) } \\
\hline $\mathrm{SiO} 2$ & 82.03 & 83.98 & 78.22 & 73.19 & 76.65 & 71.16 & 71.37 & 77.57 \\
\hline $\mathrm{TiO} 2$ & 0.150 & 0.152 & 0.229 & 0.303 & 0.252 & 0.489 & 0.442 & 0.213 \\
\hline $\mathrm{Al} 2 \mathrm{O} 3$ & 9.71 & 9.90 & 11.76 & 13.63 & 12.55 & 14.33 & 14.03 & 12.19 \\
\hline $\mathrm{FeO}^{*}$ & 0.91 & 0.25 & 1.17 & 2.57 & 1.39 & 3.45 & 3.02 & 1.15 \\
\hline $\mathrm{MnO}$ & 0.006 & 0.010 & 0.011 & 0.027 & 0.016 & 0.031 & 0.079 & 0.014 \\
\hline $\mathrm{MgO}$ & 0.05 & 0.86 & 0.02 & 0.18 & 0.02 & 0.40 & 0.98 & 0.14 \\
\hline $\mathrm{CaO}$ & 1.01 & 2.66 & 0.78 & 0.94 & 0.81 & 2.37 & 2.48 & 1.18 \\
\hline $\mathrm{Na} 2 \mathrm{O}$ & 2.58 & 0.17 & 3.30 & 3.90 & 3.67 & 3.55 & 3.57 & 3.28 \\
\hline $\mathrm{K} 2 \mathrm{O}$ & 3.53 & 2.01 & 4.48 & 5.22 & 4.61 & 4.12 & 3.92 & 4.22 \\
\hline $\mathrm{P} 2 \mathrm{O} 5$ & 0.028 & 0.006 & 0.026 & 0.048 & 0.036 & 0.115 & 0.099 & 0.039 \\
\hline \multicolumn{9}{|c|}{ XRF - ppm (unnormalized): } \\
\hline $\mathrm{Ni}$ & 0 & 3 & 3 & 4 & 3 & 26 & 24 & 3 \\
\hline $\mathrm{Cr}$ & 4 & 4 & 7 & 11 & 3 & 28 & 23 & 5 \\
\hline $\mathrm{Sc}$ & 3 & 3 & 5 & 7 & 6 & 11 & 10 & 5 \\
\hline V & 9 & 5 & 11 & 14 & 7 & 69 & 56 & 15 \\
\hline $\mathrm{Ba}$ & 1071 & 1879 & 1318 & 1465 & 1444 & 1224 & 1252 & 1313 \\
\hline $\mathrm{Rb}$ & 87 & 73 & 101 & 147 & 126 & 126 & 99 & 109 \\
\hline $\mathrm{Sr}$ & 77 & 444 & 69 & 75 & 74 & 159 & 154 & 99 \\
\hline $\mathrm{Zr}$ & 118 & 107 & 266 & 309 & 296 & 148 & 149 & 146 \\
\hline $\mathrm{Y}$ & 18 & 13 & 32 & 33 & 27 & 28 & 24 & 25 \\
\hline $\mathrm{Nb}$ & 7 & 6 & 11 & 13 & 13 & 9 & 9 & 8 \\
\hline $\mathrm{Ga}$ & 11 & 7 & 13 & 15 & 15 & 15 & 14 & 13 \\
\hline $\mathrm{Cu}$ & 5 & 1 & 7 & 9 & 8 & 21 & 12 & 9 \\
\hline $\mathrm{Zn}$ & 13 & 10 & 21 & 37 & 29 & 52 & 39 & 20 \\
\hline $\mathrm{Pb}$ & 11 & 7 & 19 & 12 & 13 & 13 & 12 & 12 \\
\hline $\mathrm{La}$ & 16 & 20 & 29 & 28 & 21 & 23 & 22 & 23 \\
\hline $\mathrm{Ce}$ & 35 & 29 & 45 & 53 & 45 & 41 & 39 & 42 \\
\hline Th & 8 & 7 & 11 & 12 & 10 & 8 & 9 & 10 \\
\hline $\mathrm{Nd}$ & 15 & 15 & 24 & 28 & 20 & 17 & 18 & 18 \\
\hline $\mathrm{U}$ & 4 & 1 & 5 & 5 & 4 & 3 & 4 & 3 \\
\hline
\end{tabular}




\begin{tabular}{|c|c|c|c|c|c|c|c|c|}
\hline $\begin{array}{l}\text { Sample } \\
\text { ID }\end{array}$ & B162 & B163 & B165 & B168 & B171 & B175 & B178 & $\mathrm{B} 185$ \\
\hline \multirow[t]{2}{*}{ Unit } & R6 & R6 & (R6) & (R6) & R6 & R6 & $\mathrm{R} 7$ & $\mathrm{R} 2$ \\
\hline & \multicolumn{8}{|c|}{ This Study } \\
\hline \multicolumn{9}{|c|}{ XRF - wt\% (normalized) } \\
\hline $\mathrm{SiO} 2$ & 76.26 & 75.82 & 72.30 & 83.79 & 76.89 & 76.73 & 86.86 & 75.73 \\
\hline $\mathrm{TiO} 2$ & 0.178 & 0.183 & 0.538 & 0.364 & 0.180 & 0.214 & 0.129 & 0.113 \\
\hline $\mathrm{A} 12 \mathrm{O} 3$ & 13.12 & 13.27 & 14.82 & 9.49 & 12.83 & 12.64 & 7.80 & 12.62 \\
\hline $\mathrm{FeO} *$ & 1.16 & 1.22 & 2.22 & 0.81 & 0.99 & 1.02 & 0.61 & 0.99 \\
\hline $\mathrm{MnO}$ & 0.011 & 0.015 & 0.023 & 0.008 & 0.015 & 0.027 & 0.011 & 0.043 \\
\hline $\mathrm{MgO}$ & 0.06 & 0.09 & 0.11 & 0.46 & 0.06 & 0.06 & 0.59 & 0.31 \\
\hline $\mathrm{CaO}$ & 0.84 & 0.89 & 1.66 & 1.78 & 0.90 & 0.71 & 1.13 & 2.75 \\
\hline $\mathrm{Na} 2 \mathrm{O}$ & 3.88 & 3.94 & 4.47 & 0.46 & 3.90 & 3.54 & 0.55 & 2.29 \\
\hline $\mathrm{K} 2 \mathrm{O}$ & 4.47 & 4.56 & 3.75 & 2.81 & 4.21 & 5.03 & 2.30 & 5.14 \\
\hline $\mathrm{P} 2 \mathrm{O} 5$ & 0.024 & 0.022 & 0.094 & 0.027 & 0.019 & 0.025 & 0.016 & 0.017 \\
\hline \multicolumn{9}{|c|}{ XRF - ppm (unnormalized): } \\
\hline $\mathrm{Ni}$ & 2 & 2 & 3 & 1 & 3 & 3 & 2 & 2 \\
\hline $\mathrm{Cr}$ & 3 & 3 & 2 & 2 & 4 & 4 & 4 & 2 \\
\hline $\mathrm{Sc}$ & 4 & 5 & 10 & 5 & 6 & 8 & 5 & 3 \\
\hline V & 9 & 10 & 13 & 7 & 7 & 6 & 7 & 3 \\
\hline $\mathrm{Ba}$ & 1538 & 1512 & 1437 & 3735 & 1467 & 1403 & 1668 & 1034 \\
\hline $\mathrm{Rb}$ & 102 & 103 & 79 & 48 & 94 & 130 & 67 & 112 \\
\hline $\mathrm{Sr}$ & 83 & 88 & 182 & 620 & 89 & 57 & 193 & 188 \\
\hline $\mathrm{Zr}$ & 192 & 194 & 256 & 161 & 191 & 234 & 168 & 112 \\
\hline $\mathrm{Y}$ & 28 & 33 & 39 & 19 & 31 & 56 & 28 & 29 \\
\hline $\mathrm{Nb}$ & 12 & 11 & 14 & 9 & 10 & 11 & 6 & 10 \\
\hline $\mathrm{Ga}$ & 14 & 15 & 17 & 10 & 14 & 15 & 10 & 13 \\
\hline $\mathrm{Cu}$ & 5 & 5 & 6 & 1 & 3 & 5 & 1 & 5 \\
\hline $\mathrm{Zn}$ & 24 & 32 & 102 & 15 & 18 & 49 & 33 & 25 \\
\hline $\mathrm{Pb}$ & 15 & 15 & 13 & 5 & 17 & 14 & 5 & 15 \\
\hline $\mathrm{La}$ & 29 & 28 & 32 & 17 & 29 & 34 & 19 & 28 \\
\hline $\mathrm{Ce}$ & 51 & 50 & 56 & 29 & 44 & 53 & 35 & 44 \\
\hline $\mathrm{Th}$ & 10 & 9 & 8 & 5 & 9 & 10 & 5 & 12 \\
\hline $\mathrm{Nd}$ & 25 & 20 & 28 & 13 & 22 & 36 & 17 & 19 \\
\hline $\mathrm{U}$ & 3 & 3 & 4 & 2 & 3 & 5 & 0 & 4 \\
\hline
\end{tabular}




\begin{tabular}{|c|c|c|c|c|c|c|c|}
\hline $\begin{array}{l}\text { Sample } \\
\text { ID }\end{array}$ & B191 & B352 & B354 & B355 & B356 & EJ-03 & EJ-04 \\
\hline \multirow[t]{2}{*}{ Unit } & RT & R6 & R7 & R6 & Ba1 & $\mathrm{R} 1$ & R6 \\
\hline & \multicolumn{4}{|c|}{ This Study } & & \multicolumn{2}{|c|}{ Hess, 2014} \\
\hline \multicolumn{8}{|c|}{ XRF - wt\% (normalized) } \\
\hline $\mathrm{SiO} 2$ & 68.82 & 75.53 & 81.16 & 75.50 & 57.16 & 78.81 & 84.35 \\
\hline $\mathrm{TiO} 2$ & 0.984 & 0.184 & 0.246 & 0.234 & 1.098 & 0.089 & 0.102 \\
\hline $\mathrm{Al} 2 \mathrm{O} 3$ & 14.19 & 13.42 & 11.04 & 13.38 & 16.61 & 11.22 & 8.20 \\
\hline $\mathrm{FeO}^{*}$ & 4.64 & 1.39 & 1.11 & 1.52 & 8.36 & 0.80 & 1.02 \\
\hline $\mathrm{MnO}$ & 0.110 & 0.03 & 0.05 & 0.07 & 0.09 & 0.019 & 0.013 \\
\hline $\mathrm{MgO}$ & 0.42 & 0.12 & 0.62 & 0.16 & 4.65 & 0.00 & 0.00 \\
\hline $\mathrm{CaO}$ & 2.20 & 0.92 & 2.59 & 0.83 & 7.53 & 0.05 & 0.11 \\
\hline $\mathrm{Na} 2 \mathrm{O}$ & 4.56 & 3.40 & 0.48 & 3.19 & 2.95 & 2.36 & 1.92 \\
\hline $\mathrm{K} 2 \mathrm{O}$ & 3.55 & 4.97 & 2.68 & 5.09 & 1.34 & 6.65 & 4.25 \\
\hline $\mathrm{P} 2 \mathrm{O} 5$ & 0.531 & 0.027 & 0.012 & 0.030 & 0.207 & 0.009 & 0.035 \\
\hline \multicolumn{8}{|c|}{ XRF - ppm (unnormalized): } \\
\hline $\mathrm{Ni}$ & 4 & 1 & 2 & 2 & 86 & 2 & 1 \\
\hline $\mathrm{Cr}$ & 2 & 2 & 4 & 2 & 145 & 4 & 3 \\
\hline $\mathrm{Sc}$ & 14 & 5 & 8 & 6 & 26 & 4 & 5 \\
\hline V & 54 & 6 & 7 & 6 & 188 & 6 & 3 \\
\hline $\mathrm{Ba}$ & 1314 & 1526 & 981 & 1420 & 729 & 149 & 611 \\
\hline $\mathrm{Rb}$ & 57 & 105 & 45 & 216 & 14 & 174 & 97 \\
\hline $\mathrm{Sr}$ & 216 & 88 & 222 & 60 & 270 & 6 & 21 \\
\hline $\mathrm{Zr}$ & 302 & 191 & 240 & 239 & 121 & 272 & 204 \\
\hline $\mathrm{Y}$ & 55 & 31 & 16 & 44 & 25 & 36 & 39 \\
\hline $\mathrm{Nb}$ & 19 & 11 & 11 & 12 & 6 & 16 & 11 \\
\hline $\mathrm{Ga}$ & 21 & 14 & 10 & 15 & 16 & 15 & 10 \\
\hline $\mathrm{Cu}$ & 5 & 5 & 4 & 11 & 76 & 6 & 10 \\
\hline $\mathrm{Zn}$ & 143 & 35 & 51 & 56 & 66 & 69 & 34 \\
\hline $\mathrm{Pb}$ & 11 & 16 & 15 & 17 & 6 & 46 & 12 \\
\hline $\mathrm{La}$ & 37 & 28 & 17 & 33 & 11 & 34 & 28 \\
\hline $\mathrm{Ce}$ & 71 & 54 & 35 & 55 & 31 & 49 & 48 \\
\hline Th & 6 & 9 & 5 & 11 & 3 & 16 & 7 \\
\hline $\mathrm{Nd}$ & 38 & 23 & 16 & 25 & 17 & 33 & 28 \\
\hline $\mathrm{U}$ & 4 & 3 & 1 & 4 & 2 & 3 & 1 \\
\hline
\end{tabular}




\section{A-2b : ICP-MS results}

\begin{tabular}{|c|c|c|c|c|c|c|c|c|}
\hline $\begin{array}{l}\text { Sample } \\
\text { ID }\end{array}$ & $\mathrm{B} 001 \mathrm{C}$ & B005 & B010 & B013 & B014 & B015 & B022 & B025B \\
\hline \multirow[t]{2}{*}{ Unit } & $\mathrm{R} 1$ & $\mathrm{R} 1$ & R3 & RT & $\mathrm{R} 8$ & R8 & R3 & R5 \\
\hline & \multicolumn{8}{|c|}{ This Study } \\
\hline \multicolumn{9}{|c|}{ ICP-MS data (ppm) } \\
\hline $\mathrm{La}$ & 17.71 & 22.82 & 25.65 & 40.68 & 26.27 & 26.46 & 22.59 & 24.36 \\
\hline $\mathrm{Ce}$ & 52.60 & 56.88 & 56.43 & 83.11 & 49.68 & 47.58 & 45.36 & 52.64 \\
\hline $\operatorname{Pr}$ & 4.77 & 6.68 & 6.41 & 10.79 & 5.61 & 5.59 & 5.65 & 5.16 \\
\hline $\mathrm{Nd}$ & 19.54 & 26.07 & 25.83 & 43.39 & 20.53 & 20.23 & 22.83 & 18.52 \\
\hline $\mathrm{Sm}$ & 5.00 & 6.20 & 6.21 & 10.26 & 4.18 & 4.33 & 5.54 & 3.95 \\
\hline $\mathrm{Eu}$ & 0.31 & 0.36 & 1.77 & 2.07 & 0.67 & 0.67 & 1.31 & 0.76 \\
\hline $\mathrm{Gd}$ & 5.45 & 5.35 & 5.93 & 10.40 & 4.06 & 4.03 & 5.61 & 3.68 \\
\hline $\mathrm{Tb}$ & 1.07 & 1.00 & 1.06 & 1.86 & 0.73 & 0.70 & 0.98 & 0.66 \\
\hline Dy & 7.52 & 6.61 & 6.75 & 12.45 & 4.65 & 4.65 & 6.36 & 4.33 \\
\hline Ho & 1.74 & 1.44 & 1.38 & 2.62 & 0.99 & 0.97 & 1.34 & 0.90 \\
\hline $\mathrm{Er}$ & 5.20 & 4.21 & 3.86 & 7.41 & 2.92 & 2.86 & 3.84 & 2.64 \\
\hline $\mathrm{Tm}$ & 0.84 & 0.70 & 0.58 & 1.16 & 0.47 & 0.46 & 0.59 & 0.42 \\
\hline $\mathrm{Yb}$ & 5.51 & 4.71 & 3.74 & 7.53 & 3.14 & 3.07 & 3.78 & 2.78 \\
\hline $\mathrm{Lu}$ & 0.87 & 0.74 & 0.59 & 1.23 & 0.50 & 0.49 & 0.62 & 0.43 \\
\hline $\mathrm{Ba}$ & 103 & 98 & 1763 & 1315 & 1509 & 1612 & 1107 & 1477 \\
\hline Th & 9.69 & 11.83 & 8.38 & 6.34 & 10.76 & 10.33 & 6.57 & 7.82 \\
\hline $\mathrm{Nb}$ & 10.79 & 13.41 & 11.29 & 19.03 & 9.49 & 9.10 & 9.39 & 10.75 \\
\hline Y & 37.68 & 33.21 & 34.69 & 66.95 & 27.70 & 27.37 & 35.59 & 23.84 \\
\hline $\mathrm{Hf}$ & 6.70 & 8.28 & 7.16 & 9.19 & 5.17 & 4.98 & 5.74 & 5.78 \\
\hline $\mathrm{Ta}$ & 0.80 & 1.03 & 0.87 & 1.21 & 0.91 & 0.88 & 0.70 & 0.90 \\
\hline $\mathrm{U}$ & 3.68 & 4.91 & 2.71 & 2.56 & 4.78 & 4.55 & 2.88 & 3.36 \\
\hline $\mathrm{Pb}$ & 37.02 & 8.51 & 13.98 & 14.13 & 15.05 & 14.46 & 11.67 & 12.80 \\
\hline $\mathrm{Rb}$ & 129.8 & 134.1 & 51.0 & 73.6 & 112.4 & 107.7 & 70.9 & 88.0 \\
\hline Cs & 3.29 & 3.38 & 1.39 & 2.79 & 5.27 & 5.21 & 2.59 & 2.73 \\
\hline $\mathrm{Sr}$ & 8 & 6 & 258 & 143 & 98 & 98 & 146 & 85 \\
\hline $\mathrm{Sc}$ & 1.5 & 2.2 & 12.2 & 3.3 & 4.1 & 4.1 & 9.5 & 3.1 \\
\hline $\mathrm{Zr}$ & 210 & 262 & 253 & 357 & 166 & 160 & 212 & 205 \\
\hline
\end{tabular}




\begin{tabular}{|c|c|c|c|c|c|c|c|c|}
\hline $\begin{array}{l}\text { Sample } \\
\text { ID }\end{array}$ & B026 & B108 & B109 & B110A & B110B & B111 & B112 & B116 \\
\hline \multirow[t]{2}{*}{ Unit } & R5 & R6 & R6 & $\mathrm{R} 2$ & Ba1 & $\mathrm{Ba} 2$ & R3 & R6 \\
\hline & \multicolumn{8}{|c|}{ This Study } \\
\hline \multicolumn{9}{|c|}{ ICP-MS data (ppm) } \\
\hline $\mathrm{La}$ & 27.33 & 25.91 & 21.21 & 28.97 & 11.18 & 20.70 & 24.83 & 27.98 \\
\hline $\mathrm{Ce}$ & 51.71 & 45.01 & 35.61 & 53.86 & 21.16 & 41.66 & 45.45 & 52.49 \\
\hline $\operatorname{Pr}$ & 6.01 & 5.35 & 3.72 & 6.02 & 3.00 & 5.54 & 5.67 & 6.39 \\
\hline $\mathrm{Nd}$ & 22.18 & 19.06 & 12.91 & 21.18 & 12.44 & 22.70 & 22.34 & 23.73 \\
\hline $\mathrm{Sm}$ & 4.73 & 3.99 & 2.52 & 4.40 & 3.25 & 5.07 & 4.96 & 5.11 \\
\hline $\mathrm{Eu}$ & 1.07 & 0.83 & 0.72 & 0.52 & 0.98 & 1.60 & 1.15 & 0.82 \\
\hline Gd & 4.54 & 3.46 & 2.20 & 4.12 & 3.59 & 5.00 & 4.98 & 4.49 \\
\hline $\mathrm{Tb}$ & 0.78 & 0.60 & 0.40 & 0.74 & 0.64 & 0.78 & 0.86 & 0.80 \\
\hline Dy & 4.96 & 3.88 & 2.64 & 4.89 & 4.09 & 4.82 & 5.46 & 4.84 \\
\hline Ho & 1.07 & 0.79 & 0.56 & 1.05 & 0.90 & 0.96 & 1.17 & 0.98 \\
\hline Er & 3.07 & 2.25 & 1.73 & 3.03 & 2.60 & 2.60 & 3.36 & 2.78 \\
\hline $\mathrm{Tm}$ & 0.49 & 0.37 & 0.28 & 0.50 & 0.37 & 0.38 & 0.51 & 0.44 \\
\hline $\mathrm{Yb}$ & 3.27 & 2.43 & 1.86 & 3.29 & 2.47 & 2.40 & 3.33 & 2.87 \\
\hline $\mathrm{Lu}$ & 0.52 & 0.39 & 0.30 & 0.53 & 0.40 & 0.38 & 0.53 & 0.44 \\
\hline $\mathrm{Ba}$ & 1507 & 1580 & 1536 & 1122 & 582 & 1456 & 1323 & 1555 \\
\hline Th & 6.71 & 8.96 & 8.63 & 12.49 & 2.67 & 2.13 & 6.84 & 8.72 \\
\hline $\mathrm{Nb}$ & 11.32 & 11.46 & 10.85 & 10.76 & 4.62 & 8.28 & 9.55 & 11.20 \\
\hline $\mathrm{Y}$ & 29.02 & 20.09 & 15.57 & 29.58 & 23.01 & 25.60 & 32.78 & 24.87 \\
\hline $\mathrm{Hf}$ & 7.20 & 5.96 & 5.93 & 4.31 & 2.77 & 3.45 & 5.47 & 5.86 \\
\hline $\mathrm{Ta}$ & 0.85 & 1.02 & 0.93 & 1.15 & 0.39 & 0.52 & 0.76 & 0.96 \\
\hline $\mathrm{U}$ & 2.91 & 3.33 & 3.02 & 5.50 & 1.02 & 0.89 & 3.06 & 3.32 \\
\hline $\mathrm{Pb}$ & 14.46 & 14.75 & 14.77 & 16.73 & 4.42 & 6.60 & 11.91 & 15.05 \\
\hline $\mathrm{Rb}$ & 80.6 & 95.7 & 93.0 & 124.8 & 24.3 & 25.3 & 76.6 & 94.5 \\
\hline Cs & 2.98 & 2.62 & 2.92 & 5.88 & 0.98 & 0.97 & 3.27 & 2.33 \\
\hline $\mathrm{Sr}$ & 163 & 85 & 83 & 55 & 230 & 548 & 240 & 87 \\
\hline $\mathrm{Sc}$ & 6.3 & 5.0 & 4.9 & 3.3 & 28.6 & 19.7 & 9.9 & 4.8 \\
\hline $\mathrm{Zr}$ & 284 & 216 & 208 & 127 & 105 & 141 & 211 & 210 \\
\hline
\end{tabular}




\begin{tabular}{|c|c|c|c|c|c|c|c|c|}
\hline $\begin{array}{l}\text { Sample } \\
\text { ID }\end{array}$ & B121A & B121B & B126 & B129 & B138 & B144 & B146 & B147 \\
\hline \multirow[t]{2}{*}{ Unit } & R8 & R8 & RT & $\mathrm{R} 8$ & R6 & $\mathrm{R} 8$ & R5 & $\mathrm{R} 2$ \\
\hline & \multicolumn{8}{|c|}{ This Study } \\
\hline \multicolumn{9}{|c|}{ ICP-MS data (ppm) } \\
\hline $\mathrm{La}$ & 25.89 & 25.97 & 54.29 & 25.45 & 26.52 & 21.42 & 25.79 & 28.73 \\
\hline $\mathrm{Ce}$ & 48.50 & 49.31 & 90.78 & 47.77 & 50.95 & 41.01 & 44.50 & 53.52 \\
\hline $\operatorname{Pr}$ & 5.59 & 5.55 & 12.96 & 5.52 & 5.47 & 4.76 & 5.70 & 6.00 \\
\hline $\mathrm{Nd}$ & 19.87 & 20.18 & 50.39 & 19.78 & 19.74 & 17.87 & 20.46 & 21.23 \\
\hline $\mathrm{Sm}$ & 3.96 & 4.22 & 10.86 & 4.12 & 4.13 & 3.89 & 4.24 & 4.45 \\
\hline $\mathrm{Eu}$ & 0.63 & 0.63 & 2.36 & 0.62 & 0.80 & 0.74 & 0.83 & 0.52 \\
\hline Gd & 3.80 & 3.90 & 10.53 & 3.78 & 3.70 & 3.80 & 4.08 & 4.12 \\
\hline $\mathrm{Tb}$ & 0.70 & 0.71 & 1.82 & 0.69 & 0.67 & 0.69 & 0.72 & 0.74 \\
\hline Dy & 4.51 & 4.43 & 11.44 & 4.48 & 4.11 & 4.43 & 4.58 & 4.82 \\
\hline Ho & 0.97 & 0.98 & 2.38 & 0.95 & 0.87 & 0.93 & 0.95 & 1.04 \\
\hline Er & 2.87 & 2.93 & 6.79 & 2.83 & 2.61 & 2.82 & 2.80 & 3.09 \\
\hline $\mathrm{Tm}$ & 0.46 & 0.46 & 1.01 & 0.46 & 0.40 & 0.44 & 0.43 & 0.50 \\
\hline $\mathrm{Yb}$ & 3.17 & 3.13 & 6.36 & 3.01 & 2.75 & 2.90 & 2.86 & 3.28 \\
\hline $\mathrm{Lu}$ & 0.52 & 0.50 & 0.99 & 0.49 & 0.44 & 0.47 & 0.45 & 0.52 \\
\hline $\mathrm{Ba}$ & 1479 & 1482 & 1572 & 1436 & 1552 & 1406 & 1394 & 1138 \\
\hline Th & 10.91 & 11.02 & 6.88 & 10.72 & 8.86 & 8.48 & 9.62 & 12.51 \\
\hline $\mathrm{Nb}$ & 9.64 & 9.59 & 22.22 & 9.46 & 10.81 & 8.32 & 8.76 & 10.64 \\
\hline $\mathrm{Y}$ & 26.81 & 27.39 & 63.79 & 26.85 & 22.50 & 26.58 & 25.75 & 29.18 \\
\hline $\mathrm{Hf}$ & 4.91 & 4.83 & 9.47 & 4.79 & 5.63 & 4.32 & 4.66 & 4.31 \\
\hline $\mathrm{Ta}$ & 0.92 & 0.92 & 1.38 & 0.91 & 0.94 & 0.79 & 0.84 & 1.13 \\
\hline $\mathrm{U}$ & 4.36 & 4.76 & 3.18 & 4.61 & 3.50 & 3.58 & 4.11 & 5.37 \\
\hline $\mathrm{Pb}$ & 14.77 & 14.98 & 12.89 & 14.65 & 15.20 & 11.44 & 12.62 & 16.65 \\
\hline $\mathrm{Rb}$ & 113.5 & 113.0 & 60.6 & 111.3 & 98.4 & 89.9 & 117.9 & 125.0 \\
\hline Cs & 3.61 & 5.31 & 1.54 & 5.16 & 3.11 & 4.82 & 5.50 & 5.81 \\
\hline $\mathrm{Sr}$ & 92 & 88 & 108 & 90 & 85 & 148 & 113 & 55 \\
\hline $\mathrm{Sc}$ & 4.0 & 3.9 & 6.0 & 3.6 & 4.7 & 6.8 & 5.9 & 3.1 \\
\hline $\mathrm{Zr}$ & 157 & 156 & 371 & 153 & 192 & 145 & 152 & 126 \\
\hline
\end{tabular}




\begin{tabular}{|c|c|c|c|c|c|c|c|c|}
\hline $\begin{array}{l}\text { Sample } \\
\text { ID }\end{array}$ & B148 & B153 & B155 & B156 & B158 & B159 & B160 & B161 \\
\hline \multirow[t]{2}{*}{ Unit } & $\mathrm{R} 2$ & (R5) & $\mathrm{R} 4$ & $\mathrm{R} 4$ & $\mathrm{R} 4$ & R5 & R5 & R5 \\
\hline & \multicolumn{8}{|c|}{ This Study } \\
\hline \multicolumn{9}{|c|}{ ICP-MS data (ppm) } \\
\hline $\mathrm{La}$ & 19.65 & 21.19 & 26.86 & 29.02 & 21.23 & 23.97 & 22.76 & 23.68 \\
\hline $\mathrm{Ce}$ & 36.35 & 32.51 & 48.12 & 52.90 & 46.32 & 46.86 & 43.90 & 43.79 \\
\hline $\operatorname{Pr}$ & 4.19 & 4.48 & 6.17 & 7.15 & 4.64 & 5.58 & 5.16 & 5.00 \\
\hline $\mathrm{Nd}$ & 14.90 & 16.27 & 23.21 & 27.46 & 17.82 & 20.54 & 18.73 & 18.05 \\
\hline $\mathrm{Sm}$ & 3.29 & 3.30 & 5.19 & 6.16 & 4.07 & 4.30 & 4.03 & 3.82 \\
\hline $\mathrm{Eu}$ & 0.54 & 0.46 & 0.93 & 1.04 & 0.99 & 0.92 & 0.83 & 0.68 \\
\hline Gd & 2.78 & 2.69 & 4.75 & 5.73 & 3.97 & 4.04 & 3.82 & 3.51 \\
\hline $\mathrm{Tb}$ & 0.49 & 0.44 & 0.86 & 1.00 & 0.74 & 0.72 & 0.66 & 0.63 \\
\hline Dy & 3.02 & 2.61 & 5.49 & 6.22 & 4.84 & 4.57 & 4.18 & 4.05 \\
\hline Ho & 0.66 & 0.51 & 1.17 & 1.29 & 1.05 & 0.98 & 0.87 & 0.87 \\
\hline $\mathrm{Er}$ & 1.84 & 1.45 & 3.48 & 3.63 & 3.14 & 2.85 & 2.48 & 2.59 \\
\hline $\mathrm{Tm}$ & 0.30 & 0.24 & 0.55 & 0.55 & 0.49 & 0.45 & 0.39 & 0.41 \\
\hline $\mathrm{Yb}$ & 1.88 & 1.68 & 3.56 & 3.56 & 3.25 & 2.97 & 2.58 & 2.71 \\
\hline $\mathrm{Lu}$ & 0.31 & 0.26 & 0.58 & 0.54 & 0.52 & 0.49 & 0.42 & 0.46 \\
\hline $\mathrm{Ba}$ & 1110 & 1954 & 1373 & 1509 & 1505 & 1265 & 1291 & 1361 \\
\hline Th & 7.94 & 7.16 & 11.38 & 12.81 & 11.33 & 8.39 & 8.66 & 9.37 \\
\hline $\mathrm{Nb}$ & 6.95 & 5.23 & 11.43 & 13.04 & 12.14 & 8.70 & 8.03 & 7.22 \\
\hline $\mathrm{Y}$ & 17.71 & 12.54 & 31.22 & 32.30 & 27.53 & 26.60 & 23.46 & 24.31 \\
\hline $\mathrm{Hf}$ & 3.70 & 3.23 & 7.22 & 8.29 & 7.83 & 4.60 & 4.59 & 4.66 \\
\hline $\mathrm{Ta}$ & 0.67 & 0.59 & 0.91 & 1.03 & 0.95 & 0.80 & 0.71 & 0.67 \\
\hline $\mathrm{U}$ & 2.89 & 1.05 & 4.15 & 5.13 & 4.68 & 3.60 & 3.58 & 3.33 \\
\hline $\mathrm{Pb}$ & 11.83 & 6.39 & 17.70 & 12.90 & 11.87 & 12.80 & 11.03 & 12.01 \\
\hline $\mathrm{Rb}$ & 84.8 & 71.5 & 99.1 & 143.0 & 122.2 & 122.9 & 95.9 & 105.0 \\
\hline Cs & 2.82 & 7.67 & 4.18 & 4.50 & 5.64 & 12.27 & 4.00 & 5.26 \\
\hline $\mathrm{Sr}$ & 76 & 451 & 69 & 75 & 75 & 158 & 153 & 98 \\
\hline $\mathrm{Sc}$ & 2.7 & 2.6 & 4.8 & 6.6 & 5.9 & 11.2 & 10.1 & 4.6 \\
\hline $\mathrm{Zr}$ & 121 & 108 & 272 & 311 & 298 & 152 & 153 & 147 \\
\hline
\end{tabular}




\begin{tabular}{|c|c|c|c|c|c|c|c|c|}
\hline $\begin{array}{l}\text { Sample } \\
\text { ID }\end{array}$ & B162 & B163 & B165 & B168 & B171 & $\mathrm{B} 175$ & B178 & B185 \\
\hline \multirow[t]{2}{*}{ Unit } & R6 & R6 & (R6) & (R6) & R6 & R6 & R7 & $\mathrm{R} 2$ \\
\hline & \multicolumn{8}{|c|}{ This Study } \\
\hline \multicolumn{9}{|c|}{ ICP-MS data (ppm) } \\
\hline $\mathrm{La}$ & 30.00 & 29.93 & 33.30 & 16.47 & 29.14 & 36.04 & 17.55 & 26.01 \\
\hline $\mathrm{Ce}$ & 53.77 & 55.15 & 61.39 & 32.39 & 54.94 & 62.24 & 38.32 & 47.53 \\
\hline $\operatorname{Pr}$ & 6.69 & 6.36 & 7.70 & 4.04 & 6.45 & 9.58 & 4.41 & 5.47 \\
\hline $\mathrm{Nd}$ & 24.37 & 22.95 & 29.86 & 15.15 & 23.71 & 37.29 & 17.63 & 19.36 \\
\hline $\mathrm{Sm}$ & 5.16 & 4.84 & 6.52 & 3.24 & 4.94 & 8.52 & 4.28 & 4.18 \\
\hline $\mathrm{Eu}$ & 0.79 & 0.81 & 1.69 & 0.91 & 0.92 & 1.28 & 0.84 & 0.46 \\
\hline $\mathrm{Gd}$ & 4.55 & 4.53 & 6.43 & 3.02 & 4.57 & 8.75 & 4.29 & 3.78 \\
\hline $\mathrm{Tb}$ & 0.80 & 0.83 & 1.09 & 0.51 & 0.81 & 1.53 & 0.74 & 0.69 \\
\hline Dy & 5.14 & 5.41 & 7.02 & 3.31 & 5.34 & 9.81 & 4.91 & 4.60 \\
\hline Ho & 1.07 & 1.15 & 1.44 & 0.69 & 1.13 & 2.08 & 1.03 & 0.98 \\
\hline $\mathrm{Er}$ & 3.02 & 3.35 & 4.04 & 1.97 & 3.15 & 5.84 & 2.92 & 2.90 \\
\hline $\mathrm{Tm}$ & 0.47 & 0.52 & 0.62 & 0.31 & 0.50 & 0.90 & 0.46 & 0.47 \\
\hline $\mathrm{Yb}$ & 3.03 & 3.45 & 4.04 & 2.04 & 3.31 & 5.76 & 2.93 & 3.07 \\
\hline $\mathrm{Lu}$ & 0.47 & 0.54 & 0.64 & 0.33 & 0.53 & 0.90 & 0.45 & 0.50 \\
\hline $\mathrm{Ba}$ & 1603 & 1567 & 1476 & 3876 & 1530 & 1466 & 1709 & 1051 \\
\hline Th & 8.81 & 9.03 & 7.08 & 4.50 & 8.70 & 10.93 & 4.97 & 11.72 \\
\hline $\mathrm{Nb}$ & 11.16 & 10.93 & 14.09 & 9.19 & 9.83 & 9.11 & 6.30 & 9.46 \\
\hline $\mathrm{Y}$ & 28.69 & 31.57 & 38.70 & 18.72 & 29.89 & 55.33 & 27.38 & 27.66 \\
\hline $\mathrm{Hf}$ & 5.75 & 5.84 & 6.98 & 4.38 & 5.73 & 6.78 & 4.57 & 3.87 \\
\hline $\mathrm{Ta}$ & 0.95 & 0.94 & 1.03 & 0.67 & 0.85 & 0.69 & 0.49 & 1.07 \\
\hline $\mathrm{U}$ & 3.22 & 3.35 & 2.78 & 1.14 & 3.34 & 4.76 & 0.76 & 4.37 \\
\hline $\mathrm{Pb}$ & 14.43 & 14.32 & 12.97 & 4.52 & 14.81 & 14.29 & 4.22 & 15.17 \\
\hline $\mathrm{Rb}$ & 99.6 & 99.6 & 75.3 & 46.0 & 91.1 & 125.2 & 64.0 & 106.8 \\
\hline Cs & 3.61 & 3.20 & 1.67 & 31.45 & 2.93 & 3.55 & 9.85 & 5.77 \\
\hline $\mathrm{Sr}$ & 84 & 87 & 181 & 612 & 89 & 57 & 189 & 188 \\
\hline $\mathrm{Sc}$ & 5.2 & 5.1 & 9.5 & 5.0 & 4.8 & 6.8 & 4.9 & 2.9 \\
\hline $\mathrm{Zr}$ & 195 & 198 & 259 & 165 & 193 & 235 & 168 & 111 \\
\hline
\end{tabular}




\begin{tabular}{|c|c|c|c|c|c|c|c|}
\hline $\begin{array}{l}\text { Sample } \\
\text { ID }\end{array}$ & B191 & B352 & B354 & B355 & B356 & EJ-03 & EJ-04 \\
\hline \multirow[t]{2}{*}{ Unit } & RT & R6 & R7 & R6 & $\mathrm{Ba} 1$ & $\mathrm{R} 1$ & R6 \\
\hline & \multicolumn{4}{|c|}{ This Study } & & \multicolumn{2}{|c|}{ Hess, 2014} \\
\hline \multicolumn{8}{|c|}{ ICP-MS data (ppm) } \\
\hline $\mathrm{La}$ & 36.28 & 28.51 & 17.61 & 28.86 & 13.56 & 32.04 & 28.32 \\
\hline $\mathrm{Ce}$ & 76.71 & 52.95 & 36.33 & 57.23 & 27.72 & 47.37 & 45.70 \\
\hline $\operatorname{Pr}$ & 9.92 & 6.20 & 4.55 & 6.99 & 3.59 & 8.93 & 7.41 \\
\hline $\mathrm{Nd}$ & 40.28 & 22.73 & 17.88 & 27.41 & 15.17 & 33.59 & 29.04 \\
\hline $\mathrm{Sm}$ & 9.42 & 4.98 & 4.14 & 6.25 & 3.69 & 7.32 & 6.68 \\
\hline $\mathrm{Eu}$ & 2.47 & 0.75 & 0.88 & 1.20 & 1.20 & 0.43 & 1.25 \\
\hline Gd & 9.15 & 4.47 & 3.54 & 6.23 & 4.13 & 6.03 & 6.10 \\
\hline $\mathrm{Tb}$ & 1.55 & 0.80 & 0.58 & 1.14 & 0.71 & 1.11 & 1.12 \\
\hline Dy & 9.73 & 5.32 & 3.35 & 7.29 & 4.45 & 7.14 & 7.31 \\
\hline Но & 2.05 & 1.12 & 0.64 & 1.58 & 0.95 & 1.51 & 1.58 \\
\hline Er & 5.60 & 3.29 & 1.71 & 4.66 & 2.62 & 4.39 & 4.53 \\
\hline $\mathrm{Tm}$ & 0.83 & 0.51 & 0.24 & 0.73 & 0.40 & 0.68 & 0.69 \\
\hline $\mathrm{Yb}$ & 5.40 & 3.37 & 1.57 & 4.72 & 2.49 & 4.62 & 4.42 \\
\hline $\mathrm{Lu}$ & 0.84 & 0.55 & 0.24 & 0.82 & 0.39 & 0.72 & 0.69 \\
\hline $\mathrm{Ba}$ & 1340 & 1555 & 1011 & 1434 & 733 & 153 & 627 \\
\hline Th & 5.76 & 8.96 & 7.25 & 10.95 & 3.58 & 13.00 & 7.72 \\
\hline $\mathrm{Nb}$ & 18.98 & 11.11 & 10.38 & 11.46 & 6.54 & 9.28 & 7.60 \\
\hline $\mathrm{Y}$ & 53.19 & 30.74 & 15.14 & 42.60 & 24.31 & 34.19 & 37.18 \\
\hline $\mathrm{Hf}$ & 7.86 & 5.85 & 6.82 & 6.95 & 3.34 & 8.87 & 6.14 \\
\hline $\mathrm{Ta}$ & 1.21 & 0.97 & 0.79 & 0.93 & 0.52 & 0.47 & 0.46 \\
\hline $\mathrm{U}$ & 2.43 & 3.88 & 1.14 & 5.04 & 1.27 & 4.41 & 2.83 \\
\hline $\mathrm{Pb}$ & 11.02 & 15.36 & 12.65 & 14.96 & 5.58 & 43.86 & 11.97 \\
\hline $\mathrm{Rb}$ & 54.8 & 103.4 & 43.6 & 208.8 & 12.9 & 178.5 & 100.6 \\
\hline Cs & 2.48 & 4.54 & 5.48 & 5.51 & 0.92 & 2.77 & 3.96 \\
\hline $\mathrm{Sr}$ & 216 & 92 & 232 & 61 & 271 & 8 & 24 \\
\hline $\mathrm{Sc}$ & 14.1 & 5.0 & 6.2 & 6.7 & 25.9 & 2.6 & 4.4 \\
\hline $\mathrm{Zr}$ & 311 & 196 & 244 & 241 & 123 & 282 & 215 \\
\hline
\end{tabular}




\section{A-2c : Analytical error}

\begin{tabular}{|c|c|c|c|c|}
\hline & B109 & $\begin{array}{c}\mathrm{B} 109 \\
\text { replicate }\end{array}$ & $\begin{array}{c}\text { Standard } \\
\text { Deviation }\end{array}$ & $\begin{array}{c}\text { Percent } \\
\text { Error }\end{array}$ \\
\hline \multicolumn{5}{|c|}{ XRF- wt\% (normalized) } \\
\hline $\mathrm{SiO} 2$ & 76.36 & 76.38 & 0.01 & 0.03 \\
\hline $\mathrm{TiO} 2$ & 0.182 & 0.184 & 0.00 & 1.22 \\
\hline $\mathrm{Al} 2 \mathrm{O} 3$ & 13.11 & 13.09 & 0.02 & 0.19 \\
\hline $\mathrm{FeO} *$ & 1.23 & 1.24 & 0.01 & 0.88 \\
\hline $\mathrm{MnO}$ & 0.008 & 0.008 & 0.00 & 0.69 \\
\hline $\mathrm{MgO}$ & 0.12 & 0.11 & 0.01 & 11.11 \\
\hline $\mathrm{CaO}$ & 0.83 & 0.84 & 0.00 & 0.82 \\
\hline $\mathrm{Na} 2 \mathrm{O}$ & 3.91 & 3.87 & 0.03 & 1.00 \\
\hline $\mathrm{K} 2 \mathrm{O}$ & 4.22 & 4.26 & 0.03 & 0.85 \\
\hline $\mathrm{P} 2 \mathrm{O} 5$ & 0.016 & 0.017 & 0.00 & 7.58 \\
\hline \multicolumn{5}{|c|}{ XRF- ppm (unnormalized): } \\
\hline $\mathrm{Ni}$ & 1.1904 & 1.984 & 0.56 & 66.67 \\
\hline $\mathrm{Cr}$ & 4.7616 & 3.7696 & 0.70 & 20.83 \\
\hline $\mathrm{Sc}$ & 5.456 & 5.6544 & 0.14 & 3.64 \\
\hline $\mathrm{V}$ & 13.9872 & 12.9952 & 0.70 & 7.09 \\
\hline $\mathrm{Ba}$ & 1388.8 & 1484.2304 & 67.48 & 6.87 \\
\hline $\mathrm{Rb}$ & 91.1648 & 96.8192 & 4.00 & 6.20 \\
\hline $\mathrm{Sr}$ & 77.376 & 83.4272 & 4.28 & 7.82 \\
\hline $\mathrm{Zr}$ & 188.2816 & 200.2848 & 8.49 & 6.38 \\
\hline $\mathrm{Y}$ & 14.6816 & 16.1696 & 1.05 & 10.14 \\
\hline $\mathrm{Nb}$ & 10.2176 & 10.7136 & 0.35 & 4.85 \\
\hline $\mathrm{Ga}$ & 13.5904 & 14.5824 & 0.70 & 7.30 \\
\hline $\mathrm{Cu}$ & 4.0672 & 4.464 & 0.28 & 9.76 \\
\hline $\mathrm{Zn}$ & 24.8 & 27.0816 & 1.61 & 9.20 \\
\hline $\mathrm{Pb}$ & 14.4832 & 16.9632 & 1.75 & 17.12 \\
\hline $\mathrm{La}$ & 17.36 & 19.6416 & 1.61 & 13.14 \\
\hline $\mathrm{Ce}$ & 29.3632 & 33.728 & 3.09 & 14.86 \\
\hline Th & 7.5392 & 9.1264 & 1.12 & 21.05 \\
\hline $\mathrm{Nd}$ & 10.7136 & 13.392 & 1.89 & 25.00 \\
\hline $\mathrm{U}$ & 2.2816 & 2.6784 & 0.28 & 17.39 \\
\hline
\end{tabular}




\begin{tabular}{|c|c|c|c|c|}
\hline & B109 & $\begin{array}{c}\text { B109 } \\
\text { replicate }\end{array}$ & $\begin{array}{c}\text { Standard } \\
\text { Deviation }\end{array}$ & $\begin{array}{c}\text { Percent } \\
\text { Error } \\
\end{array}$ \\
\hline \multicolumn{5}{|c|}{ ICP-MS data (ppm) } \\
\hline $\mathrm{La}$ & 21.21 & 21.50 & 0.20 & 1.34 \\
\hline $\mathrm{Ce}$ & 35.61 & 36.04 & 0.30 & 1.20 \\
\hline $\operatorname{Pr}$ & 3.72 & 3.79 & 0.05 & 1.87 \\
\hline $\mathrm{Nd}$ & 12.91 & 12.93 & 0.01 & 0.13 \\
\hline $\mathrm{Sm}$ & 2.52 & 2.45 & 0.05 & 3.08 \\
\hline $\mathrm{Eu}$ & 0.72 & 0.71 & 0.01 & 1.67 \\
\hline $\mathrm{Gd}$ & 2.20 & 2.26 & 0.04 & 2.69 \\
\hline $\mathrm{Tb}$ & 0.40 & 0.41 & 0.01 & 3.37 \\
\hline Dy & 2.64 & 2.74 & 0.07 & 3.83 \\
\hline Но & 0.56 & 0.58 & 0.01 & 2.05 \\
\hline Er & 1.73 & 1.73 & 0.00 & 0.06 \\
\hline $\mathrm{Tm}$ & 0.28 & 0.28 & 0.00 & 0.83 \\
\hline $\mathrm{Yb}$ & 1.86 & 1.90 & 0.03 & 2.35 \\
\hline $\mathrm{Lu}$ & 0.30 & 0.31 & 0.01 & 5.04 \\
\hline $\mathrm{Ba}$ & 1536.09 & 1534.89 & 0.84 & 0.08 \\
\hline Th & 8.63 & 8.63 & 0.00 & 0.02 \\
\hline $\mathrm{Nb}$ & 10.85 & 10.98 & 0.09 & 1.20 \\
\hline Y & 15.57 & 15.55 & 0.01 & 0.12 \\
\hline Hf & 5.93 & 6.01 & 0.06 & 1.40 \\
\hline $\mathrm{Ta}$ & 0.93 & 0.95 & 0.01 & 1.60 \\
\hline $\mathrm{U}$ & 3.02 & 2.92 & 0.07 & 3.10 \\
\hline $\mathrm{Pb}$ & 14.77 & 14.66 & 0.08 & 0.75 \\
\hline $\mathrm{Rb}$ & 92.97 & 93.07 & 0.07 & 0.10 \\
\hline Cs & 2.92 & 2.94 & 0.02 & 0.74 \\
\hline $\mathrm{Sr}$ & 82.54 & 82.53 & 0.01 & 0.01 \\
\hline $\mathrm{Sc}$ & 4.90 & 5.12 & 0.16 & 4.50 \\
\hline $\mathrm{Zr}$ & 208.27 & 205.55 & 1.92 & 1.30 \\
\hline
\end{tabular}




\begin{tabular}{lcccc}
\hline \hline & $\mathrm{B} 163$ & $\begin{array}{c}\text { B163 } \\
\text { replicate }\end{array}$ & $\begin{array}{c}\text { Standard } \\
\text { Deviation }\end{array}$ & $\begin{array}{c}\text { Percent } \\
\text { Error }\end{array}$ \\
\hline $\begin{array}{l}\text { XRF-wt\% } \\
\text { (normalized) }\end{array}$ & & & & \\
$\mathrm{SiO} 2$ & 75.82 & 75.83 & 0.00 & 0.00 \\
$\mathrm{TiO} 2$ & 0.183 & 0.182 & 0.00 & 0.68 \\
$\mathrm{~A} 12 \mathrm{O} 3$ & 13.27 & 13.29 & 0.02 & 0.21 \\
$\mathrm{FeO} *$ & 1.22 & 1.24 & 0.01 & 1.53 \\
$\mathrm{MnO}$ & 0.015 & 0.016 & 0.00 & 2.36 \\
$\mathrm{MgO}$ & 0.09 & 0.08 & 0.00 & 3.58 \\
$\mathrm{CaO}$ & 0.89 & 0.88 & 0.00 & 0.30 \\
$\mathrm{Na} 2 \mathrm{O}$ & 3.94 & 3.91 & 0.02 & 0.87 \\
$\mathrm{~K} 2 \mathrm{O}$ & 4.56 & 4.55 & 0.00 & 0.12 \\
$\mathrm{P} 2 \mathrm{O} 5$ & 0.022 & 0.019 & 0.00 & 12.69
\end{tabular}

XRF- ppm (unnormalized):

\begin{tabular}{lcccc}
$\mathrm{Ni}$ & 2.1824 & 3.0752 & 0.63 & 40.91 \\
$\mathrm{Cr}$ & 3.1744 & 4.5632 & 0.98 & 43.75 \\
$\mathrm{Sc}$ & 5.456 & 5.2576 & 0.14 & 3.64 \\
$\mathrm{~V}$ & 10.2176 & 10.0192 & 0.14 & 1.94 \\
$\mathrm{Ba}$ & 1511.907 & 1507.5424 & 3.09 & 0.29 \\
$\mathrm{Rb}$ & 102.8704 & 104.0608 & 0.84 & 1.16 \\
$\mathrm{Sr}$ & 87.6928 & 87.792 & 0.07 & 0.11 \\
$\mathrm{Zr}$ & 194.1344 & 195.1264 & 0.70 & 0.51 \\
$\mathrm{Y}$ & 32.5376 & 31.6448 & 0.63 & 2.74 \\
$\mathrm{Nb}$ & 11.0112 & 11.7056 & 0.49 & 6.31 \\
$\mathrm{Ga}$ & 14.7808 & 14.0864 & 0.49 & 4.70 \\
$\mathrm{Cu}$ & 5.0592 & 5.0592 & 0.00 & 0.00 \\
$\mathrm{Zn}$ & 31.8432 & 32.0416 & 0.14 & 0.62 \\
$\mathrm{~Pb}$ & 14.5824 & 14.7808 & 0.14 & 1.36 \\
$\mathrm{La}$ & 28.272 & 27.6768 & 0.42 & 2.11 \\
$\mathrm{Ce}$ & 49.9968 & 48.9056 & 0.77 & 2.18 \\
$\mathrm{Th}$ & 9.424 & 9.5232 & 0.07 & 1.05 \\
$\mathrm{Nd}$ & 20.4352 & 22.0224 & 1.12 & 7.77 \\
$\mathrm{U}$ & 3.2736 & 4.464 & 0.84 & 36.36 \\
\hline
\end{tabular}




\begin{tabular}{|c|c|c|c|c|}
\hline & $\mathrm{B} 163$ & $\begin{array}{c}\mathrm{B} 163 \\
\text { replicate }\end{array}$ & $\begin{array}{c}\text { Standard } \\
\text { Deviation }\end{array}$ & $\begin{array}{c}\text { Percent } \\
\text { Error }\end{array}$ \\
\hline \multicolumn{5}{|c|}{ ICP-MS data (ppm) } \\
\hline $\mathrm{La}$ & 29.93 & 29.32 & 0.43 & 2.03 \\
\hline $\mathrm{Ce}$ & 55.15 & 54.36 & 0.56 & 1.44 \\
\hline $\operatorname{Pr}$ & 6.36 & 6.30 & 0.05 & 1.02 \\
\hline $\mathrm{Nd}$ & 22.95 & 22.76 & 0.14 & 0.84 \\
\hline $\mathrm{Sm}$ & 4.84 & 4.80 & 0.02 & 0.71 \\
\hline $\mathrm{Eu}$ & 0.81 & 0.84 & 0.02 & 3.91 \\
\hline $\mathrm{Gd}$ & 4.53 & 4.43 & 0.07 & 2.10 \\
\hline $\mathrm{Tb}$ & 0.83 & 0.83 & 0.01 & 0.85 \\
\hline Dy & 5.41 & 5.30 & 0.07 & 1.96 \\
\hline Ho & 1.15 & 1.15 & 0.00 & 0.43 \\
\hline Er & 3.35 & 3.26 & 0.06 & 2.68 \\
\hline $\mathrm{Tm}$ & 0.52 & 0.51 & 0.01 & 1.52 \\
\hline $\mathrm{Yb}$ & 3.45 & 3.41 & 0.03 & 1.28 \\
\hline $\mathrm{Lu}$ & 0.54 & 0.53 & 0.01 & 1.56 \\
\hline $\mathrm{Ba}$ & 1567.25 & 1550.96 & 11.51 & 1.04 \\
\hline Th & 9.03 & 9.03 & 0.00 & 0.05 \\
\hline $\mathrm{Nb}$ & 10.93 & 10.92 & 0.01 & 0.08 \\
\hline $\mathrm{Y}$ & 31.57 & 31.27 & 0.21 & 0.93 \\
\hline $\mathrm{Hf}$ & 5.84 & 5.69 & 0.10 & 2.46 \\
\hline $\mathrm{Ta}$ & 0.94 & 0.93 & 0.01 & 1.26 \\
\hline $\mathrm{U}$ & 3.35 & 3.49 & 0.10 & 4.35 \\
\hline $\mathrm{Pb}$ & 14.32 & 14.29 & 0.02 & 0.24 \\
\hline $\mathrm{Rb}$ & 99.64 & 99.74 & 0.07 & 0.10 \\
\hline Cs & 3.20 & 3.12 & 0.06 & 2.53 \\
\hline $\mathrm{Sr}$ & 87.17 & 87.27 & 0.07 & 0.12 \\
\hline $\mathrm{Sc}$ & 5.11 & 5.01 & 0.07 & 1.91 \\
\hline $\mathrm{Zr}$ & 197.67 & 196.16 & 1.07 & 0.77 \\
\hline
\end{tabular}




\section{Appendix A-3 : Sample Locations}

\begin{tabular}{|c|c|c|c|c|c|c|}
\hline $\begin{array}{l}\text { Sample } \\
\text { ID }\end{array}$ & $\begin{array}{c}\text { Geographic } \\
\text { Unit }\end{array}$ & Unit & Latitude & Longitude & Thinsection & $\begin{array}{c}\mathrm{XRF} / \mathrm{ICP}- \\
\mathrm{MS}\end{array}$ \\
\hline B001C & $1 \mathrm{~A}$ & R1 & 43.645 & -118.63 & & $X$ \\
\hline B005 & $1 \mathrm{~A}$ & $\mathrm{R} 1$ & 43.64 & -118.62 & $X$ & $\mathrm{X}$ \\
\hline B010 & $1 \mathrm{~B}$ & $\mathrm{R} 3$ & 43.639 & -118.62 & $X$ & $\mathrm{X}$ \\
\hline B013 & $3 \mathrm{~F}$ & RT & 43.637 & -118.61 & & $X$ \\
\hline B014 & $5 \mathrm{~A}$ & R8 & 43.637 & -118.61 & & $X$ \\
\hline B015 & $5 \mathrm{~A}$ & $\mathrm{R} 8$ & 43.633 & -118.61 & & $X$ \\
\hline B022 & $1 \mathrm{~B}$ & R3 & 43.624 & -118.62 & & $X$ \\
\hline B025B & $5 B$ & R5 & 43.651 & -118.53 & $X$ & $X$ \\
\hline B026 & $5 B$ & R5 & 43.652 & -118.53 & & $X$ \\
\hline B108 & $4 \mathrm{~A}$ & R6 & 43.565 & -118.52 & $X$ & $X$ \\
\hline B109 & $4 \mathrm{~A}$ & R6 & 43.565 & -118.53 & $X$ & $X$ \\
\hline B110A & $4 B$ & $\mathrm{R} 2$ & 43.565 & -118.53 & & $\mathrm{X}$ \\
\hline B110B & b4A & Ba1 & 43.565 & -118.53 & $\mathrm{X}$ & $X$ \\
\hline B111 & b4B & $\mathrm{Ba} 2$ & 43.563 & -118.53 & & $X$ \\
\hline B112 & $4 \mathrm{C}$ & $\mathrm{R} 3$ & 43.558 & -118.53 & $X$ & $X$ \\
\hline B114 & $4 \mathrm{C}$ & R3 & 43.556 & -118.53 & $X$ & \\
\hline B116 & $4 \mathrm{~A}$ & R6 & 43.574 & -118.52 & & $X$ \\
\hline B121A & $3 \mathrm{E}$ & $\mathrm{R} 8$ & 43.649 & -118.55 & $X$ & $X$ \\
\hline B121B & $3 \mathrm{E}$ & R8 & 43.649 & -118.55 & & $X$ \\
\hline B126 & $3 F$ & RT & 43.645 & -118.57 & & $X$ \\
\hline B129 & $3 \mathrm{E}$ & R6 & 43.642 & -118.56 & & $X$ \\
\hline B131 & $3 \mathrm{E}$ & $\mathrm{R} 8$ & 43.639 & -118.56 & $X$ & \\
\hline B138 & $3 \mathrm{D}$ & R6 & 43.629 & -118.56 & $X$ & $X$ \\
\hline B144 & $3 \mathrm{E}$ & $\mathrm{R} 8$ & 43.617 & -118.59 & $X$ & $X$ \\
\hline B146 & $3 C$ & R5 & 43.615 & -118.59 & & $X$ \\
\hline B147 & $3 \mathrm{~A}$ & $\mathrm{R} 2$ & 43.613 & -118.59 & & $X$ \\
\hline B148 & $3 \mathrm{~A}$ & R2 & 43.614 & -118.59 & & $X$ \\
\hline
\end{tabular}




\begin{tabular}{ccccccc}
\hline \hline $\begin{array}{c}\text { Sample } \\
\text { ID }\end{array}$ & $\begin{array}{c}\text { Geographic } \\
\text { Unit }\end{array}$ & Unit & Latitude & Longitude & Thinsection & $\begin{array}{c}\text { XRF/ICP- } \\
\text { MS }\end{array}$ \\
\hline B153 & 3C & (R5) & 43.613 & -118.56 & $\mathrm{X}$ & $\mathrm{X}$ \\
B155 & 3B & R4 & 43.614 & -118.56 & $\mathrm{X}$ & $\mathrm{X}$ \\
B156 & 3B & R4 & 43.615 & -118.57 & & $\mathrm{X}$ \\
B158 & 3B & R4 & 43.616 & -118.56 & & $\mathrm{X}$ \\
B159 & 3C & R5 & 43.616 & -118.56 & $\mathrm{X}$ & $\mathrm{X}$ \\
B160 & 3C & R5 & 43.617 & -118.56 & & $\mathrm{X}$ \\
B161 & 3C & R5 & 43.617 & -118.56 & & $\mathrm{X}$ \\
B162 & 3D & R6 & 43.619 & -118.56 & & $\mathrm{X}$ \\
B163 & 3D & R6 & 43.619 & -118.56 & $\mathrm{X}$ & $\mathrm{X}$ \\
B165 & 3D & (R6) & 43.625 & -118.55 & $\mathrm{X}$ & $\mathrm{X}$ \\
B168 & 3D & (R6) & 43.627 & -118.55 & $\mathrm{X}$ & $\mathrm{X}$ \\
B171 & 3D & R6 & 43.628 & -118.55 & $\mathrm{X}$ & $\mathrm{X}$ \\
B172 & 3E & R8 & 43.629 & -118.55 & $\mathrm{X}$ & \\
B175 & 3D & R6 & 43.602 & -118.63 & $\mathrm{X}$ & $\mathrm{X}$ \\
B178 & 3E & R7 & 43.606 & -118.62 & $\mathrm{X}$ & $\mathrm{X}$ \\
B185 & 3A & R2 & 43.597 & -118.6 & $\mathrm{X}$ & $\mathrm{X}$ \\
B191 & 3F & RT & 43.599 & -118.6 & $\mathrm{X}$ & $\mathrm{X}$ \\
B352 & 3D & R6 & 43.619 & -118.56 & & $\mathrm{X}$ \\
B354 & 2B & R7 & 43.607 & -118.62 & & $\mathrm{X}$ \\
B355 & 2A & R6 & 43.602 & -118.62 & & $\mathrm{X}$ \\
B356 & b3B & Ba1 & 43.616 & -118.56 & & \\
\hline
\end{tabular}


Appendix B : Dooley Mountain Rhyolite Complex 
Appendix B-1 : Hand Sample Data

\begin{tabular}{|c|c|c|c|c|c|c|c|}
\hline $\begin{array}{l}\text { Sample } \\
\text { Number }\end{array}$ & Lat. & Long. & Color & Phenocrysts & $\begin{array}{r}\text { Size } \\
(\mathrm{mm})\end{array}$ & $\begin{array}{c}\text { Abundance } \\
(\%)\end{array}$ & Other details \\
\hline 28 & 44.570 & -117.83 & white/ tan & & & 0 & $\begin{array}{l}\text { includes } \\
\text { medium gray } \\
\text { clasts up to } \\
15 \mathrm{~cm} \text {, and vitric } \\
\text { white clasts }\end{array}$ \\
\hline 31 & 44.569 & -117.839 & pink & $\begin{array}{l}\text { feldspar, } \\
\text { quartz }\end{array}$ & 1 & 1 & flow banded \\
\hline 32 & 44.567 & -117.846 & white & & & 0 & \\
\hline $34 \mathrm{~A}$ & 44.564 & -117.849 & $\begin{array}{l}\text { light gray/ } \\
\text { pink }\end{array}$ & & & 0 & \multirow{6}{*}{$\begin{array}{l}\text { flow banded } \\
\text { breccia, white } \\
\text { clasts }<2 \mathrm{~cm} \\
\text { breccia, white } \\
\text { clasts }<1 \mathrm{~cm} \\
\text { breccia, white } \\
\text { clasts }<10 \mathrm{~cm}\end{array}$} \\
\hline $34 \mathrm{~B}$ & 44.564 & -117.849 & light gray & & & 0 & \\
\hline $34 \mathrm{C}$ & 44.564 & -117.849 & med gray & & & 0 & \\
\hline 35 & 44.562 & -117.847 & med gray & quartz & $<1$ & $<1$ & \\
\hline 36 & 44.562 & -117.848 & white & quartz & $<1$ & $<1$ & \\
\hline 37 & 44.561 & -117.848 & white & & & 0 & \\
\hline 38 & 44.506 & -117.846 & $\begin{array}{l}\text { medium/ } \\
\text { dark gray }\end{array}$ & feldspar & $<1$ & $<1$ & \multirow{3}{*}{$\begin{array}{l}\text { Basalt, } \\
\text { vesiculated } \\
\text { Vitric } \\
\text { altered } \\
\text { red/brown } \\
\text { phenocrysts } \\
\text { likely } \\
\text { amphibole }\end{array}$} \\
\hline $39 \mathrm{~A}$ & 44.506 & -117.846 & black & & & 0 & \\
\hline $39 B$ & 44.506 & -117.846 & $\begin{array}{l}\text { medium } \\
\text { gray/ pink }\end{array}$ & $\begin{array}{l}\text { feldspar, } \\
\text { amphibole }\end{array}$ & $<1,1$ & 1 & \\
\hline 40 & 44.559 & -117.847 & light gray & quartz & $<1$ & $<1$ & \\
\hline 41 & 44.559 & -117.847 & white & $\begin{array}{l}\text { feldspar, } \\
\text { quartz }\end{array}$ & $\begin{array}{l}<1, \\
<1\end{array}$ & $<1$ & \\
\hline 42 & 44.555 & -117.851 & white & & & 0 & \\
\hline 43 & 44.555 & -117.851 & $\begin{array}{l}\text { white/ } \\
\text { light gray }\end{array}$ & $\begin{array}{l}\text { feldspar, } \\
\text { quartz }\end{array}$ & $<1,1$ & 1 & \multirow{2}{*}{$\begin{array}{l}\text { breccia, white } \\
\text { clasts } \\
\text { breccia, white } \\
\text { clasts }\end{array}$} \\
\hline $44 \mathrm{~A}$ & 44.551 & -117.851 & light gray & & & 0 & \\
\hline $44 \mathrm{~B}$ & 44.551 & -117.851 & white & & & 0 & \\
\hline 45 & 44.549 & -117.850 & white & & & 0 & \\
\hline 46 & 44.549 & -117.849 & white & & & 0 & \\
\hline 47 & 44.546 & -117.851 & white & $\begin{array}{l}\text { feldspar, } \\
\text { quartz }\end{array}$ & $<1,1$ & 1 & \\
\hline 48 & 44.547 & -117.852 & white & $\begin{array}{c}\text { feldspar, } \\
\text { quartz }\end{array}$ & $<1,1$ & 1 & white clasts \\
\hline 49 & 44.539 & -117.844 & white & $\begin{array}{l}\text { feldspar, } \\
\text { quartz }\end{array}$ & $<1,1$ & 1 & \\
\hline 50 & 44.533 & -117.842 & black & & & 0 & vitric \\
\hline $51 \mathrm{~A}$ & 44.529 & -117.840 & black & & & 0 & $\begin{array}{l}\text { vitric, flow } \\
\text { banded glass }\end{array}$ \\
\hline
\end{tabular}




\begin{tabular}{|c|c|c|c|c|c|c|c|}
\hline $\begin{array}{l}\text { Sample } \\
\text { Number }\end{array}$ & Lat. & Long. & Color & $\begin{array}{c}\text { Phenocry } \\
\text { sts }\end{array}$ & $\begin{array}{r}\text { Size } \\
(\mathrm{mm})\end{array}$ & $\begin{array}{c}\text { Abundance } \\
(\%)\end{array}$ & Other details \\
\hline $51 \mathrm{~B}$ & 44.529 & -117.840 & $\begin{array}{l}\text { light/ medium } \\
\text { gray }\end{array}$ & & & 0 & \\
\hline 52 & 44.522 & -117.842 & dark gray & feldspar & 2 & 30 & Basalt \\
\hline 53 & 44.516 & -117.844 & white/ pink & feldspar & 1 & 1 & \\
\hline 200 & 44.580 & -117.839 & $\begin{array}{l}\text { white/ light } \\
\text { gray }\end{array}$ & & & 0 & \\
\hline 201 & 44.585 & -117.843 & black & feldspar & 3 & 10 & \\
\hline 202 & 44.585 & -117.845 & $\begin{array}{l}\text { light/ medium } \\
\text { gray }\end{array}$ & feldspar & 2 & 5 & \\
\hline 204 & 44.585 & -117.848 & light gray & & & 0 & $\begin{array}{l}\text { Tuff dike, } \\
\text { pumaceous, } \\
\text { white lithics }\end{array}$ \\
\hline 205 & 44.586 & -117.850 & $\begin{array}{l}\text { medium/ dark } \\
\text { gray }\end{array}$ & feldspar & 2 & 3 & \\
\hline 206 & 44.589 & -117.846 & black & feldspar & 3 & 10 & vitric \\
\hline 207 & 44.589 & -117.850 & whtie & $\begin{array}{l}\text { feldspar, } \\
\text { quartz }\end{array}$ & 3,1 & 5 & \\
\hline $208 \mathrm{~A}$ & 44.612 & -117.861 & light gray & feldspar & $<1$ & 1 & $\begin{array}{l}\text { ashy, black } \\
\text { speckles }\end{array}$ \\
\hline $208 \mathrm{~B}$ & 44.612 & -117.861 & $\begin{array}{l}\text { light/ medium } \\
\text { gray }\end{array}$ & feldspar & 1 & 1 & $\begin{array}{l}\text { flow banded } \\
\text { blocks within } \\
\text { ashy matrix of } \\
\text { 208A }\end{array}$ \\
\hline 209 & 44.507 & -117.845 & medium gray & feldspar & $<1$ & $<1$ & \\
\hline 210 & 44.508 & -117.845 & $\begin{array}{l}\text { medium gray/ } \\
\text { pink }\end{array}$ & feldspar & 1 & $<1$ & \\
\hline 211 & 44.508 & -117.845 & $\begin{array}{l}\text { light gray/ } \\
\text { green }\end{array}$ & & & 0 & vitric, perlitic \\
\hline 212 & 44.510 & -117.846 & $\begin{array}{l}\text { light/ medium } \\
\text { gray }\end{array}$ & feldspar & 3 & 5 & vitric \\
\hline 213 & 44.510 & -117.847 & light gray & $\begin{array}{l}\text { feldspar, } \\
\text { quartz }\end{array}$ & 2,1 & 3 & \\
\hline 214 & 44.512 & -117.845 & light gray & & & 0 & vitric \\
\hline 215 & 44.514 & -117.846 & $\begin{array}{l}\text { light gray/ } \\
\text { pink }\end{array}$ & feldspar & 2 & 1 & \\
\hline 216 & 44.515 & -117.844 & $\begin{array}{l}\text { light gray/ } \\
\text { pink }\end{array}$ & feldspar & 1 & 1 & \\
\hline 217 & 44.530 & -117.838 & light gray & & & 0 & \\
\hline 218 & 44.532 & -117.837 & light gray & & & 0 & $\begin{array}{l}\text { vitric, black } \\
\text { speckles }\end{array}$ \\
\hline 219 & 44.532 & -117.837 & light gray/tan & feldspar & 2 & 2 & \\
\hline 220 & 44.533 & -117.837 & medium gray & feldspar & 3 & 15 & \\
\hline 221 & 44.560 & -117.841 & white & & & 0 & \\
\hline
\end{tabular}




\begin{tabular}{|c|c|c|c|c|c|c|c|}
\hline $\begin{array}{l}\text { Sample } \\
\text { Number }\end{array}$ & Lat. & Long. & Color & Phenocrysts & $\begin{array}{r}\text { Size } \\
(\mathrm{mm})\end{array}$ & $\begin{array}{c}\text { Abundance } \\
(\%)\end{array}$ & Other details \\
\hline 222 & 44.556 & -117.828 & $\begin{array}{l}\text { white/ } \\
\text { light gray }\end{array}$ & & & 0 & \\
\hline 223 & 44.575 & -117.821 & $\begin{array}{l}\text { light gray/ } \\
\text { pink }\end{array}$ & & & 0 & \\
\hline 224 & 44.578 & -117.819 & $\begin{array}{l}\text { medium } \\
\text { gray }\end{array}$ & $\begin{array}{l}\text { feldspar, } \\
\text { amphibole }\end{array}$ & 3,2 & 10 & $\begin{array}{l}\text { altered red/brown } \\
\text { phenocrysts likely } \\
\text { amphibole }\end{array}$ \\
\hline 225 & 44.576 & -117.822 & black & & & 0 & $\begin{array}{l}\text { obsidian, } \\
\text { weathering to } \\
\text { shards }\end{array}$ \\
\hline 226 & 44.568 & -117.849 & $\begin{array}{l}\text { medium/ } \\
\text { dark gray }\end{array}$ & quartz & $<1$ & 1 & spherulites to $2 \mathrm{~cm}$ \\
\hline 227 & 44.562 & -117.852 & white & & & 0 & \\
\hline 228 & 44.563 & -117.860 & white & & & 0 & $\begin{array}{l}\text { breccia, white } \\
\text { clasts of similar } \\
\text { material, dark } \\
\text { gray clasts with } \\
8 \% 3 \mathrm{~mm} \text { feldspar }\end{array}$ \\
\hline 229 & 44.560 & -117.858 & $\begin{array}{l}\text { light/ } \\
\text { medium } \\
\text { gray }\end{array}$ & feldspar & 3 & 3 & \\
\hline 230 & 44.558 & -117.849 & light gray & & & 0 & white clasts \\
\hline 231 & 44.578 & -117.860 & light gray & & & 0 & $\begin{array}{l}\text { white clasts and } \\
\text { spherulites }\end{array}$ \\
\hline 232 & 44.540 & -117.861 & $\tan$ & & & 0 & $\begin{array}{l}\text { microlite } \\
\text { groundmass, } \\
\text { vesiculated }\end{array}$ \\
\hline 233 & 44.535 & -117.859 & $\begin{array}{l}\text { light gray/ } \\
\text { lavender }\end{array}$ & & & 0 & flow banded clasts \\
\hline 234 & 44.533 & -117.856 & black & feldspar & 3 & 5 & vitric \\
\hline 235 & 44.547 & -117.866 & dark gray & $\begin{array}{l}\text { feldspar, } \\
\text { amphibole }\end{array}$ & 2,1 & 3 & $\begin{array}{l}\text { altered red/ } \\
\text { brown } \\
\text { phenocrysts likely } \\
\text { amphibole }\end{array}$ \\
\hline $236 \mathrm{~A}$ & 44.525 & -117.861 & $\begin{array}{l}\text { red/ } \\
\text { brown }\end{array}$ & & & 0 & \\
\hline $236 \mathrm{~B}$ & 44.525 & -117.861 & $\begin{array}{c}\text { tan/ } \\
\text { orange }\end{array}$ & & & 0 & \\
\hline 237 & 44.527 & -117.862 & black & & & 0 & obsidian \\
\hline 238 & 44.575 & -117.822 & black & & & 0 & obsidian \\
\hline 239 & 44.579 & -117.819 & $\begin{array}{l}\text { medium } \\
\text { gray }\end{array}$ & $\begin{array}{l}\text { feldspar, } \\
\text { amphibole }\end{array}$ & 2,1 & 5 & \\
\hline 240 & 44.580 & -117.812 & $\begin{array}{l}\text { medium } \\
\text { gray/pink }\end{array}$ & feldspar & 3 & 10 & \\
\hline 241 & 44.580 & -117.811 & black & feldspar & 3 & 5 & vitric \\
\hline
\end{tabular}




\begin{tabular}{|c|c|c|c|c|c|c|c|}
\hline $\begin{array}{l}\text { Sample } \\
\text { Number }\end{array}$ & Lat. & Long. & Color & Phenocrysts & $\begin{array}{r}\text { Size } \\
(\mathrm{mm})\end{array}$ & $\begin{array}{c}\text { Abundance } \\
(\%)\end{array}$ & Other details \\
\hline 244 & 44.607 & -117.801 & light gray & & & 0 & flow banded \\
\hline $246 \mathrm{~A}$ & 44.613 & -117.799 & light gray & feldspar & 2 & 2 & $\begin{array}{l}\text { Tuff, } 5 \% \text { dark } \\
\text { gray lithics } \\
<2 \mathrm{~mm}\end{array}$ \\
\hline 246B & 44.613 & -117.799 & light tan & feldspar & 2 & 1 & $\begin{array}{l}\text { Tuff, } 5 \% \text { dark } \\
\text { gray lithics } \\
<2 \mathrm{~mm}\end{array}$ \\
\hline 247 & 44.585 & -117.795 & light gray & & & 0 & ashy \\
\hline 249 & 44.547 & -117.831 & white/ pink & & & 0 & \\
\hline 250 & 44.544 & -117.821 & black & feldspar & 3 & 10 & vitric \\
\hline 251 & 44.545 & -117.820 & white & $\begin{array}{c}\text { feldspar,qua } \\
\text { rtz }\end{array}$ & 1,1 & 1 & \\
\hline 252 & 44.551 & -117.818 & black & feldspar & 3 & 10 & \\
\hline 253 & 44.573 & -117.812 & white/ pink & feldspar & 3 & 3 & \\
\hline 254 & 44.526 & -117.802 & $\begin{array}{c}\text { medium } \\
\text { gray }\end{array}$ & & & 0 & $\begin{array}{l}\text { Burnt River } \\
\text { schist }\end{array}$ \\
\hline $255 \mathrm{~A}$ & 44.527 & -117.802 & dark gray & $\begin{array}{l}\text { feldspar, } \\
\text { olivine }\end{array}$ & 2,1 & 3 & Basalt \\
\hline $255 \mathrm{~B}$ & 44.527 & -117.802 & $\begin{array}{l}\text { dark gray/ } \\
\text { black }\end{array}$ & feldspar & 10 & 15 & Basalt \\
\hline 256 & 44.527 & -117.802 & $\begin{array}{c}\text { Black/ dark } \\
\text { gray }\end{array}$ & feldspar & 2 & 2 & $\begin{array}{l}\text { Welded tuff, } \\
\text { vitric, lithics } \\
1 \mathrm{~cm}, \\
\text { pumice/fiame } \\
\text { upto } 5 \mathrm{~cm}\end{array}$ \\
\hline 258 & 44.528 & -117.802 & $\begin{array}{l}\text { medium } \\
\text { gray }\end{array}$ & & & 0 & vitric \\
\hline 259 & 44.529 & -117.802 & $\begin{array}{l}\text { light gray/ } \\
\text { medium } \\
\text { gray }\end{array}$ & & & 0 & \\
\hline 260 & 44.522 & -117.842 & dark gray & $\begin{array}{l}\text { feldspar, } \\
\text { olivine }\end{array}$ & 4,1 & 15 & Basalt \\
\hline 261 & 44.504 & -117.844 & dark gray & $\begin{array}{l}\text { feldspar, } \\
\text { olivine }\end{array}$ & 2,3 & 5 & $\begin{array}{l}\text { Basalt, } \\
\text { fragments of } \\
\text { Burnt River } \\
\text { schist }\end{array}$ \\
\hline 262 & 44.508 & -117.808 & $\begin{array}{l}\text { light gray/ } \\
\text { medium } \\
\text { gray }\end{array}$ & feldspar & 1 & 1 & \\
\hline 263 & 44.510 & -117.811 & $\begin{array}{l}\text { medium } \\
\text { gray }\end{array}$ & $\begin{array}{c}\text { felspar, } \\
\text { amphibole }\end{array}$ & 3,2 & 5 & $\begin{array}{l}\text { contains } \\
\text { altered } \\
\text { red/brown } \\
\text { phenocrysts } \\
\text { likely } \\
\text { amphibole }\end{array}$ \\
\hline
\end{tabular}




\begin{tabular}{|c|c|c|c|c|c|c|c|}
\hline $\begin{array}{l}\text { Sample } \\
\text { Number }\end{array}$ & Lat. & Long. & Color & Phenocrysts & $\begin{array}{l}\text { Size } \\
(\mathrm{mm})\end{array}$ & $\begin{array}{c}\text { Abundance } \\
(\%)\end{array}$ & Other details \\
\hline 264 & 44.510 & -117.811 & light gray & $\begin{array}{l}\text { feldspar, } \\
\text { amphibole }\end{array}$ & 3,1 & 5 & $\begin{array}{l}\text { altered } \\
\text { red/brown } \\
\text { phenocrysts } \\
\text { likely amphibole }\end{array}$ \\
\hline $265 \mathrm{~A}$ & 44.511 & -117.813 & black & $\begin{array}{l}\text { feldspar, } \\
\text { amphibole }\end{array}$ & 3,2 & 5 & $\begin{array}{l}\text { top breccia, } \\
\text { contains altered } \\
\text { red/brown } \\
\text { phenocrysts } \\
\text { likely amphibole }\end{array}$ \\
\hline 265Ash & 44.511 & -117.813 & $\begin{array}{l}\text { medium } \\
\text { gray/ } \\
\text { brown }\end{array}$ & feldspar & 1 & 1 & $\begin{array}{l}\text { ash fall, contains } \\
2 \mathrm{~cm} \text { obsidian } \\
\text { clasts }\end{array}$ \\
\hline 265Lapilli & 44.511 & -117.813 & $\begin{array}{l}\text { medium } \\
\text { gray/ } \\
\text { brown }\end{array}$ & feldspar & 1 & 1 & $\begin{array}{l}\text { lapilli fall, } \\
\text { contains pumice } \\
\text { to } 2 \mathrm{~cm} \text { and } \\
\text { obsidian to } 5 \mathrm{~mm}\end{array}$ \\
\hline 265B & 44.511 & -117.813 & $\begin{array}{l}\text { medium } \\
\text { gray }\end{array}$ & feldspar & 3 & 1 & bottom breccia \\
\hline 266 & 44.511 & -117.815 & $\begin{array}{l}\text { light gray/ } \\
\text { pink }\end{array}$ & feldspar & 2 & 5 & \\
\hline 267 & 44.525 & -117.815 & white & & & 0 & $\begin{array}{l}\text { microlite } \\
\text { groundmass }\end{array}$ \\
\hline 268 & 44.525 & -117.815 & $\begin{array}{l}\text { medium } \\
\text { gray }\end{array}$ & & & 0 & \\
\hline 269 & 44.525 & -117.815 & $\tan$ & feldspar & 1 & 1 & $\begin{array}{l}\text { tuff, lithics up to } \\
4 \mathrm{~mm}\end{array}$ \\
\hline 270 & 44.525 & -117.815 & dark gray & feldspar & 2 & 1 & $\begin{array}{l}\text { tuff, lithics up to } \\
5 \mathrm{~mm} \text {, fiamme up } \\
\text { to } 3 \mathrm{~cm}\end{array}$ \\
\hline 271 & 44.516 & -117.821 & dark gray & feldspar & 3 & 10 & vitric \\
\hline 272 & 44.556 & -117.919 & light gray & feldspar & 1 & 1 & \\
\hline $273 \mathrm{~A}$ & 44.557 & -117.918 & $\begin{array}{l}\text { medium } \\
\text { gray }\end{array}$ & feldspar & 3 & 10 & \\
\hline 273B & 44.557 & -117.918 & $\begin{array}{l}\text { brown } \\
\text { gray }\end{array}$ & & & 0 & $\begin{array}{l}\text { tuff, pumice up } \\
\text { to } 2 \mathrm{~cm} \text { and } \\
\text { obsidian clasts } \\
\text { up to } 2 \mathrm{~cm}\end{array}$ \\
\hline 274 & 44.554 & -117.916 & dark gray & feldspar & 2 & 5 & $\begin{array}{l}\text { tuff, pumice } 2 \mathrm{~cm} \\
\text { obsidian } 2 \mathrm{~cm}\end{array}$ \\
\hline 276 & 44.506 & -117.913 & light gray & feldspar & 1 & 2 & $\begin{array}{l}\text { tuff, lithics up to } \\
1 \mathrm{~cm}\end{array}$ \\
\hline
\end{tabular}




\section{Appendix B-2 : Petrographic Data}

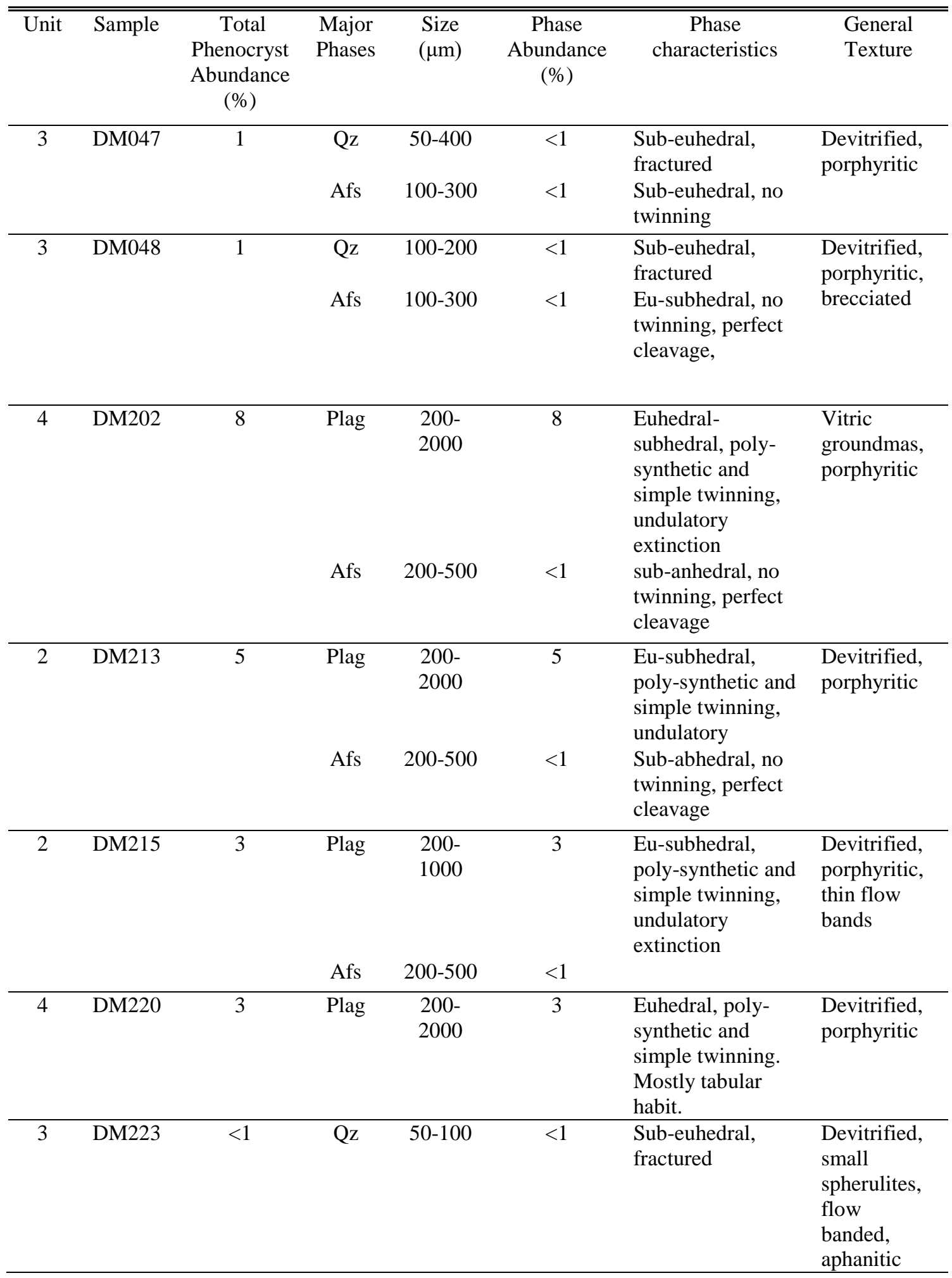




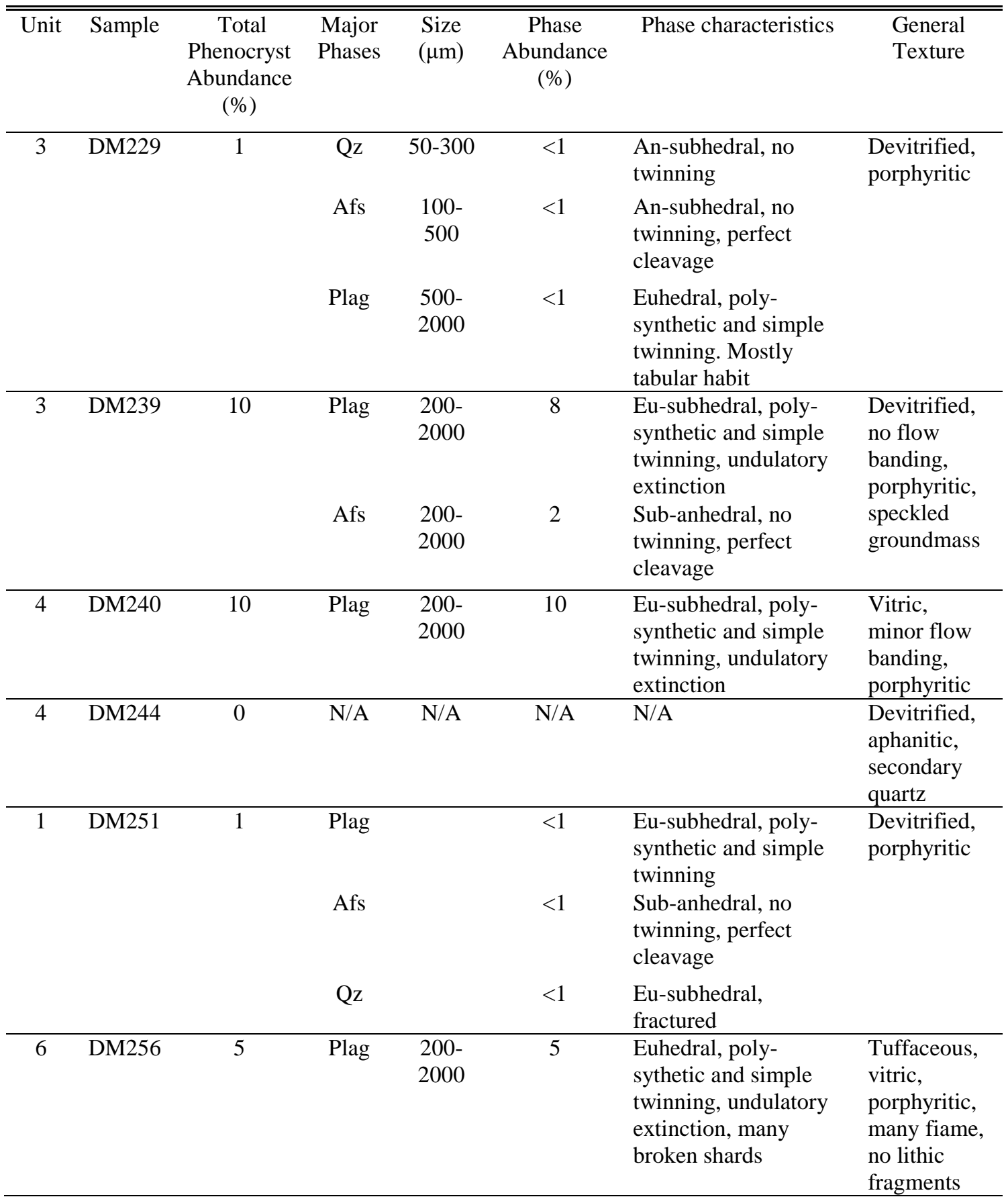




\begin{tabular}{|c|c|c|c|c|c|c|c|}
\hline Unit & Sample & $\begin{array}{c}\text { Total } \\
\text { Phenocryst } \\
\text { Abundance } \\
\quad \%)\end{array}$ & $\begin{array}{l}\text { Major } \\
\text { Phases }\end{array}$ & $\begin{array}{l}\text { Size } \\
(\mu \mathrm{m})\end{array}$ & $\begin{array}{c}\text { Phase } \\
\text { Abundance } \\
(\%)\end{array}$ & Phase characteristics & $\begin{array}{l}\text { General } \\
\text { Texture }\end{array}$ \\
\hline 1 & DM258 & 0 & N/A & N/A & N/A & N/A & $\begin{array}{l}\text { Vitric, } \\
\text { minor } \\
\text { perlitic } \\
\text { texture, } \\
\text { aphanitic }\end{array}$ \\
\hline 1 & DM259 & 0 & N/A & N/A & N/A & N/A & $\begin{array}{l}\text { Devitrified, } \\
\text { spherulitic } \\
\text { groundmass, } \\
\text { flow } \\
\text { banded, } \\
\text { aphanitic }\end{array}$ \\
\hline \multirow[t]{2}{*}{3} & DM264 & 5 & Plag & $\begin{array}{c}50- \\
2000\end{array}$ & 4 & $\begin{array}{l}\text { Eu-subhedral, poly- } \\
\text { synthetic and simple } \\
\text { twinning, undulatory } \\
\text { extinction }\end{array}$ & $\begin{array}{l}\text { Devitrified, } \\
\text { porphyritic, } \\
\text { minor flow } \\
\text { banding }\end{array}$ \\
\hline & & & Amp & $\begin{array}{l}200- \\
1000\end{array}$ & 1 & $\begin{array}{l}\text { Eu-subhedral, } \\
\text { prismatic, dark brown }\end{array}$ & \\
\hline 5 & DM269 & 3 & Plag & $\begin{array}{c}50- \\
1000\end{array}$ & & $\begin{array}{l}\text { Eu-subhedral, poly- } \\
\text { synthetic and simple } \\
\text { twinning, some } \\
\text { broken shards }\end{array}$ & $\begin{array}{l}\text { Tuffaceous, } \\
\text { glass shards, } \\
\text { lithic } \\
\text { fragments }\end{array}$ \\
\hline
\end{tabular}




\section{Appendix B-3 : Geochemical Data}

\section{B-3a : XRF results}

\begin{tabular}{|c|c|c|c|c|c|c|c|c|}
\hline \multirow{2}{*}{$\begin{array}{l}\text { Sample } \\
\text { ID } \\
\end{array}$} & \multicolumn{3}{|c|}{ DM044 } & \multirow[b]{2}{*}{ DM202 } & \multirow[b]{2}{*}{ DM220 } & \multirow[b]{2}{*}{ DM223 } & \multirow[b]{2}{*}{ DM234 } & \multirow[b]{2}{*}{ DM235 } \\
\hline & DM038 & B & DM048 & & & & & \\
\hline \multirow[t]{2}{*}{ Unit } & B2 & R4 & R4 & R3 & R3 & $\mathrm{R} 4$ & $\mathrm{R} 2$ & R2 \\
\hline & \multicolumn{8}{|c|}{ This Study } \\
\hline \multicolumn{9}{|c|}{ XRF - wt\% (normalized) } \\
\hline $\mathrm{SiO} 2$ & 53.58 & 83.48 & 81.03 & 76.55 & 76.37 & 77.43 & 77.65 & 76.72 \\
\hline $\mathrm{TiO} 2$ & 0.87 & 0.14 & 0.19 & 0.34 & 0.28 & 0.16 & 0.12 & 0.11 \\
\hline $\mathrm{A} 12 \mathrm{O} 3$ & 17.25 & 12.38 & 14.11 & 13.47 & 13.50 & 12.83 & 13.37 & 13.00 \\
\hline $\mathrm{FeO} *$ & 7.56 & 0.64 & 0.50 & 0.62 & 1.42 & 1.23 & 1.08 & 1.33 \\
\hline $\mathrm{MnO}$ & 0.135 & 0.008 & 0.003 & 0.004 & 0.009 & 0.008 & 0.032 & 0.031 \\
\hline $\mathrm{MgO}$ & 6.70 & 0.08 & 0.04 & 0.01 & 0.03 & 0.01 & 0.03 & 0.05 \\
\hline $\mathrm{CaO}$ & 10.38 & 0.03 & 0.03 & 1.32 & 1.40 & 0.80 & 1.21 & 0.92 \\
\hline $\mathrm{Na} 2 \mathrm{O}$ & 2.80 & 0.01 & 0.20 & 3.87 & 3.28 & 3.78 & 2.38 & 3.66 \\
\hline $\mathrm{K} 2 \mathrm{O}$ & 0.50 & 3.22 & 3.88 & 3.80 & 3.69 & 3.74 & 4.10 & 4.16 \\
\hline $\mathrm{P} 2 \mathrm{O} 5$ & 0.228 & 0.013 & 0.014 & 0.017 & 0.023 & 0.016 & 0.015 & 0.014 \\
\hline \multicolumn{9}{|c|}{ XRF - ppm (unnormalized): } \\
\hline $\mathrm{Ni}$ & 62 & 0 & 3 & 2 & 2 & 1 & 1 & 4 \\
\hline $\mathrm{Cr}$ & 229 & 3 & 3 & 3 & 2 & 3 & 3 & 16 \\
\hline $\mathrm{Sc}$ & 32 & 5 & 6 & 8 & 9 & 3 & 4 & 4 \\
\hline $\mathrm{V}$ & 216 & 3 & 5 & 6 & 8 & 4 & 4 & 4 \\
\hline $\mathrm{Ba}$ & 339 & 2725 & 1523 & 1840 & 1331 & 1516 & 1705 & 1677 \\
\hline $\mathrm{Rb}$ & 8 & 86 & 101 & 97 & 89 & 95 & 116 & 98 \\
\hline $\mathrm{Sr}$ & 386 & 9 & 27 & 169 & 137 & 108 & 123 & 96 \\
\hline $\mathrm{Zr}$ & 85 & 222 & 326 & 382 & 346 & 284 & 173 & 180 \\
\hline $\mathrm{Y}$ & 24 & 55 & 39 & 52 & 55 & 51 & 36 & 30 \\
\hline $\mathrm{Nb}$ & 4.7 & 14.0 & 16.0 & 16.1 & 14.1 & 15.2 & 9.4 & 10.2 \\
\hline $\mathrm{Ga}$ & 16 & 20 & 21 & 21 & 20 & 21 & 16 & 18 \\
\hline $\mathrm{Cu}$ & 27 & 0 & 0 & 6 & 6 & 3 & 2 & 4 \\
\hline $\mathrm{Zn}$ & 76 & 2 & 13 & 82 & 107 & 90 & 48 & 68 \\
\hline $\mathrm{Pb}$ & 1 & 3 & 2 & 15 & 15 & 16 & 17 & 17 \\
\hline $\mathrm{La}$ & 11 & 37 & 39 & 45 & 38 & 60 & 40 & 37 \\
\hline $\mathrm{Ce}$ & 24 & 60 & 82 & 86 & 76 & 66 & 75 & 69 \\
\hline Th & 1 & 10 & 9 & 9 & 7 & 8 & 8 & 9 \\
\hline $\mathrm{Nd}$ & 13 & 31 & 38 & 46 & 39 & 65 & 30 & 31 \\
\hline $\mathrm{U}$ & 1 & 3 & 3 & 3 & 2 & 3 & 3 & 2 \\
\hline
\end{tabular}




\begin{tabular}{|c|c|c|c|c|c|c|c|c|}
\hline $\begin{array}{l}\text { Sample } \\
\text { ID }\end{array}$ & DM238 & DM240 & DM241 & $\begin{array}{c}\text { DM246 } \\
\text { A }\end{array}$ & DM247 & DM250 & $\begin{array}{c}\text { DM255 } \\
\text { A }\end{array}$ & $\begin{array}{c}\text { DM255 } \\
\text { B }\end{array}$ \\
\hline & $\mathrm{R} 4$ & R3 & R3 & $\mathrm{T} 1$ & $\mathrm{R} 1$ & $\mathrm{R} 3$ & B3 & $\mathrm{B} 1$ \\
\hline & \multicolumn{8}{|c|}{ This Study } \\
\hline \multicolumn{9}{|c|}{ XRF - wt\% (normalized) } \\
\hline $\mathrm{SiO} 2$ & 76.52 & 75.09 & 74.13 & 80.23 & 76.02 & 74.62 & 49.89 & 50.02 \\
\hline $\mathrm{TiO} 2$ & 0.15 & 0.29 & 0.28 & 0.19 & 0.06 & 0.28 & 1.67 & 0.99 \\
\hline $\mathrm{A} 12 \mathrm{O} 3$ & 12.42 & 13.86 & 13.34 & 10.97 & 14.06 & 13.73 & 15.07 & 17.18 \\
\hline $\mathrm{FeO} *$ & 2.00 & 1.33 & 2.73 & 1.26 & 0.83 & 2.10 & 8.77 & 9.97 \\
\hline $\mathrm{MnO}$ & 0.037 & 0.018 & 0.045 & 0.007 & 0.036 & 0.023 & 0.174 & 0.173 \\
\hline $\mathrm{MgO}$ & 0.04 & 0.04 & 0.19 & 0.10 & 0.09 & 0.07 & 8.27 & 7.53 \\
\hline $\mathrm{CaO}$ & 1.12 & 1.50 & 1.59 & 0.45 & 0.70 & 1.49 & 9.60 & 11.00 \\
\hline $\mathrm{Na} 2 \mathrm{O}$ & 4.02 & 4.11 & 3.84 & 3.45 & 3.25 & 3.57 & 4.32 & 2.50 \\
\hline $\mathrm{K} 2 \mathrm{O}$ & 3.67 & 3.73 & 3.81 & 3.32 & 4.95 & 4.07 & 1.37 & 0.44 \\
\hline $\mathrm{P} 2 \mathrm{O} 5$ & 0.013 & 0.046 & 0.047 & 0.021 & 0.015 & 0.036 & 0.869 & 0.178 \\
\hline \multicolumn{9}{|c|}{ XRF - ppm (unnormalized): } \\
\hline $\mathrm{Ni}$ & 1 & 3 & 2 & 2 & 2 & 3 & 188 & 57 \\
\hline $\mathrm{Cr}$ & 3 & 8 & 3 & 5 & 3 & 3 & 285 & 88 \\
\hline $\mathrm{Sc}$ & 4 & 8 & 7 & 4 & 4 & 7 & 21 & 32 \\
\hline $\mathrm{V}$ & 3 & 13 & 12 & 15 & 3 & 10 & 210 & 241 \\
\hline $\mathrm{Ba}$ & 1485 & 1343 & 1279 & 1201 & 667 & 1286 & 920 & 231 \\
\hline $\mathrm{Rb}$ & 94 & 94 & 90 & 67 & 121 & 92 & 19 & 8 \\
\hline $\mathrm{Sr}$ & 113 & 149 & 134 & 38 & 39 & 144 & 1626 & 314 \\
\hline $\mathrm{Zr}$ & 274 & 319 & 297 & 378 & 85 & 298 & 172 & 60 \\
\hline $\mathrm{Y}$ & 59 & 49 & 46 & 82 & 34 & 48 & 20 & 24 \\
\hline $\mathrm{Nb}$ & 15.1 & 13.8 & 12.9 & 21.3 & 10.5 & 12.5 & 13.5 & 3.6 \\
\hline $\mathrm{Ga}$ & 20 & 21 & 19 & 18 & 16 & 20 & 20 & 16 \\
\hline $\mathrm{Cu}$ & 3 & 4 & 4 & 3 & 1 & 6 & 64 & 35 \\
\hline $\mathrm{Zn}$ & 119 & 109 & 83 & 124 & 38 & 202 & 113 & 92 \\
\hline $\mathrm{Pb}$ & 15 & 16 & 14 & 14 & 18 & 14 & 8 & 1 \\
\hline $\mathrm{La}$ & 40 & 39 & 37 & 36 & 27 & 37 & 44 & 7 \\
\hline $\mathrm{Ce}$ & 74 & 69 & 65 & 68 & 46 & 68 & 93 & 18 \\
\hline $\mathrm{Th}$ & 7 & 8 & 8 & 7 & 10 & 8 & 5 & 1 \\
\hline $\mathrm{Nd}$ & 40 & 33 & 33 & 38 & 20 & 33 & 48 & 11 \\
\hline $\mathrm{U}$ & 4 & 3 & 3 & 4 & 4 & 3 & 3 & 0 \\
\hline
\end{tabular}




\begin{tabular}{|c|c|c|c|c|c|c|c|c|}
\hline \multirow{2}{*}{$\begin{array}{l}\text { Sample } \\
\text { ID }\end{array}$} & \multirow[b]{2}{*}{ DM256 } & \multirow[b]{2}{*}{ DM258 } & \multirow[b]{2}{*}{ DM260 } & \multirow[b]{2}{*}{ DM264 } & \multirow{2}{*}{$\begin{array}{c}\text { DM265 } \\
\text { A }\end{array}$} & \multicolumn{3}{|c|}{ DM265 } \\
\hline & & & & & & DM265 & $\mathrm{B}$ & DM269 \\
\hline & $\mathrm{T} 3$ & $\mathrm{R} 1$ & $\mathrm{~B} 1$ & $\mathrm{R} 4$ & $\mathrm{R} 4$ & $\mathrm{R} 4$ & $\mathrm{R} 4$ & $\mathrm{~T} 2$ \\
\hline & \multicolumn{8}{|c|}{ This Study } \\
\hline \multicolumn{9}{|c|}{ XRF - wt\% (normalized) } \\
\hline $\mathrm{SiO} 2$ & 69.65 & 76.69 & 50.63 & 75.65 & 75.69 & 73.97 & 75.65 & 76.20 \\
\hline $\mathrm{TiO} 2$ & 0.57 & 0.05 & 0.95 & 0.19 & 0.19 & 0.21 & 0.17 & 0.28 \\
\hline $\mathrm{A} 12 \mathrm{O} 3$ & 14.18 & 13.59 & 17.68 & 13.15 & 12.78 & 13.25 & 12.71 & 12.48 \\
\hline $\mathrm{FeO}^{*}$ & 4.81 & 0.95 & 11.22 & 2.21 & 2.18 & 3.09 & 2.06 & 2.86 \\
\hline $\mathrm{MnO}$ & 0.095 & 0.044 & 0.245 & 0.012 & 0.031 & 0.039 & 0.029 & 0.023 \\
\hline $\mathrm{MgO}$ & 0.40 & 0.04 & 4.62 & 0.07 & 0.11 & 0.23 & 0.11 & 0.31 \\
\hline $\mathrm{CaO}$ & 2.41 & 0.68 & 11.63 & 0.97 & 1.09 & 1.37 & 1.35 & 0.76 \\
\hline $\mathrm{Na} 2 \mathrm{O}$ & 3.30 & 3.12 & 2.58 & 3.72 & 3.26 & 3.19 & 3.35 & 3.05 \\
\hline $\mathrm{K} 2 \mathrm{O}$ & 4.41 & 4.83 & 0.29 & 3.99 & 4.65 & 4.61 & 4.56 & 4.00 \\
\hline $\mathrm{P} 2 \mathrm{O} 5$ & 0.170 & 0.013 & 0.142 & 0.029 & 0.024 & 0.051 & 0.025 & 0.034 \\
\hline \multicolumn{9}{|c|}{ XRF - ppm (unnormalized): } \\
\hline $\mathrm{Ni}$ & 4 & 2 & 48 & 4 & 2 & 2 & 1 & 4 \\
\hline $\mathrm{Cr}$ & 3 & 2 & 88 & 3 & 2 & 6 & 2 & 3 \\
\hline $\mathrm{Sc}$ & 12 & 4 & 33 & 5 & 6 & 4 & 3 & 5 \\
\hline V & 34 & 2 & 239 & 8 & 7 & 5 & 6 & 14 \\
\hline $\mathrm{Ba}$ & 1063 & 591 & 173 & 1419 & 1354 & 1395 & 1508 & 1344 \\
\hline $\mathrm{Rb}$ & 73 & 125 & 6 & 103 & 101 & 103 & 102 & 64 \\
\hline $\mathrm{Sr}$ & 189 & 34 & 251 & 101 & 116 & 100 & 105 & 86 \\
\hline $\mathrm{Zr}$ & 299 & 76 & 51 & 270 & 271 & 264 & 238 & 358 \\
\hline $\mathrm{Y}$ & 71 & 36 & 23 & 38 & 51 & 47 & 51 & 61 \\
\hline $\mathrm{Nb}$ & 13.1 & 9.8 & 2.9 & 13.7 & 14.0 & 13.2 & 13.3 & 20.8 \\
\hline $\mathrm{Ga}$ & 20 & 17 & 17 & 19 & 20 & 19 & 19 & 20 \\
\hline $\mathrm{Cu}$ & 3 & 0 & 35 & 4 & 6 & 4 & 3 & 2 \\
\hline $\mathrm{Zn}$ & 162 & 40 & 86 & 72 & 101 & 83 & 74 & 120 \\
\hline $\mathrm{Pb}$ & 12 & 17 & 2 & 15 & 14 & 14 & 14 & 15 \\
\hline $\mathrm{La}$ & 32 & 23 & 9 & 35 & 40 & 37 & 37 & 39 \\
\hline $\mathrm{Ce}$ & 62 & 44 & 16 & 54 & 75 & 73 & 74 & 70 \\
\hline $\mathrm{Th}$ & 6 & 9 & 1 & 8 & 9 & 7 & 8 & 6 \\
\hline $\mathrm{Nd}$ & 37 & 18 & 10 & 30 & 37 & 35 & 35 & 36 \\
\hline $\mathrm{U}$ & 3 & 3 & 0 & 2 & 5 & 3 & 3 & 3 \\
\hline
\end{tabular}




\begin{tabular}{|c|c|c|c|c|c|c|}
\hline Sample ID & DM273A & DR2 & DR4 & $\begin{array}{l}\text { MS-11- } \\
\text { 22DR }\end{array}$ & EJ-23A & EJ-23B \\
\hline & $\mathrm{R} 4$ & R3 & R1 & $\mathrm{R} 4$ & R2 & R1 \\
\hline & $\begin{array}{l}\text { This } \\
\text { Study }\end{array}$ & & Streck & & Hess & 014) \\
\hline \multicolumn{7}{|c|}{$\begin{array}{l}\text { XRF - wt\% } \\
\text { (normalized) }\end{array}$} \\
\hline $\mathrm{SiO} 2$ & 75.89 & 73.91 & 76.44 & 76.84 & 76.72 & 76.90 \\
\hline $\mathrm{TiO} 2$ & 0.20 & 0.33 & 0.05 & 0.17 & 0.12 & 0.05 \\
\hline $\mathrm{Al} 2 \mathrm{O} 3$ & 13.76 & 14.11 & 13.46 & 13.90 & 13.03 & 13.34 \\
\hline $\mathrm{FeO} *$ & 1.27 & 2.08 & 0.84 & 1.31 & 1.38 & 1.17 \\
\hline $\mathrm{MnO}$ & 0.023 & 0.037 & 0.042 & 0.027 & 0.033 & 0.044 \\
\hline $\mathrm{MgO}$ & 0.01 & 0.03 & 0.03 & 0.06 & 0.03 & 0.03 \\
\hline $\mathrm{CaO}$ & 1.34 & 2.08 & 0.68 & 0.84 & 1.05 & 0.69 \\
\hline $\mathrm{Na} 2 \mathrm{O}$ & 3.24 & 3.78 & 3.18 & 2.57 & 3.12 & 2.90 \\
\hline $\mathrm{K} 2 \mathrm{O}$ & 4.26 & 3.62 & 5.26 & 4.26 & 4.50 & 4.86 \\
\hline $\mathrm{P} 2 \mathrm{O} 5$ & 0.012 & 0.032 & 0.016 & 0.020 & 0.013 & 0.015 \\
\hline \multicolumn{7}{|c|}{ XRF - ppm (unnormalized): } \\
\hline $\mathrm{Ni}$ & 2 & 0 & 0 & 1 & 0 & 0 \\
\hline $\mathrm{Cr}$ & 3 & 2 & 1 & 2 & 4 & 3 \\
\hline $\mathrm{Sc}$ & 7 & 11 & 4 & 5 & 3 & 3 \\
\hline V & 5 & 6 & 2 & 6 & 5 & 1 \\
\hline $\mathrm{Ba}$ & 1577 & 1480 & 593 & 1281 & 1597 & 580 \\
\hline $\mathrm{Rb}$ & 91 & 77 & 130 & 96 & 93 & 122 \\
\hline $\mathrm{Sr}$ & 137 & 193 & 34 & 64 & 91 & 33 \\
\hline $\mathrm{Zr}$ & 320 & 363 & 72 & 210 & 170 & 73 \\
\hline Y & 53 & 46 & 35 & 49 & 37 & 35 \\
\hline $\mathrm{Nb}$ & 12.7 & 14.1 & 9.3 & 11.3 & 10.0 & 10.7 \\
\hline $\mathrm{Ga}$ & 20 & 20 & 16 & 19 & 17 & 16 \\
\hline $\mathrm{Cu}$ & 2 & 3 & 0 & 2 & 1 & 0 \\
\hline $\mathrm{Zn}$ & 71 & 84 & 38 & 66 & 61 & 40 \\
\hline $\mathrm{Pb}$ & 15 & 13 & 16 & 15 & 14 & 17 \\
\hline $\mathrm{La}$ & 38 & 36 & 22 & 37 & 33 & 21 \\
\hline $\mathrm{Ce}$ & 74 & 68 & 39 & 78 & 62 & 44 \\
\hline $\mathrm{Th}$ & 8 & 9 & 11 & 9 & 8 & 10 \\
\hline $\mathrm{Nd}$ & 38 & 33 & 17 & 38 & 28 & 19 \\
\hline $\mathrm{U}$ & 4 & 4 & 4 & 5 & 2 & 4 \\
\hline
\end{tabular}


B-3b : ICP-MS results

\begin{tabular}{|c|c|c|c|c|c|c|c|c|}
\hline \multirow{2}{*}{$\begin{array}{l}\text { Sample } \\
\text { ID }\end{array}$} & \multicolumn{3}{|c|}{ DM044 } & \multirow[b]{2}{*}{ DM202 } & \multirow[b]{2}{*}{ DM220 } & \multirow[b]{2}{*}{ DM223 } & \multirow[b]{2}{*}{ DM234 } & \multirow[b]{2}{*}{ DM235 } \\
\hline & DM038 & B & DM048 & & & & & \\
\hline \multirow[t]{2}{*}{ Unit } & B2 & $\mathrm{R} 4$ & R4 & R3 & R3 & R4 & R2 & R2 \\
\hline & \multicolumn{8}{|c|}{ This Study } \\
\hline \multicolumn{9}{|c|}{ ICP-MS - ppm } \\
\hline $\mathrm{La}$ & 11.87 & 33.92 & 42.25 & 45.38 & 41.83 & 61.22 & 40.40 & 40.36 \\
\hline $\mathrm{Ce}$ & 24.74 & 64.53 & 87.46 & 89.53 & 81.12 & 74.31 & 78.94 & 75.52 \\
\hline $\operatorname{Pr}$ & 3.45 & 8.19 & 10.83 & 11.72 & 10.48 & 17.30 & 9.22 & 8.72 \\
\hline $\mathrm{Nd}$ & 14.81 & 31.51 & 42.33 & 45.97 & 41.08 & 67.67 & 33.32 & 32.21 \\
\hline $\mathrm{Sm}$ & 3.75 & 7.05 & 9.28 & 10.57 & 9.32 & 14.83 & 7.03 & 6.57 \\
\hline $\mathrm{Eu}$ & 1.16 & 0.69 & 1.24 & 1.62 & 1.36 & 1.91 & 0.85 & 0.83 \\
\hline $\mathrm{Gd}$ & 3.78 & 7.18 & 8.29 & 9.63 & 8.76 & 11.58 & 6.26 & 5.51 \\
\hline $\mathrm{Tb}$ & 0.64 & 1.30 & 1.33 & 1.61 & 1.55 & 1.93 & 1.09 & 0.94 \\
\hline Dy & 4.15 & 8.40 & 7.61 & 9.99 & 9.79 & 11.10 & 6.77 & 5.78 \\
\hline Но & 0.86 & 1.83 & 1.55 & 2.03 & 2.05 & 2.12 & 1.36 & 1.18 \\
\hline $\mathrm{Er}$ & 2.43 & 5.31 & 4.38 & 5.65 & 5.62 & 5.68 & 3.77 & 3.44 \\
\hline $\mathrm{Tm}$ & 0.34 & 0.80 & 0.69 & 0.84 & 0.87 & 0.85 & 0.57 & 0.54 \\
\hline $\mathrm{Yb}$ & 2.22 & 5.10 & 4.59 & 5.27 & 5.52 & 5.42 & 3.57 & 3.49 \\
\hline $\mathrm{Lu}$ & 0.36 & 0.80 & 0.74 & 0.79 & 0.86 & 0.82 & 0.58 & 0.55 \\
\hline $\mathrm{Ba}$ & 338 & 2798 & 1594 & 1906 & 1362 & 1556 & 1756 & 1733 \\
\hline Th & 0.98 & 9.89 & 8.61 & 8.17 & 7.33 & 8.14 & 8.34 & 8.96 \\
\hline $\mathrm{Nb}$ & 4.88 & 13.04 & 12.77 & 16.28 & 14.19 & 15.06 & 8.71 & 8.95 \\
\hline $\mathrm{Y}$ & 22.39 & 52.35 & 38.17 & 52.04 & 53.19 & 50.30 & 35.28 & 30.57 \\
\hline $\mathrm{Hf}$ & 2.26 & 6.79 & 8.78 & 9.73 & 8.66 & 7.89 & 5.18 & 5.41 \\
\hline $\mathrm{Ta}$ & 0.29 & 1.01 & 0.95 & 1.11 & 0.98 & 1.05 & 0.73 & 0.78 \\
\hline $\mathrm{U}$ & 0.36 & 3.58 & 3.21 & 3.10 & 2.97 & 3.29 & 3.03 & 3.22 \\
\hline $\mathrm{Pb}$ & 2.68 & 1.92 & 2.04 & 14.35 & 13.43 & 15.47 & 16.28 & 14.98 \\
\hline $\mathrm{Rb}$ & 7.20 & 81.80 & 96.93 & 93.47 & 85.61 & 92.45 & 111.27 & 93.96 \\
\hline Cs & 0.27 & 1.35 & 2.37 & 4.37 & 4.33 & 2.88 & 6.15 & 2.42 \\
\hline $\mathrm{Sr}$ & 385 & 10 & 27 & 170 & 135 & 106 & 123 & 95 \\
\hline $\mathrm{Sc}$ & 31.22 & 4.70 & 5.77 & 8.28 & 8.89 & 3.68 & 3.37 & 3.59 \\
\hline $\mathrm{Zr}$ & 88 & 223 & 331 & 389 & 352 & 288 & 175 & 184 \\
\hline
\end{tabular}




\begin{tabular}{|c|c|c|c|c|c|c|c|c|}
\hline \multirow{4}{*}{$\begin{array}{l}\text { Sample } \\
\text { ID }\end{array}$} & & \multicolumn{5}{|c|}{ DM246 } & DM255 & \multirow{4}{*}{$\begin{array}{c}\text { DM255 } \\
\text { B } \\
\text { B1 }\end{array}$} \\
\hline & DM238 & DM240 & DM241 & A & DM247 & DM250 & A & \\
\hline & $\mathrm{R} 4$ & R3 & R3 & $\mathrm{T} 1$ & $\mathrm{R} 1$ & R3 & & \\
\hline & \multicolumn{7}{|c|}{ This Study } & \\
\hline \multicolumn{9}{|c|}{ ICP-MS - ppm } \\
\hline $\mathrm{La}$ & 39.61 & 39.29 & 37.14 & 37.17 & 24.65 & 35.85 & 45.35 & 6.91 \\
\hline $\mathrm{Ce}$ & 82.71 & 75.05 & 73.79 & 76.82 & 48.68 & 70.05 & 97.56 & 15.89 \\
\hline $\operatorname{Pr}$ & 10.46 & 9.89 & 9.23 & 9.92 & 5.49 & 8.68 & 12.60 & 2.30 \\
\hline $\mathrm{Nd}$ & 40.82 & 37.90 & 35.26 & 39.62 & 19.72 & 33.36 & 49.60 & 10.20 \\
\hline Sm & 9.51 & 8.22 & 7.93 & 9.76 & 4.60 & 7.09 & 8.73 & 2.86 \\
\hline $\mathrm{Eu}$ & 1.36 & 1.22 & 1.12 & 1.50 & 0.26 & 1.11 & 2.29 & 0.96 \\
\hline $\mathrm{Gd}$ & 9.01 & 7.81 & 7.24 & 10.07 & 4.68 & 7.07 & 6.27 & 3.37 \\
\hline $\mathrm{Tb}$ & 1.62 & 1.36 & 1.25 & 1.95 & 0.87 & 1.24 & 0.81 & 0.61 \\
\hline Dy & 10.41 & 8.47 & 8.07 & 13.27 & 5.64 & 7.90 & 4.30 & 4.14 \\
\hline Ho & 2.21 & 1.76 & 1.69 & 3.00 & 1.17 & 1.71 & 0.79 & 0.90 \\
\hline $\mathrm{Er}$ & 6.11 & 5.01 & 4.83 & 8.97 & 3.35 & 4.85 & 2.00 & 2.45 \\
\hline $\mathrm{Tm}$ & 0.93 & 0.76 & 0.73 & 1.38 & 0.52 & 0.74 & 0.27 & 0.38 \\
\hline $\mathrm{Yb}$ & 5.92 & 4.73 & 4.64 & 9.15 & 3.35 & 4.68 & 1.64 & 2.26 \\
\hline $\mathrm{Lu}$ & 0.90 & 0.74 & 0.72 & 1.49 & 0.51 & 0.76 & 0.27 & 0.38 \\
\hline $\mathrm{Ba}$ & 1518 & 1364 & 1327 & 1238 & 690 & 1325 & 922 & 231 \\
\hline Th & 7.84 & 7.94 & 7.64 & 6.85 & 9.84 & 7.54 & 3.51 & 0.60 \\
\hline $\mathrm{Nb}$ & 14.91 & 13.69 & 12.92 & 20.39 & 8.94 & 12.08 & 13.54 & 3.76 \\
\hline $\mathrm{Y}$ & 57.38 & 47.27 & 45.55 & 80.25 & 33.47 & 47.78 & 20.86 & 22.53 \\
\hline $\mathrm{Hf}$ & 7.71 & 8.15 & 7.71 & 10.08 & 3.48 & 7.81 & 4.14 & 1.63 \\
\hline Та & 1.10 & 0.98 & 0.95 & 1.25 & 1.03 & 0.87 & 0.72 & 0.23 \\
\hline $\mathrm{U}$ & 3.10 & 3.20 & 3.02 & 3.01 & 3.93 & 3.03 & 1.15 & 0.21 \\
\hline $\mathrm{Pb}$ & 14.43 & 14.10 & 13.67 & 12.54 & 17.35 & 13.65 & 8.65 & 1.34 \\
\hline $\mathrm{Rb}$ & 89.47 & 89.66 & 86.67 & 64.10 & 115.45 & 87.50 & 16.45 & 6.67 \\
\hline Cs & 4.10 & 2.93 & 4.22 & 2.38 & 4.77 & 4.60 & 0.95 & 0.16 \\
\hline $\mathrm{Sr}$ & 111 & 146 & 135 & 38 & 40 & 145 & 1611 & 319 \\
\hline $\mathrm{Sc}$ & 3.63 & 6.47 & 7.08 & 3.93 & 3.41 & 7.01 & 20.29 & 32.68 \\
\hline $\mathrm{Zr}$ & 275 & 321 & 307 & 387 & 87 & 303 & 174 & 60 \\
\hline
\end{tabular}




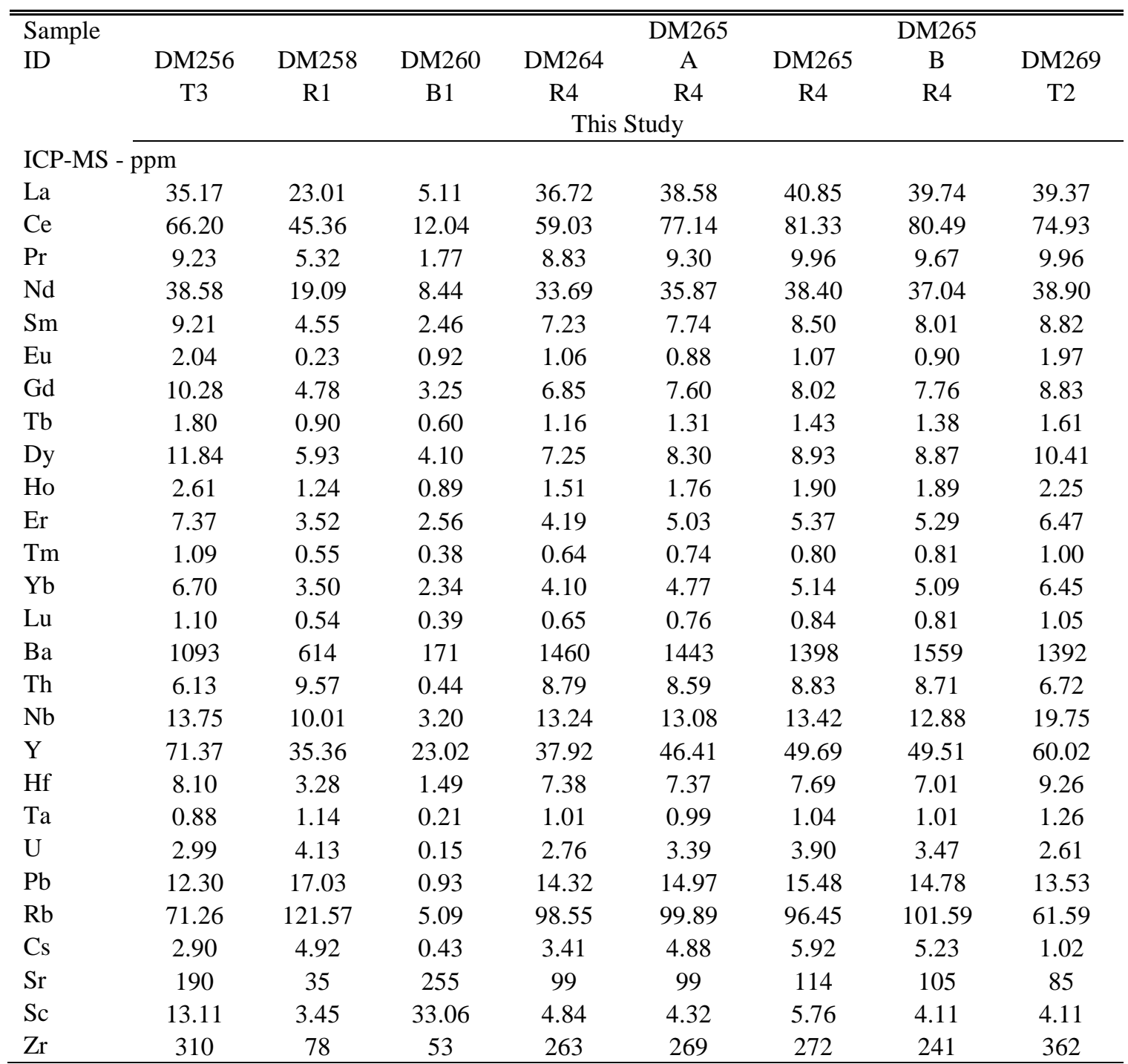




\begin{tabular}{|c|c|c|c|c|c|c|}
\hline Sample ID & $\begin{array}{c}\text { DM273A } \\
\text { R4 } \\
\text { This } \\
\text { Study }\end{array}$ & $\begin{array}{l}\text { DR2 } \\
\text { R3 }\end{array}$ & $\begin{array}{l}\text { DR4 } \\
\text { R1 } \\
\text { Streck }\end{array}$ & $\begin{array}{c}\text { MS-11- } \\
\text { 22DR } \\
\text { R4 }\end{array}$ & $\begin{array}{c}\text { EJ-23A } \\
\text { R2 } \\
\text { Hess }\end{array}$ & $\begin{array}{l}\text { EJ-23B } \\
\text { R1 } \\
\text { 014) }\end{array}$ \\
\hline \multicolumn{7}{|c|}{ ICP-MS - ppm } \\
\hline $\mathrm{La}$ & 39.71 & 35.07 & 23.08 & 40.20 & 36.35 & 22.69 \\
\hline $\mathrm{Ce}$ & 76.76 & 70.32 & 44.84 & 83.81 & 69.29 & 44.39 \\
\hline $\operatorname{Pr}$ & 9.62 & 8.77 & 5.27 & 10.54 & 8.06 & 5.19 \\
\hline $\mathrm{Nd}$ & 37.12 & 34.54 & 19.07 & 39.94 & 29.18 & 18.85 \\
\hline $\mathrm{Sm}$ & 8.21 & 7.79 & 4.59 & 8.67 & 5.98 & 4.53 \\
\hline $\mathrm{Eu}$ & 1.46 & 1.58 & 0.24 & 0.83 & 0.79 & 0.23 \\
\hline Gd & 8.27 & 7.51 & 4.72 & 8.02 & 5.61 & 4.66 \\
\hline $\mathrm{Tb}$ & 1.46 & 1.29 & 0.88 & 1.40 & 0.98 & 0.87 \\
\hline Dy & 9.17 & 8.23 & 5.71 & 8.82 & 6.14 & 5.69 \\
\hline Но & 1.96 & 1.71 & 1.21 & 1.84 & 1.29 & 1.20 \\
\hline $\mathrm{Er}$ & 5.56 & 4.91 & 3.50 & 5.13 & 3.70 & 3.39 \\
\hline $\mathrm{Tm}$ & 0.86 & 0.75 & 0.53 & 0.78 & 0.56 & 0.52 \\
\hline $\mathrm{Yb}$ & 5.46 & 4.78 & 3.42 & 5.01 & 3.61 & 3.36 \\
\hline $\mathrm{Lu}$ & 0.89 & 0.75 & 0.53 & 0.81 & 0.57 & 0.52 \\
\hline $\mathrm{Ba}$ & 1644 & 1523 & 614 & 1323 & 1626 & 589 \\
\hline Th & 8.01 & 6.83 & 9.28 & 8.98 & 8.52 & 9.43 \\
\hline $\mathrm{Nb}$ & 11.98 & 13.76 & 9.50 & 10.91 & 9.61 & 9.49 \\
\hline Y & 52.58 & 45.47 & 34.36 & 48.25 & 35.11 & 33.87 \\
\hline $\mathrm{Hf}$ & 8.10 & 8.80 & 3.17 & 6.37 & 5.14 & 3.19 \\
\hline $\mathrm{Ta}$ & 0.89 & 0.90 & 1.08 & 0.88 & 0.79 & 1.07 \\
\hline $\mathrm{U}$ & 3.13 & 2.73 & 3.97 & 3.50 & 3.11 & 4.00 \\
\hline $\mathrm{Pb}$ & 14.31 & 13.19 & 16.54 & 14.09 & 14.88 & 16.07 \\
\hline $\mathrm{Rb}$ & 88.35 & 77.46 & 130.65 & 99.65 & 93.23 & 122.45 \\
\hline Cs & 3.55 & 3.46 & 5.07 & 4.92 & 3.87 & 6.01 \\
\hline $\mathrm{Sr}$ & 137 & 192 & 34 & 68 & 96 & 37 \\
\hline $\mathrm{Sc}$ & 6.43 & 11.32 & 3.32 & 4.67 & 3.41 & 3.14 \\
\hline $\mathrm{Zr}$ & 323 & 375 & 75 & 216 & 172 & 75 \\
\hline
\end{tabular}




\section{B-3c : Multi-element diagrams}

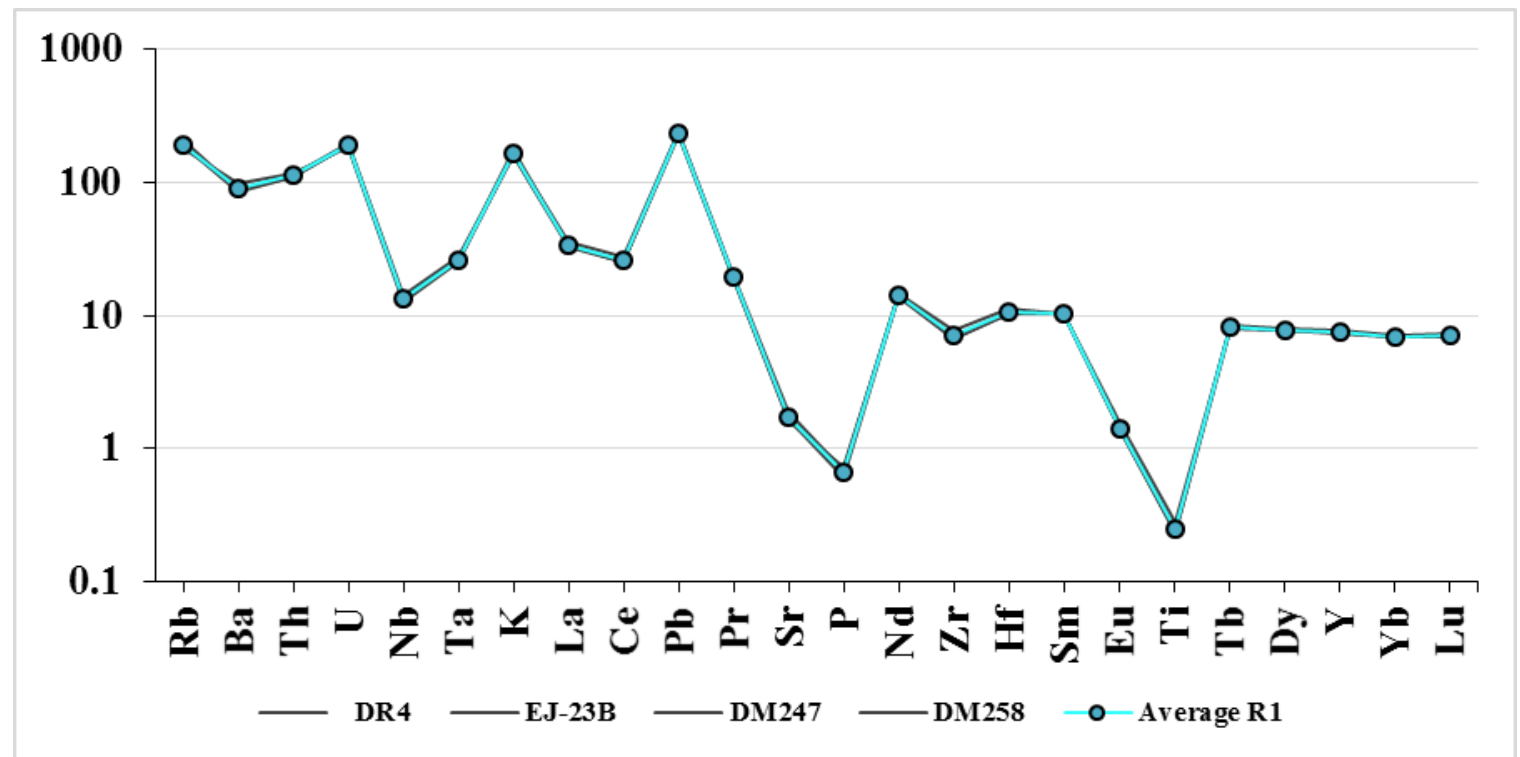

Figure A1: Multi-element diagram of average geochemical group R1 (light blue) in comparison to within group samples (dark gray). Concentrations normalized to mantle values of Sun and McDonough (1989).

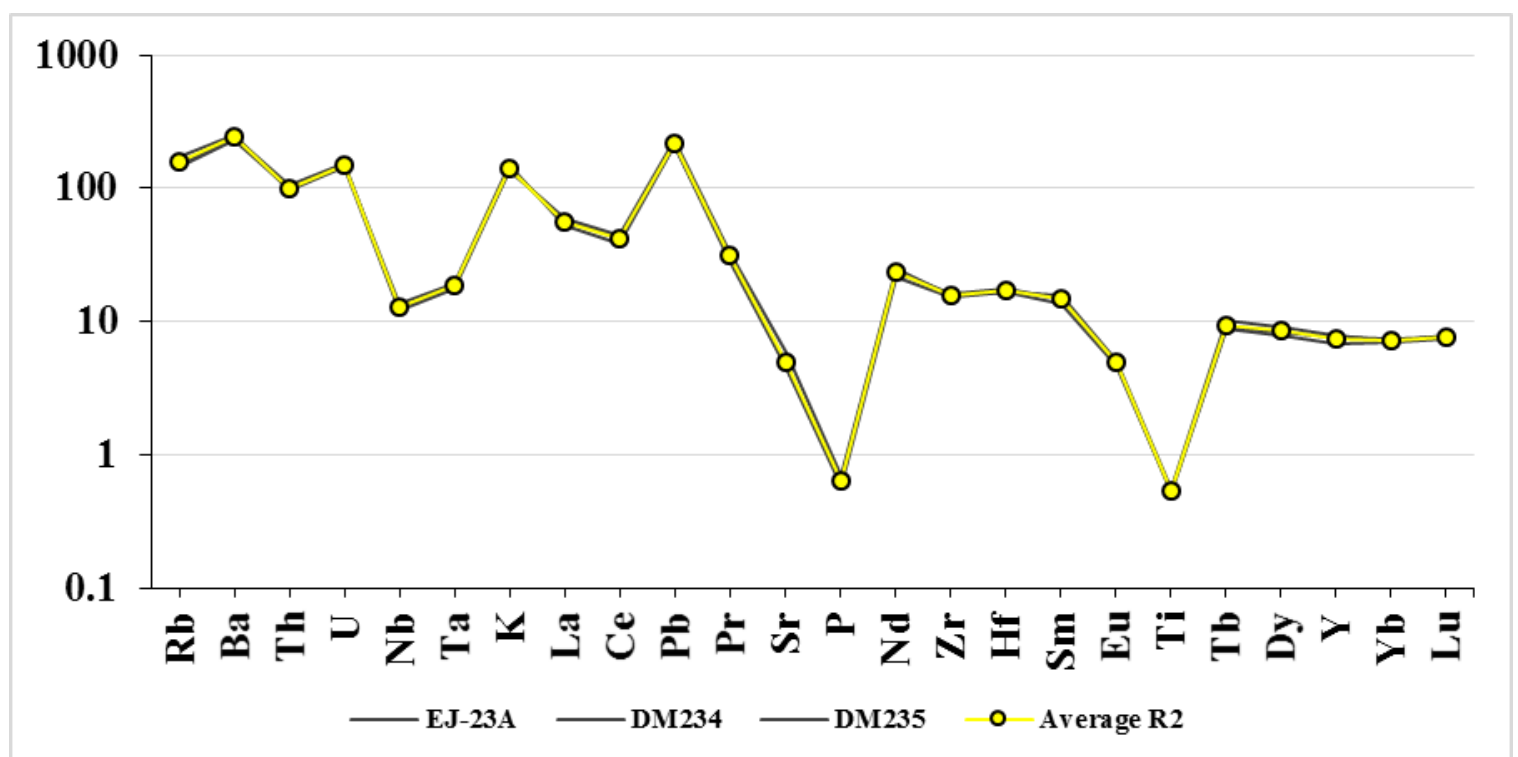

Figure A2: Multi-element diagram of average geochemical group R2 (yellow) in comparison to within group samples (dark gray). Concentrations normalized to mantle values of Sun and McDonough (1989). 


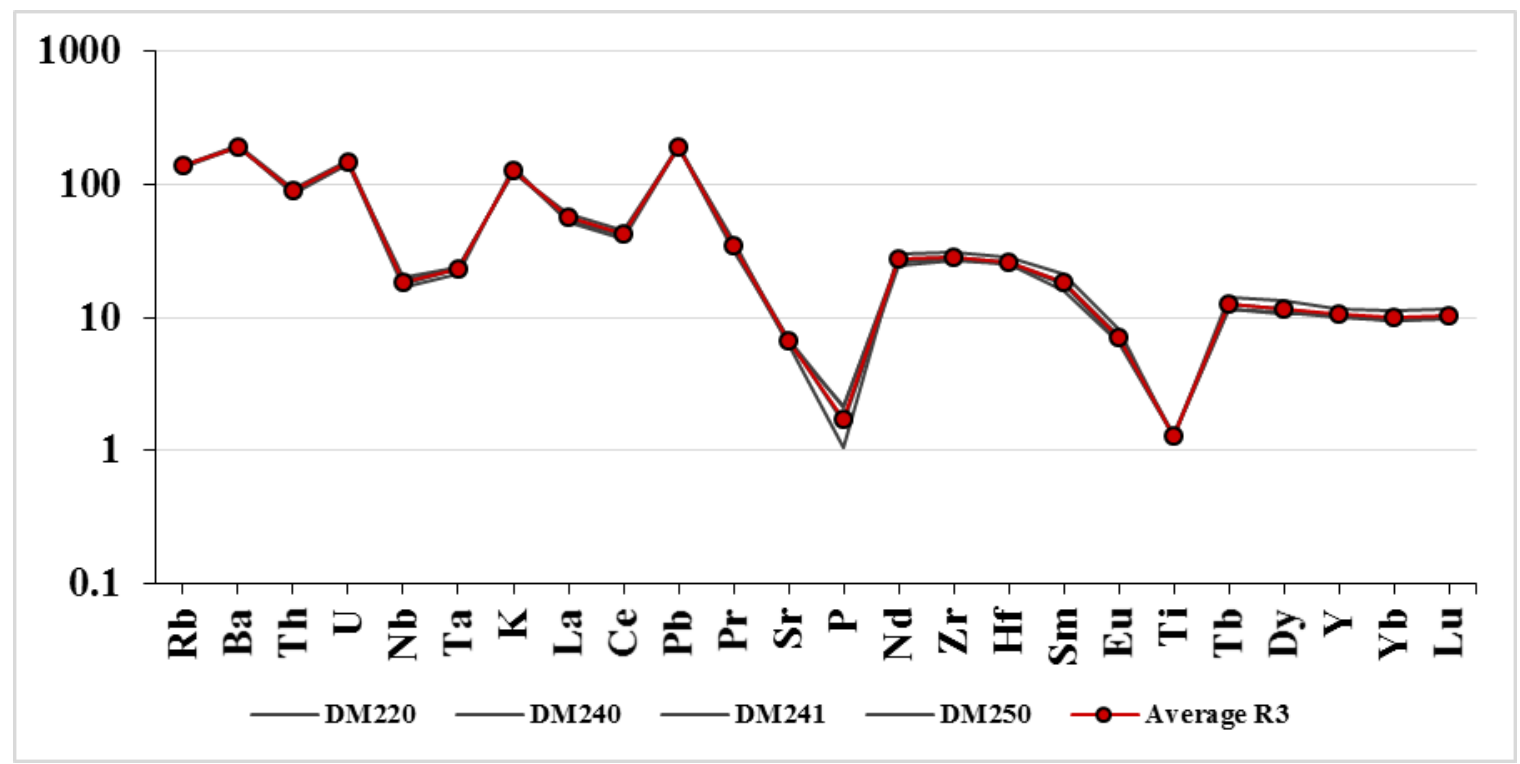

Figure A3: Multi-element diagram of average geochemical group R3 (red) in comparison to within group samples (dark gray). Concentrations normalized to mantle values of Sun and McDonough (1989).

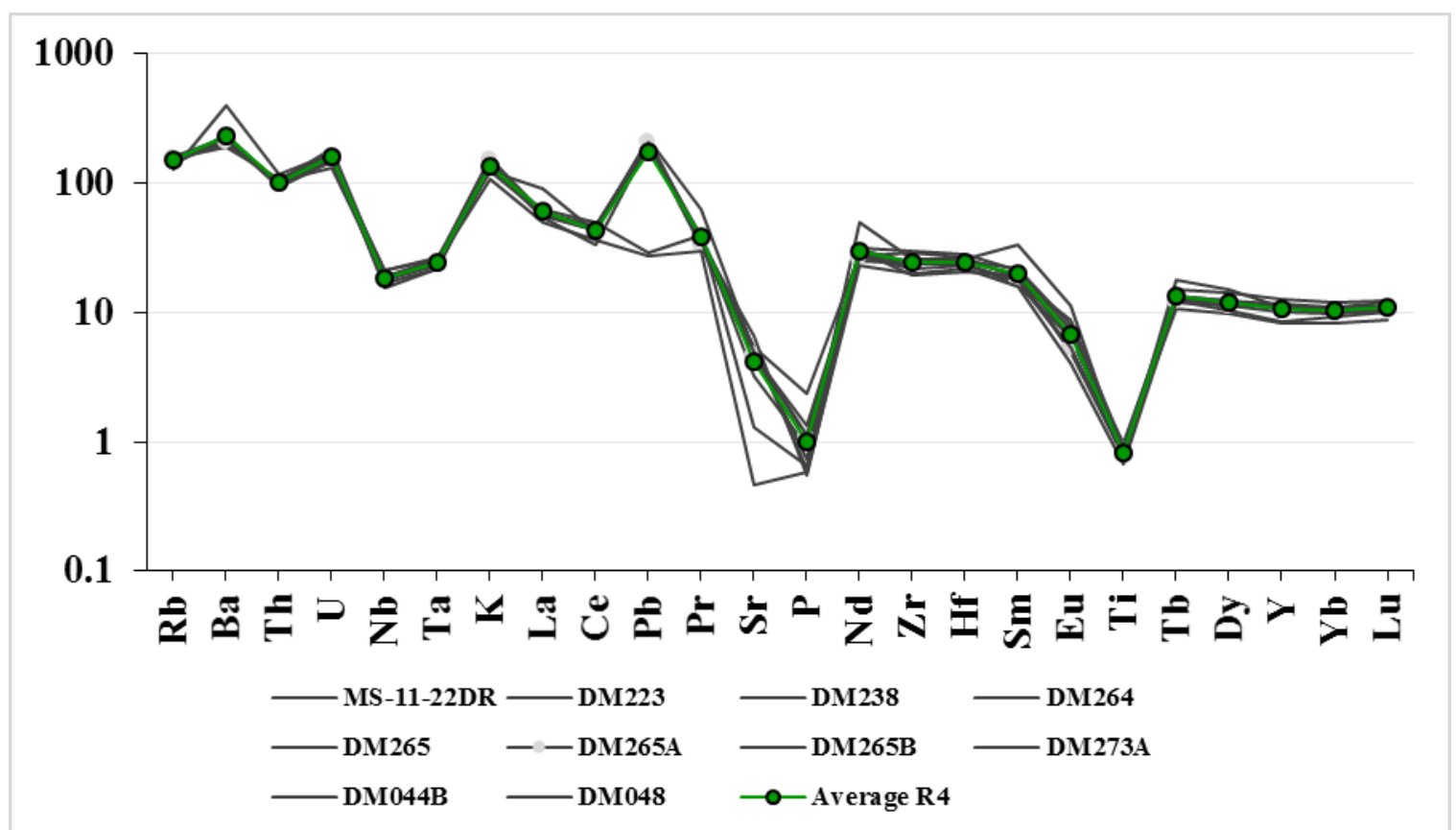

Figure A4: Multi-element diagram of average geochemical group R4 (green) in comparison to within group samples (dark gray). Outlying samples with depleted $\mathrm{Sr}$ and $\mathrm{Pb}$ are samples DM044B and DM048.

Concentrations normalized to mantle values of Sun and McDonough (1989). 